Portland State University

PDXScholar

1993

\title{
Urbanization in a Peripheral Capitalist State: A Guyana Case Study
}

Wazir Ahmad Ishmael

Portland State University

Follow this and additional works at: https://pdxscholar.library.pdx.edu/open_access_etds Let us know how access to this document benefits you.

Recommended Citation

Ishmael, Wazir Ahmad, "Urbanization in a Peripheral Capitalist State: A Guyana Case Study" (1993).

Dissertations and Theses. Paper 1385.

https://doi.org/10.15760/etd.1384

This Dissertation is brought to you for free and open access. It has been accepted for inclusion in Dissertations and Theses by an authorized administrator of PDXScholar. Please contact us if we can make this document more accessible: pdxscholar@pdx.edu. 
URBANIZATION IN A PERIPHERAL CAPITALIST STATE:

A GUYANA CASE STUDY

by

WAZIR AHMAD ISHMAEL

A dissertation submitted in partial fulfillment of the requirements for the degree of

\author{
DOCTOR OF PHILOSOPHY \\ in \\ URBAN STUDIES
}

Portland State University

01993 
TO THE OFFICE OF GRADUATE STUDIES:

The members of the Committee approve the thesis of Wazir Ahmad Ishmael presented November 25, 1992.

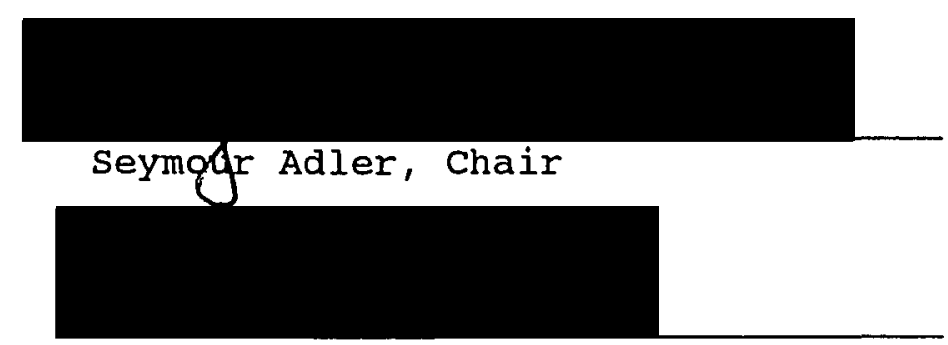

Carl Abbott

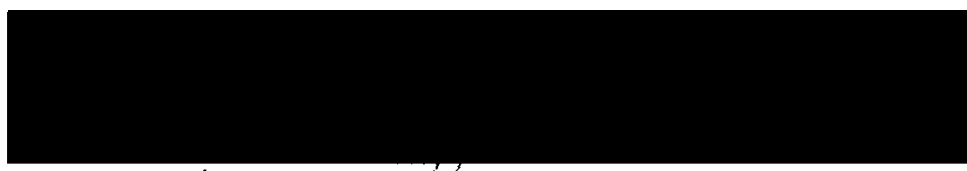

Candice Gouchẹr

Martin Hart-Landsberg

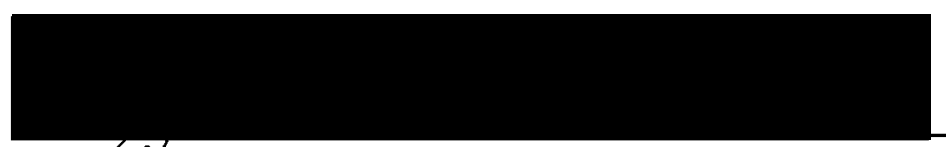

Johranna Brenner

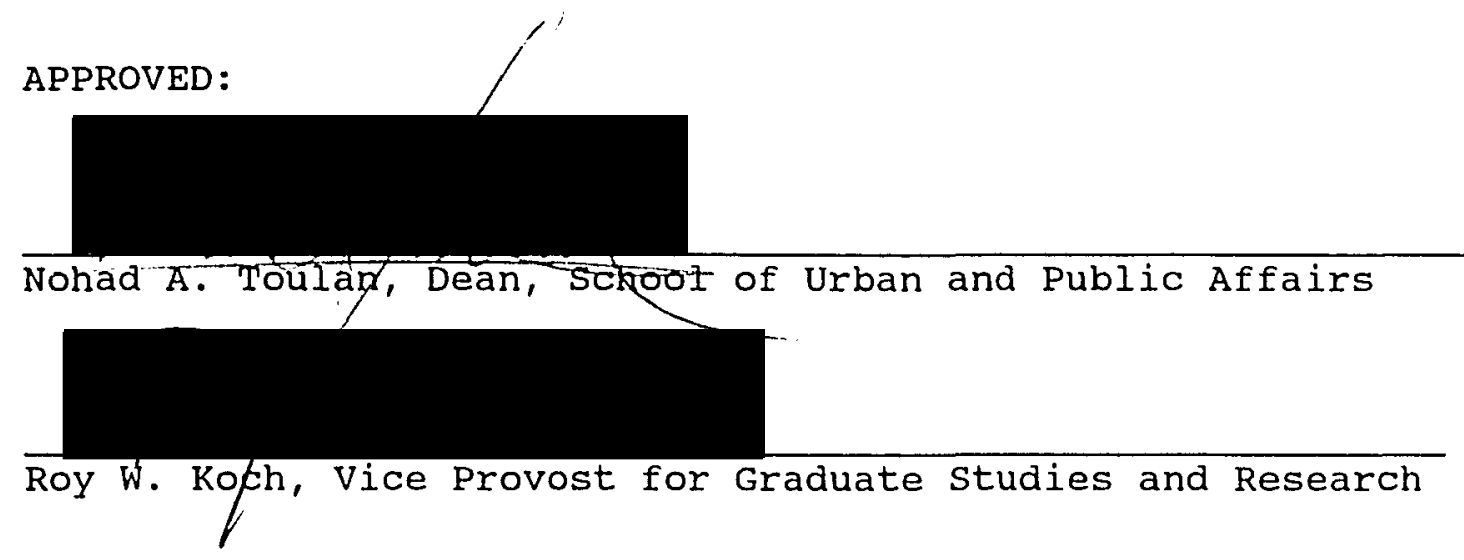


AN ABSTRACT OF THE THESIS OF Wazir Ahmad Ishmael for the Doctor of Philosophy in Urban Studies presented November 25, 1992 .

Title: Urbanization In A Peripheral Capitalist state: A Guyana Case study.

APPROVED BY THE MEMBERS OF THE DISSERTATION COMMITTEE:

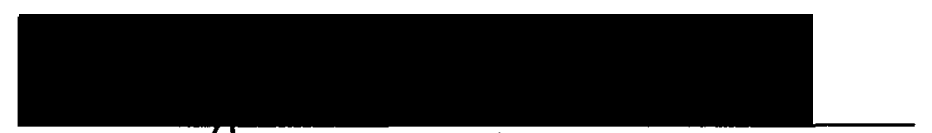

Seymoud Adler, Chair

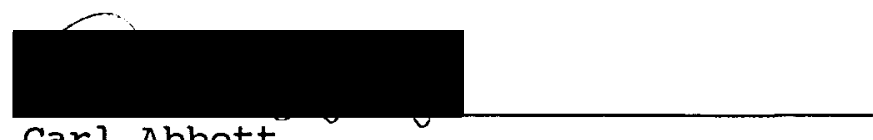

Carl Abbott

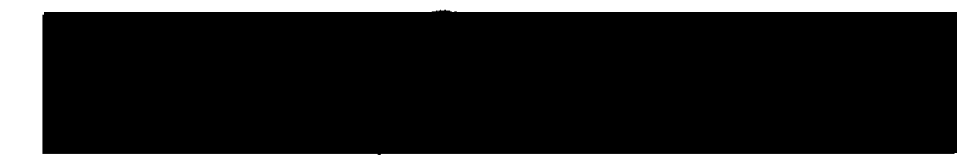

Candice Gouchór

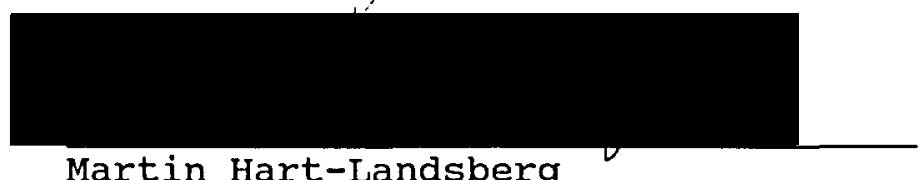

Martin Hart-Landsberg

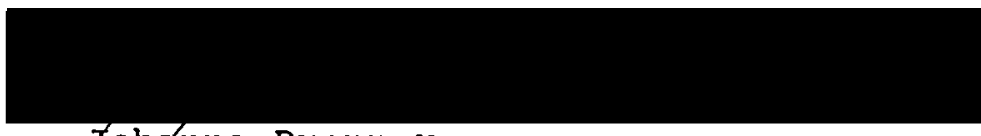

Johanna Brenner

This research proposes to examine the process of urbanization in Guyana, South America. In particular, the objectives of this research are threefold. The first is to 
identify, describe, and evaluate some of the historic and current causes of urban growth and urbanization which have taken place in a peripheral capitalist state that was under the plantation mode and that illustrates a legacy of "uneven development." The second objective is to attempt to assess planning responses, through attempts by the state to formulate policies to deal more effectively with urbanization. And the third objective is to contribute to a dialogue between planning practitioners and dependency/world-system theorists. Although any urbanization process has a variety of endogenous and exogenous variables, the major premise of this study is that the world system affects the political economy of the state and hence its pattern of urban development. That is, urbanization in Guyana can be largely attributed to its colonial legacy after a prolonged period of Dutch, French, and British tutelage, and to the general influence of metropolitan economic dictates.

In surveying the components shaping urbanization, the study discerns outcomes which essentially confirms the expectations of dependency/world-system theory. Following its incorporation into the modern world system, Guyana has reproduced many of the patterns of development that are expected of a dependent peripheral economy.

Core power hegemony led to the stimulation and growth of the port town of Georgetown and the secondary port of New 
Amsterdam. Georgetown, the capital, in particular was used not only to evacuate economic surplus, but also to provide a market for core-manufactured goods.

Whilst dependency/world-system theory allows one to demonstrate how surplus value was extracted from Guyana via the circulation of primary commodities, it failed to adequately address the manner in which labor was utilized and reproduced.

Urbanization in Guyana is contingent not only upon the class struggle, but also ethnic/racial conflict. Throughout the study, the historical evidence has supported the notion that race has been a dominant factor in the internal political economy. Racial considerations have been most important in determining legislation, the allocation of economic surplus, planning, and development policies which have impacted urbanization.

Guyana today appears to conform to the postulates of dependent urbanization. Among the observed characteristics of the urban structure are urban primacy, unemployment and underemployment, a burgeoning informal sector, intra-urban inequality, shanty towns and squatter settlements, and retardation in rural areas. These dependent urbanization features have also been accompanied by a number of conditions that appear to be common to all countries which have experienced dependent development. Within the economic structure, there is an overwhelming primary export 
orientation with product elaboration in the core, low rates of GNP and per capita incomes, a stunted manufacturing sector, a lack of diversification, low-productivity and lowwage labor, excessive dependence, a deepening divergence between what is consumed and what is produced, and the absence of an internal dynamic and coherence. Within the political and social structure, the study has noted perceived racial and ethnic divisions, a high degree of social segmentation, residential separation along racial lines, profound inequalities, instability, bureaucratism, and authoritarian tendencies.

Finally, this study of the Guyana experience demonstrates that dependency/world-system theory can be a powerful heuristic tool in organizing, understanding, and explaining the nature of the urbanization process in a peripheral capitalist state. The research further suggests that when the theory is supplemented with a realist perspective that places a premium on internal dynamics, the dialectical relationship between external and internal forces will ensure a more complete analysis of urbanization in peripheral social formations. 
DEDICATION

This thesis is dedicated to my wife, parents, family, and friends, and to all those who must daily confront capital and racism on the periphery. 


\section{ACKNOWLEDGEMENTS}

This has truly been a cooperative effort. I wish to express my sincere appreciation to several individuals and institutions in the core (United states) and the periphery (Guyana), without whom this work would not have been possible.

In the core: I am deeply indebted to Professors Sy Adler, Carl Abbott, Johanna Brenner, Candice Goucher, and Martin Hart-Landsberg for their invaluable advice, insightful comments, kindness, and moral support.

I would like to thank the School of Urban and Public Affairs for providing me with research and teaching assistantships throughout my academic studies, and granting the Maurie clark Fellowship for the final year of my dissertation.

Mention must also be made of members of the library staff at Portland State University, the University of Washington, Stanford University, and the University of Miami, who never lost their patience despite my numerous requests for materials.

In the periphery: I would like to express my 
gratitude to the staff at the National Archives, the University of Guyana Library, the New Amsterdam Library, the State Planning Secretariat, the Statistical Bureau, the Georgetown city Council, and the New Amsterdam Town Council. Special appreciation goes to my immediate and extended family in Guyana, the United States, and the United Kingdom. I owe them everything. Finally, I want to express a very special thanks to my long-suffering wife, Yasmin, for her help in typing this behemoth, and for her support, patience, and understanding on a project that took far longer than anticipated. 
TABLE OF CONTENTS

PAGE

ACKNOWLEDGEMENTS $\ldots \ldots \ldots \ldots \ldots \ldots \ldots \ldots \ldots \ldots \ldots \ldots \ldots \ldots \ldots$

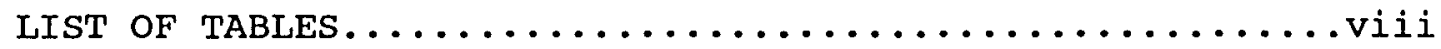

LIST CF FIGURES..........................

CHAPTER

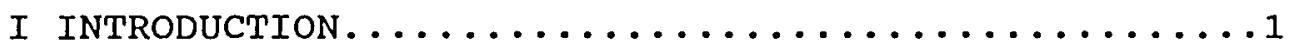

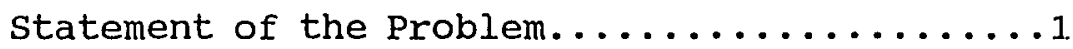

Importance of the study...............

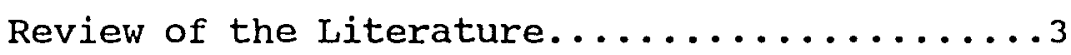

Modernization Theory...............4

Dependency/World-System Theory........11 Dependency/World-System Theory and

Dependent Urbanization: A Synthesis.....23

Methodology......................29

Definitions.....................40

Evaluation of Sources...............41

Organization of the study............45

II EARLY COLONIALISM AND SLAVE PLANTATION SOCIETY

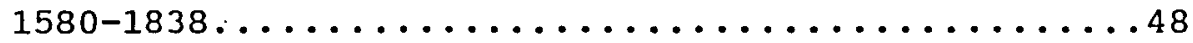

Geographical Context..............48

Global Linkages.................... 55

Industrial structure..............74 


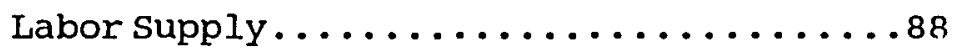

Immigration. .................. 92

Demography....................... 94

Infrastructure and Urban Development......102

Land Use. . . . . . . . . . . . . . . 131

Political and Social structure.......138

Summary......................... 158

III POST-EMANCIPATION AND INDENTURESHIP 1838-1917...161

Global Linkages.........................

Industrial structure............... 168

Labor Supply. . . . . . . . . . . . . 172

Village Movement. . . . . . . . . . . . 177

Immigration. . . . . . . . . . . . . . 187

Demography....................... 197

Infrastructure and Urban Development......218

Land Use. . . . . . . . . . . . . 241

Political and Social structure.......254

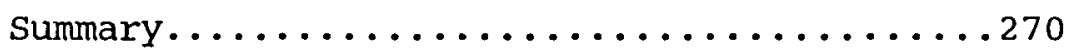

IV TWENTIETH CENTURY COLONIAL RULE 1917-1966......273

Global Linkages....................273

Industrial structure.....................

Labor Supply . . . . . . . . . . . 292

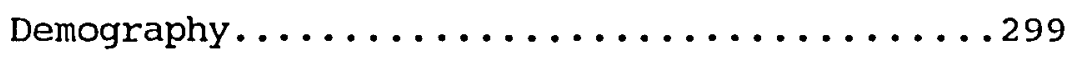

Infrastructure and Urban Development.......313

Land Use. . . . . . . . . . . . . . . 333

Political and Social structure........338

summary ..............................

V POST-INDEPENDENCE 1966-PRESENT.................. 362

Global Linkages......................... 362 
Industrial structure................... 374

Labor Supply..................... 383

Demography.............................. 391

Infrastructure and Urban Development......412

Land Use. . . . . . . . . . . . . . 444 Political and Social structure......4454

Summary $\ldots \ldots \ldots \ldots \ldots \ldots \ldots \ldots \ldots \ldots \ldots \ldots$

vi concLusion............................. 475

SELECTED BIBLIOGRAPHY...................... 489 APPENDICES

A MAJOR GOALS/OBJECTIVES OF THE 1966-1972 DEVELOPMENT PROGRAM............................ 510

B MAJOR GOALS/OBJECTIVES OF THE 1980 GEORGETOWN PLAN................................ 513 


\section{LIST OF TABLES}

TABLE

PAGE

I Comparative Production of Sugar, Coffee and cotton, Essequibo and Demerara 1793-1798............79

II Comparative Production of Sugar, Coffee and cotton, Essequibo, Demerara and Berbice 1797-1802 .....83

III Comparative Production of Sugar, Coffee and Cotton, Essequibo and Demerara, 1810-1824 (Millions of

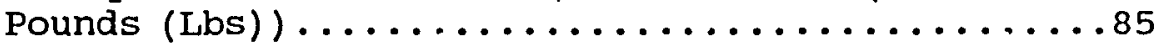

IV Comparative Production of Sugar, Coffee and cotton, Guyana 1833-1838 (Millions of Pounds (Lbs)) ....87

V Guyanese Immigration $1835-1838 \ldots \ldots \ldots \ldots . \ldots . \ldots 94$

VI Population Distribution $1831 \ldots \ldots \ldots \ldots 10 \ldots \ldots \ldots$

VII Decline in Sugar-Yields on Interior Lands. . . . . 105

VIII Comparative Production of Sugar and Coffee

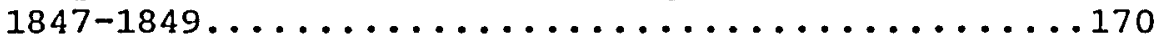

IX Guyanese Indentured Immigration $1835-1917 \ldots \ldots . .195$

X Racial Composition of the Population 1851.....197

XI Population Distribution 1851-1911...........198

XII Industrial Establishments $1943 \ldots \ldots \ldots \ldots 287$

XIII Selected Sectoral Contribution to GDP 1960....291

XIV Sugar Estate Employment 1953-1966...........297

XV Sectoral Distribution of Labor Force 1946-1965..298

XVI Population Distribution...................... 300

XVII Gender Ratio $1881-1931 \ldots \ldots \ldots \ldots \ldots \ldots \ldots$ 
XVIII Death Rates of Indians and Africans 1936-1960_..308

XIX Birth Rates of Indians and Africans 1936-1960..309

XX Export Earnings of Sugar, Rice, Bauxite 1966-1989

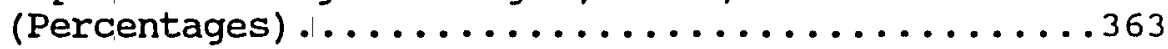

XXI Export Earnings of Sugar, Rice, Bauxite 1966-1989

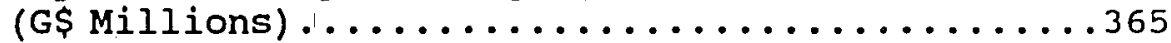

XXII Exports and Imports with selected Major Trading Partners 1964-1976 (Percentages)...........366

XXIII Unit Values of Major Exports 1970-1981

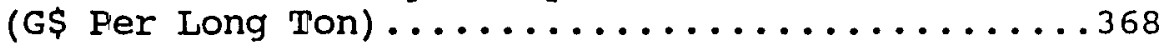

XXIV Balance of Visible Trade 1970-1989

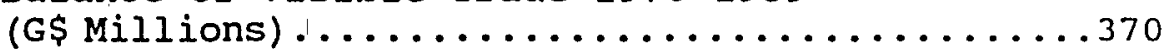

XXV Export of Sugar, Rice, Bauxite, 1980-1989

(Thousands of $\mid$ Long Tons).....................

XXVI Selected sectoral contribution to GDP 1966-1989

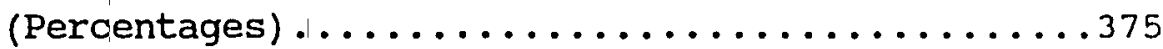

XXVII Production of Gold and Diamonds 1981-1989......377

XXVIII Production of Sugar, Rice, Bauxite 1970-1989

(Thousands of $\mid$ Long Tons) ........................

XXIX Sectoral Distribution of Labor Force 1965-1980..384

XXX Sugar Estate Employment 1966-1970...........385

XXXI Occupational status of the Economically Active

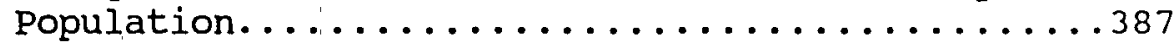

XXXII Sugar Estate Employment 1970-1982..........388

XXXIII Population Distribution 1960-1980............392

XXXIV Gender Ratio $1960-1989 \ldots \ldots \ldots \ldots \ldots . \ldots . \ldots 393$

XXXV Racial Distribution of the Population 1970....396

XXXVI Racial Composition of the Population 1960-1986..397

XXXVII Components of Population Change 1970-1980.....399

XXXVIII Areas of Residence and Birthplaces of Population

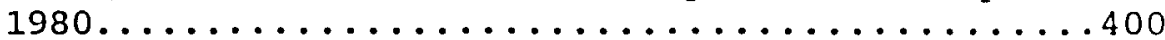


XXXIX Place of Birth and Area of Residence of Population

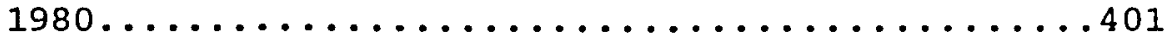

XL Fertility Rates by Race for Female Population

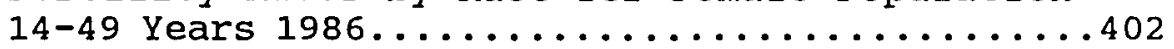

XLI Emigration by Age Group, Gender and Year of Departure 1981-1986..................404

XLII Urban and Rural Population Distribution by Region

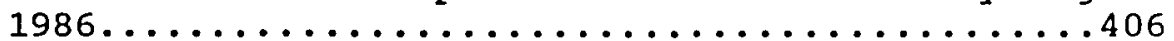

XLIII Population Born in Guyana by Region of Birth:

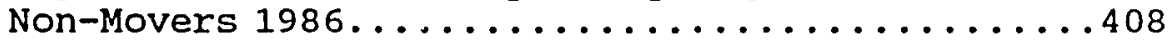

XIIV Population Born in Guyana by Region of Residence: In-Migrants $1986 \ldots \ldots \ldots \ldots \ldots \ldots \ldots . \ldots \ldots$

XLV Racial Distribution of Population by Region

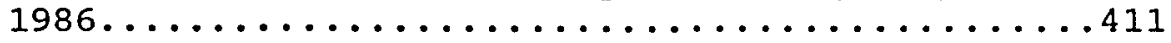

XLVI Allocation of Development Expenditure 1966-1972 Development Plan (G\$ Millions)...........414

XLVII Allocation of Development Expenditure 1972-1976 Development Plan (G\$ Millions)...........420

XLVIII Allocation of Development Expenditure 1978-1981

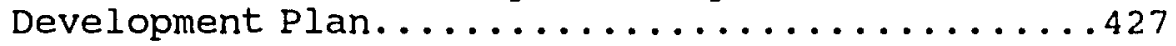

XLIX Central Government Capital Expenditure by Sectors 1978-1981 (G\$ Millions) ...............429

I Regional Allocation of Capital Expenditure 1979 (Percentage) ....................430

Central Government Capital Expenditure by Sectors

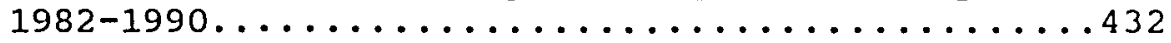

LIII Land Settlement Schemes $-1973 \ldots \ldots \ldots \ldots \ldots 48$ 


\section{LIST OF FIGURES}

$\begin{array}{ll}\text { FIGURE } & \text { PAGE }\end{array}$

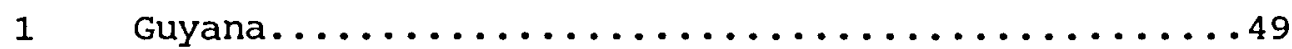

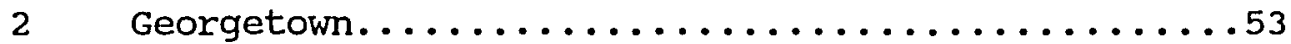

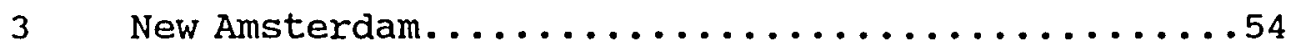

4 Administrative Regions of Guyana...........405

5 Administrative Reegions $1973 \ldots \ldots \ldots \ldots \ldots \ldots$......... 431 


\section{CHAPTER I}

INTRODUCTION

\section{STATEMENT OF THE PROBLEM}

This research proposes to examine the process of urbanization in Guyana, South America. In particular, the objectives of this research are threefold. The first is to identify, describe, and evaluate some of the historic and current causes of urban growth and urbanization which have taken place in a peripheral capitalist state that was under the plantation mode of socioeconomic organization and that illustrates a legacy of "uneven development." The second objective is to attempt to assess planning responses, through attempts by the state to formulate policies and create institutions to deal more effectively with urbanization and urban growth. And the third objective is to contribute to a dialogue between urban and regional planning practitioners and dependency/world-system theorists. Although any urbanization process has a variety of endogenous and exogenous variables, the major premise of this study is that the world system affects the political 
economy of the state and hence its pattern of urban development. That is, urbanization in Guyana can be largely attributed to its colonial legacy after a prolonged period of Dutch, French, and British tutelage, and to the general influence of metropolitan economic dictates.

IMPORTANCE OF THE STUDY

Since the aftermath of the second World war, much progress has been made in elucidating the components behind urban growth and urbanization, especially the patterns now visible the world over. This has been due largely to a problem-oriented, analytical approach to urban studies. However, what has been said of and for urbanization in other developing areas may not be relevant to Guyanese society. Consequently, there is an overriding need to undertake an in-depth historical case study. This is especially critical, for there has been a seeming neglect of the study of urbanization in the Commonwealth Caribbean in general. 1 Certainly there has been a paucity of published material; most other developing regions have been covered in some detail in the literature, but studies on urbanization in the Caribbean are still woefully lacking. A computerized literature search conducted on August 18, 1989, and

1 Although it is located on the northeast coast of South America, Guyana is usually included as part of the Anglophone Caribbean, with whom it shares a common social, cultural, economic structure, and historical experience. 
utilizing a variety of databases (including Sociological Abstracts, Public Affairs Information Bulletin (PAIS), and Dissertation Abstracts) failed to uncover even a single source that was devoted to the topic. This will therefore be the first detailed study of urbanization in the country. Furthermore, I believe that it is imperative that development planners and dependency/world-system theorists begin to communicate with each other. Unfortunately, development planners in general have chosen to ignore sociopolitical variables and have paid the price with a legacy of failure. On the other hand, dependency/worldsystem researchers, whilst elucidating a clear conception of the urbanization process, have dismissed urban development planners, believing them to be aligned with the ruling class and employing the tools of planning against the interests of the working class. Consequently, over the years they have provided little guidance to planning practitioners. certainly the clamor for socialist revolution and "selective closure" indicates an ignorance of the spatial problematic. The main point here is that structural reforms must meld with spatial-allocative planning if any desirable social change is to be achieved in the developing countries.

\section{REVIEW OF THE LITERATURE}

As with any case study, the present one is written in the context of the literature. The aim here is to provide a 
general picture of the existing literature on urbanization. Despite the fact that there is no universal theory of urbanization, the social science literature is replete with general statements of a historical disposition which attempt to describe and/or explain the causes and effects of the urbanization process. This literature, though diverse, falls under the ambit of two competing "theories" modernization and dependency/world-system.

\section{Modernization Theory}

The historical: antecedents of modernization theory stem from the works of sociologists such as Compte, Maine, Spencer, Toennies, Durkheim, Weber, Redfield, et al. These scholars speculated that all social phenomena were the product of social evolution. That is, societies are said to move along a linear continuum, from "traditional" to "modern", from a "prïmitive, undifferentiated and pre-rational social entity (Gemeinschaft) to a modern, differentiated and bureaucratically rational social entity (Gesellschaft)" (Rimmer and Forbes, 1982:199). In the 1950s and 1960s, theorists who subscribed to the evolutionary model of social change came to dominate development and urbanization research. The theory of modernization was widely discussed by a variety of social theorists, including political scientists, sociologists, and to some extent economists. Applying an inductive approach, this perspective argued quite optimistically that developing 
countries were charting a course already undertaken by Western Europe and North America. Development, and its concomitant urbanization, resulted exclusively from endogenous conditions, be they social-psychological or structural factors.

Social-psychological. In the mid-twentieth century, more emphasis than in the past (e.g., the works of Weber, Durkheim, and Marx) was centered on social-psychological variables as integral factors in the development process. The personality of the individual abruptly became the most important source of modern economic growth. Drawing from Schumpeter (1934), who firmly ensconced the entrepreneur at the core of his "theory of economic development," Everett Hagen (1962) posited the view that development is dependent on "innovative personalities." These personalities (entrepreneurs) come disproportionately from "blocked minorities", who are prevented from rising to conventional sources of power in traditional societies and thus are driven to become wealthy through entrepreneurship. McClelland (1961), also exploring causal connections that give rise to entrepreneurship and socioeconomic change, proposed the concept of "need for achievement" ("n-achievement"). He suggested that societies with large numbers of their populace who are desirous of "getting ahead" will experience economic development. In 1974, Inkeles and Smith, in a massive study that included the 
countries of Argentina, Bangladesh, Chile, India, Israel, and Nigeria, provided corroborative empirical evidence for the social-psychological perspective. The authors found that modern individuals possessed remarkably similar personality traits across countries and that underdevelopment did not necessarily arise from structural problems but from the attitudes and values of citizens. Industrialization as the impetus to economic growth, Inkeles and Smith maintain, can be achieved with relative ease in the developing world (1974:313-314). Once capital-intensive technologies are available, developing countries will be on the road to modernity; the only major obstacle is "becoming modern in spirit" (1974:315).

Structural Perspective. Whilst the socialpsychological perspective of modernization theory has received a modicum of attention, much of the focus has been on the structural component. The structuralist modernization approach is perhaps best exemplified in the work of walter Rostow (1962). In his partially titled "non-communist manifesto," Rostow presented the concept of "stages of economic growth" through which all nations must pass in the transition from underdevelopment to industrialization. According to Rostow (1962:4):

...it is possible to identify all societies, in their economic dimensions, as lying within one of five categories: the traditional society, the preconditions for take-off, the take-off, the drive to maturity, and the age of high mass consumption. 
It was Rostow's goal, of course, to formulate a "gradual non revolutionary model of development based on a belief in progress, rationality and mechanization or industrialization" (Rimmer and Forbes, 1982:200). The theory was eminently suited to the times. After all, it provided an alternative ideology to counter-insurgents during the cold war of the 1950s and 1960s (Mehmet, 1978; Rimmer and Forbes, 1982). Furthermore, it drew nourishment from the success of the American-backed Marshall plan. Reasoning was that if Europe could recover from the devastation of the second World War and modernize its economy within a short period of time, it was entirely feasible to expect the developing world to do the same for their "devastated" economies (Todaro, 1985). As is customary to those in the modernization school, the belief was propagated that the "tricks" to economic growth can be accomplished with relatively little effort. However, unlike those who stress the social-psychological component, structuralists are concerned with "vicious circle" arguments, in which low income leads to low savings, low savings to low investment, low investment to low productivity, low productivity to low income, and so on. Breaking the "circle" can be achieved by injections of foreign aid and/or private foreign investment. Thus, Browett (1980:61) notes:

...economic growth and development in less developed areas will eventually be achieved 
through the transmission of growth impulses... from the more developed areas via aid programmes, financial institutions, trade and multinational corporations. Hence, increasing interaction and integration between less and more developed areas will, at some stage, lead to the onset of development in the former areas.

Implicit in the theory is the presumption that developing countries must be incorporated within the capitalist system if they are to improve their standards of living. They must follow the western model, in which industrialization, urbanization, capital intensive technology, and representative democracy are seen to be indispensable to socioeconomic development. Urbanization is especially important to "traditional societies," since the growth of cities provided the impetus towards modernization. Urban areas are held to be modern enclaves whose gradual expansion and spread effects will eventually trickle down and raise the country to a higher level of development. Disparities between population groups in rural and urban areas, problems posed by urbanization, etc., were simply teething problems and were expected to disappear as developing nations blazed their way to modernity. Ergo, urbanization should be encouraged (Reissman, 1964; Berliner, 1977).

A great deal of criticism has been levelled at the modernization perspective. Theoretical objections have become so familiar that Bach $(1980: 290)$ considers them to be "unmercifully redundant." Nevertheless, in the same 
paragraph, he continues to list a number of the perspective's drawbacks. In deference to Bach, I will proceed in a similar fashion. A first objection to modernization theory is its lack of historical specificity (Mabogunje, 1981; Skocpol, 1977; Slater, 1986; Valenzuela and Valenzuela, 1978). It is Eurocentric and falls into the trap of propounding an image of universal development without considering the historical reality of Third World nation states. Second, the analysis tends to be superficial, based on an idealized ahistorical and nonmaterialist ideology (Skocpol, 1977; Slater, 1986). Third, its simplistic assumptions failed to provide an "adequate explanatory framework for examining city-countryside rélations... and consequently key processes such as changes in the territorial division and socialization of labor could not be identified and comprehended" (Slater, 1986). Fourth, the perspective is devoid of an analysis of class. Third World societies are expected to "develop" in a nonconflictual and consensual manner. The inherent contradictions often associated with capitalism are expected to be rather benign (Mabogunje, 1981). Finally, and perhaps most importantly, the empirical evidence gathered over the last thirty years does not seem to square with the theory (Smith, 1985; Light, 1983; McGee, 1971; Slater, 1974 ; Santos, 1979; Nemeth and Smith, 1985; Smith and Nemeth 1986;). A closer examination of the nature of the 
urbanization process revealed that "urbanization, industrialization and modernization are at best unreliable expressions of each other and should not be confused" (Smailes, 1975:4). In most developing countries, the three processes simply did not parallel each other. As Abu-Lughod and Hay (1977:6) observe:

Earlier it was believed that such high rates of urbanization were healthy, since they indicated economic growth and progress. It was assumed that industrialization and urbanization went together. The fallacies of this perspective have now been amply exposed. For while the gap between levels of urbanization... of the developed and developing world has been closing rapidly, the gap between their levels of economic prosperity...has grown progressively wider at the same time. This more than any other anomaly in the field, has forced a reconsideration of the theory of economic development (modernization)... and the role of cities in the process of industrialization and economic growth.

Pursuing this issue further, Light (1983) discusses a number of ways in which the urbanization process now taking place in the developing world differs from the historical experience of the West: 1) in the developing countries, the pace of urban growth is rising much more quickly than it did during the peak industrializing years of the so-called advanced nations; 2) the gains in urban population have not occurred alongside increases in industrial production; and 3) regional development has been more unbalanced in the developing world than it was in the West. 
Dependency/World-System Theory

Dependency theory encapsulates a paradigm rather than a specific theory. Substantially a post-World War II Latin American construct, early articulation stem largely from the writings of sociologists and economists in Brazil, Chile, Mexico, and Peru. A list of notables would include: Fernando Cardoso, Gonzalez Casanova, Theotonio Dos Santos, Enzo Faletto, Andre Gunder Frank, Celso Furtado, Gino Germani, Helio Jaguaribe, James Petras, Osvaldo Sunkel, and Francisco Weffort. Although there was little genuine consensus among these authors, all were clearly disenchanted with the non-Marxist stages of growth and modernization theories, which were in vogue at the time. The dependentistas, as they became known, therefore sought to directly challenge this dominant perspective.

Perhaps it was inevitable that dependency theory should have received its intellectual awakening in Latin America, rather than elsewhere in the developing world. Social scientists on the continent/ were confronted with independent countries, which possessed abundant natural resources and reasonably trained work forces but which remained underdeveloped. In the absence of any obstacles on which to cast the blame, they felt it necessary to concentrate on the underlying social forces. Much of the early dependency formulations have|been attributed to the work of Gunder Frank $(1967,1969,1972)$. His classic 
text "Capitalism and Underdevelopment in Latin America" was the first significant dependency publication to reach Western audiences. In this publication, Frank laid out what was for many years the standard dependency approach to the theory of underdevelopment.

The Development of Underdevelopment. Frank (1969:4) contended that underdevelopment is not an original state, because "the now developed countries were never underdeveloped, though they may have been undeveloped." It is the structure of the capitalist world economy that has influenced the "development of underdevelopment" in the developing nations (Frank, 1967, 1969). The process of underdevelopment commenced when European countries began to penetrate the social and economic structures of the Third World during the mercantilist and early capitalist expansionist phases. Ironically, underdevelopment is created through capitalism, the very mode of production which was responsible for the development of the nowindustrialized nations. Thus, development and underdevelopment are the result of the same process, or two sides of the same coin. Or as Hermassi (1978:249) puts it, they are "opposite phases of the same historical process." The world, according to Frank (1969:128), is dominated by a "single world embracing capitalist system" that has incorporated and integrated all peoples. These people are linked by an economic process whereby national and regional 
metropolises exploit their economic satellites. This is accomplished through a chain of exploitative relations that extracts surplus towards the center by a series of metropolis-satellite links. This basic dependent structure has created an exchange or transfer of resources that has distorted and hindered the growth of the periphery, whilst enabling the center to accumulate and prosper. Frank rejected the modernizationists' idea that economic development in the Third World can be accomplished within a peripheral capitalist mode of production. External market constraints have created an international division of labor that allows core countries to determine terms of exchange. Peripheral countries, therefore, have little or no chance of attaining mobility within the system. The choice is stark "stagnation or socialist revolution" (Ehrensaft, 1976:61).

A number of critiques have been launched against Frank's early formulation of the underdevelopment thesis, including criticisms from those who are associated with the evolution of the dependency perspective. Perhaps the most vitriolic assault was launched by Laclau (1971), who disputed Frank's generalization that all modes of production were capitalist in the modern world. The notion that Latin America has been a capitalist society since the beginning of the sixteenth century is erroneous and poses a number of theoretical problems for Laclau, since it seemingly contradicts Marx's historical analysis of the times. Much 
of the problem, asserts Laclau, stems from Frank's inaccurate definition of capitalism. Frank deviates from Marxist interpretations by stressing exchange and commercial relationships, rather than means of production. In particular, Frank confuses participation in the global capitalist economic system with the dominance of the capitalist mode of production in Latin America.

Analysts were also concerned that Frank's argument was rather static, leading to "stagnationism" without a proper appreciation of the varying levels of relations of exploitation between the Third World and those in the center. By arbitrarily dividing the world into core and periphery or metropolis and satellite, Frank obfuscated what was essentially a more diversified global economy. The above criticisms are not without merit. However, in defense of Frank, I must state that he has continued to respond to the critics and has altered a good deal of his thinking since 1967. Perhaps Foster-Carter (1976:176) most aptly sums up Frank's contribution when he states: "what is in danger of being forgotten is that it was only because of Frank that we can supersede him." Plantation Dependency. Dependency theorists in the Caribbean have analyzed development and underdevelopment by explicating a theory of the "plantation economy." A variant of the dependency perspective, this theory declares that the most important medium of capital accumulation in the modern 
world system has been the plantation, which emerged in the Caribbean in the seventeenth century and which has continued to operate to the present day. Plantation economies are said to have exhibited the first form of capitalism in the New World (Beckford, 1972). They have been defined as being dependent on the export-oriented production of a single crop, located largely in the tropics, and possessing a strict division among races and between laborers and management (Jones, 1968:54; Beckford, 1972:13). The two earliest exponents of the plantation thesis, Best and Levitt, divide the historical development of the West Indian plantation econorny into three eras: 1) Pure Plantation Economy - from 1600 to the abolition of slavery in 1838; 2) Plantation Economy Modified - from 1838 to the onset of World War II; and 3) Plantation Economy Further Modified from 1938 to the present (cited in Payne and sutton, $1984: 2)$.

The first phase is especially important, for early dependency led "to burgeoning inequalities of both a social and spatial kind", which have persisted into the post-independence era (Cross, 1979:26). Plantations were almost exclusively owned by metropolitan interests, who failed to promote the economic development of the nost country. The relationship between the local economy and the faraway metropole was therefore a parasitic one. In the post-World War II era, this relationship has been maintained 
by transnational corporations. The mixture of foreign

ownership of capital, and export-oriented production and accumulation, has served to hinder self-sustaining economic development.

The plantation dependency theory suffers many of the same deficiencies of early dependency formulations. Much of the problem can be attributed to its structuralist framework. Consequently, the approach was static, over-economistic, and almost devoid of an analysis of class and the state. For example, Beckford (1989:163) recently noted:

My earlier analysis of plantation society...has several weaknesses...,specifically, its handling of the class question was overshadowed by the emphasis on race, whereas what is needed is a synthesis of how race and class makes plantation society a "special case" in the history of social formations.

An exception to the above was the work of the University of Guyana economist, clive Thomas. Building on the historical race/class analysis of walter Rodney (1981) and incorporating a neo-Marxist approach, Thomas situated the Caribbean, in the international division of labor, as purveyors of raw materials and procurers of manufactured goods. He noted that there is aldivergence between domestic resources and domestic demand - that is, production and consumption patterns do not reflect societal needs (Payne and Sutton, 1984:6). Whilst Thomas' analysis clearly specifies the importance of class and politics in production relations, he too falls into the "stagnationist" trap by 
harboring the idea that "peripheral capitalism" was doomed to failure in the Caribbean.

Unequal Exchange. Another variant, and a more sophisticated form of dependency theory, is associated with the "unequal exchange" concept of Emmanuel (1972), and later Amin (1976) and Mandel (1975). Emmanuel's concept of "unequal exchange" is derived from Ricardo's theory of comparative advantage; however, in this case trade serves to transfer value from the underdeveloped to the developed countries. Unequal exchange occurs due to wage differentials that cause a transfer of value from the low wage (peripheral nations) to the high wage (core nations). This process takes place even though both regions may employ the same capital-intensive forms of production and have the same productivity levels. Wage rates in the periphery are kept artificially low by institutionally determined income levels at the center. Unfortunately, the argument suffers from many of the deficiencies attributable to Frank's underdevelopment thesis. It lacks explanatory power, since it separates circulation from production. Also, it is static, since it precludes the possibility of independent development of productive forces in the Third World. Amin (1976), whilst subscribing to the unequal exchange theory, goes beyond it by attempting to incorporate class analysis. Amin's methodology recognizes capitalism as a world system that is based on exploitation and class 
relations, rather than a system of relations between nations. Amin (1976:360) internationalizes the class struggle by stating that:

The main contradiction between productive forces and production relations, is expressed, on the social level in the contradiction between the two opposing classes of the system: the bourgeoisie and the proletariat...the contradiction is not between the bourgeoisie and the proletariat of each country considered in the isolation, but between the world bourgeoisie and the world proletariat.

Amin perceives the domestic bourgeoisie as inconsequential, and the periphery to be largely undifferentiated. This is unfortunate, as the analysis ignores the wide variation of countries confined to peripheral status.

Dependent Development. Cardoso (1973), Cardoso and Faletto (1979), Bonilla and Girling (1973), and Evans (1977, $1979 b)$ demonstrate that it is possible to have mobility in the global capitalist economy through "dependent development". According to this formulation of the dependency theory, monopoly capitalism and development are not mutually exclusive terms; as a matter of fact, dependent capitalist development has arisen to be a new method of monopolistic expansion in the developing world.

Cardoso and Faletto (1979) dispute the early Frankian assumption that economic relations between nations are "static". They suggest that "forms of dependency can change" (Cardoso and Faletto, 1979:X). This point is illustrated by Dos Santos (1970), who distinguishes several 
versions of dependency: colonial dependency, financialindustrial dependency, and technological-industrial

dependency. The "new dependency" (Dos Santos, 1970), in effect since the end of World War II, is characterized by the investments of transnational corporations (TNCs). These TNCs are said to be responsible for limiting the development of Third World countries. The crux of the argument is that although some developing countries experienced rapid industrialization, they nevertheless exhibited signs of dependent development, owing to a lack of internal control over economic decisions. As Cardoso and Faletto (1979:XX) state:

From the economic point of view a system is dependent when the accumulation and expansion of capital cannot find its essential dynamic component inside the system.

It makes little difference whether or not firms are owned locally, since "they are linked to market investment and decision making structures located outside the dependent country" (Cardoso, 1973:146). According to Evans (1979a, 1979b) there is a "triple alliance" of foreign capital around which dependent development is maintained. In the Third World, so the argument goes, capitalists are not interested in the pursuit of national development, because they make their living from existing patterns and do not want competition from newer ones. Neo-Marxists criticize these theorists as simply describing the transition to capitalism that is occurring in the Third World. What is 
seen as dependent development is merely one form of this transition.

World-System Theory. An offshoot of dependency theory, the world-system theory has been widely identified with the work of Wallerstein $(1974,1976,1977,1979,1980$, 1984). Although generally in agreement with the dependency approach, it differs from its progenitor by providing a wider interpretation of the world economic system from which development and underdevelopment arise. It succeeds in this aspect by recognizing the world system as "dynamic," allowing countries the possibility of mobility through a three-tiered hierarchic world economy of core, semiperipheral, and peripheral countries (Nemeth and Smith, 1985; Timberlake, 1985). Furthermore, the world system shifts the unit of analysis from the dependent nation to the global economy.

If there is one thing which distinguishes a world-system perspective from any other, it is its insistence that the unit of analysis is a world-system defined in terms of economic processes and links, and not any units defined in terms of juridical, political, cultural, geographical, etc., criteria (Hopkins and Wallerstein, 1977:123, cited in Bach, 1980:295).

Despite the possibility of movement within the global economy, the world-system perspective concurs with dependency interpretations that the economic ties between the hierarchic tripartite world division of labor serves to "block" and "distort" Third World development. The core countries are dominant; they play a powerful and decisive 
role in economic exchange and international relations (Cohen, 1981; Chase-Dunn, 1984). They are comprised of wealthy societies with high degrees of economic diversity that control the world division of labor through foreign investment, aid, and other economic mechanisms. Peripheral countries are to be found at the opposite end of the spectrum from the core, "with not merely unequal exchange between them but also persistent trade imbalances, a multiplicity of state-structures... and the development over time of two principal world class-formations" (Wallerstein, 1976). They are dominated and have been forced into a subservient position as a result of their historical exploitation by the core. Control of economic processes has meant a reliance on, and an overspecialization in, the production of primary products (Roberts, 1978:15) . Finally, the semiperiphery can be defined as a middle stratum that lies between the core and the periphery. It is comprised of countries that are more diversified than those in the periphery, but which have not achieved the types of economic diversity associated with the core. It is said to act as a buffer between the core and the periphery, for the semiperiphery, while exploiting the periphery, is in turn exploited by the core. This arrangement serves to ensure poverty in the periphery and at the same time prevention of any alliance between the semiperiphery and the periphery. Wallerstein's world-system approach, although an 
advancement on early dependency formulations, suffers from many of the same weaknesses associated with the latter perspective. One problem with the dependency/world-system analysis is its emphasis on external relationships between social systems at the expense of internal dynamics (Hermassi, 1978; Portes, 1979; Nemeth and Smith, 1985; Smith, 1985). The focus on external relations "leads to an incapacity to differentiate the different moments of capital development, the specific configuration of types of capitals, the particular class relationships and conflicts engendered between capital and labour" (Petras and Trachte, 1979:126). Another criticism leveled against the dependency/world-system approach concerns its preoccupation with exchange relationships. By concentrating on the world market at the exclusion of social formations and state structures, proponents of the theory are accused of constructing an economically deterministic argument (Brenner, 1977; Skocpol, 1977; Forbes, 1984). By focusing on the circulation of commodities, critics contend, dependency/world-system analysts are "oblivious to the mode of production in underdeveloped countries" (Weaver and Jameson, 1981:100). The debate between the so-called "circulationists" (Frank，1966，1967，1978a，1978b，1980; Emmanuel, 1972; Amin, 1974, 1980; Wallerstein, 1974, 1979, 1980) and "productionists" (Meillassoux, 1972; Terray, 1972; Palloix, 1975; Rey, 1975; Shivji, 1976; Seddon, 1978; 
Taylor, 1979; Wolpe, 1980) has become rather acrimonious, so much so that Tilly (1984:68) describes the polemic as being played out on a "bloody field". Naturally, it is not possible to resolve the debate at this juncture. However, it does seem rather apparent that international and social relations do not operate in isolation, but dialectically. ${ }^{2}$

Dependency/World-System Theory and Dependent Urbanization: A Synthesis

Although the dependency/world-system perspective was overwhelmingly devoted to territorial referents larger than cities, the approach was instrumental in advancing the study of urbanization in the Third World. As Timberlake

(1985:3-10) states:

...processes such as urbanization can be more fully understood by beginning to examine the many ways in which they articulate with the broader currents of the world economy that penetrate spatial barriers, transcend limited time boundaries, and influence social relations at different levels...urbanization must be studied holistically part of the logic of a larger process of socioeconomic development that encompasses it, and that entails systematic unevenness across regions of the world. The dependence relation is an important

${ }^{2}$ In the last several years the trend in development theories appears to be towards synthesis. New modernization studies are now paying greater attention to historical analysis, concrete case studies, external forces, the positive role of tradition and religion in determining social change, and an acknowledgement that development is far from unilinear (Almond, 1987; Banuazizi, 1987; Davis, 1987; Wong, 1988). On the other hand, dependency/worldsystem theorists, without jettisoning the need to pursue analysis of the cyclical rhythms of the capitalist world economy, have begun to explore the connection between global dynamics and internal factors in shaping development trajectories (So, 1986; Chaichian, 1988). 
theoretical concept used to pry into the ways in which the processes embodied in the world-system produce various manifestations of the unevenness including divergent patterns.

Castells (1977) was the first to make the connection between dependency and urbanization in the form of "dependent urbanization." Within this construct, the city is seen as the outgrowth of capitalist penetration. It is established to extract a surplus, to expand the market for goods manufactured under advanced monopoly capitalism, to serve the needs of elites and to spatially concentrate production (Harvey, 1973, 1978, 1982; Friedmann and Wulff, 1976; Lojkine, 1976; Walton, 1976, 1977; Roberts, 1978; Mingione, 1981; Safa, 1982; Chase-Dunn, 1984). Castells (1977:47-8) proposes that:

...dependent urbanization causes a superconcentration in the urban areas (primate cities), a considerable estrangement between these urban areas and the rest of the country and a break in, or the non-existence of, an urban network of functional interdependencies in space.

In addition to the macrocephalic nature of urban growth, the disparities between urban and rural areas, and the spatial fragmentation of the urban system, it is further hypothesized by dependency/world-system theorists that urbanization under peripheral capitalism should be characterized by a number of supplementary features. These include, unemployment and underemployment, tertiarization and the absorption of a large percentage of the urban labor force by the so-called "informal sector," the growth of 
shanty towns and unregulated settlements, and the increasing segregation of class, status, ethnic, and racial groups (Portes and Walton, 1976; Roberts, 1978; Lubeck and Walton, 1979; Gilbert and Gugler, 1982; Safa, 1982; Walton, 1982; Armstrong and McGee, 1985; Timberlake, 1985; Smith and Nemeth, 1986). Given the macropatterns associated with dependent urbanization, dependency/world-system analysts for the most part have focused on the issue of urban primacy (Hardoy, 1975; Quijano, 1975; Vapnarsky, 1975; Gilbert, 1980; D. Smith, 1985; Walters, 1985). Despite certain advantages (such as a location that has easy access to global markets, or the presence of a large labor pool), a great deal of evidence has been accumulated with respect to the potential "parasitic" effects of primate cities (Frank, 1969 ; Cornelius, 1975; Portes, 1976; Walton, 1976). These authors contend that primacy "is both a sign and a result of the economic dependency that is causing underdevelopment" (C. Smith, 1985:97). Primate cities draw a disproportionate share of rural-urban migrants; they monopolize professional and skilled personnel, leaving other areas without badly needed services; they siphon rural resources whilst returning little if anything to these areas; and they command more than their fair share of the national income, leaving behind the rest of the country. Lipton (1977:19) notes that this disparity occurs because there is an implicit "urban bias" between the rural and urban sectors. 
Urban bias rests on convergent interest. Industrialists, urban workers, even big farmers, all benefit if agriculture gets squeezed - provided its few heavily subsidised resources are steered to the big farmer to produce cheap food and raw materials for the cities. Nobody conspires, it is not necessary, all the powerful are satisfied whilst the small scale peasant farmer remains poor and powerless. Meanwhile, the planners often in the blinkers of industrial determinism, congratulates all concerned on resolutely extracting an agricultural surplus to finance city development and industrialization.

on the other hand, at the international level, the association between the primate hinterland city and the industrial metropole is biased in favor of the latter. Primate cities in the developing world have applied command over resources from their rural periphery; and via migration, trade and monetary flows, and external movement to the metropole, they have been incorporated into the global pattern of relationships. Internally, the widespread inequitable association between city and country in developing nations has resulted in the retardation of the rural areas; in other words, urban development has occurred at the expense of rural areas. This has resulted in a swift demographic transformation from the country to the primate city in particular.

The result of this rural-urban migration process often does little more than effect a transfer of rural poverty to urban areas. When there are only a few unskilled, poorly remunerative jobs and an oversupply of workers vying for them, the effect is to lower incomes even further. Large 
numbers of unskilled laborers and service workers are perpetually finding their low wages bid even lower by the hordes of new migrants who are migrating from depressed rural areas and congregating in the cities. The result is severe unemployment and underemployment. In most developing countries, the modern sector of the economy is only a tiny fraction of the whole. Thus, in spite of some gains in industrial productivity and some increases in per-capita incomes, the rate of unemployment and underemployment remains high and continues to advance more rapidly than that of urbanization.

Geographers describe the majority of urban employment as residing within the tertiary or service sector. However, the dominance of service employment within these cities does not arise from the production of some massive surplus of wealth fashioned by high-productivity industries, as was the case in Europe and North America. Rather, it is predicated on the maintenance of low-productivity jobs, which are unable to generate the required surplus for most families. In addition, the types of jobs classified as belonging to the service sector cover a decidedly wide terrain, from a doctor to a street vendor. It is almost a residual category, a "chaotic abstraction" that can merely allude to the problem at hand (Sayer, 1984). It is believed that the term "informal sector" or "petty-commodity production" more accurately portrays what is happening to labor in the 
developing world.

The informal sector is composed of unregulated, small-scale, self-employed "entrepreneurs" utilizing laborintensive methods with minimal remuneration and limited job security. Whilst there are conflicting views on the role of the informal sector, dependency/world-system analysts assert that this form of petty-commodity production stymies national development and further underdevelops the Third World (Portes and Walton, 1981; Portes, 1985; Safa, 1986). This sector is perceived as subsidizing the formal sector in the periphery by providing cheap goods and services, lowering wages throughout the urban economy, and facilitating social reproduction. Furthermore, the international economy benefits from the growth of this sector. Transnational corporations (TNCs) are able to reduce their costs so that "the apparently isolated labor of shanty town workers can be registered as gain in the financial houses of New York and London" (Portes, 1985:62). The problem of informal sector labor in a peripheral capitalist city is intimately linked with another inescapable urban problem, the proliferation of shanty towns and squatter settlements. In addition to swamping the labor market, depressing wages, and augmenting the ranks of the unemployed, rapid urbanization has had a detrimental effect on the capacity of Third World governments to provide such basic services as housing, public health, and education for 
their citizens. Their populations reflect severe intraurban inequality. They are crammed into high-density settlements that are unplanned and bereft of essential services such as potable water and sanitation. Insofar as these settlements are peripheral or segregated ecologically, it is more a reflection of dire necessity than conscious choice. Whether or not one subscribes to the "dependent urbanization" thesis, one is compelled to acknowledge that since the sixteenth century, mercantilism and later industrial capitalism have largely influenced urbanization patterns the world over. Thus, Gilbert and Gugler (1984:13) suggest:

\footnotetext{
... it is possible to argue that without the intrusion of industrial capitalism and imperialism some Third World societies would still lack major cities. In major parts of America and Africa urban development was superimposed by capitalism on essentially rural societies.
}

\section{METHODOLOGY}

Having reviewed the theoretical literature and its relevance in providing an explanation for social change and development, this section will specify the researcher's method of analysis. Given the fact that all social science endeavors are ideological in the sense that they represent a particular vision of the world, I have chosen to couch my analysis within a framework that might be considered radical, but which I believe most appropriately explains patterns and processes of urbanization in Guyana. That 
methodology is the international political economy of the dependency/world- system perspective. The schematic discussion of "dependent urbanization" in the previous section is intended as a series of implicit hypotheses, which are explored in the course of this thesis. That is, dependency is expected to affect urban primacy, unemployment and underemployment, informal sector employment, intra-urban inequality, the growth of shanty towns and squatter settlements, retardation in rural areas, and accelerated rural-urban migration. Given these features, a key issue is the extent to which urban areas in Guyana conform to this "dependent urbanization" schema at various stages of its history. Can Guyana be characterized as a classic case of dependent peripheral capitalism, with all that implies? I am aware that it would be foolhardy to try to force Guyana into a teleological and deterministic framework. Hypothesis testing is not a "sine qua non" for history. Instead, the dependency/world-system perspective is utilized as the study's point of departure.

The theory of "dependent urbanization" serves to bring some order to the complexities of urbanization under peripheral capitalism, but it cannot and should not be reified to become reality. Cognizant of the differing versions and the deficiencies of this perspective, I should state the outlines of my approach. The thrust of the study is historical-structural. Thus, it analyzes the urban 
system in Guyana as an open one, which interacts with a wider national and international system. Furthermore, it perceives urbanization as a holistic societal process, which must be explained by societal and intersectoral models within a historical perspective. Not only will a historical method enhance comprehension of urbanization and its institutional framework in Guyana, but it will also assist in grasping the relevance and the justification of the goals and actions of planners and decision makers. This point is illustrated by Beckford, (1972:v) who writes:

In every society the institutional environment is a legacy of historical forces and it is through institutions that human activity is organized.

More recently, Abbott and Adler (1989:467) have demonstrated the importance of "historical analysis" to planning praxis. They suggest:

Approaching planning situations with historical questions provides a practical way for defining and exploring the institutional and theoretical settings of those situations.

There is no doubt that a historical approach provides us with a clearer understanding of the present, for in Guyana and elsewhere, the mode of life today is deeply rooted in the past. The socioeconomic structure, and the urban system it has produced, can be thoroughly grasped only by situating them in historical perspective. As Castells (1977:7) observes:

...a study of the history of the process of urbanization would seem to be the best approach to the urban question, for it brings us to the 
heart of the problematic of the development of societies...

Dependency/world-system theory speculates that urbanization processes take a considerable amount of time to unfold, and the only way to determine the factors that are important is through a historical approach. Therefore, the origins of Guyanese urbanization must be understood by a thoroughly grounded understanding of history over the last 400 years. That is, urban growth and patterns in the country can be better understood by the timing and incorporation of Guyana into the capitalist world system. In addition, this historical research will consider the ways in which distinct factors such as state, race, class, gender, and the environment have combined to shape the process of urbanization. The goal here is to attempt to link the unnecessarily polarized debate between the "productionist" and "circulationist" viewpoints, as well as to provide a more synthetic theory. The thesis, as a result, considers urbanization as a dependent phenomenon that stems from various "internal" and "external" components influencing one another and the society within which the process takes place. clearly, external conditions alone cannot explain everything. Although, in step with our dependency/world-system framework, I do acknowledge that the global capitalist economy constrains development and distorts urbanization in the developing world. More emphasis, therefore, should be bestowed on those internal 
elements that can influence urbanization. I concur with those who profess a realist epistemology that internal conditions are important (Cooke, 1983; Sayer, 1984; Corbridge, 1986). Third World countries are not simply passive victims waiting for history to unfold. To quote Sayer (1984:22), "history not only happens to people but is made by them, consciously or unconsciously." or, as Zimbalist $(1980: 28)$ notes:

Dependency theory treated underdeveloped countries largely as putty, uniformly moulded and deformed at will by foreign capital.

Researchers must journey beyond their narrow perspectives and throw off the yoke of barren typologies. The occurrence of aberrant individual cases is perhaps inevitable, given the uniqueness of historical experiences. Careful evaluation must be made of the reasons for the anomalies and any peculiar circumstances and specific conditions which may be discerned. It is erroneous to explicate the urbanization process as being completely asymmetrical, for there is a dynamic interaction between external and internal forces. What we are endeavoring to accomplish is to formulate an approach that is flexible enough to study the external and internal dynamics, in order to comprehend the political, economic, geographic, and cultural relationships which have conditioned urbanization. The emphasis is on linking changes in Guyana's pattern of urbanization with the historical context in which the 
country was incorporated into the global economy. What has been the role of external factors and indigenous forces in shaping the urban system? Why did settlements spring up in particular locales? What functions did they perform? Why did they expand in particular ways? I will begin by suggesting that Guyanese urbanization cannot be understood without consideration of the external economic orientation that Dutch, French, and British colonialism has imposed since 1580. Guyana's urbanization patierns have been contingent on the nation's incorporation into the world economy. This will help to explain some of the present settlement configuration.

A key issue throughout this study is the role of the state over time. I hope to show that the state has played an essential part in Guyanese urbanization. I will pay particular attention to specific urban policies that have been pursued through the course of the nation's history and how these policies have maintained or altered the urbanization process. Specifically, I will attempt to tie in the provision and distribution of infrastructure (roads, railroads, shipping, electrification, running water, hospitals, and institutions of higher education) in Georgetown as a major contributor to its continuing primacy. Does Georgetown receive governmental resources that are commensurate with its output and in proportion to its size, or as a percentage of its share of the national population? 
Most importantly, in the course of the thesis, I will be examining the generation and allocation of economic surplus as a crucial element in accounting for Georgetown's supremacy. By examining the state's revenue and expenditures I hope to determine the extent to which economic surplus is being concentrated in the urban areas. I will look in some detail at how the economy operates, and at the proportionate importance of the various sectors. Given the wide array of infrastructural facilities, I will consider in particular, the development of the transportation/communication systems and how they have sustained the spatial structure. The transportation network in Guyana can be best described as "dendritic". That is, like a river, the transportation system consists of many feeder roads connected to the only major road leading to the capital, with no direct links between the feeders. This is not a random occurrence, as Suret-Canale (1971:193), writing of French West Africa, observes:

Each economic region corresponds to a "one-line economy," an axis based externally on a port where import and export were conducted and comprising a series of adjacent branches which sub-divide in turn until they peter out in the bush...each region resembled a kind of lung with its system of veins and arteries running parallel, receiving its oxygen at the level of agricultural production. But the heart was placed outside, far beyond the seas, the impulses that regulated the nature and intensity of the flow were external ones.

I will pursue an analysis of the class structure, especially those in political power, in order to determine 
why certain features of the economy have been accentuated and why surplus has been concentrated in particular areas. By utilizing class analysis, one endeavors to define the economic interests of various power groups within the socioeconomic structure. This allows one an insight into the society in order to evaluate what forces are at work in determining events. Which classes benefit from developmental policies and which classes are exploited? Are policy outputs rendered according to public need, public interest, or something other than consumer demand? Does implementation of policies serve the needs of the elite? with the advent of inciependence, the initial cause of Georgetown's primacy (i.e., its external orientation) was supposedly ended as old mechanisms were restrained or removed. Development of Guyara is now the responsibility of the Guyanese people and its government. Why then has the city continued to dominate the urban hierarchy in the modern period? Explanations that attribute the present situation to social inertia or initial advantage are inadequate. However as Soja (1976:27) states:

Institutions and policies may change, but it is difficult to begin shifting around railways, processing factories, and the whole urban settlements to suit changed objectives and altered ideologies.

Rather, we must investigate the manner in which the class of elites, located in Georgetown, have formulated policies to enhance their power base. It is argued that 
despite all the posturings and socialist rhetoric of the post-independence regime, there have been no real changes in the structure of any of the nationalized industries (sugar and bauxite being the major enterprises). Instead, what we expect to find is a replacement of the colonial elite by an indigenous elite. Throughout Guyana's history, agriculture has been the main productive base of the economy, and the rise and fall of various urban settlements can be more fully understood in the context of changing conditions in the rural areas. The argument here is that structural causes of urbanization reside in both rural and urban structures. In the agricultural sector, the plantation has been the dominant system of production, with sugar as king. The form and tempo of urbanization have been determined to a large degree by the fortunes of sugar plantations. Many of the early settlements evolved mainly around plantations. Georgetown, New Amsterdam, and several other urban centers were originally plantations which were transformed into villages. As a result, it is essential to the understanding of contemporary urbanization to trace the evolution and development of the plantation system, and its relationship to the rest of the rural economy and to the wider society. It would, however, be erroneous to magnify the contribution of the plantation. It was, after all, merely a part of the institutional framework of the Guyanese economy, one form of production. 
The rice and bauxite mining industries have also played important roles in Guyana's demographic and economic history. Accordingly, I will integrate the contribution of each into my analysis. I am also aware that urbanization is a spatio-demographic process (Slater, 1978). The spatial concentrations of agricultural and mining pursuits have generated settlement and urban patterns and processes. Unfortunately, dependency/world-system has virtually ignored the relative importance of these urbanization components and has placed too much significance on socio-political variables. From a spatio-demographic orientation, we need to incorporate demographic growth into our study of "dependent urbanization" in Guyana. For example, what has been the impact of state policies on population growth? Furthermore, we must begin to appreciate that the geography of resources does matter (Corbridge, 1986). The physical environment must be assessed in a comprehensive urbanization study such as the one at hand. How and in what ways has the country's physical geography influenced settlement patterns? Why does 90 percent of the nation's population reside on 4 percent of the available land mass? An unsophisticated environmental-determinist view of urban growth is, of course, untenable. There has been uneven development. Some of the reasons can be attributed to local ecology, but the differential allocation of capitalist investment and the capacity of the society to utilize the 
environment must be readily acknowledged. Thus, environmental-determinism and scale cannot be considered as the sole explanatory factors for the concentration of population and economic activities leading to capital-city primacy.

What I am endeavoring to do principally is to offer a coherent account of the urbanization process in Guyana, an account that serves to explain rather than describe this intricate process. I am aware that a dogmatic adherence to the dependency/world-system perspective is inadvisable. As a result, I have sought to incorporate human agencies, possible politics, and demographic and environmental variables into the analysis. I would hasten to add that this approach is not a retreat from theory. Rather, it is an appreciation of the fact that urbanization in a peripheral capitalist state is a historically variable event. My approach could be criticized as "crude eclecticism." Nevertheless, I firmly believe that the pursuit of a broad analytical base in order to allow a greater synthesis of several approaches has merit. obviously, complete synthesis is well nigh improbable, if not downright impossible; however, it is only by such an approach that one may adequately study urbanization and be able to prescribe policies that are sufficiently comprehensive in nature. Dependency/world-system theory has been roundly criticized as a guide to effective action. 
However, this study ought to alert indigenous planners that before any planned intervention can succeed, they must take into account external economic dependence, externally propelled value systems, internal politico-social variables, and the usual demographic and environmental characteristics that drive the process of urbanization.

\section{DEFINITIONS}

This thesis is concerned with "urbanization in a peripheral capitalist state"; accordingly, one needs to clarify the concepts that will be utilized throughout the study.

\section{Urbanization}

The concept of "urbanization" has been described as a balloon into which each social scientist blows his own meaning (McGee, 1971:10). For this study's purposes I have adopted the definition proposed by Roberts in his path-breaking classic, cities of Peasants: The Political

Economy of Urbanization in the Third World. Roberts (1978:9) declares:

... we must broaden our focus to take in the whole process of urbanization and not simply that of contemporary urban growth...cities are the products of broader socio-economic changes, they cannot be considered in isolation from them. Urbanization in its most formal sense merely constitutes the increase of the urban population as compared with the rural one, but it includes and results from far-reaching economic transformations on the national and international plane. 
Roberts' definition has the advantage of combining the "demographic" expression of urbanization (i.e., natural increase, migration, and urban transformation) with the "socioeconomic" dimension. It connotes urbanization as a social process rather than simply a rise in the proportion of the total population living in places deemed urban.

\section{Peripheral Capitalist state}

This term denotes a society which, by its insertion into the world-system, has a couple of peculiar features. First, a capitalist mode of production is juxtaposed with non-capitalist forms, with the former being dominant. And second, the core has hegemonic influence and power to perpetuate this type of development.

\section{Dependency}

Dependency is viewed as an asymmetric form of integration into the world economy. It is "a situation in which the economy of certain countries is conditioned by the development and expansion of another economy to which the former is subjected" (Dos Santos, 1970:231).

\section{EVALUATION OF SOURCES}

The research aspires primarily to provide a qualitative analysis of the chosen theme. Much of the description is selective, drawing from a range of primary, secondary and tertiary data. Guyana's legacy of 
underdevelopment is also reflected in the limitations in the material base for historical reconstruction. There are no reliable statistical series although the first census was taken in 1841 and the registration of vital statistics can be traced back to 1869 . Censuses were taken regularly in ten year intervals until 1901 when a shortfall in revenue caused a postponement until 1911. The second World War also prevented collection of the 1941 census, whilst in 1980 the government chose not to publish the results. The lack of quantitative data required some creativity on our part. However, the situation is not entirely hopeless. A reconnaissance trip was made to Guyana in September, 1989 to evaluate the adequacy of available data and to forge links with the state Planning Secretariat, the central Housing and Planning Authority, and other government departments. The trip proved to be a fruitful one; generous amounts of contemporary data was furnished including annual reports and development plans. Although researchers in the past have found administrative records difficult to access, a large amount of primary data was made available. The University of Guyana Library and Geography Department also proved somewhat useful as sources of secondary data. A number of unpublished papers, journals, and books not found outside Guyana were consulted. However, because of a poorly developed historiography, much of the information that is salient to us occurs in a disparate fashion and had to be 
pieced together. More dated materials were located at the Guyana National Axchives (GNA). The GNA has conserved a number of bound volumes and miscellaneous papers. The series of bound volumes allows for scholarly reference. These include, Blue Books, Official Gazettes and copies of many decennial censuses. Finally, I drew from a wide array of sources, including the works of anthropologists, demographers, historians, sociologists, economists, political scientists, and urban planners. The resultant study is thus an interdisciplinary approach.

\section{ORGANIZATION OF THE STUDY}

This study is divided into six chapters. Chapter I is the introduction. It sets the stage by describing the scope of the study, its rationale, and its organization. An in-depth literature review is pursued, to make explicit and comprehensible the theoretical framework of the thesis.

The first section of Chapter II presents the contextual framework by laying the foundation for our investigation. It presents background information on the geographical characteristics of the country. The country's economic and cultural history has profoundly influenced population growth characteristics and distribution. For orderly and chronological treatment, the discussion of these factors is structured into four historical phases. These are, respectively: 
1. Early colonialism and slave plantation society (1580 to 1838$)$;

2. Post-emancipation and indentureship (1838 to 1917);

3. Twentieth-century colonial rule (1917 to 1966);

4. Post-independence (1966 to the present).

A cursory glance at the above periods reveals that they are of unequal duration. However, such a structure allows one to analyze the changes which occur when one socioeconomic arrangement is altered or supplanted by another. The periodization of history is not meant to suggest a past devoid of process. Many of the key historical processes identified by this study have their roots in earlier phases; likewise their legacies overlap strict chronological boundaries. In this thesis, the four phases will be presented in four chapters representing welldefined eras in the political economy of urbanization in Guyana. Any such discussion of the evolution of society is axiomatically a discourse of historical events. Therefore, chapters II through $\mathrm{V}$ are largely historical, with the analytical accentuation on the demographic, spatial-ecological, and politico-economic factors of urbanization. I will delineate the developments leading to the primacy (demographic, political, social, and economic dominance) of the capital, Georgetown. Special attention is placed on the national political arena, with emphasis on the policies of the elite class as they relate to 
infrastructural development in particular. This will provide us with some understanding of the major factors which fashioned the current pattern of settlement and which still continue to have important effects on urban development. Each of the four chapters (i.e.,II through V) roughly follows an order of delineating:

1. Global Linkages. According to world-system theory, a social process such as urbanization must be understood in its international context. The whole idea behind dependent urbanization is that it is closely associated with capitalist penetration and expansion. Therefore, in this section, I will be looking at external economic depenaence. What are the economic processes that link Guyana (an economic satellite) to the core? The chain of metropolissatellite links are especially important because it does not only help to explain underdevelopment but it also throws light on the country's urban history. In the early colonial period the national transfer of economic surplus occurred directly between the plantations and metropolitan centers. It was only later that the extraction of economic surplus was accomplished through a chain of exploitative relations which flowed from the countryside (plantations), to Georgctown, and finally to western metropolises. The linkages between core and periphery are presented by demonstrating import and export concentration (a reflection of dependence and openness of the economy), trade patterns, 
port traffic (arrivals and destinations), and international relations.

2. Industrial structure. One of the most important influences on urbanization is the nature and location of employment. Consequently, when the settlement pattern is considered, the type of industrial structure is extremely important. During each particular era, I will look at the proportionate importance of the various sectors (agriculture, manufacturing, mining, and services). 3. Demography. A study of urbanization cannot proceed without an analysis of demographic trends in the area under investigation. Accordingly, throughout the various periods, I will present basic demographic data such as natural increase (i.e., the difference between the number of births and deaths), migration, racial composition of the population, gender ratio, etc. In addition, I will include the number, size, distribution, hierarchy, growth, and structure of the urban areas - primarily Georgetown and New Amsterdam.

4. Infrastructure and Urban Development. The provision of infrastructure is an important causal agent in shaping land use and settlement patterns. A basic assumption of this thesis is that people move where resources and opportunities are concentrated. Accordingly, in this section, I will concentrate on infrastructural allocations (roads, railroads, shipping, electrification, water supply, sea 
defenses, educational institutions, and hospitals) and development expenditures as they relate to urban and rural areas.

Within the urban areas, I will address the problems posed by urban growth and urbanization, and the extent to which urban areas in Guyana conform to a dependent urbanization scheme - urban primacy, unemployment and underemployment, petty-commodity production, intra-urban inequality, squatter settlements, and accelerated ruralurban migration.

It is through the political and social structure that infrastructural developments and other policies affecting Guyanese urbanization are formulated and implemented. As a result, I will discuss the role of the state, race, class, gender, and elite interests. Have the dominant groups in the society exerted an "urban bias" over the political system? How are government resources allocated with respect to infrastructure? How has the tool of planning been used in influencing land use? What are the institutional roots behind settlement patterns? I will also discuss how the dominant class has utilized the rule of law, particularly Crown Lands legislation and labor laws, to promote their interests and those of the dominant classes in the core capitalist countries. Chapter VI, the conclusion, summarizes the findings of the dissertation. 
CHAPTER II

EARLY COLONIALISM AND SLAVE PLANTATION SOCIETY 1580-1838 GEOGRAPHICAL CONTEXT

Guyana is situated on the northeastern coast of South America between $1^{\circ}$ and $9^{\circ}$ north latitude and $57^{\circ}$ and $62^{\circ}$ west longitude (Figure 1). It is bordered by the Atlantic Ocean on the north, Surinam on the west, Brazil on the south and southwest, and Venezuela on the west. With an area of 83,000 square miles $(215,000$ square kilometers), it is slightly smaller than Great Britain, although it is by far the largest country in the Commonwealth Caribbean.

Guyana can be divided into three broad geographical regions - the coastal plain, the highland and forest region, and the savannahs. The coastal plain, containing the bulk of the country's population, stretches 270 miles along the Atlantic coast and varies in width from 10 to 40 miles. It is a flat, low-lying area, most of which lies below sea level at high tide, and has to be protected from the ocean by a complex and expensive system of sea defenses and drainage canals. Composed of rich alluvial soils, this 


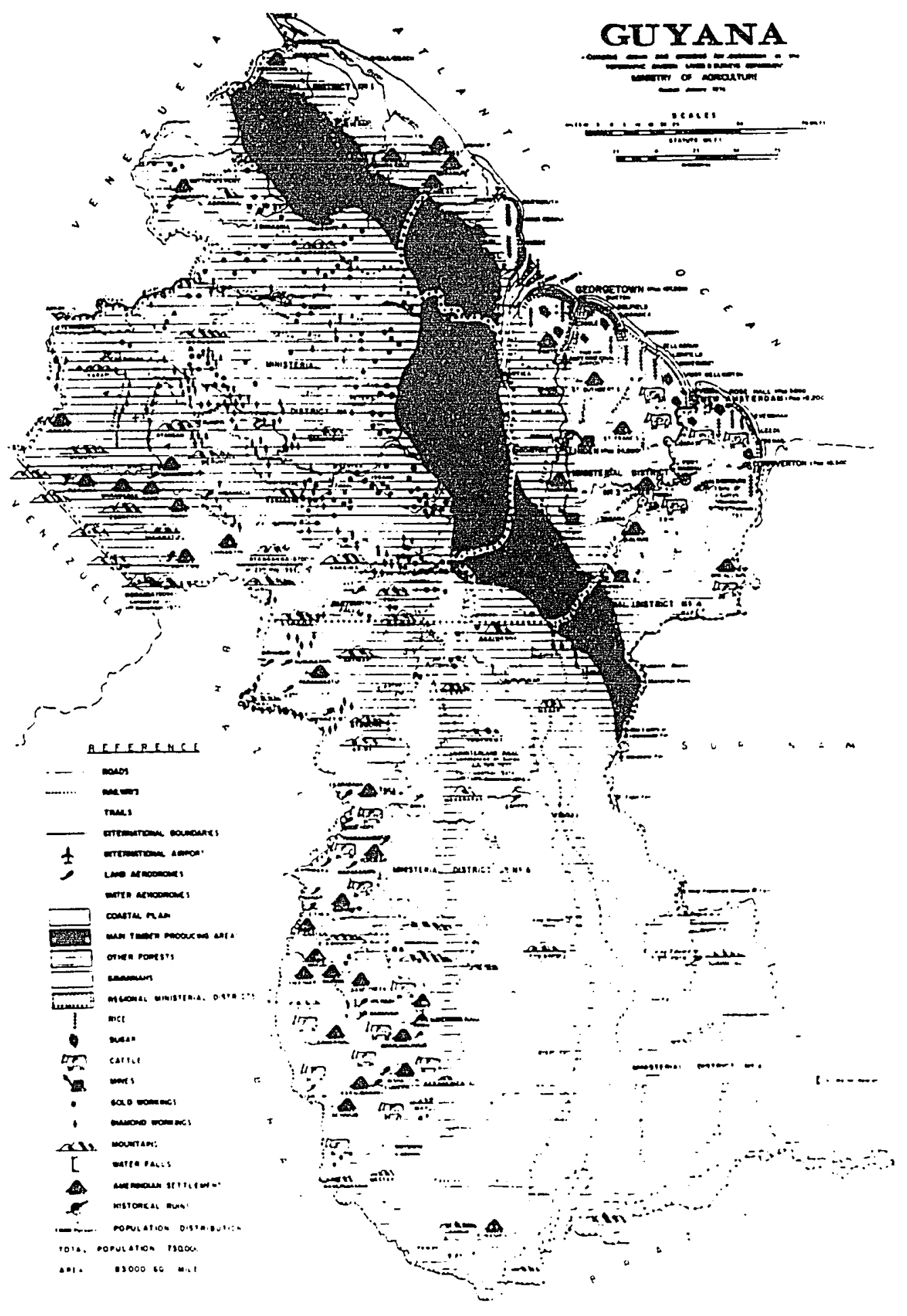

Fiqure 1. Guyana. 
narrow coastal ribbon is the most fertile region of the country. It is Guyana's agricultural center, and it is where the sugar and rice industries are to be found.

Extending southward from the coastal plain, there is a broad belt of undulating land that is characterized by dense equatorial forests. There are several mountain ranges including the Pakarimas, the Imatakas, the Kanukus, and the Sierra Akarais. The most significant range is the Pakarimas, which extend along the Venezuelan and Brazilian borders. Here one finds Guyana's highest peak in Mount Roraima - 9,094 feet above sea level. Numerous rivers cross the region, but navigation is generally hampered by cataracts, rapids, and waterfalls which frequent the courses. This region also boasts the mighty Kaieteur Falls, which at 741 feet is one of the largest single-drop falls in the world.

While the highland and forest region covers approximately four-fifths of the country, it is largely undeveloped and unpopulated. The soils are sandy and infertile for the most part. However, the region is thought to have extensive reserves of minerals including bauxite, gold, diamonds, manganese, and columbite. In addition, the forests contain valuable strands of hardwood including greenheart, mora, crabwood, wallaba, and other timbers. 
There are two savannahs - the Rupununi and the Intermediate. The largest, the Rupununi, is located in the southwestern part of the country and comprises an area of approximately 6,000 square miles. This is the country's major cattle-rearing area, but because the quality of the soil and grasses is poor, the number of cattle per acre is rather low. The Intermediate savannahs, located 60 miles up the Berbice River, covers an area of some 2,000 square miles. Although it is more accessible than the Rupununi, the grass here is of poorer quality, and as a result fewer cattle are reared.

The country is traversed by four major rivers (Essequibo, Demerara, Berbice, and Corentyne) flowing north from the southern interior to the Atlantic. Essequibo, Demerara, and Berbice also represent the names given to the three counties into which Guyana is divided. Each of the three was also a European colony. The Corentyne forms the border with Surinam.

Population estimates in Guyana are a matter of some conjecture. However, in 1989 the country's statistical Bureau estimated the population at 755,200 . Of the population, Indians and Africans comprise the majority, although there are smaller groups of Amerindians, Chinese, and Portuguese and other Europeans. The Amerindians are the only group which are indigenous to Guyana. All the other groups were introduced into the country as a result of 
Guyana's incorporation into the modern world system. Most were brought in as slaves, indentured and free laborers by the Europeans, to provide the necessary labor for cotton, coffee, and sugar plantations. Thus, Guyana's population and settlement history is a product of the development of the Atlantic world and a reflection of the expansion of capitalism, and European colonialism in particular, on a world scale.

The population is found largely on the easily accessible coastal plain. All principal urban centers are concentrated along this narrow strip of land. Georgetown, the capital and only city in the country, is the financial, commercial, and administrative center, and the chief port (Figure 2). It is located on the East Bank of the Demerara River estuary, and with its suburbs it has a population of $150,368(1986)$.

New Amsterdam, which in 1980 had an estimated population of 19,287 , is situated on the East Bank near the mouth of the Berbice River (Figure 3). The town, which has a relatively small port, is mainly an administrative center for Berbice, although it does provide some central place functions for people living on the eastern part of the coastal plain between the Berbice and Corentyne Rivers. Linden, with a 1986 population of 29,036 , is the country's second-largest urban center. It is located on the Demerara River, some 65 miles upriver from Georgetown. 


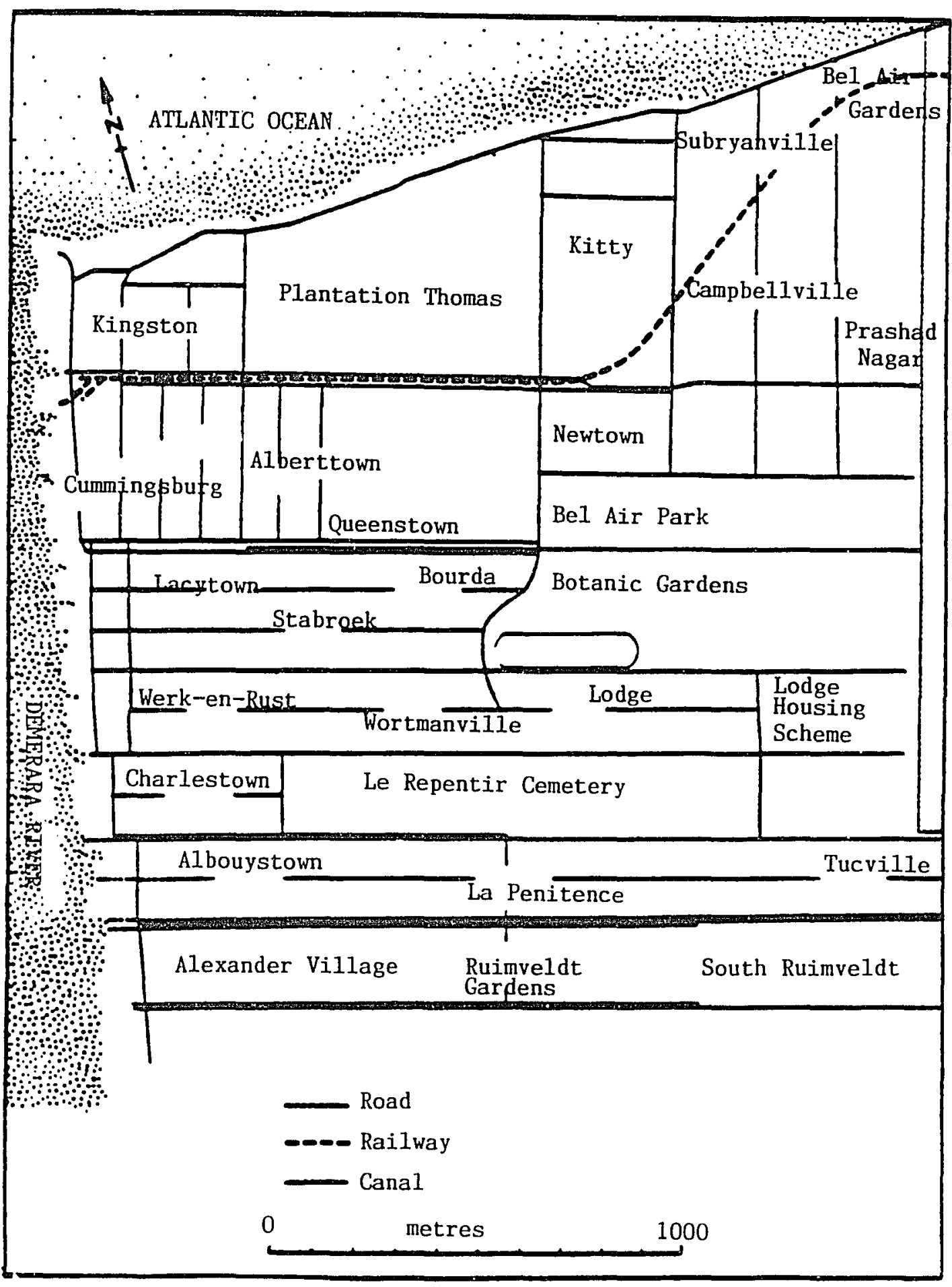

Figure 2. Georgetown. 


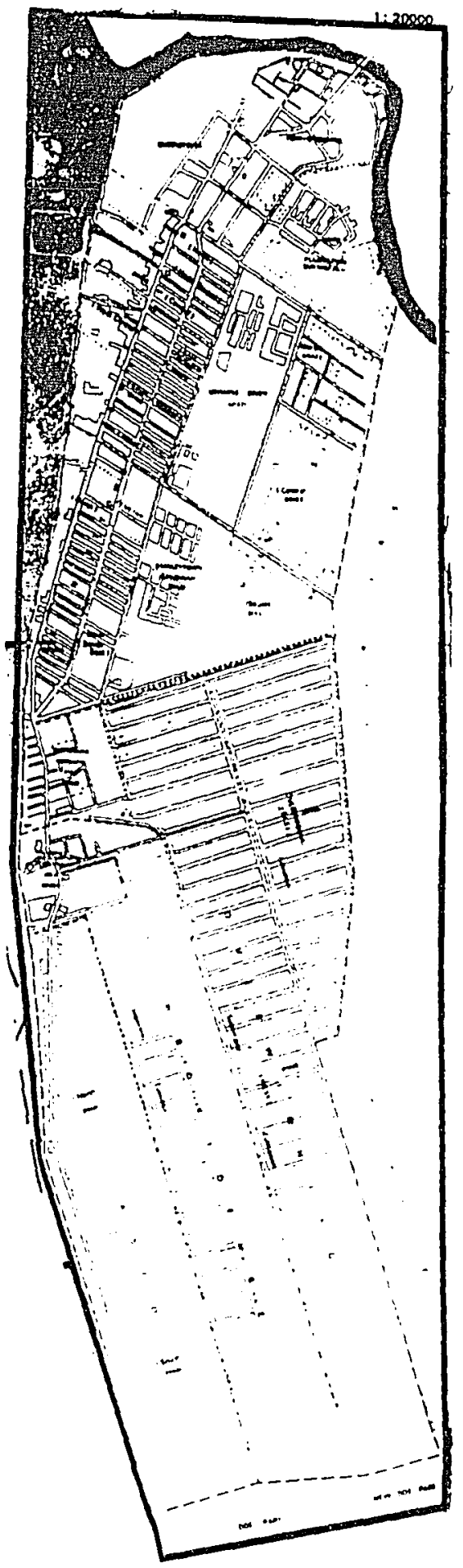

Figure 3. New Amsterdam. 
Formerly known as Mackenzie, the town is the country's most important bauxite mining center.

Corriverton lies on the West Bank at the mouth of the Corentyne River. Stretching for some seven miles along the Corentyne highway, the town is rather elongated. It was formed through the amalgamation of a number of villages and was declared a town in 1970. The town's port of springlands is of some importance, and its proximity to surinam has assisted its development as an important commercial center. In 1980, it had an estimated population of 15,000 .

The town of Rose Hall was also established in 1970 . Situated some 18 miles east of New Amsterdam, along the corentyne highway, it is a commercial center and in 1980 had a population of 5,311 .

\section{GLOBAL LINKAGES}

This section profiles Guyana's incorporation into the modern world system. Through discussion of trade links, and flows of capital and primary products (sugar, cotton, coffee, and tobacco) from the periphery to the metropolitan economies, it seeks to demonstrate the importance of export specialization in the formation of the space economy. In addition, it emphasizes Guyana's tenuous position in the midst of international geopolitical rivalries. Guyana was one of Europe's earliest colonial territories and consequently can be regarded amongst the 
modern world system's oldest peripheries. The country was thoroughly subsumed into a colonial stratagem that has resulted in a dissonant history, one in which the indigenous population, Amerindians, predominantly Arawak- and Caribspeaking groups, were largely marginalized through a policy of benign neglect, and replaced by immigrant peoples, emergent creole cultures, and new systems and forms of production and exchange.

Guyanese settlement history did not commence with European expansionism, despite the fact that Europeans regarded Guyana as a virtual tabula rasa at the time of contact and colonization. The Amerindians had no urban settlement of any significant size. At the time of contact, indigenous populations practiced shifting cultivation, fishing, hunting, and gathering. They occupied villages usually situated in relation to water sources; they engaged in long-distance trade.

Europeans first became aware of Guyana when they began charting the northeast coastline of South America during the waning years of the fifteenth century.' It is unclear whether Columbus sighted the Guyana coast during his 1498 voyage of discovery to the New World, but there is little doubt that Spanish and Portuguese explorers were cognizant of its existence by the early sixteenth century. Impelled

'Great Britain. Central office of Information. 1966. Guyana. London: H.M.S.O., p. 5. 
by a mercantilist philosophy that emphasized the control of trade and territory, the explorers soon attempted European settlement on the Guyana mainland. European settlement of the country quickly transformed the existing production patterns of the Amerindians and replaced them with new forms of production relations. ${ }^{2}$ Amerindians were forced to occupy more marginal regions of the interior.

Early European settlement was largely an outgrowth of the trade the Dutch had developed with the Amerindians. Annatto dye, letterwood, cotton, and tobacco were obtained by the Dutch in exchange for axes, knives, fish hooks, glass, pottery, and other merchandisable articles. ${ }^{3}$ As the Amerindians were largely nomadic, the Dutch were often confronted with severe delays in acquiring commodities from them. With a view towards efficiency, they established depots to allow greater contact with their trading partners. ${ }^{4}$ These trading posts were manned by a few Dutchmen, and they became the nucleus of European settlement in the colony.

${ }^{2}$ Thompson, A. 1987. Colonialism and Underdevelopment in Guyana. Bridgetown: Carib Research, p. xvi. According to Thompson, the social system of the Amerindians was "basically egalitarian" during the pre-European era.

${ }^{3}$ Goslinga, C. 1985. The Dutch in the Caribbean and in the Guianas, 1680-1791. Dover, New Hampshire: Van Gorcum, p. 432. Smith, R.T. 1962. British Guiana. London: Oxford University Press, p. 15.

${ }^{4}$ Rodway, J. 1891-94. History of British Guiana, from the year 1668 to the present time. (3 Vols.). Georgetown: J. Thomson, p. 3 . 
The first depot was established in the Pomeroon

district in $1580 .^{5}$ From this base, expeditions were mounted into the interior in search of Amerindian trade, as well as gold and silver. It was the lure of gold that brought sir Walter Raleigh to Guyana's shores in 1595 in his quest for El Dorado, the mythical city of gold. Raleigh was so enamored of the country that he constituted a plan of a huge English empire extending from the Amazon to the orinoco. On his return to England, he published his book "The Discoverie of Guiana," in which he gushed:

Guiana is a country that hath yet her maidenhead, never sacked, turned, nor wrought, the face of the earth torn, nor the virtue and salt of soil spent by manuarance, the graves not been opened for gold, the mines not broken wi.th sledges...

Those commanders and chieftains, that shoot at honour, and abundance, shall find here more rich and beautiful cities, more temples adorned with golden images, more sepulchres filled with treasure, than either cortez found in Mexico, or Pizzarro in Peru..

I never saw a more beautiful country, nor more likely prospects, hills so raised here and there over the val.leys, the river winding into divers branches, the plains adjoining without bush or stubble, all fair green grass, the ground of hard sand easy to march on, either for horse or foot, the deer crossing in every path, the birds towards the evening singing on every tree with a thousand different tunes, cranes and herons of white crimson and carnation perching on the river's side, the air fresh with a gentle easterly wind, and every stone that we stopped to take up promised either gold or silver by his complexion. ${ }^{6}$

${ }^{5}$ Ibid.

${ }^{6}$ Raleigh, Sir Walter. 1966. Discoverie of Guyana. In New World (Guyana Independence Issue), Georgetown: New World Group Associates, p. 21. 
Raleigh's flight of fancy was more than enough to excite countless adventurers to Guyana's shores. The expenditure of lives, energy, and capital was immense, on what was essentially a blatant prevarication.

The Spaniards who had claims to Guyana immediately evicted the Dutch from their fledgling Pomeroon settlement in $1596 .^{7}$ Undeterred, the evicted settlers moved to an island at the junction of the Essequibo, Mazaruni, and Cuyuni Rivers, where they established Fort Kijkoveral (literally, "see-over-all") some thirty miles inland. The settlers' territorial claims were bolstered in 1609 when Hugo Grotius, a Dutch international jurist, published his "Mare Libirum" denouncing Spanish claims of rights to the seas and a monopoly of trade with the Caribbean. ${ }^{8}$ Propped by Grotius' treatise, the settlers organized smaller trading posts deep in the interior of the country. Even the Pilgrim fathers toyed with the idea of settling in Guyana in 1620 before prevailing upon the North American continent. To invigorate the Guyana trade, the Dutch granted a charter to a group of merchants who established the Dutch West India Company (DWIC) in 1621. The DWIC was allotted exclusive control over all the area and settlements along

${ }^{7}$ Great Britain. Colonial office. 1960. Annual Report on British Guiana. London: H.M.S.O., p. 218 .

${ }^{8}$ Report of the United States Commission on the Boundary between Venezuela and British Guiana. 1897. Washington, D.C.: Government Printing office, p. 9. 
the Eastern American and West African seaboards from the Tropic of Cancer to the Tropic of Capricorn. Besides engaging in commerce, the DWIC was also authorized to plunder Spanish and Portuguese vessels, and to exercise its monopoly over the African slave trade to secure a supply of cheap labor for its settlements on the American continent. In 1627, the DWIC issued a license to Abraham van Pere, a Dutch merchant, to settle on the Berbice River. Van Pere brought sixty male settlers with him to Berbice, where they built Fort Nassau, roughly fifty-five miles up the Berbice River. ${ }^{9}$ Berbice was allowed to operate as a separate colony from Essequibo, with its own civil and criminal jurisdictional privileges. Van Pere was assigned the title of "patroon" and he and his fellow colonists had the right "to do all...things which they shall judge good and profitable for their colony..."10 Despite the apparent wide-ranging powers allotted to van Pere, the DWIC placed restrictions on internal development and fostered dependence by stipulating a number of restrictive conditions. For example, under the conditions van Pere signed with the DWIC on June 12,1627 :

The Company [i.e., DWIC] shall transport all the necessaries of the colonists, their arms, and agricultural implements, likewise their provisions ...The Colonists shall not trade with any other nation, or transport their goods by any other than

${ }^{9}$ Great Britain. Colonial office 1960, op. cit., p. 218.

${ }^{10}$ Report of the U.S. Commission 1897, op. cit., p. 47. 
the company's vessels... The colonists shall not manufacture any woolen, linen or cotton, or weave any other clothing materials, on pain of being prosecuted for perjury...All merchandise and products of the colony shall be sent by the Company's vessels. ${ }^{11}$

Economic growth, as a result, was painfully slow in both colonies.

The Berbice colony, like its sister colony of Essequibo, was committed to trading pursuits. The colonies were seen to be little more than trading outposts. Each colony would annually receive a ship laden with merchandise, and it was customary for each ship's captain to accept control of one of the colonies whilst his forerunner would return to Holland with the previous year's commodities. ${ }^{12}$ The profits were particularly meager, and little was done to promote the development of the settlements.

In 1664 Major John Scott took Essequibo for the British. The occupation was for only a few short months, but it highlighted Guyana's fragile position in Europe's struggle for commercial and political dominance. It was a measure of the country's robustness that just four after the

"Rodway, J. and T. Watt. 1888. Chronological History of the Discovery and settlement of British Guiana, 1493-1796. Georgetown: Royal Gazette, pp. 97-98.

${ }^{12}$ Rodway 1891, op. cit., vol. I, p. 4. 
war, 60,000 pounds of sugar and 20,000 pounds of letterwood were exported to Holland. ${ }^{13}$

Upriver locations were the most desirable sites, but despite the colonists' precautions, they could not escape the fact that they were part of an inextricably connected system in which European rivalries dictated events. 1708 witnessed the pillage of the Essequibo colony. French privateers led by Captain Antoine Ferry forced the colony to surrender and extracted a ransom of 50,000 guilders from the settlers.14 The following year the Essequibo colony was visited by two more French privateers, who sacked and destroyed four of the DWIC's plantations and a good number of the private ones. After they had departed, only two sugar mills were said to be in operation. ${ }^{15}$ Essequibo's sister colony of Berbice suffered a similar fate in 1712 when it was plundered by another group of French privateers. A ransom of 300,000 guilders was levied on the House of van Pere, but the local commander was unable to satisfy the demand. A bill of exchange was drafted and taken to Holland, where it was paid off by a syndicate of merchants led by Nicolas van Hoorn. After nearly a century, the van

\footnotetext{
${ }^{13}$ Netscher, P. 1888. History of the Colonies, Essequibo, Demerara and Berbice. Tr. W.E. Roth. Reprinted, Georgetown: Daily Chronicle, 1929, p. 37.

${ }^{14}$ Daly, V.T. 1975. A Short History of the Guyanese People. London: Macmillan, p. 66 .

${ }^{15}$ Rodway 1891, op. cit., vol. I, p. 53.
} 
Peres' association with Berbice had finally come to an end. ${ }^{16}$ Despite these setbacks, both Essequibo and Berbice rebounded quickly. The resilience of the colonies was partly a reflection of the impressive economic potential of the territory.

Meanwhile, in the colony of Berbice, the colonists in 1723 had begun a movement of another kind. No longer under the leadership of the van Peres' they fought the DWIC to allow trade with North America. The North American trade gave a fillip to the burgeoning Fort Nassau settlement, as it provided the settlers with desperately needed livestock and a market for their own products. They were, however, prevented from completely breaking dependence on Holland, being required to export their more lucrative commodities such as sugar, cotton, coffee, and tobacco - to the home country. ${ }^{17}$

Sugar was not the only crop in production; cotton and annatto were regularly being exported. Coffee did not reach Essequibo until 1725, when 30,000 plants were imported from Surinam and planted in the neighborhood of Kijkoveral. ${ }^{18}$ Export figures lend support to the widening of the export base. In 1764 Essequibo, and the newly opened Demerara

\footnotetext{
${ }^{16}$ Daly 1975, op. cit., p. 66.

${ }^{17}$ Dalton, H.G. 1855. The History of British Guiana.
} London: Longman, Brown, Green \& Longman, p. 187.

${ }^{18}$ King, K.F.S. 1968. Land and People of Guyana. Oxford: University of Oxford, p. 38 . 
region, exported 2,956 hogshead of sugar, 31 barrels and 211 bags of coffee, and 2 bales of cotton, whilst in 1766 we find 4,120 hogshead of sugar, 37 barrels and 2,532 bags of coffee, and 101 bales of cotton being shipped to Europe. ${ }^{19}$ Economic progress in the colonies was hampered by the short-sighted policies of the directors. They were primarily interested in repatriating profits into their mercantile houses in Europe. Accordingly, they instituted orders which prohibited shipping and trade with all foreign countries except Holland.

Each plantation was a self-contained unit, with little or no internal linkages with the domestic plantation economy. External orientation meant that each plantation kept its own boat or other vessel for the transhipment of its produce to metropolitan ships anchored off shore. ${ }^{20}$ Dr. George Pinckard, a physician to the British armed forces in the final decade of the eighteenth century, disclosed:

There be no market in the colony, each planter's abode must furnish all within itself, every necessary, every comfort, all that is given, or enjoyed, must be found in the house or upon the plantation. ${ }^{21}$

${ }^{19}$ Rodway 1891, op. cit., vol. I, p. 221 .

${ }^{20}$ St. Clair, T.S. 1947. A Soldier's Sojourn in British Guiana, 1806-1808. Edited by V. Roth. Georgetown: Daily Chronicle, p. 29 .

${ }^{21}$ Pinckard, G. 1942. Letters from Guiana. Extracted from Notes on the West Indies and the Coast of Guiana. Ed. V. Roth. Georgetown: Daily Chronicle, p. 95. 
Lines of internal communication were neglected. The colonies remained dependent, little more than appendages to the metropolis, devoid of all forms of association with neighboring colonies.

International geopolitical rivalries during the American War of Independence plunged Britain and Holland into direct conflict, and in 1781 the British captured Essequibo, Demerara, and Berbice. ${ }^{22}$ For the first time the three colonies were controlled as a single entity. Lieutenant colonel Kingston was entrusted the reins of government and in a relatively short time opened the colonies to British settlers. British rule was short-lived, for in 1782 the colonies were seized by the French, with whom the British were also at war. The compte de Kersaint assumed the post of governor of the three colonies and began vigorously undertaking a variety of settlement projects, including the creation of a new town - Longchamps, at the mouth of the Demerara River. A measure of free trade was encouraged and, according to a French census, authorized by Kersaint; the colonies were in a healthy position. Plantations in the three colonies totalled 387 , whilst exports stood at 500,000 francs annually. ${ }^{23}$

Despite their high civic-mindedness, French rule was unpopular; settlers disliked the increase in taxes

\footnotetext{
${ }^{22}$ Dalton 1855, op. cit., p. 238.

${ }^{23}$ Goslinga 1985, op. cit., p. 437 .
} 
considered necessary to underwrite all of Kersaint's projects. As a result, many were thankful when the colonies were restored to the Dutch at the Treaty of Versailles in $1783 .{ }^{24}$

In the aftermath of the geopolitical chess games of the early 1780s, it was generally accepted that Demerara was the most advanced of the three colonies. The Dutch sought to consolidate Demerara and Essequibo with the transfer of the seat of government for both colonies to Demerara. Longchamps, now renamed stabroek, was chosen to be the capital. The move appears to have been a good one, because by the end of the decade, exports of coffee, cotton, and sugar were all in ascendancy. ${ }^{25}$

The DWIC, besieged with problems, did not share in the colony's good fortune. It was an anachronism; its organization and methods were more suited to the days of raiding and plundering. Constrained by a restricted monopolistic corporate culture and unable to attract good personnel to its colonies, the company wound up its affairs in 1792 and passed control of Demerara and Essequibo to the Dutch government. ${ }^{26}$ The downfall of the company provided a fillip to the plantation economy of Demerara and Essequibo. Investor confidence was bolstered and the restrictions on

\footnotetext{
${ }^{24}$ Dalton 1855, op. cit., p. 239.

${ }^{25}$ Rodway 1893, op. cit., vol. II, p. 57.

${ }^{26}$ Ibid. , p. 60.
} 
the importation of African slaves revoked. Settlers were now allowed to trade with neutral vessels, and in 1795 this trade was extended to include commodities which were once confined solely to the Dutch markets. Trade with the Americas was the biggest gainer in the new alignment. Cotton exports increased from $1,000,000$ in 1793 to 3,000,000 pounds in 1794 , and sugar from $3,000,000$ pounds to an impressive 10,000,000 pounds. Coffee, however, registered a slight decline, falling from 5,000,000 million pounds in 1793 to 4,000,000 pounds in 1794. Berbice's exports in 1794 were also striking, with sugar totalling 1,000,000 pounds, cotton 190,000 pounds, and coffee 2,000,000 pounds. ${ }^{27}$

Hostilities broke out between the Dutch and English in 1796, and the colonies once again fell into the hands of the British. ${ }^{28}$ The capitulation was made on generous terms, with the inhabitants being guaranteed "their ancient laws and usages." 29 The transition to British rule failed to hinder the economic expansion engendered over the previous twenty years. Indeed, development was intensified as additional British capital found its way to Guyana. ${ }^{30}$ The

${ }^{27}$ Thompson 1987 , op. cit., p. 63.

${ }^{28}$ Rodway, J. and J. Stark. 1895. Stark's Guide-Book and History of British Guiana. Boston: Stark Publisher, p. 20 .

${ }^{29}$ Dalton 1855, op. cit., p. 243-244.

${ }^{30}$ Schomburgk, Robert. 1840. A Description of British Guiana, Geographical and Statistical: Exhibiting its Resources and Capabilities, Together with the present and Future Condition and Prospects of the colony. London: Simkin, 
newly available capital meant that a much larger area of land could be empoldered. Many Dutch landowners sold out to the British and left. Guyana was being drawn tighter into a world system dominated by British interests and markets.

Although sugar, coffee, and cotton all showed signs of export-increases, it was cotton that benefitted the most in the early years of British rule. There is some speculation that it was the cotton lobby in Great Britain which pressured the British government to retake Guyana so that mills in the north of England would be assured of a supply of cotton. ${ }^{31}$ The spinoff of the trade was the growth of many industrial towns in Britain. Bristol, Liverpool, Manchester, and Glasgow all profited from the increased activity; and many other ports, including London, served as important distribution centers.

High prices for sugar at the turn of the nineteenth century increased sugar production on a world scale. Cuba entered the market as a major exporter, and the sugar-beet industry in Europe had just begun to take off on a large scale. The resulting overproduction on the world market soon sent prices into a downward spiral. ${ }^{32}$ In Guyana the cry of "ruin" echoed around the plantations of the onceprosperous industry. However, the overall effect on the

Marshal1. Reprinted, London: Frank Cass, 1970, p. 61.

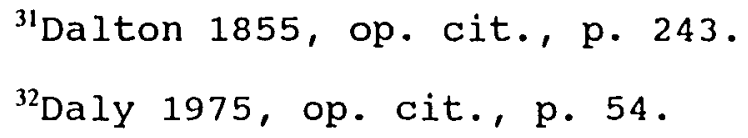


Guyanese economy was not entirely disastrous. The success of Guyanese cotton and coffee in the British market served to dampen the overall effects of a potential depression. The event did, however, shine a light on future dependency relations and the likely consequences of relying on a narrow range of exports.

With the transfer of political control, dependence on Holland was quickly replaced by a dependence on Britain. This shift can be illustrated by the number of British ships plying Guyanese waters during the latter part of the eighteenth century. In 1797, 197 ships visited EssequiboDemerara, with the figure rising to 285 in $1800 .{ }^{33}$

Meanwhile, Berbice witnessed the arrival of 32 British ships in 1797 and 94 in $1798 .{ }^{34}$ The considerably lower number of ships trading with Berbice was a reflection of the colony's decline relative to that of Essequibo-Demerara. Another possible reason for the dearth of ships may have been related to the shallowness of the river. Larger ships had severe difficulties navigating the sandbars associated with the Berbice and Essequibo Rivers. The Demerara had thus developed as a transhipment point catering to ships from the other two rivers. Van Batenburg, the Governor of Berbice, saw the danger of the practice to his colony, believing that

\footnotetext{
${ }^{33}$ Thompson 1987, op. cit., p. 64.

${ }^{34}$ Ibid.
} 
the spillover trade to Demerara would eventually be very detrimental to Berbice. ${ }^{35}$

Between 1799 and 1801 exports to Great Britain witnessed a threefold increase. For plantation owners, the links to Great Britain were proving to be quite profitable. However, on March 25, 1802, political developments in Europe sent shock waves throughout the plantation community in Guyana. The signing of the Treaty of Amiens restored Essequibo, Demerara, and Berbice to the Dutch. ${ }^{36}$ The new Dutch authorities at once ordered the British planters to give up their properties and vacate the country. ${ }^{37}$ Land values which had been appreciating during the six years of British rule began a rapid decline. Dutch creditors who had extended loans to planters during the previous Dutch administration flocked to Guyana demanding compensation now that the country was once again flying the Dutch flag. The British, in 1796, had forced planters to sever their connections with Dutch mercantile houses. Many had therefore turned to British financial houses in Bristol, Liverpool, Manchester, and London to garner the resources required to establish plantations in Guyana. In desperation, the planters and their lobby in Great Britain

\footnotetext{
${ }^{35}$ Ibid., p. 66 .
}

${ }^{36}$ Webber, A.R.F. 1931. A Centenary History and Handbook of British Guiana. Georgetown: Argosy, p. 122 .

${ }^{37}$ Dalton 1855, op. cit., p. 259. 
waged a campaign for the restoration of British rule. Their appeals quickly bore fruit, and on september 19, 1803, a naval squadron led by Commodore Hood and General Grinfield captured Demerara and Essequibo for the British. ${ }^{38}$ Five days later Berbice also was forced to surrender. Once again the terms of capitulation were extremely generous. Lieutenant Colonel Robert Nicholson was appointed acting Governor of the United Colony of Demerara and Essequibo, and of Berbice. In the language of world systems analysis, the call for British intervention was simply an attempt to control the vagaries of the sugar market by encouraging capitalist penetration and the peripheralization of Guyana.

The Dutch officially ceded to the British all territorial claims to the colonies in $1814 . .^{39}$ The final passing of the colonies into British hands guaranteed a large measure of political security to the British planter class in the colony. Their economic security had been fostered earlier in 1812 by a moratorium on Dutch creditors. ${ }^{40}$ The future appeared to be bright in spite of the abolition of the slave trade in 1807 .

The union of Berbice, and Demerara and Essequibo finally took place in 1831. The merger into the single

${ }^{38}$ Ibid. , p. 26.

${ }^{39} \mathrm{Clementi,} \mathrm{Sir} \mathrm{Cecil.} \mathrm{1937.} \mathrm{A} \mathrm{Constitutional} \mathrm{History} \mathrm{of}$ British Guiana. London: Macmillan, p. 30 .

${ }^{40}$ Ibid. , p. 50 . 
colony of British Guiana had been long in coming. On the grounds of economy, the British had long felt that Berbice did not warrant a separate governor and its own retinue of civil servants. Proprietors of the plantations now began to leave Guyana, preferring to return to Britain to flaunt their newly acquired wealth. ${ }^{41}$ Social status and acceptance in the metropolis were being eagerly sought to complement the planters' newfound affluence. Some sought entry into the landed gentry class, whilst others, who perhaps were more socially advanced, used their wealth to buy titles back home. Unlike the British, the Dutch planter regarded Guyana as his home. Plantations were individually owned and administered - the planter solely in charge of all plantation matters including planting, harvesting, shipping, marketing, and finance. Some of the early British planters were also of the Dutch mold, but as the sugar industry began to assume greater importance a new class of owners became prevalent. These absentee owners were much wealthier than their predecessors; they resided in England, while the affairs of their estates were turned over to attorneys who managed the properties for a percentage, usually between five and ten percent of the estates' net profits. In 1817 roughly one-half of all the estates in the country were in

\footnotetext{
${ }^{41}$ Dalton 1855, op. cit., p. 319.
} 
the hands of attorneys. ${ }^{42}$ Attorneys for the most part resided in Georgetown and were often members of the most influential commercial houses in the city, ${ }^{43}$ a fact which exemplifies the close association between the plantocracy and the merchant class in nineteenth-century Guyana.

Ensconced in their homeland, the absentees frittered away the surpluses derived in Guyana. Very little money made its way back to the colony. Since proprietors did not reside in Guyana, they had little interest in the development of the colony. As long as profits could be made quickly and without hindrance, little thought was given to internal development. Guyana was but an agricultural periphery of the British, its population dependent on approximately 200 proprietors who owned all the land in cultivation, of whom only about 75 were domiciled in the country. ${ }^{44}$

Surpluses were siphoned out of Guyana on such a scale that there was no requirement for financial facilities in the colony. During Dutch rule a bank was established in Amsterdam to advance money to proprietors in the country. ${ }^{45}$

${ }^{42}$ Ragatz, L. 1928. The Fall of the Planter Class in the British Caribbean, 1763-1833. London: Oxford University Press, p. 303 .

\footnotetext{
${ }^{43}$ "Landowner" 1853. British Guiana; Demerara after Fifteen Years of Freedom. London, p. 36
}

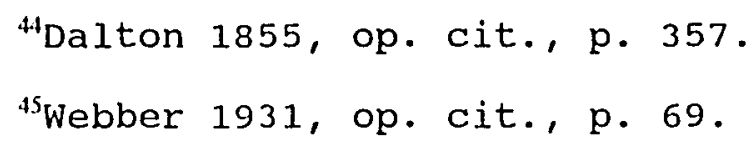


This meant that all financial transactions took place abroad, with capital formation strictly the preserve of the metropole. The first domestic bank did not open its doors until February 16, 1837, when the British Guiana Bank commenced business. ${ }^{46}$

\section{INDUSTRIAL STRUCTURE}

Attention now turns to the country's industrial structure. Agriculture constituted the main productive base of the economy, and this section follows the development of the three most important crops - sugar, coffee, and cotton in light or their infiluence on settlement configurations.

In 1621, Kijkoveral became the administrative center of the Dutch colony. Some small-scale cultivation of vegetables ${ }^{47}$ was undertaken at Cartabo Point, a short distance from Kijkoveral; but since the DWIC was chiefly concerned with trade and not colonization, scant attention was paid to agriculture. Crops were planted only as a supplement to the food supply for those in employ at the fort.

Increasingly, however, the Dutch found agriculture to be a rewarding activity. Tobacco proved to be a profitable cash crop, and the first Guyanese plantations were devoted to this commodity. It was only later that sugar cane was

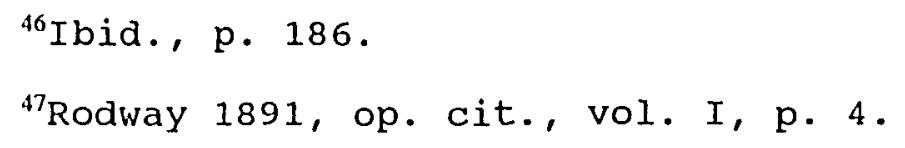


introduced as a cash crop to satiate the growing European demand for sugar. ${ }^{48}$ For instance, whilst Essequibo was able to send 28,000 pounds of tobacco to Holland as early as 1623 it was not until 1636 that sugar cane cultivation commenced in the vicinity of Kijkoveral. ${ }^{49}$ The Dutch introduced the Arab type of sugar cane to Guyana, and by 1637 they had sent two kegs of syrup to Holland to be reduced into sugar. ${ }^{50}$

In 1656 the DWIC published prospectuses which presented exaggerated accounts of the wealth that could be achieved by cultivating sugar cane in Guyana. To sweeten its inducement, the company offered potential Dutch colonists grants of land and the opportunity to purchase slaves on favorable terms. ${ }^{51}$ settlers streamed into the colony; many were Dutch and Portuguese Jews from Brazil who sought religious freedom under Dutch rule. ${ }^{52}$ They brought with them a technical proficiency in sugar, which greatly assisted the development of the industry in Guyana. Most of the Brazilian colonists brought their slaves with them and

${ }^{48}$ Rodway, J. 1912. Guiana: British, Dutch and French. London: T. Fisher, Unwin, p. 230.

${ }^{49}$ Jeffrey, H. and C. Baber. 1986. Guyana: Politics, Economics and Society: Beyond the Burnham Era. Boulder, Colo.: L. Rienner, p. 10 .

${ }^{50}$ Shahabuddeen, M. 1983. From Plantocracy to Nationalization: A Profile of Sugar in Guyana. Georgetown: University of Guyana, p. 11.

${ }^{51}$ Rodway and Watt 1888 , op. cit., p. 136.

${ }^{52}$ Daly 1975, op. cit., p. 43. 
settled on the Pomeroon River, in Essequibo, where they began the first large-scale cultivation of sugar cane in the country. ${ }^{53} \mathrm{~A}$ number of plantations were also established adjacent to Kijkoveral and on the west bank of the Essequibo River. ${ }^{54}$ Rapidly sugar cane began replacing tobacco as the main crop cultivated in the country. However, Essequibo and Berbice remained overwhelmingly trading posts, reflecting the colonizers' desire for quick profits.

The first sugar mill was introduced into Guyana during 1664.55 Established in Essequibo at Plantation Brouwersboek, in the vicinity of Kijkoveral, the mill was driven by horses; the horse-driven method greatly outperformed the previous manual method of crushing canes with two rollers. The advances in the industry soon caught the attention of the governor of the neighboring British colony of Surinam, who in 1665 declared Guyana to be the greatest Dutch colony in all of the Americas. ${ }^{56}$ And by 1670 the Essequibo colony could boast three company plantations with approximately fifty-eight slaves on them. Berbice too

\footnotetext{
${ }^{53}$ Ibid. , p. 48 .
}

${ }^{54}$ Netscher, P. 1888. History of the Colonies, Essequibo, Demerara and Berbice. Tr. W.E. Roth. Reprinted, Georgetown: Daily Chronicle, 1929 , p. 34.

${ }^{55}$ Bronkhurst, H.V.P. 1890. A Descriptive and Historical Geography of British Guiana and West India Islands. London, $p$. 54 .

\footnotetext{
${ }^{56}$ Clementi 1937, op. cit., p. 17.
} 
was improving, and in 1672 five sugar estates were in cultivation in the colony. ${ }^{57}$

In 1720 five sugar mills were already operating in Essequibo, 58 whilst Berbice began to lay out its first coffee plantations in $1721 .{ }^{59}$ Essequibo's and Demerara's economic success largely rested upon "King sugar." Gravesande in 1750 proclaimed that it was virtually the only crop of any import. ${ }^{60}$ No doubt sugar's high price during the Seven-year War (1756-63) in Europe provided some impetus towards its cultivation. The coastal fringes, however, were considered too saline for sugar cane, whilst cotton proved to be ideally suited to the conditions. ${ }^{61}$ Sugar's domination of the plantation economy was thus postponed and some measure of diversification assured, albeit only temporarily.

Much of the increase in agricultural development has been attributed to the influx of English planters from Antigua, Barbados, and other west Indian islands where soils were overworked and exhausted. ${ }^{62}$ Gravesande observed in

${ }^{57}$ Van Berkel, A. 1941. Adrian van Berkel's Travels in South America Between the Berbice and Essequibo Rivers and in Surinam, 1670-1689. Georgetown: Daily Chronicle, p. 95.

\footnotetext{
${ }^{58}$ Netscher 1888 , op. cit., p. 46.

${ }^{59}$ Webber 1931, op. cit., p. 28.

${ }^{60}$ Daly 1975, op. cit., p. 77.

${ }^{61}$ Dalton 1855, op. cit., p. 224.

${ }^{62}$ Netscher 1888 , op. cit., p. 53.
} 
1760 that the English were in a majority in Demerara, ${ }^{63}$ but according to Goslinga ${ }^{64}$ only one-third of the plantations were owned by citizens of the United Kingdom. It is possible that some of the English immigrants may have acted as attorneys or managers for Dutch-owned plantations. ${ }^{65}$

Agricultural production in Demerara continued to improve. ${ }^{66}$ Nevertheless, with a greater: quantity of land under cultivation, Essequibo's production continued to outperform that of its rival. ${ }^{67}$ Berbice similarly had witnessed increased production, ${ }^{68}$ but the colony's progress was hampered by the short-sighted policies of its directors.

The slave uprising of 1763 was another blow which befell Berbice. ${ }^{69}$ It took an additional six years before the colony was able to reach the production figures it had achieved in 1749. Berbice failed to recover from the

${ }^{63}$ Harris, C. and J. Villiers. 1911. Storm van's Gravesande: The Rise of British Guiana. London: Hakluyt Society, p. 68 .

${ }^{64}$ Goslinga 1985, op. cit., p. 447.

${ }^{65}$ Smith, R.T. 1962. British Guiana. London: Oxford Univ. Press, p. 16.

${ }^{66}$ Rodway 1891, op. cit., vol. I, p. 230.

${ }^{67}$ Ibid. , p. 139 .

${ }^{68}$ Thompson 1987 , op. cit., p. 41.

${ }^{69}$ Rodway (1892:174) is "unsure of t the causes"; Webber (1931:59) attributes the uprising to the "cruelties of the planters"; whilst Daly (1975:143) suggests that the major causes were a shortage of provisions, cruel treatment, injustice, and an indomitable spirit of freedom. 
catastrophe, forever assuming the role of a poor cousin to Demerara.

Plantation cultivation was devoted mainly to coffee and sugar in Essequibo and Demerara. In Berbice, on the other hand, cultivation was almost exclusively restricted to coffee and cotton. ${ }^{70}$

Cotton production increased from 1,079,325 pounds in 1793 to $3,054,757$ in 1794 , and sugar from 3,187,000 pounds to an impressive 10,063,829 pounds (Table I). Coffee, however, registered a slight decrease, falling from $5,388,030$ pounds in 1793 to $4,475,605$ pounds in 1794 . Berbice's production in 1794 were equally impressive, with sugar amounting to $1,116,800$ pounds, cotton 194,889 pounds, and coffee $2,762,264$ pounds. ${ }^{71}$

TABLE I

COMPARATIVE PRODUCTION OF SUGAR, COFFEE AND COTTON, ESSEQUIBO AND DEMERARA 1793-17S8

Year Sugar (lbs) Coffee (1bs) cotton (1bs)

$1793 \quad 3,187,000 \quad 5,388,030 \quad 1,079,325$

$1794 \quad 10,063,829 \quad 4,475,605 \quad 3,054,757$

$1798 \quad 6,427,162 \quad 6,730,210 \quad 3,158,886$

Source: Thompson 1987, p. 63 .

Although the export-import sphere constituted the primary focus of the plantation economy in Guyana, this

\footnotetext{
${ }^{70}$ Williams, J.F. 1950. "The Development of the Cane Sugar Industry in British Guiana." Timheri 29, p. 124.

71Thompson 1987, op. cit., p. 63.
} 
domain was complemented by a subsistence sector. This sector did not become firmly entrenched in Guyana until the American War of Independence, when sizeable supplies of consumption goods were cut off from the Guyanese market. This led to the emergence of subsistence production and marketing, which contained the impetus for the subsequent growth of a free peasantry, potentially antithetical to the dominant plantation mode.

The peasant marketing system was dominated by free persons of color and slaves who also participated. These people operated through a system of local "huckster" markets, which supplied the plantations and free citizens with a variety of foodstuffs. Hucksters were commercial intermediaries, often women, who travelled about the countryside buying produce from small farmers for resale at the nearest market or collection point. Despite the acknowledged importance of this sector, production for the home market accounted for only a fraction of the total. agricultural output. There was still an overwhelming dependence upon imported consumption goods. The success of subsistence production and marketing as a source of independent income for the enslaved and freed population generated considerable anxiety among the planters. As a result, they promulgated a series of laws which proscribed the economic activities of the enslaved population. For example, in 1793 the Court of Policy prohibited slaves from 
selling a wide range of commodities, whilst their masters' written permission was required for the sale of other goods. The Guyanese coast appeared to be an idyllic location for the cultivation of the salt-tolerant sea-island type of cotton. Cotton cultivation on the coast immediately took root, for in 1796 Dr. Pinckard observed:

The estates now in cultivation upon the seacoast, from the Demerara river to the boundary of the colony of Berbische, are one hundred and sixteen; all producing cotton except the "Kitty" ... which has been recently planted with sugar... It is scarcely necessary to remark that coffee, cotton, and sugar are the great, and almost only commercial productions of the colony. ${ }^{72}$

Cotton plantations were also established along the banks of the Mahaica and Mahaicony Creeks. ${ }^{73}$ Coffee estates were to be found on both banks of the Demerara river, including those on which present-day Georgetown is located, along the banks of Canals Nos. 1, 2, and 3, and on Demerara's west coast. ${ }^{74}$ As the eighteenth century drew to a close, Guyana was said to be the world's "greatest cotton producer and the greatest coffee grower in the British empire."75 Sugar's hegemony was broken, and cotton temporarily surpassed it as the principal staple from

\footnotetext{
${ }^{72}$ Pinckard 1942, op. cit., p. 330.

${ }^{73}$ Dalton 1855, op. cit.; p. 248 .

${ }^{74}$ Rodway 1893, op. cit., vol. II, p. 93.

${ }^{75}$ Adamson, A.H. 1972. Sugar Without Slaves: The Political Economy of British Guiana. New Haven: Yale University Press,
} p. 25 . 
Demerara and Essequibo. Whilst sugar's reversal of fortune could be attributed to economic forces set in motion in the core, it should be recalled that the planters generally believed that the saline coastlands of Guyana were unsuitable for the cultivation of sugar cane. By 1798, sugar production in Demerara-Essequibo had declined to $6,427,162$ pounds, whilst cotton and coffee production had increased to $5,158,886$ pounds and $6,730,210$ pounds, respectively. In the same year, Berbice experienced a mini coffee boom with a production figure of $8,989,460$ pounds. Cotton also increased its market share by posting a record production of 791,526 pounds. ${ }^{76}$

The nineteenth century opened with a general sense of optimism in Guyana. Although sugar production had experienced some setbacks, its decline in Guyana was a relative rather than an absolute one. The general prosperity in the country was evident, so much so that Dalton referred to the period as a "Golden Age." A combination of British capital and slave labor resulted in a total of 490 estates stretching along the Guyanese littoral, from the Pomeroon to the west bank of the Corentyne River. ${ }^{77}$ There was a general increase in the major staples, and production in 1801 were nearly triple those in 1799 (Table II) .

\footnotetext{
${ }^{76}$ Thompson 1987 , op. cit., p. 63.

${ }^{77}$ Pinckard 1942, op. cit., pp. 184-185.
} 
TABLE II

COMPARATIVE PRODUCTION OF SUGAR, COFFEE AND COTTON, ESSEQUIBO, DEMERARA AND BERBICE 1797-1802

Year sugar (lbs) Coffee (1bs) Cotton (1bs)

1797

1799

1801

1802

$$
4,320,155
$$

$3,717,216$

$10,643,504$

$17,520,000$
$12,001,063$

$4,378,030$

$15,995,760$

$11,539,497$
$2,907,798$

$3,593,053$

$7,662,942$

$7,623,900$

Sources: Rodway 1921, p. 294; Daly 1975, p. 102.

Agricultural production registered a slight hiccup when the colonies were returned to the Dutch in 1802 , but with the Link to Britain restored, following the British invasion in 1803, Guyana's industrial structure was relatively diversified. Sugar's hold on the economy had been challenged by cotton and coffee, which were being successfully cultivated along the fertile alluvial coast. The prosperity derived from these three major export crops indicated that the economy was robust. A change in the industrial structure of the economy was set in motion by the abolition of the slave trade in 1807 . The results of Parliament's fateful decision in London was not immediately felt on the estates in Guyana. Naturally, the price of slaves rose considerably, but the structure of the economy initially remained intact. It was not until around 1810 that cracks in the economy became noticeable. Cotton and coffee were the greatest losers in the new system. Cotton's 
decline was attributed mainly to competition from the American cotton industry. ${ }^{78}$ American produrers with their greater efficiency and lower production costs flooded the world markets. Guyanese planters failed to compete and subsequently declined.

Coffee's pre-eminence in Guyana and the world market was quashed by competition from Brazil and by the "continental system," operated by the British, that restricted Guyanese planters' access to the lucrative American market. ${ }^{79}$ The weakening of coffee and cotton resulted in sugar becoming the dominant crop of the plantation economy. Some of the abandoned estates were converted into sugar estates, and a few were turned into cattle farms. ${ }^{80}$ The coastal transition to sugar was made possible because of the decrease in the salt content of the soils, a situation brought about by European agricultural practices which had rendered the soil open to rain, thereby allowing the salt to leach away. Between the years 1809 and 1824 a total of 111 cotton plantations were abandoned, 14 of which, were subsequently converted into sugar. Twenty-one coffee estates went out of business, and five of these were replaced by sugar. ${ }^{81}$

\footnotetext{
${ }^{78}$ Dalton 1855, op. cit., p. 327 .

${ }^{79}$ Adamson 1972, op. cit., p. 25. 
The production data also illustrates the three export staples' reversal of fortunes (Table III). In 1810, Demerara and Essequibo produced 9.2 million pounds of sugar, 19.2 million pounds of coffee and 5.8 million pounds of cotton; in 1814, sugar increased to 31.3 million pounds, whilst coffee output fell to 8.3 million pounds and cotton rose to 6 million pounds. By 1824, coffee production dropped to 4.7 million pounds and cotton to 1.9 million pounds; conversely, sugar continued its recovery and production now stood at 34.9 million pounds.

\section{TABLE III}

COMPARATIVE PRODUCTION OF SUGAR, COFFEE AND COTTON, ESSEQUIBO AND DEMERARA 1810-1824

(MILLIONS OF POUNDS (LBS))

Year

1810

1814

1824

Sources: Rodway 1893 (Vol II), p. 214 ; Webber 1931, p. 141..
31.3

34.9
8.3

4.7

\section{cotton}

5.8

6.0

1.9 
windmill. ${ }^{82}$ However, planters quickly discovered that although sea breezes were adequate for the most part, oftentimes at critical points in the manufacturing process there would be insufficient wind to power the mills. Thus, the introduction of the first steam engines in 1805, to power the mills on plantations Belle vue and Hague, was a major event in the history of the sugar industry in Guyana. ${ }^{83}$ Steam power became the major motive force, and by 1829 the horizon was reported to be dotted with chimney stacks. ${ }^{84}$

Guyana's international competitiveness in sugar was alsu aided by its late arrival as a major west Indian producer. Consequently, planters were able to adopt new technological innovations much more quickly than their Caribbean counterparts. Guyana also benefitted from specific geographical factors which made it possible to cultivate and harvest two sugar crops annually. As a result, machinery and capital equipment could be used more intensely, and for longer periods of the year, than elsewhere. ${ }^{85}$

Despite all the forecasts of doom and destruction that would follow emancipation, the transition was noticeable for

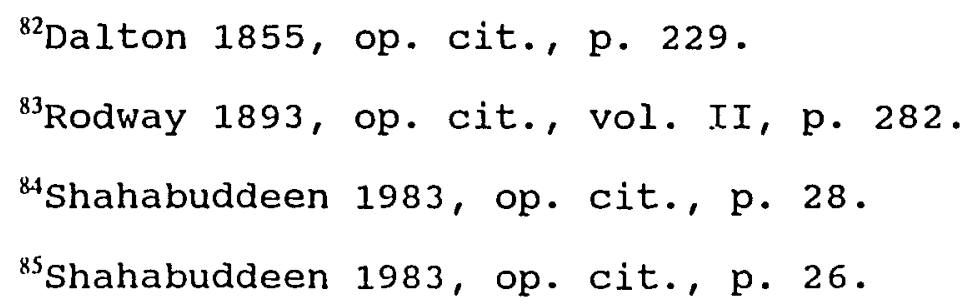


its relative calm. Apprenticeship, from the planter's circumscribed economic viewpoint, could be declared something of a triumph for king sugar. Sugar production actually increased for the period 1834-38; coffee also witnessed a slight increase, though cotton declined appreciably (Table IV).

TABLE IV

COMPARATIVE PRODUCTION OF SUGAR, COFFEE AND COTTON, GUYANA 1833 - 1838

(MILLIONS OF POUNDS (LBS))

Year

Sugar

Coffee

Cot.ton

1833

1834

1835

1836

1837

1838

99.1

81.1

107.6

107.8

99.8

88.7
4.5

3.0

3.1

5.9

4.1

3.1
0.9

0.9

0.8

0.6

0.8

0.6

Source: Blue Books 1833-38.

Obviously, apprenticeship failed to hinder the growth of the plantation economy. Planters were able to weather the storm by successfully adapting to the new system. Aided by a guaranteed supply of labor, they responded further by utilizing improved technologies in field and factory methods, and by the consolidation of small estates into larger production units. Nevertheless, progressive production increases were brought to a halt by full emancipation in 1838. By this time sugar and its associated products, rum and molasses, had already come to dominate Guyana's industrial structure. 


\section{Labor Supply}

An important dynamic of the industrial structure has been the labor supply. Through the movement of labor, plantation agriculture has profoundly affected the country's urban history. This sub-section focuses on the supply of African slave labor, which the plantation system necessitated.

As cultivation began to spread in the seventeenth century, the necessity for an adequate supply of labor became acute. The system of large-scale sugar cane production as introduced by the Dutch required a large, cheap, labor force. Initially the Dutch attempted to enslave the local Amerindian population, but these efforts were unsuccessful. Since they were well acquainted with the environment, it was not difficult for the Amerindians to escape into the interior ${ }^{86}$ furthermore, once captured, many succumbed to European diseases or resorted to suicide. Resistance of Amerindians in Guyana as elsewhere in the Caribbean took many forms, including the resettlement of rebel (maroon) communities. Furthermore, European settled laborers were difficult to attract. To fill the void, the DWIC, with its monopoly of the African slave trade, cast its attention to the African continent.

${ }^{86}$ Jeffrey and Baber 1986, op.cit., p. 10. 
Caribbean plantation society was based on a slave mode of production. This meant that production was organized by a class of property owners who owned not only the land and other means of production but slaves as well. Slavery was to become the linchpin of the economy. It was an economic response by the Europeans to solve the labor problem of plantation agriculture. Incorporated into the modern world system, Guyana and other Caribbean colonies became a theater where European capital and technology combined with African slave labor and Amerindian lands to produce a new form of economy based on the large-scale production of a staple commodity - sugar.

Beginning in the late seventeenth century and persisting with slight alterations into the early nineteenth century, the Guyanese economy was part of a state-sponsored and -controlled world economic system. In this Atlantic system, goods were carried from Europe to West Africa, there to be exchanged for slaves, who were in turn taken to the Caribbean as laborers. Europe was also the source of a variety of manufactured goods and food sold to Guyana.

The large-scale importation of African slaves, commencing in the 1660s, resulted in favorable profits being made in the country. The planter now had at his disposal the necessary labor to respond to all of the critical periods of the planting and harvesting seasons. For the next one hundred and seventy years Guyana was a slave 
plantation society, specializing in the export of tropical staples to Europe and North America.

The colony's economic growth was held in check for much of the period by a severe shortage of slaves. The labor power of African slaves was an essential component in early sugar plantation agriculture, and their scarcity was especially debilitating to the fledgling economy. The DWIC, with its monopoly on the slave trade, was unable to supply the requisite numbers of slaves on the plantations. Many planters, with tacit approval from governors such as Gravesande, resorted to smuggling slaves from the neighboring colonies. ${ }^{87}$

Integration into the embryonic world capitalist system had failed until emancipation to change the pre-capitalist outlook of the planters. Hitherto, productivity and efficiency had been met by the acquisition of more labor and more land. Investments in technological innovation were being retarded under a slave mode of production that gave little incentive for improvements in factory production. The planter class initially failed to grasp that sugar production is a manufacturing as well as an agricultural process. Once sugar cane is harvested, the juice must be extracted immediately and processed into sugar. But with the increasing cost of labor and the constraint on the labor supply after 1807, industry-wide technological developments

\footnotetext{
${ }^{87}$ Netscher 1888 , op. cit., p. 60 .
} 
became more pronounced. In 1814, triple-effect evaporating machines used for distilling cane juice began to replace inefficient fire-heated tayches. ${ }^{88}$ A more important innovation was the introduction of the vacuum pan in $1830 .{ }^{89}$ Guyana was the first British colony to adopt the vacuum pan. It permitted the extraction of more sugar per unit of juice and also provided a superior quality of sugar. Through this innovation, the now world-famous yellow Demerara crystals were produced.

By the 1830s the inadequacies of slavery as a mode of production had become self-evident across the Caribbean. since the abolition of the slave trade, production costs had grown appreciably. Planters were now compelled to be concerned with the reproduction of labor power to maintain their labor force.

Attention to reproduction involved increases in the level of subsistence and a resulting decline in the rate of exploitation. Furthermore, coercion and costs of supervision were relatively high and served to cut deeper into profits. The system was inherently unstable; however, not every planter immediately recognized the benefits of a free labor market in which laborers would compete for jobs and be responsible for their own subsistence. In Guyana, the plantocracy feared that once slaves were emancipated

\footnotetext{
${ }^{88}$ Williams 1950, op. cit., p. 11

${ }^{89}$ Webber 1931, op. cit., p. 158.
} 
they would leave the estates en masse and regress into a life of idleness and barbarity in the interior. They were convinced that former African slaves would work only under the whip. To be separated from the estates therefore would not only be economically disastrous for planters, but they argued in the racist dialogue of the day that it would also isolate Africans" from the "civilizing influences" of industry.

The institution of slavery officially came to an end in Guyana on August 1, 1834. Ex-slaves, however, were compelled to serve a period of "apprenticeship" before they were finally allowed to savor complete freedom. Field workers (praedials) were required to work for six years; and house and factory hands (non-praedials), whose hours of work were longer, were commanded to serve for four years. Compensation awarded to Guyanese planters totalled a little over 4,000,000 pounds sterling for the colony's 84,915 slaves or nearly 51 pounds per slave, less than one-half the price at which slaves were being sold in the 1820s.91

\section{Immigration}

Hoping to ameliorate the labor situation, the planters immediately sought to save their industry and to redress the

\footnotetext{
${ }^{90}$ That is, the descendants of slaves who were brought from Africa to labor on the plantations.

${ }^{91}$ Great Britain. Colonial office. 1949. Report of a Commission of Inquiry into the sugar Industry of British Guiana. London: H.M.S.O., p. 14 .
} 
imbalance in the country's black/white population composition by importing indentured laborers from Europe. During the apprenticeship period (1834-38), sporadic attempts were made at introducing immigrants from various corners of the globe, but these proved to be most disastrous (Table V). The majority died on their arrival in the country, and the remainder were forced to return to their countries of origin. ${ }^{92}$

In 1835, a concentrated effort was made to introduce Portuguese immigrants from Madeira, and although the 429 indentures who came were not a success, this source was to become an important supplier of labor at a later date. ${ }^{93}$ The general failure of European immigration led planters to scour the nearby West Indian islands. Between 1835 and $1838 ; 5,926$ indentured laborers were brought to Guyana, of which some 5,000 came from the West Indian islands of Antigua, Barbados, st. Kitts, Montserrat, and Nevis. The islands, however, could not meet the numbers demanded by the Guyanese planters, who were also meeting stiff opposition from island planters who were none too pleased to see their labor supplies decimated by their southern counterparts. Determined to secure an indentured, and therefore malleable, labor force, the Guyanese plantocracy cast its eyes towards the east and to India.

\footnotetext{
${ }^{92}$ Dalton 1855, op. cit., p. 448 .

${ }^{93}$ Webber 1931, op. cit., p. 177.
} 
TABLE V

GUYANESE IMMIGRATION 1835-1838

\begin{tabular}{|c|c|c|c|c|c|}
\hline Year & West Indies & Madeira & India & Africa & Total \\
\hline 1835 & 157 & 429 & & & 586 \\
\hline 1836 & 1,427 & & & & 1,427 \\
\hline 1837 & 2,150 & & & & 2,150 \\
\hline 1838 & 1,266 & {[} & $\underline{396}$ & 91 & 1,753 \\
\hline Total & 5,000 & 429 & 396 & 91 & 5,916 \\
\hline
\end{tabular}

Source: Webber 1931, p. XVI; Nath 1970, p. 219.

\section{DEMOGRAPHY}

Because there was little significant rural-urban migration during the period prior to emancipation, this section chiefly highlights the effects of fertility and mortality on Guyana's demographic composition. It provides population estimates for the fledgling urban settlements (Kijkoveral, Ft. Nassau, Stabroek/Georgetown, and New Amsterdam), and it assesses the repercussions of the abolition of the slave trade and slavery on the urban hierarchy.

Population estimates are extremely difficult to ascertain during the early colonial period. one conservative estimate places the Amerindian population in the 1660 s at about 50,000 and the slave population at $2,500 .{ }^{94}$ The European population was generally believed to be less than 100. Even amongst Caribbean slave societies,

${ }^{94}$ Webber 1931, op. cit., p. 16. 
such ratios (non-European/European) were unusually high. ${ }^{95}$ The population of Guyana during the slave plantation era was overwhelmingly rural. Settlements were little more than transshipment points oriented towards the metropole; and because of the tenuous nature of Dutch activity and the general lack of interest in the country, both Kijkoveral and Ft. Nassau were very small settlements.

Population increase in the settlements was remarkably slow. In the early 1680s, Kijkoveral is reported to have had forty soldiers and twelve slaves stationed there, besides the commander, the secretary, the clerk, and the predicant and his wife. Eleven years later, Commander Beekman reported to the Directors of the DWIC that at Kijkoveral and on the company's three plantations in Essequibo there were forty-eight Europeans, including soldiers, fourteen colored ${ }^{96}$ persons, and two hundred and twenty-three slaves. ${ }^{97}$

The liberalization of settlement requirements stimulated an upsurge in Essequibo's population during the 1700s, and this increase was reinforced by the opening of the Demerara region in 1746. The Berbice colony also experienced a mini boom, and in 1762 the official population

\footnotetext{
${ }^{95}$ More typically $13: 1$.

${ }^{96}$ For the most part descendants of African slaves and

${ }^{97}$ Rodway 1891, op. cit., pp. 43-48.
} white settlers. 
estimate returned a total of 4,423 persons, excluding free Amerindians. According to the count there were 346 Europeans, 244 Amerindian slaves, and 3,833 African slaves constituting the bulk of the population. As would be expected, most of the colony's inhabitants resided on the plantations. Ft. Nassau and the adjacent settlement of New Amsterdam accounted for only 150 African slaves, 10 Amerindian slaves, 30 European officials, and a handful of soldiers. ${ }^{98}$ However, in the following year Berbice was the scene of a great slave rebellion that brought over thirty years of planter prosperity to a shattering end. The uprising began at Plantation Magdalenburg on the Canje Creek; and when it was over a year later, the colony had been reduced to a shambles. The bureaucracy was completely destroyed, and many of the officials either were dead or had departed. The official returns for 1764 showed that the total population had declined by almost one-quarter to 3,486 persons. The slave population suffered the greatest losses, but the Europeans witnessed a more severe proportional decline in numbers; of the 346 whites in 1762 , only 116 remained. ${ }^{99}$

Stabroek, the capital of Essequibo and Demerara, in 1784 contained 88 houses and a total population of 780 inhabitants. Of these, there were 466 Africans - comprising

\footnotetext{
${ }^{98}$ Ibid. , pp. $172-173$.

${ }^{99}$ Clementi 1937 , op. cit., p. 75.
} 
the bulk of the population - 238 Europeans, and 76 persons of mixed ancestry. ${ }^{100}$ The return of slaves for Berbice, for the year 1790 was only 5,862 , a little over the pre-1763 level, but the numbers increased to 6,709 by 1792 and to 8,232 in 1795 . In the latter year the entire population of Berbice was estimated at 10,000 persons, whilst the total for Essequibo and Demerara was put at $60,000 .{ }^{101}$

Direct growth of the capitals of Essequibo/Demerara and Berbice was due almost exclusively to immigration (as opposed to internal migration or natural increase); this in turn was an indirect response to the importance of stabroek and New Amsterdam as places of security as well as administrative, commercial, and social centers. However, some inter-urban migration did occur as a result of the shift of the capitals from Ft. Nassau to New Amsterdam, and from Borsselen Island to Stabroek.

Fertility in the towns and in the countryside remained low and mortality high. Contemporary accounts clearly indicate that arduous living conditions killed many whites who came, encouraged some to leave, and discouraged other who might have come. Malaria, smallpox, yellow fever, dysentery, and other tropical diseases were common causes of

\footnotetext{
${ }^{100}$ Sancho, T.A. 1966. Highlights of Guyanese History. Georgetown, p. 15 . ${ }^{101}$ Clementi 1937, op. cit., p. 78.
} 
illness and death. For example, in 1792, smallpox was reported as "prevalent" in the colonies. 102

Those who survived illness often found it difficult or impossible to adapt to insects and the tropical climate. Although Africans were more accustomed to life in the tropics, the rigorous working conditions exacerbated the effects of the diseases peculiar to Guyana. The toll was tremendous. Some estimates claim that roughly one-twelfth of the plantation labor force was continuously incapacitated. ${ }^{103}$ Such was the mortality that the life expectancy of newly-arrived slaves was estimated at only 22.8 years. ${ }^{104}$

The natural decrease that typified the demography of Guyanese slaves can be attributed to a high level of mortality and a low level of fertility. Much of the mortality took place during the period of "seasoning" (one to three years) of newly imported slaves. In addition to those who died during passage, many who landed already suffered from one disease or another. Furthermore, slaves were immediately subjected to an extremely difficult life under alien conditions. Mistreatment came not only from

\footnotetext{
${ }^{102}$ Rodway 1893, op. cit., vol. II, p. 59 .

${ }^{103}$ Daly 1975, op. cit., p. 134 .

${ }^{104}$ Peek, P. and G. Standing. 1982. State Policies and
} Migration. Studies in Latin America and the Caribbean. London: Croom Helm, p. 256. 
white overseers, but sometimes from already-established slaves.

Malnutrition was common in some periods of drought and on certain plantations. Although slaves could and, indeed, were expected to grow their own food, some plantations supplied insufficient provision grounds for a very large labor force. Planters did not particularly encourage their slaves to reproduce, since they considered it more costly (in food and in time that might be taken off work by a pregnant or postpartum mother) to breed slaves than to import them. Reproduction was also hampered by the unbalanced sex ratios in the country. It was the custom for slave ships to transport two-thirds men and only one-third women. ${ }^{105}$ Also, mortality among children under the age of five was very high. Toward the end of the eighteenth century, after the abolition movement had gathered steam and especially after the slave trade ended in 1807, reproduction was encouraged, with limited success at first. In any event, the conditions of slave women seemed to have been such that childbearing was difficult. Hard labor in the fields, venereal disease, and a variety of illnesses and mistreatment all had negative effects on fertility. ${ }^{106}$

${ }^{105}$ Netscher 1888 , op. cit., p. 139. Much more recent work on slavery and statistics confirms that African societies increasingly favored exploiting female slave labor, preferring to export males.

${ }^{106} \mathrm{Nath}, \mathrm{D} .1970$. A History of Indians in British Guiana. London: The Author, pp. 2-3. 
Furthermore, some slave women, particularly creoles, were believed by Europeans to be unwilling to bear children since it made them unattractive to whites and therefore lost them privileges that accrued to those who had sexual relations with their masters. It is also likely that women controlled reproduction as a form of resistance. ,

With the British occupation in 1796, the colonies experienced an influx of population through the arrival of British West Indian planters and their slaves from the circum-Caribbean region. ${ }^{107}$ The colonies were returned briefly to the Batavian Republic following the signing of the Treaty of Amjens on March 25, 1807. Eleven years of British rule resulted in a twofold increase in the slave population in Berbice from 8,232 to 17,885 . A similar increase was noticeable in Demerara-Essequibo as slave importations increased in volume. ${ }^{108}$ The abolition of the slave trade in 1807 stemmed the flow, but slaves continued to be imported in limited numbers under certain restrictions and regulations. Given the disparity in the composition of the sexes, the slave population in Berbice had increased to 25,169 , a figure which, according to Rodway, was the highest ever registered in the colony. ${ }^{109}$ By 1812 , five years after

\footnotetext{
${ }^{107}$ Rodway 1893, op. cit., vol. II, p. 152 . ${ }^{108}$ Rodway 1893, op. cit., vol. I, p. 266. ${ }^{109}$ Ibid. , p. 273.
} 
the abolition of the slave trade, the Guyanese slave population amounted to $100,000.110$

The population of Georgetown ${ }^{111}$ in October 1819 was 10,519, including, 1,683 Europeans, 2,756 coloreds, and 6,080 slaves. ${ }^{112}$ A decade later the town's population amounted to 12,604 , viz., 1,620 Europeans, 4,368 coloreds, and 6,616 slaves. ${ }^{113}$ Whilst the increase in population was negligible, most of the expansion occurred within the colored population.

In 1831 , Georgetown, with a population of 12,604 accounted for 12.5 percent of the country's total population and over 78 percent of the urban population. Georgetown was four-and-a-half times the size of New Amsterdam, the only other urban center (Table VI).

TABLE VI

POPULATION DISTRIBUTION 1831

Year Guyana Georgetown $\%$ N/Amsterdam $\%$ Urban $\begin{array}{llllllll}1831 & 100,536 & 12,604 & 12.5 & 2,800 & 2.8 & 15,404 & 15.3\end{array}$ Sources: M.C.P 1832; B.B. 1832 .

${ }^{110}$ Webber 1931, op. cit., p. 134 .

"IITe name given to stabroek by the British in 1812 .

${ }^{112}$ Dalton 1855, op. cit., p. 337.

${ }^{113}$ Schomburgk 1840, op. cit., p. 24. 
Following the abolition of slavery and the Act of Apprenticeship on August 1, 1834, Dalton described the scene in Georgetown thus:

The town was like a hive swarming with inhabitants. From all parts of the country they flocked to the metropolis, and that movement so simple, so natural in itself, established a principle which was injurious to the more remote districts. ${ }^{114}$

For most, the move to Georgetown was but a brief sojourn. Although slavery had been abolished, each of the former slaves was required to serve a period of apprenticeship with his erstwhile employer. Many therefore returned from the urban areas to the plantations.

The number of slaves for whom compensation was paid in 1834 totalled 84,915 . This reflected a decline of 15,085 over the aforementioned 1812 population estimate. For the next 100 years augmentation of the country's demographic structure would be entirely dependent on immigration.

\section{INFRASTRUCTURE AND URBAN DEVELOPMENT}

The following section of this chapter sketches the development of the country's pre-emancipation capitals Georgetown and New Amsterdam in particular. It assesses the responses of planters and merchants in the distribution of infrastructural resources (roads, schools, hospitals, and water supply) over space; and it demonstrates how the

\footnotetext{
${ }^{114}$ Dalton 1855, op. cit., p. 397.
} 
domination of merchants and professionals in the combined Court during the first quarter of the nineteenth century spurred infrastructural activity in Georgetown. In addition, this section discusses the role of the pass laws and fire regulations in shaping urban areas during the period under review.

Economic and politico-social considerations have ultimately fashioned the settlement pattern in Guyana. Settlements which existed prior to complete slave emancipation in 1838 were created to serve the needs of a plantation economy. Of course, the earliest settlements were mainly those of the Amerindians, but these have not had much influence on the present pattern since Amerindians were compelled to survive the impact of European colonization by retreating further into the interior of the country. During the early Dutch period the emphasis was mostly on trade, and settlements were nothing more than trading depots. The first depot was built on the Pomeroon in 1580, but in 1596 the Dutch were driven out from the site by Spaniards and Indians. ${ }^{115}$

With the destruction of the Pomeroon settlement, settlers were forced to move further into the interior, and on an island at the confluence of the Essequibo, Mazaruni, and Cuyuni, they established Kijkoveral. A little later Ft.

\footnotetext{
${ }^{115}$ Ibid., p. 128 .
} 
Nassau, fifty-five miles up the Berbice river, was chosen to be the trading center of the Berbice colony.

Ft. Nassau was a rather small place in both area and population. The site was protected by a rectangular palisade ten feet high and by light artillery. ${ }^{116}$ within the palisade a church, a brick building utilized as a council house, and the governor's residence were erected. ${ }^{117}$ In time a village developed in the vicinity of the fort. It housed those who could find no room at the fort - lesser company officials and officers, carpenters, coopers, blacksmiths, etc. The village was given the name of $\mathrm{New}$ Amsterdam, and in 1733 it had gradually grown to include nearly thirty houses, a Lutheran church, and a clergyman's house. ${ }^{118}$ To facilitate the increase in construction activity, the DWIC built a brickery in 1722, and in 1734 it opened the Land's Welfare Inn to provide accommodation for new colonists. The inn also doubled as a coffeehouse and a club. ${ }^{119}$

Repeated sackings of the settlements by French and English naval expeditions in 1664,1689 , and 1708 clearly demonstrated that upriver locations were not immune from European incursions. Private settlers began to agitate for

\footnotetext{
${ }^{116}$ Netscher 1888 , op. cit., p.. 80 .

${ }^{117}$ Dalton 1855, op. cit., pp. 138-139.

${ }^{118}$ Bronkhurst 1890 , op. cit., p. 47 .

${ }^{119}$ Netscher 1888 , op. cit., p. 81 .
} 
a new center of administration in the Essequibo colony. The DWIC also recognized that Kijkoveral was much too inadequate to accommodate the increasing number of company functionaries. In 1716 the company granted permission to build a colony house at cartabo Point in the vicinity of Kijkoveral. The structure was completed in 1718, and Essequibo's administration was effected from there, whilst Kijkoveral ostensibly became an exclusive military garrison. The commander of the Essequibo colony was emboldened to make the move to Cartabo Point as a result of events in Europe. Most notably, trepidation of enemy attacks had declined appreciably following the Treaty of Utrecht in 1713. Moreover, internally it was discovered that the soil around Kijkoveral had been deteriorating and was nearly exhausted. Rodway presents figures for the fall in sugar cane output for a typical plantation at the time (Table VII) ${ }^{120}$

\section{TABLE VII}

DECLINE IN SUGAR-YIELDS ON INTERIOR LANDS

$\begin{array}{lr} & \text { Yields Per Acre (Pounds) } \\ \text { 1st crop } & 3,000 \\ \text { 2nd crop } & 2,000 \\ \text { 3rd crop } & 1,500 \\ \text { 4th crop } & 1,000 \\ \text { 5th crop } & 800 \\ \text { Source: Rodway 1891, p. } 67 . & \end{array}$

${ }^{120}$ Rodway 1891, op. cit., vol. I, p. 67. 
The decline in yields did not go unnoticed by the DWIC, and in 1721 Commander Laurens de Heere laid out a new company plantation at the mouth of the Bonaisca Creek. ${ }^{121}$ The plantation was given the name "Pelgrim", and it was the first significant plantation approaching the Guyanese littoral.

The settlers remained uncomfortable with the new arrangements. Migration to the coast was in its infancy, and colonists were demanding greater downstream protection. Since the new colony house was still a good way upriver they petitioned the states-General for a new downriver fort and capital. The company relented, and in 1739 the seat of government was transferred from Kijkoveral to Flag Island near the mouth of the Essequibo River. Situated near the mouth of the Essequibo River, Flag Island, later renamed Fort Island, presented the administration with some badly needed space for the erection of buildings and the cultivation of provision plots for company personnel. ${ }^{122} \mathrm{~A}$ few years later, a fort, Zeelandia, was erected on the island. ${ }^{123}$

The transfer of the seat of government from Cartabo Point to Flag Island confirmed that commitment to coastal development was inescapable. Furthermore, it was a shift

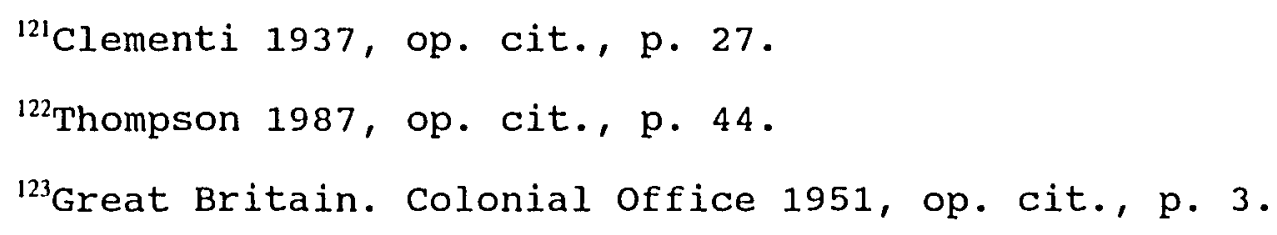


which confirmed the virtual cessation of interior trade with the Indians.

The private planters in Berbice also began to make demands for a fort to be constructed at the mouth of the Berbice River, and shortly after Zeelandia was built in Essequibo, permission was received to erect Ft. St. Andries. Unfortunately for Berbicians, the fort was of inferior quality, barely affording the residents a minimum of protection.

Settlement activity greatly accelerated after the colony was thrown open to settlers. The pace became frenetíc after 1746, when the Demerara region was openea and plantations were established along that river. As plantations began to spread towards the coastal reaches, a brandwagt (guardhouse) was erected in 1748 at the mouth of the Demerara River; to prevent smuggling and to give warning of impending attacks. Many English settlers had found their way to Demerara and by this time the region was clearly outstripping Essequibo. By 1753, Demerara had become a colony in its own right, and its administrative headquarters was to be found on Borsselen Island, the middle of three small islands, some twenty miles up the Demerara River. ${ }^{124}$ Borsselen was the preferred location, partly on account of its convenience to the commander's plantation and partly

\footnotetext{
${ }^{124}$ Rodway 1920, op. cit., p. 7.
} 
because there was a general consensus that the brandwagt was too far down the river.

In 1755, Borsselen Island, some seventeen miles up river was selected as the site and the capital of the embryonic Demerara colony. ${ }^{125}$ Borsselen's location was far from ideal, and Webber has suggested that the choice of the site was influenced by its proximity to the plantation of Jonathan Gravesande, son of the governor, Laurens Storm van's Gravesande. ${ }^{126}$

In 1759, a survey of what is now Georgetown was undertaken by Laurens Lodewijk Bercheyck, indicating how the land was divided and to whom it was leased. ${ }^{127}$ The layout of the plantations followed the typical Guyanese plan, which was influenced by their siting on the heavy clay soil between the river or sea frontage and the "pegasse" land which was located roughly ten miles inland. The plantations formed long parallelograms dissected by dams and drainage canals running from east to west. A series of sluices or "kokers" were built to keep out the waters of the river and sea at high tide and to allow the internal accumulated water to discharge at low tide.

The planned city of Georgetown is basically an extension of the above plantations. The plantation drainage

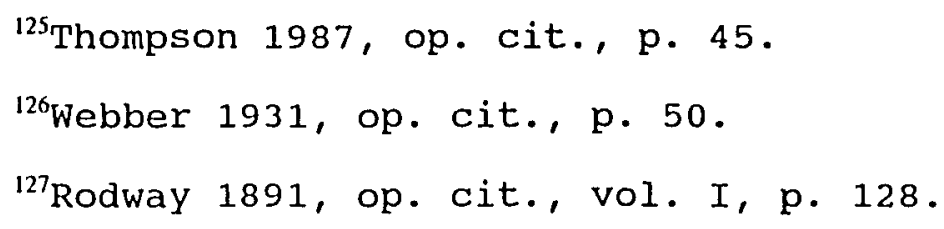


systems were retained, and the dams were converted into roads and streets when the town was first proclaimed in the 1780s. The "damstreets" were complemented by a number of intermediary parallel streets and cross streets running parallel to the Demerara River. The result was a gridiron network of straight thoroughfares which intersected at right angles.

The gridiron of straight and wide thoroughfares, and the system of rectangular blocks interspersed by canals, was directly associated with Dutch town-planning. Given the fact that the land was flat with virtually no relief, the gridiron layout was a logical choice. However, the gridiron pattern of the town was not of a uniform nature. In general, the Dutch were of the opinion that there was ample land to be had, and this attitude gave rise to a spacious and well-laid-out town. In some areas the canals, streets, and grass embankments were more than 100 feet wide from one property line to another. But since the plantations on which the town was. built were of varying widths, this variation resulted in dissimilar block and lot sizes in several parts of the town. The original size of lots in the town was 100 feet by 200 ; but in time, as subdivisions occurred, the lot sizes decreased and lots of just over 60 feet in width became the more common practice.

Despite the coastal migration of settlement and the corresponding concentration of population in the mid- 
eighteenth century, there was still a complete lack of roads in the country. The only means of travelling was by tentboats, rowed by Amerindians or African slaves. ${ }^{128}$ Since communication was chiefly by water and all commerce conducted with Holland, the inhabitants did not pressure the DWIC to construct road networks. Administration for Essequibo and Demerara were centered on two small islands Flag Island and Borsselen. The fact that both these colonies were administered from places not requiring roads only served to compound the absence of this particular form of infrastructural development. The importance of overland networks, however, was brought to the fore during the Berbice slave rebellion in 1763. The absence of adequate routes rendered it virtually impossible to quickly pursue slaves who had escaped into the bush. Essequibo and Demerara found themselves powerless and unable to lend support to the Berbice planters.

Following the 1763 rebelition, most of the colony's plantations were destroyed, and recovery was to prove a long and tortuous process. Ft. Nassau and New Amsterdam did not escape the onslaught, and though the settlement was partially restored, it never fully recovered after the insurrection.

The misfortune that befell Berbice did not appear to deter the developments being made in Essequibo and Demerara

\footnotetext{
${ }^{128}$ Webber 1931, op. cit., pp. 226-227.
} 
in particular. Ft. Kijkoveral was torn down in $1764,{ }^{129}$ its location no longer warranting a military garrison. In Demerara, questions were also being raised as to the suitability of Borsselen Island. The commanders favored the site since it was close to their plantations, but the planters argued that the site was much too inconvenient. They pointed out that all ships in the colony were required to use Borsselen as their port of entry and disembarkation, but that because of the river's shallow depth and swift current at this point, it was a difficult and time-consuming operation. Furthermore, they argued that since the colony was in an expansionary period it was bound to require more government buildings and establishments, and that these could not possibly be accommodated on the island. ${ }^{130}$ The company was unconvinced, and the commanders continued to refuse to relocate the capital.

In 1775 , the private planters lobbied for and were granted new lands in Demerara. Canals Nos. 1, 2, and 3 were dug specifically to enable private planters to acquire more land on the fertile coast. Two years later, with the canals nearing completion, the governor, van Schuylenburg, turned his attention to the development of public roads. He ordered the planters to make up a roadway, across the front of their estates, on which every person should have a right-

\footnotetext{
${ }^{129}$ Bronkhurst 1890 , op. cit., p. 42 .

${ }^{130}$ Netscher 1888 , op. cit., p. 63.
} 
of-way. The planters who had eagerly supported construction of the canals adamantly resisted van Schuylenburg's scheme. ${ }^{131}$ In contrast to the canals, they perceived little benefit to themselves from having roads across their land. After all, their trading links were primarily overseas. Development of the colony was of no interest to them. As long as their enterprises did not suffer, they had no incentive to invest in costly infrastructure. In any case, many plantation owners at this time were absentees who were not concerned with the overall economic health of the colony. This meant that the colony's social and political leadership was largely absent. No educational facilities were developed, as the wealthy preferred to send their children to Europe for schooling. There is some evidence that a school of sorts was established in Essequibo in 1685.132 However, the first undisputed evidence of a school in Guyana was not until 1800, when Elizabeth Goddard opened a coeducational boarding school in Stabroek. ${ }^{133}$

In 1781 , the Dutch had surrendered the colony to the British. Berbice, which had slowly began to recover after

${ }^{131}$ Rodway 1891, op. cit., vol. I, p. 25.

${ }^{132}$ The school simply provide religious rather than formal education for children of settlers. See, Bacchus, M.K. 1980. Education for Development or Underdevelopment?: Guyana's Educational system and its Implications for the Third World. Waterloo, Ont.: Wilfrid Laurier University Press, p. 7.

${ }^{133}$ Thomas, C.X. 1984. The Rise of the Authoritarian state in Peripheral Societies. New York: Monthly Review Press, p. 75 . 
the 1763 rebellion, was also captured by the British in the same year. Ft. St. Andries, a flimsy structure at the mouth of the Berbice River, was razed to the ground, and Ft. Nassau was unable to resist the attack. It was at this time that a proposal to move Ft. Nassau to the mouth of the river and build a new town was first broached. Meanwhile in Demerara, Lieutenant Colonel Robert Kingston, the British Lieutenant Governor, was persuaded to remove the seat of government from Borsselen to an area adjacent to the Brandwagt at the mouth of the Demerara River. ${ }^{134}$ Plans were progressing when the colony was surrendered to a French naval squadron on January 31,1782 . The absence of a recognizable urban center made a great impression on the French commander, the compte de Kersaint. He bemoaned the lack of a town, and in a proclamation issued on February 22, 1782, he declared:

This is perhaps the only instance of a European colony, among thousands throughout the world, which has arrived at some magnificence without the establishment of either a town or village. ${ }^{135}$

Kersaint argued:

That it is considered necessary to establish a capital, which would become a business centre; where religion would have a temple, justice a palace, war its arsenals, commerce its counting

${ }^{134}$ Guyana Heritage Society. 1986. A Guided Tour of Historic Georgetown. Georgetown, p. 1 .

${ }^{135}$ Clementi 1937 , op. cit., p. 42 . 
houses and industry its factories; where also the inhabitants might enjoy the advantages of social intercourse. ${ }^{136}$

In response to this glaring societal deficit, Kersaint proceeded to establish a town on the site of the Brandwagt, on the east bank of the river. A fort, Le Dauphin, was also built on the site; and on the west bank of the river a smaller fort, La Reine, was erected to provide protection for the town's projected inhabitants. ${ }^{137}$

As an inducement to urban development, the French issued grants of land in the town at an extremely attractive price. Lots were to be had at an annual tax of five stivers per half a square rood providing the recipient built a house within six months of the grant. ${ }^{138}$ slaves requisitioned from a less-than-enthusiastic plantocracy were ordered to dig two canals. The canals were unimaginatively named the North and South Canals, and between them was essentially the town - a dam with two rows of houses on either side, retaining the canals as their rear setbacks. Boats were still the preferred mode of transportation, and it was expected that the canals would be utilized to move goods and merchandise to the store-rooms located at the back of each house. The new town was called Longchamps, and sometimes La Nouvelle ville by the French. It was less than a mile long,

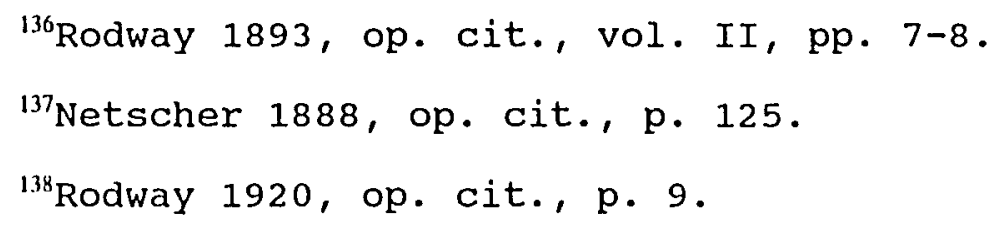


with several of its lots reserved for government buildings. The annual tax on house lots was expected to be applied to the maintenance and improvement of the embryonic town. The transfer of the seat of government from Borsselen was completed, and the new town became the administrative headquarters for the colonies. The centralization of administration gave Demerara and Longchamps/La Nouvelle Ville a clear advantage over their competitors. In January 1783, a post office, the first in Guyana, was established in the capital, enforcing the settlement's unique role as a provider of urban-type services. ${ }^{139}$

The colonies were restored to the Dutch in March 1784, and by a resolution of the home government on september 14 , 1784, the town was named stabroek after the president of the DWIC, Nicholas Geelvink, Lord of Castricum, Backum, and Stabroek. ${ }^{140}$ The Dutch on their return were astonished to find that an urban community of some note had developed in their absence.

There is some evidence that the French also made plans to relocate Ft. Nassau, the capital of the Berbice colony. However, it was not until 1785 that the final decision was made to abandon Ft. Nassau and to move the capital to a site at the confluence of the Berbice River and the canje

\footnotetext{
${ }^{139}$ Rodway 1893, op. cit., vol. II, p. 20 .

${ }^{140}$ Rodway 1920 , op. cit., p. 10 .
} 
Creek. ${ }^{141}$ The site selected appears to have been in the neighborhood of the former Ft. St. Andries. The future town was expected to provide the colony with a port that would maintain a vital maritime link with the metropole, as well as perform the role of an administrative center for Berbice. Construction of the new capital, named New Amsterdam after its counterpart upstream which had been in decline since 1763 and was now virtually abandoned, did not commence in earnest until 1790. The transfer of the capitals breathed new life into the colonies. Prosperity in the colonies was at the highest point it ever reached under the Dutch, and both stabroek and New Amsterdam were benefiting as a result.

A number of laws and controls were promulgated to influence the urban form and image of the towns. As early as September 1781, the Court of Policy passed a law that all kitchens in stabroek should be made of brick, to prevent the spread of fire. ${ }^{142}$ Four years later the court decided that no buildings roofed with troolies ${ }^{143}$ or thatch could be erected at stabroek and that property owners in the town would be required to supply slaves to cut grass and clean the trenches and dams. ${ }^{144}$

\footnotetext{
${ }^{141}$ Netscher 1888, op. cit., p. 125.

${ }^{142}$ Rodway 1893, op. cit., vol. II, p. 11.

${ }^{143}$ Leaves from the troolie palm.

${ }^{144}$ Ibid. , pp. 44-45.
} 
The physiognomy of the town was Dutch colonial in character. All of the buildings were constructed of timber, which was well suited to the low bearing capacity of the soil. The construction in all of the wards followed a similar pattern, that is, rows of houses were built with large gardens or yards on rectangular lots of land, with wide intervening streets and canals. As the town grew and the wards began to encroach on one another, they were able to become amalgamated into a coherent network as though the entire town had been planned at the same time.

The town was structurally unpretentious, though the wooden buildings gave Georgetown a distinctive character. Houses were raised from the ground by stilts, to prevent flooding; they possessed steep roofs, wide eaves, verandas which often extended the full width of the buildings to catch the northeasterlies, accentuated roof overhangs, and open staircases in the fronts and sometimes the sides of the houses. Many were adorned with carved decorations, small checked windows, Demerara shutters, and towers.

The Dutch influence and the general appearance of Stabroek were captured by Pinckard. On his arrival in the town in April 1796, he stated:

I could have fancied myself in Holland. The land appeared as one wide flat, intersected with dykes and canals; the roads mere banks of mud and clay, thrown from the ditches at their sides; and the houses bedaubed with tawdry colours, like Dutch toys, giving the whole a striking resemblance to the Mother country. The town is simply two long rows of houses, built very distant from each other, 
with a wide green in the middle, by way of street. It is more than a mile in length, running in a line from the river back to the forest - the most inconvenient form that could have been contrived, as it places most of the buildings far away from the river, and deprives them of the great advantages, for trade, which they might have had by being erected parallel with the course of the water. To remedy this defect canals and ditches have been cut, at the backs of the houses, which are perhaps the worst neighbours the inhabitants could have near them, for, being the receptacles of mud, and all the filthy drainings of the town, and only partially emptied by the reflux of the tide, they become highly offensive, and tend to generate disease. The causeway of bricks is continued throughout the whole length of the street; but the carriage road is mere clay and mud. ${ }^{145}$

The Dutch spent time building canals to enable colonial exploitation of the country. They were not committed to road building, although attempts were made to persuade planters to build and maintain a portion of the public road that traversed the coastal edges of their plantations. The British, upon their arrival in 1796, recognized the need to improve and expand the existing transportation network. Immediately after taking possession of Demerara and Essequibo, they were forced to send troops by sea to capture Berbice. This inconvenient and timeconsuming mode of transporting troops was grudgingly adopted, owing to the impassability of the coastal road. ${ }^{146}$ Having captured the colonies, the British conceived plans to establish a proper road linking together the coastal

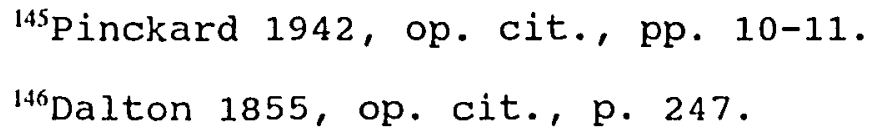


plantations. The main purpose of the road was not to transport agricultural commodities or to facilitate commerce, but, to enable troops to move quickly to stifle rebellions and attacks. As a result, the focus was on coastal communications whilst the hinterland was completely ignored.

The colonies continued to flourish in the wake of the British capture, and this was reflected in the urban expansion of stabroek. The upsurge in commercial activities and trade resulted in several important mercantile firms being established in stabroek. The town was extended along the river incorporating a number of plantations as it began to spread outward. A number of "towns" began to evolve in the vicinity of stabroek as the demand for housing, wharves, and businesses increased. Cummingsburg, Robb's Town, New Town, Werk-en-Rust, and kingston all owed their existence to the British conquest of 1796 .

Cummingsburg, to the north of stabroek, began life as a warehouse and business district catering to the overseas trade dominated by British merchants. The town also boasted a residential district, almost two miles in circumference, which was neatly laid out into large and convenient lots. ${ }^{147}$ Robb's Town, initially known as Albinus or Bridgetown, was primarily the residence of free coloreds and former

${ }^{147}$ Bol ingbroke, H. 1941. A Voyage to Demerary, 1799-1806. Ed. V. Roth. Georgetown: Daily Chronicle, p. 54 . 
slaves from Barbados. A good number of hucksters who plied their trade in the colonies also lived here. Located north of stabroek, the town was a ramshackle of slums and shanties. ${ }^{148}$

New Town, also to the north of stabroek, functioned as a bustling retail business center. Businesses ranging from goldsmiths to "slop-sellers" could be found here, and almost every item desired could be purchased on one of its four principal streets. ${ }^{149}$

The town of Kingston, built by the British army to house its officers, soon became the residence of Guyana's elite. Professionals, wealthy merchants, and planters were drawn to this northern coastal location to take advantage of the site's refreshing trade winds. Situated at the mouth of the Demerara and directly on the coast, the town had a salubrious reputation that was not entirely unwarranted. Houses here were in direct contrast to those in Robb's Town. They were large and well-built on solid brick foundations, each having its own garden. ${ }^{150}$

Werk-en-Rust was the only town south of stabroek. The former plantation was mainly the residence of timber merchants and those who traded with the North American continent. In 1799, Werk-en-Rust became the first of these

\footnotetext{
${ }^{148}$ Ibid., p. 56.

${ }^{149}$ Ibid. , pp. 56-57.

${ }^{150}$ Ibid. , p. 54 .
} 
small "towns" to be incorporated into stabroek. ${ }^{15 t}$ Indeed, expansion of the "towns" was proceeding at such a rate that Bolingbroke, an English merchant, could scarcely comprehend the dizzying pace:

New buildings are erecting every day, and I am really at a loss to know where the inhabitants come from to fill them; as most planters reside on their estates. ${ }^{152}$

Warehouses, quays, careenage yards and other repair and maintenance facilities for ships, fortifications, churches, taverns, gaming-houses, and cook-houses all contributed to the bustling port.

In a short time the price of land had advanced so much that those with meager resources were compelled to purchase lands at a considerable distance from stabroek, where lower prices prevailed. Additional testimony to the expansion of towns in the colonies can be seen in the growth of New Amsterdam. In 1785, having supplanted its upriver namesake, the construction of the town was initiated; but progress at the onset was painfully slow. When Pinckard visited the town in 1796, it was still a fledgling settlement. He reported:

The town is yet in embryo. According to a plan... for its construction it is to be built upon the angle, or peninsula, between the rivers berbische and kannye, extending along the bank of the former. The land on which it is to be erected is in part cleared of its wood, and divided into

${ }^{151}$ Rodway 1920, op. cit., p. 16.

${ }^{152}$ Bol ingbroke 1941, op. cit., p. 56. 
lots ready for building, but, at present, only here and there a scattered house is to be seen. Beyond the prepared land, and not half a mile from the government-house, the bush still overhangs the river kannye; but those destructive engines, fire and the axe are now directed against it. ${ }^{153}$

Despite its early stage of development, Pinckard was captivated with the government-house, which he described as "beyond comparison" and the "handsomest" and most "spacious edifice" he had ever seen in South America. But, when Bolingbroke laid eyes on the town a few years later, in 1802, he was greatly impressed by the well-laid-out town and the fact that New Amsterdam possessed two taverns whilst none could be found in stabroek. ${ }^{154}$ The layout reflected a conscious attempt to foster health and convenience:

Each allotment appears an island within itself; the ditches, round the houses, fill and empty themselves every tide, by which means all the filth and dirt is carried off before it has time to stagnate, or occasion unhealthy sensations. Each lot is a quarter of an acre of land, separated as before mentioned from the adjoining one; which not only leaves a free circulation of air, but allows to every house a kitchen garden, which produces vegetables sufficient for the family. The houses are different from those of stabroek, in this respect, they are not more than a storey and a half high, very long and narrow, with galleries on either side for the purpose of walking and smoking in the shade; they are mostly covered with troolie and plantain leaves, a species of thatch in preference to shingles, as being considered much cooler; but the quantity of vermin and insects which they harbour, does away every other consideration with English men, whose houses in New Amsterdam may be distinguished by being

${ }^{153}$ Pinckard 1942, op. cit., p. 74.

${ }^{154}$ Ibid. , pp. 111-112 . 
shingled. ${ }^{155}$

Planters in Berbice were incensed by the fact that on May 17, 1803, the Court of Policy resolved to clear the forest behind stabroek and to light a street in the town at night. ${ }^{156}$ However, it should be made clear that most of the improvements taking place in stabroek at this time were met by assessments on the value of buildings and lots in the town. For instance, in July 1805, the residents of stabroek were charged a three percent special assessment to pay for improvements on the La Penitence Road and the middle dam. ${ }^{157}$ In July, Camp street, a major thoroughfare in stabroek, was laid. The improved roads were a great advantage to trade and commercial activity. st. clair, a soldier of the occupying British army, in 1806, commented on the improvements of the once treacherous roads in stabroek:

The roads and streets throughout the town are covered with bricks, which becomes consolidated and makes a dry pathway even in rainy weather. ${ }^{158}$

In April 1806, the coastal road planned by the British in 1796 was completed. The road facilitated the interplantation movement of goods and people, although this was not quite the rationale behind its construction. The new highway stretched from Demerara to Berbice, and though it

\footnotetext{
${ }^{155}$ Bolingbroke 1941, op. cit., p. 111.

${ }^{156}$ M.C.P., 1803 .

${ }^{157}$ M.C.P., 1805 .

${ }^{158}$ St. Clair 1947, op. cit., p. 12.
} 
remained impassable in the rainy seasons, it was instrumental in creating a ribbon-like settlement network from what had been independent plantations exclusively oriented towards the metropole.

British influence was pervasive, and in a move to stamp their identity on the country, they renamed the town called stabroek as Georgetown, after the reigning British monarch, King George III, on May 5, 1812.159 Georgetown at this time encompassed an area extending from Kingston in the north to Albouystown in the south, and the tract eastward from the Demerara River to Camp street. Several of the small "towns" such as Cummingsburg, Robb's Town, New Town, Kingston, and Werk-en-Rust, therefore, became wards (districts) in the newly named town.

Within Georgetown, the wards of New Town, Robb's Town, and Werk-en-Rust were perhaps in the most deplorable condition. They were covered with shanties belonging to the poorer classes, between which ran dangerous and cramped alleys. The lack of fresh water was a persistent problem to all who lived in Georgetown, but for the poorer folks the situation was much worse. Without vats or cisterns, they suffered much privation during the dry season. Fortunately, in 1825 the Lamaha Canal project was launched to bring water to the town's population. ${ }^{160}$

\footnotetext{
${ }^{159}$ Webber 1931, op. cit., p. 134.

${ }^{160}$ Gazette, Nov. 3, 1825.
} 
The ascension of merchants and professionals to the Combined Court stimulated a number of public works in Georgetown. In 1825 the stone work for a sea dam was commenced to resist coastal erosion of the northern part of the town. The same year saw the commencement of the construction of the Lamaha Canal, bringing fresh water from the Lamaha creek a distance of about fifteen miles for the supply of the population of Georgetown. ${ }^{161}$ A mere nineteen years earlier, st. clair had remarked:

As no springs are to be met with, except in the interior of the country...each house is provided with vats or cisterns and pipes to conduct the rain-water from the roof, but, as this supply is inadequate to the wants of families during the dry season, they are obliged to send, at an enormous expense, a considerable distance up the country for clear water: but this is so strongly impregnated with vegetable matter as to be of a yellowish tint, and it is very pernicious to the stomach which is unaccustomed to it. ${ }^{162}$

Fire regulations were bolstered in 1803 with the establishment of a fire service. Two engines were placed in the northern and southern sections of the town, and every householder was requested to provide two leather buckets to assist fire fighters. The regulations were far from adequate, and in 1828 two disastrous fires occurred which levelled parts of Charlestown and almost completely destroyed New Town. The whole of New I'own, from Water street to High street and croal street to South Street, was

$$
\begin{aligned}
& { }^{161} \text { Blue BooK (B.B), } 1828 . \\
& { }^{162} \text { St. Clair 1947, op. cit., p. } 13 .
\end{aligned}
$$


razed to the ground, the fire destroying goods and property worth over $1,000,000$ dollars. ${ }^{163}$

As a result of the 1828 fires, Charlestown and New Town were rebuilt afresh; roads and lots were laid out and several improvements made. An ordinance was passed to prevent the future development of crowded shanties, and this ordinance was reinforced in 1838 by the "Consolidated Ordinance for the Better Regulation of Georgetown."164 The law contained rules regarding the construction of buildings, stellings, and other structures in the capital. These fires, and in later years other like it, necessitated rebuilding and thereby indirectly stimulated urban planning in Guyana.

In 1828, the main road through Georgetown was extended two-and-a-half miles, at a cost of four hundred pounds, with ballast ${ }^{165}$ bought from incoming ships, and stone brought from one hundred miles up the Essequibo River. ${ }^{160}$ Africans were being hired and charged with weeding and repairing the roads, and cleaning the trenches in the town. The government also now began to contribute to a special Georgetown fund mandated to maintain the general appearance and welfare of the town. Aid donated amounted to over 400

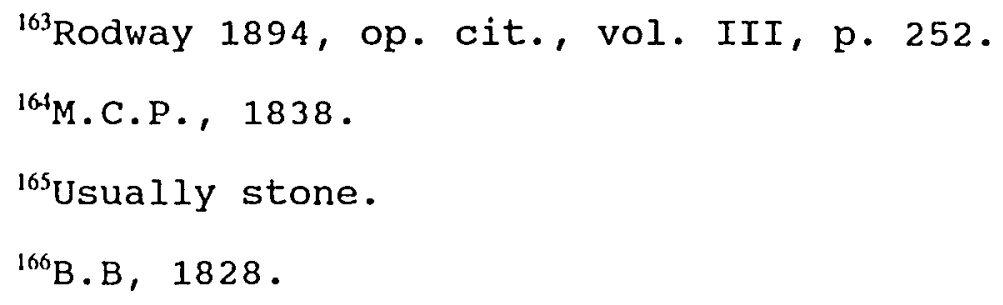


pounds in 1828.167 Georgetown, by gaining a degree of service not available elsewhere, was beginning to be set apart from surrounding areas, resulting in increasing differentiation between town and country.

A scouring of the minutes of the Combined court and the Blue Books from 1812 to 1831 clearly reveals that members of the court determined levels of taxation as well as expenditure of funds, including those earmarked for Georgetown. The estimated expenditure for Georgetown in 1831 included some of the following: hire of laborers 30,000 pounds, lighting of town's lamps - 8,400 pounds, stone ballast for streets - 18,000 pounds, medical attendance - 880 pounds, etc. Some of the expenses were to be met by a tax of two percent on the 980 lots and buildings in the town, amounting to 6,259 pounds. Another paltry amount was expected from market fees and rental of stalls. ${ }^{168}$ In the same year the entire Amerindian population of the country were allocated, 66 pieces of salenpores, $600 \mathrm{fish}$ hooks, 7 tinder boxes, 24 looking glasses, 6 hoes, 100 needles, 24 knives, and 24 combs! ${ }^{169}$ Within Georgetown, members of the colored group as a rule resided in the poorer wards of the town, and as a result the growth of shanties became more intense in these

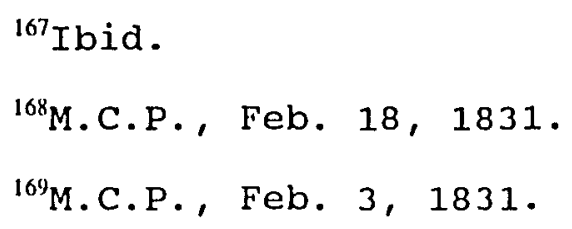


districts. Sanitary arrangements were most inadequate throughout Georgetown, but in the poorer wards the situation was virtually intolerable. All refuse was dumped into the canals, which soon became stagnant, posing a health hazard to those who lived near them and to the slaves who were compelled to clean them from time to time.

New Amsterdam provided a stark contrast to the squalid conditions in the poorer sections of Georgetown. The town's population had yet to reach 3,000 , but according to Dalton:

About this period [1830s], the town had resumed an air of prosperity and rising importance; there were several fine buildings, the old court-house especially, which together with the lively and clean private houses, prettily surrounded by lovely tropical fruit-trees and shrubs, presented an aspect of striking beauty to the visitor. ${ }^{170}$

On July 21, 1831, Berbice, Demerara and Essequibo were merged to form the united colony of British Guiana. ${ }^{171} \mathrm{~A}$ capital and a port were required to provide administrative, trade, commercial, and service functions. since Georgetown with its developed infrastructure had already been supplying these functions, it was selected over New Amsterdam, and from this date the importance and consolidated growth of the town was assured. The effect of the decision was to relegate New Amsterdam even further in Guyana's immature urban hierarchy. With no intermediate towns, Georgetown had begun to dominate the two-tiered urban network.

\footnotetext{
${ }^{170}$ Dalton 1855, op. cit., pp. 378-379.

${ }^{171}$ M.C.P., Aug. 3, 1831.
} 
Under slave plantation society, urban development was restricted and towns small. The vast majority (85 percent) of the population were residing on estates or in plantation villages. The society was defined by forced confinement of slaves on the plantations and forms of development which were centered around sugar. Few possibilities were available for wholesale migration to towns or for the creation of significant urban employment, as was the case with European industrialization. Guyanese society was to remain agrarian, and town life was to remain constricted for Africans during this period. This was especially so since, under "normal" conaitions, towns tend to increase interaction and communication; and this could have permitted a good deal of association between races in a color-based socioeconomic system in which fear of the socially dominant class was an important component. Therefore, there was every reason to have slaves confined on the plantations and in rural areas. Those of the plantocracy clearly desired such a situation; but in a society dependent on the labor power of slaves, workers were also required in Georgetown and New Amsterdam as perquisites to accumulating power and affluence.

Population increases in Georgetown and New Amsterdam resulted primarily from two streams of migration immigration from Europe, Africa, and the West Indies and the in-migration of both whites and non-whites from sugar 
plantations. The latter movement was only partly influenced by the demands of these towns' economies and the desires of the rural population. For while free whites were able to live anywhere, slaves and indentured servants were confined to sugar estates unless their owners resided in the two towns or gave them permission to move there. Conversely, the free colored population and free Africans were encouraged to live in Georgetown and New Amsterdam. And since it was believed that they would incite the slaves to rebellion, they were largely denied employment on the plantations.

The nobility, and hence the migratory tendencies, of slaves was drastically curtailed by law; even a slave who visited the sunday market in stabroek was obliged to carry a pass signed by a white person. Although this legislation was seldom enforced, it unquestionably restricted movement to Georgetown and New Amsterdam, and transformed the estates into more easily controlled social cells. Nonetheless, the only sizeable group of mobile slaves, the runaways, frequently sought anonymity in Georgetown, specifically in the poorer wards, where the regimentation of plantation life was supplanted by a more confused liberal order. Some runaways even ventured to establish a settlement behind Peter's Hall, just a few miles from Georgetown, from which they were able to launch raids on nearby plantations. ${ }^{172}$

\footnotetext{
${ }^{172}$ Rodway 1920, op. cit., p. 51.
} 
The final days of slavery was marked by the incorporation of Georgetown in 1837. Superintendence of the town was placed under a mayor and town council. Eleven councilors were appointed, corresponding to the eleven wards into which the town was divided, namely Kingston, $\mathrm{N}$. Cumingsburg West Ward, N. Cumingsburg East Ward, Robb's Town, Columbia and Lacy Town, New Town, Stabroek, Werk-enRust, and Charles Town.

\section{Land Use}

This sub-section describes land use during the period and highlights the dominance of plantation agriculture over the space economy. It details the search for fertile agricultural lands and the importance of the ecology in determining settlement.

During the early colonial era plantations clung tenaciously to the higher reaches of the rivers. All were located on the banks of the rivers, between thirty and fifty-five miles from their mouths. In Berbice, most plantations were located around Fort Nassau. Similarly, in Essequibo, most plantations were in the vicinity of Kijkoveral. Up river locations were preferred to the coastal locations for cultivation and settlement, because they offered some degree of protection from enemy incursions and marauding pirates who regularly terrorized the "Wild Coast" (i.e., the area between the orinoco and the Amazon). Unlike the low-lying swampy coastal areas, the upriver 
locations were well drained, easily worked, and above high

tide; and they were considered to be much more salubrious. ${ }^{173}$

Movement to the coast was fuelled in 1729 with the opening up of Essequibo to settlers from other countries besides Holland - in rapid time, West Indian planters were flocking to Guyana to take possession of land being given free of charge with exemption from taxes for ten years. Settlers were allowed to bring their own slaves, and each settler was granted a fixed amount of land. Land was set at 1,000 acres for the cultivation of sugar and at 500 acres for other crops. By 1745, all the available first-depth land, suitable for crop production in Essequibo, had been allocated to colonists. Even the islands at the mouth of the Essequibo and on the banks of the Iturbisi and Supenaam Creeks were allowed to be settled by the wave of new colonizers. ${ }^{174}$

Berbice also benefitted from the developments taking place in Essequibo. Between 1733 and 1735, a total of fifty-eight land grants amounting to 42,300 acres were allotted. ${ }^{175}$ In the latter year the DWIC operated twelve plantations in Berbice -- nine sugar, one coffee, one

\footnotetext{
${ }^{173}$ Thompson 1987 , op. cit., p. 35.

${ }^{174}$ Williams 1950, op. cit., p. 9.

${ }^{175}$ Thompson 1987, op. cit., p. 41.
} 
cotton, and one cocoa -- and one hundred and twelve were in the hands of private owners. ${ }^{176}$

In 1746, Laurens Storm van's Gravesande, the Governor of Essequibo and one of the colony's most capable Dutch administrators, threw open the Demerara region to settlement. ${ }^{17}$ Thus far, Demerara had been virtually ignored. At the onset of Gravesande's administration, it was nothing more than a trading area patrolled by the company's traders, distinguished by two trading posts, and only haphazardly governed from Kijkoveral. ${ }^{178}$ Furthermore, the river was not as navigable upstream as either Essequibo or Berbice. ${ }^{179}$ This was an important point, given the safety concerns of the settlers; however, with the lull in European rivalry, Gravesande felt it an opportune moment to establish settlement in this part of the country. ${ }^{180}$ No doubt his hand was also forced by the fact that all available land in Essequibo had already been awarded. The first Demerara concessions were granted in April 1746, and by the following year eighteen large sugar p. 68 .

${ }^{176} \mathrm{King} 1968$, op.cit., p. 38 and Netscher 1888 , op.cit.,

${ }^{177}$ Harris and Villiers 1911, op. cit., p. 26

${ }^{178}$ Ibid. , p. 66.

${ }^{179}$ Dalton 1855, op. cit., p. 223.

${ }^{180}$ Ibid. , pp. 223-224. 
plantations and a few smaller ones had been occupied. ${ }^{181}$ Gravesande immediately recognized that the future of the colony rested with Demerara and expressed his views to the DWIC's Directors in Holland: "I doubt not but that this River Demerary will in a few years be as populous, if not more so than Essequibo."182 Two years later, in a despatch of December 2, 1748, Gravesande informed his superiors of a sugar cane harvest "beyond all his expectations" and reiterated his prediction that Demerara would supersede Essequibo. ${ }^{183}$ The colonists initially purchased land in the higher reaches of the river, some fifteen to twenty miles from the estuary, as their predecessors had done in Essequibo. This may appear surprising, since from experience in Essequibo they must have been aware of the potential richness of the coast; but, the fear of naval attacks, the high costs involved in empoldering and draining the coastal lands, ${ }^{184}$ the lack of fresh water downriver, and the availability of creeks which could be utilized to generate power were outweighing factors in the settlers' calculations. ${ }^{185}$ To ease fears and to offer some degree of protection for the new colonists, Gravesande built a

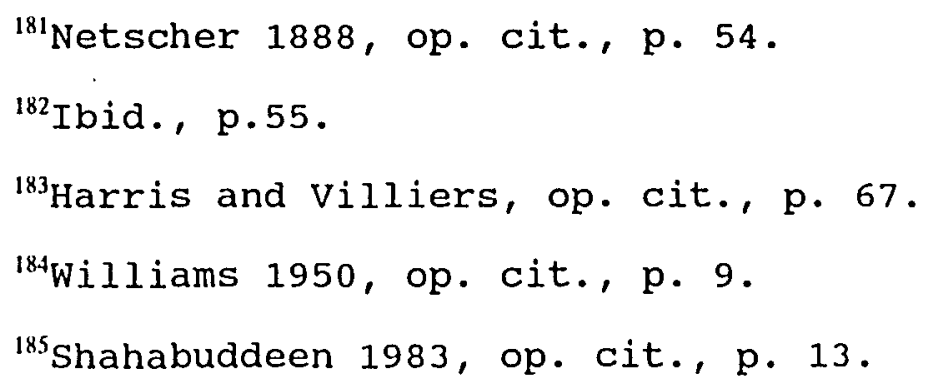


brandwagt or guard house/signal station at the mouth of the river. ${ }^{186}$

Thus Essequibo's decline had begun. The DWIC's indigo plantations in the colony were abandoned; and Kijkoveral, having been allowed to deteriorate, was finally demolished. ${ }^{187}$ By 1752 settlement on the Demerara was outstripping that of the older colony. Plantations on the east bank were stretching as far down as the Garden of Eden, by the following year (1753) they had reached Diamond, and by 1759 the area now known as Georgetown was occupied by the following plantations: Vlissengen, La Bourgade, Eve Leary, Ruimveldt, La Penitence, and Jerish Hope (Werk-en-Kust).i88 Cultivation continued to spread, and by 1769 all the land on both banks of the Demerara River were occupied and under some semblance of cultivation. Demerara could now boast of 130 plantations, whilst only 70 could be found in Essequibo. ${ }^{189}$

In Demerara the number of acres under cultivation was only a fraction of the total available acreage. Land speculation had been a problem since Gravesande had opened up the Demerara region in 1746 , on generous terms to members of all nations. Poll tax exemptions on slaves and generous

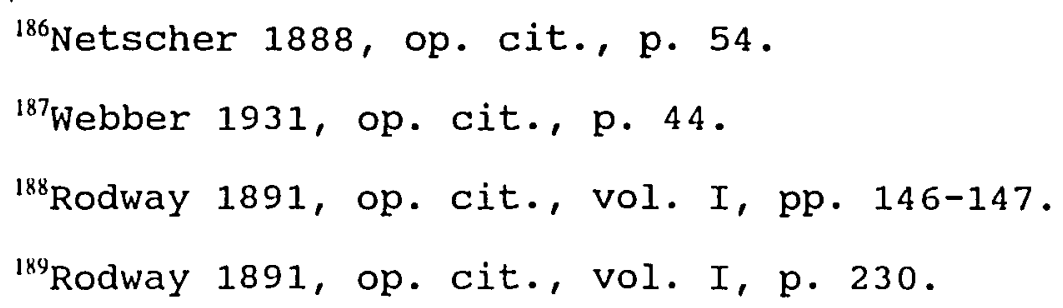


quantities of land were a windfall to European capitalists, many of whom had no interest in cultivating their holdings. Fearing a moribund agricultural economy, the DWIC in July 1752 determined that no one could acquire a 2,000-acre concession unless a sugar mill was added within three years. Grants of land were generally no more than 1,000 acres for cane or 500 acres for other crops, with each owner being required to build a house on the property and to begin planting within eighteen months. In 1761, it was resolved that no individual could sell his estate until it had been in his possession for five years. ${ }^{190}$

Berbice similarly had attracted specuiators, and the colony was purported to have between 113 and 125 estates in 1749, some of which were idle. ${ }^{191}$ In an effort to curb speculation, the directors sought to limit concessions to 500 acres and to charge a fee of ten guilders per acre. ${ }^{192}$ As a result, speculation was curtailed.

The quest for fertile agricultural lands in Demerara reached such a pace that in 1775 the DWIC began the excavation of Canal No. 1 on the west bank of the Demerara River. A little later, Canal No. 2 was completed on the west bank and Canal No. 3 on the east bank. Demerara's

\footnotetext{
${ }^{190}$ Ibid. , p. 139.

${ }^{191}$ Thompson 1987, op. cit., p. 41 .

${ }^{192}$ Ibid.
} 
appeal was such that the newly open lands were immediately taken up. ${ }^{193}$

Europeans of all nationalities arrived to seek their fortune, but the majority of newcomers were English speculators from the West Indies. ${ }^{194}$ Downriver and northwards from Canal No. 3, the following plantations were in existence on the east bank by 1777: Zorg-en-Hoop, Ruimveldt, La Penitence, Le Repentir, Werk-en-Rust, La Bourgade, and Eve Leary. ${ }^{195}$ At the end of 1783 the entire area from the Demerara River eastward to Mahaica along the coast had been allotted. Eight years later the entire coast from the Pomeroon in the west to the Abary in the east had been alienated and planted with coffee, cotton, or sugar cane. ${ }^{196}$

Downstream migration was to be pivotal in the country's economic and settlement history. Movement to the more fertile coastal lands, which frequently lie below sea level at high tide, presented some severe difficulties. The lack of adequate natural drainage necessitated a tremendous expenditure of capital and labor to construct and maintain the elaborate system of drainage and irrigation needed to keep out the murky waters of the Atlantic. Thus, only the

\footnotetext{
${ }^{193}$ Netscher 1888 , op. cit., pp. 67-68.

${ }^{194}$ Dalton 1855. op. cit., p. 238 .

${ }^{195}$ King 1968, op. cit., p. 38 .

${ }^{196}$ Rodway 1893, op. cit., vol. II, p. 57.
} 
wealthiest planters were able to shoulder the requisite outlay of capital. And it is from this group that the plantocracy, which was to play such a vital role in Guyanese urbanization, emerged.

The geographic nature of the coastlands resulted in a change in the class of proprietors. Small-scale peasant farmers simply did not possess the resources needed to cultivate land on the coast. Planters who ventured to the coast were compelled to increase the size of their undertakings by utilizing large areas of land, and to concentrate solely on staples for export to recoup capital expended on sea defense and reclamation. Capital and other inputs were provided by European merchants whose basic association with the planter was a client-debtor relationship. Ultimately it was the indebtedness of the planters to the merchants which ensured the fall of the planter class.

\section{Political and Social structure}

A social process such as urbanization is the manifestation not only of economic relationships, but also of political and social ones among groups within the society. These relationships produce a specific urban history among several possible histories. A grasp of the political and social structure, therefore, is vital for understanding urbanization, particularly as it relates to infrastructure and urban development. As a result, this 
sub-section discusses how the political and social structure developed and examines the changes during the early colonial and slave plantation period.

Governmental organization in Guyana began as a system of administration designed for the regulation of trade depots in the colony, with strict emphasis being placed on the production of dividends for the DWIC. Kijkoveral was designated as the administrative center of the colony of Essequibo, and it was here in 1639 that the DWIC assigned Jan van der Goes the title of "commander" of the settlement. ${ }^{197}$ The commander was merely the chief DWIC orficer in the colony, entrusted to manage the affairs of the company. In 1690 the company's estates had increased to such a point that each required its own manager. An organization known as the council, consisting of the commander, managers, and a secretary was formed to handle the additional responsibilities of an expanding community. "Free" planters had steadily been increasing in numbers, but they were excluded from the colony's decision-making body. ${ }^{198}$

The name of the Council was changed in 1718 to the Council of Policy and Justice. The free planters, who now 97.

${ }^{197}$ Report of the U.S. Commission 1897 , op. cit., pp. 96${ }^{198}$ Clementi 1937, op. cit., p. 26. 
numbered fifteen, were still unrepresented; ${ }^{199}$ their interests were deemed to be subservient to those of the DWIC, which firmly maintained that its officers must be completely in command of the colony. Supreme authority remained in the metropole, and the local body was bound to faithfully execute even the most trivial instruction.

Berbice appears to have been generally ignored by the DWIC until 1627, when its charter expired and a new one was granted by the Dutch government to Abraham van Pere. Throughout the seventeenth and early eighteenth centuries, Berbice was administered as a proprietary colony without any semblance of a representative assembly. Furthermore, there is no evidence that inhabitants of the colony ever agitated for representation. It was not until 1732 that the states-General of the Netherlands finally promulgated a constitution for Berbice. The constitution provided that the affairs of the colony were to be administered by a governor commissioned by the statesGeneral. The governor was to be assisted by a council of Government, consisting of six persons, three of whom were to be chosen by the governor from a number of names submitted to him by inhabitants with a certain property qualification. The Council of Government was charged with performing both executive functions and criminal justice. civil cases were to be handled by a Council of Justice, with the governor as

${ }^{199}$ Ibid. 
president and at least six other members nominated by the governor and the Council of Government. ${ }^{200}$

Bernard Waterman was appointed Berbice's first

governor on March 24, 1733. Upon his arrival in Berbice, he established the Council of Government and the council of Justice. Both of these institutions were located at Ft. Nassau, the seat of government. ${ }^{201}$ with improvements in the colony's administration, many settlers found Berbice an attractive prospect. Grants of free land may have also played a part in luring prospective settlers. Such was the demand that it soon became necessary to set a price of ten florins per acre. ${ }^{202}$

Essequibo, similarly, was at this time experiencing an influx of private planters. Since they were proprietors, members of the militia, and taxpayers, it was understandable that private planters should demand access to an institution in which their views could be entertained. ${ }^{203}$ As a result, the political structure was modified in 1739 to allow settler representation. The DWIC enacted legislation requiring the Council of Policy and Justice to increase its

${ }^{200}$ Im Thurn, E. 1883. "Essequibo, Berbice and Demerara under the Dutch." Timheri II, p. 337 .

${ }^{201}$ Ibid. , p. 337 .

${ }^{202}$ Clementi 1937, op. cit., p. 89.

${ }^{203}$ Rodney, w. 1981. A History of the Guyanese Working People, 1881-1905. Baltimore: John Hopkins University Press, p. 120 . 
membership from four to six, one of whom was to be chosen by the governor from amongst the private planters. ${ }^{204}$ Thus, the Council of Policy and Justice was transformed from an administrative institution to one which was additionally concerned with representation, legislation, and adjudication. At the same time the seat of government was moved from Cartabo Point to Flag Island (renamed Fort Island) on the Essequibo River.

In 1743 Storm van's Gravesande, who had recently been appointed commander, created a College of Kiezers, or electors, for the singular purpose of nominating representatives of the private planters to the council of Policy and Justice. ${ }^{205}$ Membership in the College of Kiezers was for life, and members were elected by the resident planters possessing more than twenty-five slaves. ${ }^{206}$

Although Berbice and Essequibo were under the umbrella of the Dutch government, they remained separate political units. In 1746 Gravesande opened the Demerara region and a third colony entered the fray. The growth of Demerara was so rapid that by 1750 the Dutch felt obliged to assign the colony a separate commander. However, the two colonies continued to share a Council of Policy and a council of

\footnotetext{
${ }^{204}$ Rodway 1891, op. cit., vol. I, p. 102 .

${ }^{205}$ Clementi 1937, op. cit., p. 28 .

${ }^{206}$ Great Britain. Colonial office. 1951. Annual Report on British Guiana. London: H.M.S.O., p. 5.
} 
Justice (both formed by a separation of the Council of Policy and Justice). The primary purpose of the Council of Policy at this time still related to the development of the company's business and the granting of land concessions.

Among the regulations passed during this period was one which prohibited slaves from traveling about the river without passes. ${ }^{207}$ Restriction on movement was an attempt to prevent slaves from forming independent settlements and communities.

The early eighteenth century witnessed an increase in plantation agriculture and a corresponding decline in trading activities. Migration towards the coast resulied in widespread improvements in the plantation economy, and the need for drainage and irrigation. However, the large outlay of capital necessary to empolder the coastlands made it prohibitive to the small planter. As a result, the plantocracy was transformed. Only the wealthiest planters were able to cultivate estates in the colonies, and these soon began to agitate for a greater involvement in government decision-making. In 1767 the constitution of the Council of Policy was altered to enable two representatives of the private planters to take up seats in the council. ${ }^{208}$ Demerara's increasing importance was acknowledged, and the colony was granted a separate Council of Policy and a

\footnotetext{
${ }^{207}$ Rodway 1891, op.cit., vol. I, p. 132 .

${ }^{208}$ Shahabuddeen 1978 , op. cit., p. 22.
} 
Council of Justice. In Essequibo and Demerara, each Council of Policy included four private planters and four DWIC representatives, with the Director-General having the casting vote. The additional private planter representation on the council was a clear indication of the increasing influence and wealth of the plantocracy.

Religious and moral structures and sanctions were almost nonexistent in the colonies. Much of the profits from the plantations was directed overseas to these absentee landlords, who could not persuade themselves to live in Guyana any longer than was necessary. They came primarily to make their fortunes and had little interest in maintaining or developing the country's political structure or social life.

in the ensuing years, control over expenditure became a bone of contention between the private planters and the representatives of the DWIC. Taxes levied on the private planters were deposited into an account known as the company Chest, but the increasing cost of administration made it necessary to raise additional revenues. The conventional poll tax was therefore supplemented by a customs duty of two percent, which barely offset/the increase in company expenses. ${ }^{209}$ The DWIC, as a result, developed a system in which additional taxes for special purposes could be raised

\footnotetext{
${ }^{209}$ Lutchman, H. 1974. From Colonialism to Cooperative Republic: Aspects of Political Development in Guyana. Rio Piedras, Puerto Rico: University of Puerto Rico, p. 13.
} 
with the consent of the planters. Taxes levied in this manner were deposited into a separate account known as the Colony Chest. Periodic efforts by the DWIC to increase taxes for either chest were strenuously resisted by the planters, though in time agreement to increases in taxes for the colony chest proved to be less contentious than for its counterpart.

The British and French invasions in 1781 and 1782 interrupted the rift that was evolving between the planters and the company. The French complained that the company was too greedy and that it took no interest in the colonies. ${ }^{210}$ French rule, however, was deeply urpopular. Planters felt disenfranchised; the councils were rarely consulted, and the fact that the French installed officials of their own nationality in all chief positions only served to increase hostility.

In the aftermath of the occupations, in 1784 the States-General in the Netherlands resolved to unite the Councils of Policy of Essequibo and Demerara. The councils were linked, and the inhabitants instructed to hold all meetings at stabroek, the new seat of government. ${ }^{211}$ Essequibo, however, was to retain its own court of Justice at Fort Island, the capital of that settlement.

\footnotetext{
${ }^{210}$ Rodway 1893, op. cit., vol. IT, pl. 14 .

${ }^{211}$ Clementi 1937, op. cit., p. 240 .
} 
The 1780s proved to be a period of intense conflict between the planters and the DWIC and its officials in the colony. Planter resentment was brought to the fore by the decision to raise the poll tax on slaves from two-and-a-half guilders to six guilders, and by a proposal that their representatives to the Council of Policy and Justice be reduced to three. The planters responded by failing to attend council meetings when summoned, and by withholding all increases levied. The result was that the company was unsuccessful in recovering taxes for the years 1784 to $1786 .{ }^{212}$

Planter complaints became so insistent, and the number of petitions to Holland so numerous, that a committee was formed to investigate all grievances. ${ }^{213}$ The committee formulated its recommendations in a report known as the "Concept Plan of Redress." The report provided that there should be a single court of Policy for Essequibo and Demerara, to consist of the Director-General, four exofficio members, and four colonists (two from Essequibo and two from Demerara). This provision restored some degree of leverage to the planters, but the casting vote was retained by the Director-General.

The elected members of the court of Policy were chosen through a college of Kiezers, from among colonists

\footnotetext{
${ }^{212}$ Ibid. , p. 44.

${ }^{213}$ Ibid., p. 243 .
} 
possessing twenty-five or more slaves. The size of the College of kiezers was increased to seven in both Essequibo and Demerara, and members were elected for life by colonists having at least twenty-five slaves in their employ. ${ }^{214}$ Qualification requirements for both the court of Policy and the college of Kiezers ensured that political decisionmaking would be in the hands of a relatively small planting oligarchy. Economic muscle in the planting realm was utilized to concentrate power in the political realm. The identity of interest, in turn, reinforced a social structure founded on the plantation, and one which confined Guyana to a history of uneven development.

Shortly after the Concept Plan was put into operation, the states-General revoked the charter of the debt-ridden DWIC. On December 31, 1791, after 175 years in Guyana, the company finally wound up its operations. ${ }^{215}$ At the start of the new year, the two colonies were amalgamated under the title of the "United Colony of Demerara and Essequibo," with a single administration over which the states-General exercised executive and legislative power. The designation Director-General was changed to Governor, and Baron van Grovestnis assumed the new position.

Following the outbreak of the French Revolutionary Wars, the Batavian Republic was established in Holland in

\footnotetext{
${ }^{214}$ Ibid. , pp. 44-45.

${ }^{215}$ Ibid. , p. 47 .
} 
1795. The Governor, van Grovestnis, an ardent supporter of the Prince of Orange, relinquished his position in protest of the Court of Policy's decision to support the Republicans. During the upheaval, a slave insurrection occurred which necessitated raising funds to quell the disturbance. Without a governor, it was decided on June 3, 1795, following a joint session of the court of Policy and the college of Kiezers, that the Colony Chest should be regulated by a special Combined Council comprised of the "unofficial" members of the court of Policy and four Kiezers, two each from Demerara and Essequibo. In somewhat difficult circumstances, the planters were able to manoeuvre themselves into a situation whereby control of taxation became their responsibility.

When the British invaded the colony in 1796, they agreed to uphold the "ancient laws and usages" of the colony..$^{216}$ The planters demanded that the Combined Council should be a part of the new constitutional arrangements. However, the British felt that the institution was not an integral part of the Plan of Redress. They ruled against the planters, but sought to soften the blow by formulating a proposal for the election of six Financial Representatives. The Financial Representatives were allowed to sit with the members of the court of Policy in a "Combined Court," and

${ }^{216}$ Dalton 1855, op. cit., pp. 243-244. 
were granted the right to vote on matters relating to the raising of taxes and the examination of accounts. ${ }^{217}$

Financial Representatives, unlike their counterparts in the court of Policy, were to be elected on an at-large basis by residents possessing twenty-five or more slaves. ${ }^{218}$ once again the plantocracy had managed to mold the colony's constitutional framework so as to maintain its hegemony.

The inaugural meeting of the Combined court was held on November 2, $1796 .{ }^{219}$ It soon became apparent that the plantocracy, by virtue of its powers in the newly established court, occupied a position from which it could dominate the economic structure of the colony. They possessed the ability to decide whether money should be raised to keep the capital in good repair; maintain roads and bridges; construct sea defenses; provide education; and improve the water supply, public health and welfare. ${ }^{220}$ Members of the court, however, were reluctant to raise revenue unless they could profit from the outcome: for example, several times the court of Policy had published regulations for roads and bridges, but these regulations were only partially complied with. The roads, up to the nineteenth century, were only bridle paths, which were all

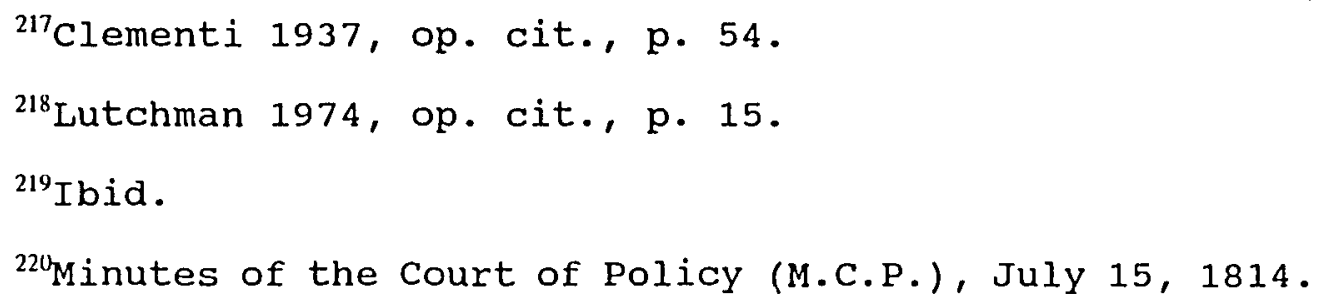


that the planters wanted, since goods were invariably transported by water. ${ }^{221}$ The towns too were virtually ignored. Only a few retail traders lived there, and they were virtually powerless. Most of the colony's supplies were brought in by the planters themselves. Such professional people as there were appear to have been of low social standing; for example, the surgeon was also the barber. In short, the only importance of the towns arose from the fact that they were the centers of political activity and administration. The governor and colonial officials resided in them; and when there was legislative business, the elected members of the Combined court or court of Policy gathered there. The civil and criminal courts were also held in the towns. ${ }^{222}$ Thus, in the Combined court, one was hard-pressed to find support for urban development.

In Berbice the constitutional arrangements were not as democratic as those of its sister colony. The planters were not as powerful, and councilors were not elected but assigned their positions by the governor. Nevertheless, Berbice towns also received scant attention, primarily because during periods of occupation the colonies were administered jointly, with Berbice playing the role of a junior partner.

\footnotetext{
${ }^{221}$ Rodway 1891, op. cit., vol. I, pp. 57-58.

${ }^{222}$ Im Thurn 1884, op. cit., Part III, p. 22.
} 
Berbice and Demerara-Essequibo were returned to the Batavian Republic after the Treaty of Amiens in 1802. The return of the Dutch created a good deal of civil and political chaos. Many of the British and some of the Dutch planters were unhappy at the new turn of events. Pressure was brought to bear on the British government, which responded by finally taking back the colonies in 1803.223 Such were the feelings in the colonies that the resistance offered was little more than perfunctory.

Under the terms of the 1803 capitulation, the British guaranteed to the residents of the colonies that:

...the laws and usages of the colony shall remain in force and be respected, the mode of taxation now in use be adhered to and the inhabitants shall enjoy the public exercise of their religion in the same manner as before the capitulation. ${ }^{224}$

The transition to British rule therefore did not involve any great changes in the social and political structure of the colonies. The existing constitutional framework remained intact. The planter-dominated combined Court preserved its right to raise taxes, whilst the court of Policy remained the legislative and executive body controlled by the governor and officials of the British government.

\footnotetext{
${ }^{223}$ Clementi 1937, op. cit., p. 259. ${ }^{224}$ Ibid. , p. 57 .
} 
Planters in Berbice were not entirely happy about some of the new developments. They complained that the port of New Amsterdam, the capital of Berbice, was being deprived of shipping trade by the fact that supplies were being shipped to Britain via Stabroek, Demerara, and not New Amsterdam.

The Financial Representatives of the Combined court in time began to agitate for an extension of their power and privileges. They urged that they be given control over expenditure as well as taxation, and in september 1812, they were inadvertently granted this prerogative by Lieutenant Governor Hugh Lyle Carmichael. ${ }^{225}$ Carmichael, a fervent British nationalist, sought to eliminate Dutch political influence in the college of Kiezers by combining that institution with the Financial Representatives, and extending the suffrage to include those who paid taxes on an income of 10,000 guilders, this being deemed equivalent to the slave-owning qualification. Carmichael hoped to squeeze out the Dutch by adding to the voters' list members of the professional and commercial classes who were mainly British. ${ }^{226}$

Carmichael's revamping of the constitution had profound repercussions which the governor probably failed to anticipate. The combination of Financial Representatives and Kiezers resulted in the elective members of the combined

\footnotetext{
${ }^{225}$ Lutchman 1974, op. cit., p. 15.

${ }^{226}$ Clementi 1937, op. cit., pp. 61-62.
} 
Court outnumbering the official section ten to four. The elective section now had control not only of taxation but also of expenditure. The home government was not consulted prior to Carmichael's actions; and when word of the changes reached England, Lord Bathurst, the Colonial Secretary, severely admonished the Lieutenant Governor. Carmichael was instructed not to introduce any new constitutional changes without consulting the metropolitan government and was informed that his actions were unconstitutional. Nevertheless, Bathurst did not move immediately to repeal the new law. 227

The new $\perp y$ enfranchised merchant class had begun to make their presence felt to such an extent that Governor D'Urban, a supporter of the planters, recommended to the Colonial secretary the removal of the income qualification. On March 5, 1831, approval was granted to restore the franchise to its pre-Carmichael days, that is to say, ownership of twenty-five or more slaves.

Berbice, Demerara, and Essequibo were finally united as a single colony on July 21, 1831. In a despatch to sir Benjamin D'Urban on March 18, 1831, the secretary of state of the colonies outlined the metropolitan government's rationale for the union of the colonies:

The Ministers of the crown are persuaded that they could not advise a more useful exercise of the Royal prerogative, which has been retained in these

${ }^{227}$ Ibid. , p. 62 . 
colonies, than in combining the whole body of inhabitants into one society, connected by common laws and institutions, as they are already connected by a community of origin, language and rural economy. ${ }^{228}$

The constitution, which unified "British Guiana" in 1831, derived its characteristics from Demerara and Essequibo and thus favored the plantocracy. The income qualification introduced by Carmichael was abolished and the Court of Policy was enlarged to include a member from Berbice, as well as one official member. ${ }^{229}$ Given their lack of representation, the union of the colonies did not gain unqualified support in Berbice. A general feeling existed that Berbice's interests would be relegated to those of Demerara in particular. The union had already resulted in Georgetown becoming the center of administration.

Slavery as a legal institution was abolished on August 28,1833 , when it received the royal assent, but the law did not come into effect in Guyana until August 1, 1834. The ex-slaves, however, did not gain their complete freedom. Children under six years of age were immediately freed, but all those who were older were required to serve an unpaid period of apprenticeship for their former masters. A sevenand-a-half hour work day was arranged for all apprentices, with praedials commanded to serve six years and non-

\footnotetext{
${ }^{228}$ M.C.P., Aug. 3, 1831.

${ }^{229}$ Ibid.
} 
praedials four years. The remainder of the working day, apprentices were allowed to work for wages. ${ }^{230}$

According to the planters, apprenticeship was meant to prepare the ex-slaves for freedom. In reality, it a was traumatic period for the Africans. Planters used the time to get as much as they could out of a labor force which they firmly believed would retreat into the bush, or appropriate vacant coastal lands, once complete freedom was attained. During the first month of apprenticeship, 70 men and 135 women were gaoled. The greater number of women sentenced stems from the fact that men were usually whipped and returned to the plantations. ${ }^{231}$ Government officials, especially the judiciary, were closely aligned with the plantocracy. Many judges simply ignored grievances filed by the apprentices. During November 1837, 129 complaints were lodged, charging planters with assaults, destruction of property, inadequate housing, ill treatment of pregnant women, and a variety of other crimes. Of these only twentyfive guilty verdicts were returned, and fines ranging from thirty shillings to five pounds imposed. An astonishing 102 cases were found to be "frivolous" and were thrown out. ${ }^{232}$ Slave society revolved around the planter. Slaves of course were completely subservient to him; tradesmen and

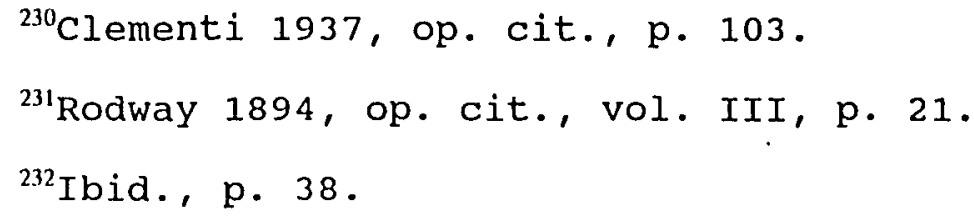


merchants depended on him to purchase their goods; professional persons looked to him for employment; whilst government officials found his patronage to be irresistible and therefore were anxious to maintain a cozy relationship with him. Efforts to attain the social status of a planter often led members of the professional and merchant classes to engage in agricultural pursuits - such was the standing of the planter in the colony.

Emancipation rendered a change in the Guyanese constitution. Hitherto the franchise had been confined to those owning at least twenty-five slaves; but with slavery outlawed, the qualification was altered to include all males who paid taxes on an annual income of 143 pounds or who paid five pounds in direct taxes. The change was not as revolutionary as might be expected. Taxation in Guyana was mainly through customs duties and indirect; therefore, franchise qualification levels were set at a rate which effectively exciuded the vast majority of the population. ${ }^{233}$

Though the British government was generally supportive of the plantocracy, there were instances of conflict between the colonial state and the planters. A major constitutional crisis erupted following emancipation in 1834. Prior to the abolition, a chief source of revenue was the King's chest, formerly the Company's chest, a poll tax on slaves. Since this method of financing was now redundant, the metropolitan

$$
{ }^{233} \text { M.C.P. , Dec. 2, } 1838 \text {. }
$$


government formulated a plan to combine the King's chest and the Colony Chest, and to place this fund under the auspices of the combined Court. In return, the British government requested that the combined court pass a civil List for seven years which would cover the salaries of government officials. The combined court rejected the proposal and declined to authorize a civil List for two years. A compromise was eventually reached in 1836 when the Combined court was given the right to examine annual expenditures as well as taxation, a function it had performed after Carmichael's reforms of 1812 but had relinquished after the union in 1831. The combined court in its turn agreed to pass a civil List to run until 1840 .

The Amerindians had been utilized as an interior police force geared to the capture of runaway slaves, but now that slavery had come to an end the meager annual expenditures allotted to them were canceled. Amerindians were no longer regarded as part of the body politic and from this instance were largely ignored.

Slavery had been the cornerstone of the country's social and political structure. Colonial society was stratified via a fusion of race and class. At the top of the social hierarchy was to be found the white planter and his white entourage of government officials, professionals, and merchants. In the middle were manumitted slaves (generally mulatto) and white plantation overseers, clerks, 
and artisans. At the bottom, supporting the whole system, were the African slaves, who were themselves separated by class distinctions. The house slaves, the factory workers, and those in the skilled trades - blacksmiths, coopers, carpenters, masons and boat builders - occupied the apex of this subsystem. At the base were the field slaves, who were by far the most numerous element in society. Naturally, field slaves were to be found on the plantation and away from the fledgling urban centers. The key question was: Where would they go once complete freedom had been attained?

\section{SUMMARY}

Throughout the period a policy of laissez-faire was largely maintained. The growth of Georgetown and New Amsterdam was by and large allowed to be accompanied by the expansion of the built-up area. The Dutch initially paid little attention to the development of the country and urban areas in particular. Colonization centered on the plantations. No encouragement was given to the growth of towns and the development of manufacturing industry.

Planning was perfunctory and a wholly physical exercise. Physical plans were drawn up for all the early administrative centers. For example, after Kijkoveral was found too inconvenient to accommodate company officials and the military, Cartabo was surveyed and laid out into 
building lots. Likewise, Borsselen was laid out in twentyfour lots.

As the period of slave plantation society was nearing its end, the society was no longer markedly polarized into white/planter-black/slave relationships. The urban structure also mirrored the changing sociopolitical makeup of the society. Most notably, there was an increase in the number of coloreds. This group were rarely field hands; most of them worked in the great houses of the estates and in the towns. Consequently, as time progressed, political and economic differences between town and country were likely to take on racial overtones. A good many of the relationships which were to typify twentieth-century Guyanese society were formulated during this period of slave plantation society. For example, there was the command of white over black, planter over slave, core over periphery, and towards the end of the period, town over country.

Georgetown was irrevocably consigned as the major urban area due to an intensification of external trade and accumulated riches via the production of sugar. Up to the end of the period, Georgetown and New Amsterdam were the only two identifiable towns. Mahaicony and Mahaica on the Demerara coast and Aberdeen on the Essequibo coast were the only villages in the entire country. In reality these three settlements were tiny fishing villages, local community service centers, and military outposts created in a period 
of impoverished internal communications. On the whole, the country was outward-looking, with urban development confined to Georgetown. 
CHAPTER III

POST-EMANCIPATION AND INDENTURESHIP 1838-1917

GLOBAL LINKAGES

This section on the post-emancipation and indentureship period details how dependence on Holland was exchanged for dependence on Great Britain, and to a lesser extent the United states during the period from about 1838 until the First world war. It considers the changes in the destinations of exports and the influence of port traffic on Georgetown's and New Amsterdam's development trajectories. The outbreak of World War I disrupted the country's link with the core and created new market opportunities which are detailed in this section.

Guyana's dependent economy and its incorporation into the modern world system economy meant that sugar, and hence the entire society, was subject to external events, particularly conditions at the center. Unstable markets, price fluctuations, foreign wars, and metropolitan political and economic policies dominated events in Guyana. For example, in the 1840s, just when the sugar industry was 
recovering from the setback of emancipation and attendant labor problems, the Government of Great Britain passed the Sugar Duties Act of 1846, which removed preferential tariffs on colonial produce and allowed slave-produced sugar from Brazil, Cuba, and other foreign countries to compete with Guyanese sugar in the British market. Then in 1847, bumper sugar harvests were reported throughout the West Indies and Mauritius, and this surplus resulted in a serious glut of sugar in a British market that was already being swamped by foreign-grown sugar. The depression which ensued was one of the most serious in the history of the country. According to a contemporary writer, Dalton, "the panic of 1847 will be long remembered and long felt."1

In the post-emancipation and indentureship era Guyanese exports were almost exclusively sugar and its byproducts, rum and molasses; and these in turn were shipped, almost without exception, to the United Kingdom. Over 90 percent of the country's exports were destined for the British market. Dependence on Britain was at times alleviated through exports to the United States, Canada, and the British West Indian Islands, but these were only significant in the latter part of the nineteenth century. For instance, the United states represented a possible alternative for Guyana's sugar in the 1840s, but exports into that country were curtailed by the American tariff of

\footnotetext{
'Dalton 1855, op. cit., vol. II, p. 24.
} 
1846, which imposed duties of 30 percent on sugar and 75 percent on rum. As a result, Guyanese exports to that country failed to rise above 1 percent of total exports between 1838 and 1851. Guyana was, however, importing a large amount of food from the United states at this time. According to a 1850 report to Governor Barkly:

A great trade in provisions is carried on with the United States of America, upon which this colony is almost entirely dependent for food notwithstanding that the villagers could with ease not only raise sufficient for home consumption, but could also supply the neighbouring islands. ${ }^{2}$

The introduction of cheap American food into the colony was an important weapon, utilized by the plantocracy, to hinder the development of a viable peasant-producing economy in Guyana, and to keep emerging African-Guyanese villages in a state of dependent underdevelopment with the plantations. Effectively barred from the external market, from which they lacked access and the necessary marketing skills, peasant producers found themselves floundering in an internal market that was dominated by cheap American beef, pork, salted cod, and wheat.

In 1850, sugar exports stood at 26,146 tons; in 1851, they reached 30,124 tons, and continued increasing annually until they reached 50,643 tons in $1861 .^{3}$ The decade of the

${ }^{2}$ Report to His Excellency Henry Barkly. The Report of the Commissioners Appointed to Inquire into and Report upon the Condition and Prospects of the Colony of British Guiana. 1850 . In Dalton 1855, Appendix.

${ }^{3}$ B. B. , $1850-1861$. 
1860s witnessed widespread expansion of the sugar industry. Exports of sugar in the period increased markedly, from 50,643 tons in 1861 to 72,943 tons in $1871 .^{4}$ In the early years of the decade, the United Kingdom was still responsible for nearly 90 percent of the country's exports; but during the latter part of the 1860s, dependence on British markets declined when the United States became a major export outlet. The Guyanese planter preferred the infant American market, because he was guaranteed cash on delivery, whereas in England, payment was generally slow in coming, and the laws governing sugar exports much too cumbersome. By the late 1360s, the United States represented almost 33 percent, and Britain 55 percent, of Guyanese exports.

Changes in the destination of exports were accompanied by a transformation in the structure of ownership in the sugar industry. Family ownership of estates were replaced by new corporate ownership, so that by 1871 , only one-tenth of the 136 estates left in the country were being managed by resident proprietors. ${ }^{5}$ The increased overseas domination merely served to tighten the existing global linkages between Guyana and the core.

In 1884 the world-wide slump in sugar prices, and the depression which subsequently followed, meant that the

\footnotetext{
${ }^{4}$ B.B., 1861 and 1871.

${ }^{5}$ Des Voeux Commission Report, 1871, p. 77.
} 
planters, fearing massive unemployment and unrest, were forced for the first time to contemplate alternative employment opportunities in Guyana. As a result, the rice industry and gold mining were allowed to emerge to cushion a potentially disastrous situation.

Within the sugar industry, there was a marked decline in the number of sugar estates in the 1880s. However, this does not adequately apprise one of the state of sugar in Guyana. Problems were being encountered on the demand side (i.e., in the metropolitan markets), but the supply of sugar had actually increased between 1881 and 1891, rising from an export figure of 92,323 tons to 116,968 tons. ${ }^{6}$ The industry had become more productive and yet it was in the midst of a depression.

Georgetown's and New Amsterdam's development trajectories were undeniably dependent on external trade with the core. Exports from Guyana in 1884 amounted to $\$ 2,322,032 . .^{7}$ The Port of Georgetown in this year cleared a total of 1,014 ships (668 British and 346 foreign), and New Amsterdam cleared 42 (26 British and 16 foreign).$^{8}$ Two years later, with the recession firmly in place, exports dropped to $\$ 1,842,585 .^{9}$ Meanwhile, the number of ships

\footnotetext{
${ }^{6}$ B.B., 1881 and 1891 .

${ }^{7}$ B. B. , 1884 .

${ }^{8}$ Ibid.

${ }^{9}$ B. B. , 1886.
} 
clearing Georgetown's port fell to 742 (508 British and 234 foreign) and New Amsterdam's to 25 (6 British and 19 foreign). ${ }^{10}$ consequently, both urban areas were unable to undertake badly needed infrastructural projects.

The manufacturing base of Georgetown was simply too inadequate to offset the malaise engendered by the events of 1884. Georgetown's entire manufacturing sector in 1885 consisted of three iron foundries and machines shops, two steam saw mills, the gas works, two woodworking companies, one steam bakery, and two match factories." Manufacturing partially served local needs in the towns and rural areas, and because these were limited, the dependency on the metropole for manufacturing goods was enormous.

New Amsterdam's decline was also attributable to the slump in shipping traffic at its port. The town's status as the country's second port suffered another severe blow with the establishment of a port of entry at skeldon, on the Corentyne coast in $1898 .^{12}$ Ships could now leave Skeldon without having to go to New Amsterdam for customs clearance. In 1911, only 14 ships (1,471 tons) entered New Amsterdam, whilst 952 (8,196 tons) entered springlands (the port serving Skeldon). ${ }^{13}$

\footnotetext{
${ }^{10}$ Ibid.

"B.B., 1885 .

${ }^{12}$ M.C.C., March 11, 1898.

${ }^{13}$ B. B. , 1911.
} 
The outbreak of the First World War rekindled a measure of prosperity in the country, and in the sugar industry in particular. High prices stimulated cultivation, and by 1916 the sugar estates had 92,004 acres under cultivation. ${ }^{14}$ Canada was the major market for Guyanese sugar, with exports totalling $\$ 6,647,063$. The war had also opened the French market for the first time, and $\$ 1,319,673$ of dark crystals (as opposed to yellow) were sent to that country. The following year, the acreage under cultivation increased to 92,$721 ;^{15}$ but whilst Canada remained the most profitable market, France no longer was in receipt of Guyanese sugar. Guyanese economic dependence remained strictly a Canadian, American, and British affair.

The rice industry was also substantially aided by the war. Rice imports from the Far East, the major supplier to the West Indies, were severely curtailed by disruptions in shipping transportation. Guyana quickly filled the niche, and its cultivation and output rose appreciably. In 1914, the area under rice cultivation was 44,889 acres, but by 1917 it had soared to 58,090 acres, with exports reaching 14,367 tons. ${ }^{16}$ One hundred and twenty-one rice mills were operating in the country, 35 in Demerara, 19 in Essequibo, and 67 in Berbice. The war had stimulated the rice

$$
\begin{aligned}
& { }^{14} \mathrm{~B} . \mathrm{B} ., 1916 . \\
& { }^{15} \mathrm{~B} . \mathrm{B} ., 1917 . \\
& { }^{16} \mathrm{~B} . \mathrm{B} ., 1913-14 \text { and } 1917 .
\end{aligned}
$$


industry, and this in turn had opened up some degree of regional trade between Guyana and its West Indian neighbors. Rice exports went not only to the British islands, but to the French and Dutch as well. Previously, regional trade had been little more than marginal. Guyana was attached exclusively to metropolitan markets, but the unexpected conditions of 1914 rendered fresh possibilities.

\section{INDUSTRIAL STRUCTURE}

Emancipation resulted in the decline of certain industries in the plantation economy as well as the development of new ones. This section charts the collapse of cotton, the consolidation of sugar, and the emergence of rice and gold.

The growth of the peasantry following emancipation, accelerated the decline of the plantation economy. In particular, cotton and coffee plantations collapsed in rapid fashion. In 1828, there were 174 cotton and coffee plantations; by 1843, the last exports of cotton were being made; and by 1849 , there were only 16 coffee plantations, and these subsequently collapsed. A commission report in 1850 described the desperate position of certain parts of the country. ${ }^{17}$ In Demerara, the district of Abary "once blooming with fields of cotton" was "now a series of pestilent swamps, overrun with bush, and productive of

\footnotetext{
${ }^{17}$ Report to His Excellency Henry Barkly 1850, op. cit.
} 
malignant fevers." From Mahaicony to Mahaica, the only estate in cultivation was Plantation Farm; the remainder were either abandoned or being used as pasture for cattle. Roads and bridges throughout the county were in a state of disrepair. In many places they were virtually impassable, and as a result a number of estates were cut off, save during the dry season.

Canals Nos. 1, 2, and 3 presented a scene of "almost total desolation." In 1829, Canals Nos. 1 and 2 contained 30 coffee and plantain estates alone, which produced $1,027,120$ pounds of coffee; but in 1850 there were only eight. Of these, five were rented to African-Guyanese, who had fragmented the estates into tiny holdings and were concentrating on ground provisions. Meanwhile the total production of coffee in Guyana amounted to 91,056 pounds in 1849 (Table VIII). This was a remarkable decline, since in 1829 the single plantation of Java alone had produced a crop of 100,000 pounds. The decline was also significant when compared with the country's 1848 production of 318,490 pounds.

Sugar production had also fallen during the 1847-49 period, although for sugar planters the situation was not quite so bleak. Amongst the three counties, however, Essequibo suffered the greatest reverses in agricultural production. Coffee had virtually disappeared, and one-third of the sugar plantations had ceased operations between 1829 
TABLE VIII

COMPARATIVE PRODUCTION OF SUGAR AND COFFEE 1847-1849

Year

1847

1848

1849
Sugar

$$
\begin{aligned}
& 72,407,273 \\
& 64,551,857 \\
& 60,684,454
\end{aligned}
$$

\section{Coffee}

117,021

318,490

91,056

Source: Report to His Excellency Henry Barkly, 1850.

and 1850. Berbice, which was once a thriving cottonproducing region, had abandoned the crop. Sugar remained, but coffee had virtually ceased to exist.

In 1884, following the price collapse of sugar, the rice industry which had been actively suppressed by planters since slavery days was acceded to, though somewhat grudgingly. Rice emerged as a subsistence crop with the aid of the sugar industry, which allowed rice farmers the use of its drainage and irrigation facilities. In 1886, a firm commitment was made to the rice industry when laborers were encouraged to plant 200 acres of rice at Anna Regina, on the Essequibo coast. From this date onwards, the industry gradually expanded in acreage and production. Rice was also grown on the savannah lands behind the estates on East coast Demerara, and on the east coast of Berbice. A new Crown Lands bill also made provision for renting out crown Lands for the cultivation of rice at four shillings and two pence per acre per annum. ${ }^{18}$

\footnotetext{
${ }^{18} \mathrm{~B} . \mathrm{B} ., 1886$.
} 
Planters who had surreptitiously thwarted the gold industry in the early 1860 s now welcomed the discovery of gold in the interior in the 1880s. In 1884, the export of gold was only 250 ounces, but by 1887 it had risen to over 11,900 ounces. ${ }^{19}$ Large numbers of African-Guyanese ventured into the interior as "pork-knockers", ${ }^{20}$ and by 1891 there were at least 4,172 in the hinterland. ${ }^{21}$

From 1881-1891, through amalgamation and consolidation, the acreage under cane cultivation had increased from 77,379 acres to $78,307.22$ In an effort to remain competitive, many estates expended large outlays on improvements in sugar machinery, chiefly in the direction of evaporators, the adoption of which was said to contribute exceptional savings in fuel and labor in an ostensibly labor-surplus economy. Indians living off the estates were chiefly selfemployed in the rice industry. Rice cultivation had been steadily increasing. Between 1884 and 1893 an average of 2,500 acres was devoted to rice cultivation. Thereafter, cultivation expanded to 7,490 acres in $1898,17,300$ acres in 1905, and 30,000 acres in 1911. By 1905 the country was

\footnotetext{
${ }^{19}$ Bronkhurst 1890 , op. cit., p. 61.

${ }^{20}$ Miners cum prospectors.

${ }^{21}$ Census 1891.

${ }^{22}$ B.B., 1881 and 1891.
} 
self-sufficient in rice, and producers had begun to export the staple to the nearby West Indian Islands.

Meanwhile, African-Guyanese who had followed the fortunes of the gold industry into the interior in the $1890 \mathrm{~s}$ were faced with an industry that was in decline in the 1900s. Having already abandoned the villages, the miners, pork-knockers, and mechanics returned from the interior to Georgetown to look for employment opportunities. The city, however, did not have the employment base to absorb this segment of the population. Georgetown was but a colonial city on the periphery, without an industrial base, dependent on commercial, trading, and service activities.

\section{Labor Supply}

Because labor was in short supply during most of the period, this sub-section is devoted to some of the measures taken by planters to retain the work force on the coastal plain.

Subsequent to emancipation in 1838 , labor was an extremely precious commodity. Wages had risen considerably as planters sought to employ scarce labor by bidding against each other in a free labor market. ${ }^{23}$ Many laborers, to the chagrin of the planters, began to form task gangs and to organize for higher wages. Negotiations were handled by a

\footnotetext{
${ }^{23}$ Report of the select Committee of the House of Commons on the Commercial State of the West India Colonies. 1842. No. 479 , p. 4 .
} 
village headman, who contracted the gang out to the planter posing the highest bid. These gangs travelled throughout the coast, and would often hold out for all sorts of inducements before accepting employment. Indeed, many laborers began to withhold their labor by working for a shorter period of time each week. ${ }^{24}$

The planters were in a severe bind, and unable to afford the increased labor costs, they reduced operations. This was reflected in the disappointing production figures of the new post-emancipation era. By 1839 the production of sugar had declined by roughly 30 percent over the previous year, to $61.5 \mathrm{million}$ pounds. It decreased to 54.7 million pounds in 1841, when the planters decided to staunch the downhill spiral. Putting forward a common front, they advanced a plan to reduce production costs by lowering wages to pre-emancipation levels. Furthermore, they revoked a number of in-kind payments. These actions were implemented in a number of ways: stoppage of food and medicine allowances, prohibition of fishing in the trenches belonging to the estates, barring those who left the estates from reaping the crops they had planted, and destruction of workers' pig pens kept on the estates. The few remaining fruit trees, which provided the laborers with an additional

${ }^{24} \mathrm{Grey}$, Earl. 1853. The Colonial Policy of Lord John Russell's Administration. London, p. 57. 
source of food, were cleared away. ${ }^{25}$ Fines were to be imposed for non-compliance of work on the estate, and, perhaps most importantly, laborers who did not comply with any of the above rules faced expulsion from the estate. Strengthened by the discipline of the task gangs, the workers were able to counter-organize and retaliate by launching the first general strike in Guyanese history - in January of 1842 .

The 1842 strike occurred at the start of the crop season. Given the limited labor supply and the fact that indentured immigration was still in its infancy, the planters quickly realized that the only way to avert an impending disaster was to rescind the regulations. Within six weeks, the planters capitulated and the strike was over. For the first time in Guyana's colonial history, the white power structure had been breached. However, the new proletariat did not savor the success of its first industrial action. Tenants on the estates recognized the precariousness of their position vis-a-vis the planters. Lacking the security of tenure, they immediately made plans to leave the estates. This further stimulated the migration from the plantations to the villages, which had been underway since 1838 .

\footnotetext{
${ }^{25}$ Milliroux, M.F. 1843. Demerara, Transition from Slavery to Liberty. Tr. McFarlane, 1877, London, p. 46.
} 
In 1846, sugar prices in Britain fell from 18 pounds to 10 pounds per ton, and this was followed by another industrial cataclysm. ${ }^{26}$ The planters responded to the economic crisis by opting to reduce wages by 25 percent. A strike ensued in December 1847 , but in contrast to the outcome in 1842 , in this strike the workers were defeated within a few months. The labor force had been augmented by immigration, and this shift resulted in a lack of solidarity amongst the workers.

Nevertheless, according to the 1850 commission report, it appears that large numbers of African-Guyanese left the countryside to become freeholders on the east coast and east bank of the Demerara River, near Georgetown, where they could benefit from the town's market and superior facilities. Those who remained soon established their own villages; this move quickly reduced the labor supply necessary for the plantations. On the islands of Leguan and Wakenaam, at the mouth of the Essequibo River, at least 2,000 people were estimated to be living in villages. ${ }^{27}$ Berbice also faced a serious shortage of labor on the plantations. Out of an estimated rural population of 18,000, almost 12,000 were dispersed over small freeholds or were squatting in settlements up the creeks and rivers. ${ }^{28}$

\footnotetext{
${ }^{26}$ Webber 1931, op. cit., p. 217.

${ }^{27}$ Report to His Excellency Henry Barkly 1850, op. cit. ${ }^{28}$ Ibid.
} 
East Coast Demerara was considered to be the most flourishing district in the whole country. This was partly attributable to a number of peculiar circumstances. The Demerara East coast Railway had commenced in 1848 with a line from Georgetown (Cummingsburg) to Plaisance. This new rail line had attracted a large number of African-Guyanese, who had established villages along the line to take advantage of the improved communications with Georgetown. Although these newcomers did not labor continuously on the nearby estates, they did occasionally contribute to the plantation work force. Furthermore, the estates were able to draw labor from Georgetown to supplement shortages in their supply. Estates such as Thomas, Kitty, Bel Air, Enmore, Annandale, Lusignan, Mon Repos, Le Resouvenir, and Ogle were able to continue production on a scale that was comparable to pre-emancipation days. A similar situation existed on East Bank Demerara, near Georgetown. Plantations La Penitence, Ruimveldt, and Houston were able to utilize labor from Georgetown to develop into "three of the finest estates in the colony."29

For Indians, out-migration from the plantations escalated following the collapse of sugar prices in 1884 . Planters saddled with a labor surplus and declining returns began to promote the development of the rice industry. Self-preservation rather than altruism governed the

\footnotetext{
${ }^{29}$ Ibid.
} 
planters' remarkable volte face. Rice not only absorbed surplus labor, but by promoting subsistence it also lowered the cost of labor. Furthermore, sugar planters were able to keep this supplementary labor force on the coast, and at the same time dependent on the estates through their control of drainage and irrigation. This was because rice farming did not generate sufficient income to peasant farmers who were forced to become a semi-proletarianized labor force on the estates. The fact that sugar and rice crops did not compete for labor at the same time meant that the estates were in a position to tap this complementary labor supply should they so wish.

\section{Village Movement}

Although migration to the towns was significant, it did not account for the most important spatial transition in the early years of post-emancipation Guyana. In situations where their former owners were willing and able to pay decent and regular wages, the freed slaves remained as plantation laborers. Indeed, the British Government and the plantocracy had intended for the newly freed slaves to remain on the plantations to labor for wages, but the majority of the ex-slaves were far more enterprising than was anticipated. The ex-slaves were determined to avoid further exploitation on the plantations. After emancipation, they began to purchase land and to establish villages of their own on the Guyanese littoral. This sub- 
section addresses the development and eventual demise of what became known as the village movement.

Villages developed as a result of two distinct methods of land acquisition. The first involved ex-slaves pooling their resources to purchase abandoned plantations, primarily cotton and coffee, in order to set up "communal" villages. ${ }^{30}$ In this type of village, land titles were vested in the form of a single deed, and shares were allocated to the purchasers. The land itself was undivided, and was developed by the group in common. The second method of acquisition resulted in the establishment of "proprietary" villages. ${ }^{31}$ Proprietary villages were formed by proprietors who had purchased their land individually and held titles in their own right. They were located on the front lands of sugar plantations whose far-sighted owners had laid out uncultivated lands into residential lots so that a regular work force could be maintained nearby. The plots of land were deliberately kept small, varying from one-quarter to one-half an acre, so that peasant proprietors would find it exceedingly difficult to be completely self-reliant. Houses were built along the coastal road, and land remaining in the back was used for farming. Hence, settlement morphology was elongated, and this form has continued to the present day.

${ }^{30}$ Young, A. 1958. The Approaches to Local Self-Government in British Guiana. London: Longmans Green, p. 13 .

${ }^{31}$ Ibid. , p. 11 . 
The first communal village was formed in November 1839, when 83 laborers purchased the abandoned 500-acre Plantation Northbrook, on the east coast of Demerara, for $\$ 10,000$. The new owners renamed the plantation Victoria, after the reigning British monarch whom they erroneously believed was responsible for their freedom. In the following year, four more estates were purchased and converted to communal villages on the west coast of Berbice. Plantation Golden Grove, consisting of 500 acres, was purchased for $\$ 1,716$ by 14 laborers; 500 acres of Plantation Litchfield was purchased, by 12 laborers for $\$ 3,000 ; 250$ acres of the eastern half of Plantation Perseverance was acquired, by 109 persons for $\$ 2,000$; and 252 acres of Plantation St. John was obtained, by 46 laborers for $\$ 5,000.32$

Communal villages were located for the most part on the east coast of Demerara, the west coast of Berbice, the west bank of the Berbice River, and the corentyne region of Berbice. In Demerara the explicit focus of village development was within 20 miles of Georgetown, whilst in Berbice a good deal of village development centered on New Amsterdam.

Proprietary villages, on the other hand, were mainly to be found on the Essequibo coast, the west coast of Demerara, and the west bank of the Demerara River. The

\footnotetext{
${ }^{32}$ Ibid., p. 220 .
} 
first proprietary village was founded in Essequibo in 1840, when the owner of Plantations Dageraad, Mocha, and Westfield divided the front lands of these adjacent estates into lots and sold them to the ex-slaves for up to $\$ 200$ each. ${ }^{33}$ Within a short time a flourishing village had come into existence, and was accorded the name of Queenstown, again in tribute to Queen Victoria. Aside from Queenstown, other notable proprietary villages included: Williamstown on the Essequibo coast; Providence, Craig, and supply on the east bank of the Demerara River; Den Amstel and Good Hope on the west coast of Demerara; and Cumberland, Fyrish, and Skeldon in the Berbice region.

The land hunger of the ex-slaves did not go unnoticed by the planters. Plantation Kitty, appraised for $\$ 265,000$ in 1837 , was on the market for $\$ 330,000$ in 1840 . Speculation became rife, so much so that the price for an acre of land almost doubled the pre-emancipation level. In May 1840, Beterverwagting, a 400-acre estate, was sold for $\$ 22,000$, double the price paid for Northbrook, although it was only four-fifths the size of the latter and was located nearby. ${ }^{34}$

The high price of land failed to slow the demand by the ex-slaves, and by 1841 the "village movement" was in

\footnotetext{
${ }^{33}$ Ibid. , p. 11 .

${ }^{34}$ Ibid., p. 14 .
} 
full stride when it was unexpectedly stimulated by the general strike of 1842 .

Both migration to the villages and the formation of coastal settlements benefitted directly from the strike. with the sugar industry in chaos, land values declined significantly, reversing the inflationary prices paid for estates often a few months earlier. Some laborers were able to purchase land at bargain-basement prices. Plantation Plaisance, five miles from Georgetown on the east coast of Demerara, was sold for $\$ 39,000$ with all buildings and a couple of mules. A year earlier, Plantation Friendship, an estate that was abandoned but sightly larger than Plaisance, was sold for twice the price. On the east bank of Demerara, villages within easy reach of Georgetown were commenced at Farm, Garden of Eden, and Peter's Hall. In Berbice, Plantation Enfield was sold for $\$ 10,000$, although a decade earlier it had been worth $\$ 145,000 ;$ and Plantation Port Mourant was sold for $\$ 35,000$, although it had been assessed at $\$ 175,000$ during the apprenticeship period. The county of Essequibo witnessed the emergence of the villages of Danielstown and Bush Lot, and the trebling of the population of the village of Queenstown. ${ }^{35}$ By the end of 1842 , over 15,000 acres of plantation had been purchased for more than a quarter of a million dollars. An estimated

\footnotetext{
${ }^{35}$ Ibid. , pp. 17-18
} 
16,000 African-Guyanese were now residing in villages formed in the post-emancipation era. ${ }^{36}$

Mimicking the events of 1842 , the strike of 1847 was followed by increased migration from the plantations to the villages. More than 10,000 laborers abandoned the estates for villages. The village population now amounted to 44,456 persons, whilst only 19,939 African-Guyanese remained on the sugar plantations. ${ }^{37}$ Land values declined precipitously, and this led to increased purchases. For example, in November 1848, Plantation Great Diamond was sold for $\$ 9,000$, although it had recently been valued at $\$ 150,000 .{ }^{38}$ Between June 1847 and December 1848, the population growth in some of the established villages was quite remarkable. The population of Victoria increased from 827 to 2,370 ; Plaisance, from 131 to 1,372 ; and Queenstown, from 148 to 877. ${ }^{39}$ Before 1838, there were only three villages on the Guyana coast: Mahaicony, Mahaica, and Aberdeen. By 1848, over 100 villages were strewn along this low-lying plantation belt. Twenty-five communal villages consisting of 9,049 acres had been purchased for $\$ 400,000 ; 7,000$ persons were in possession of 6,413 acres of land worth $\$ 631,000$ in the proprietary villages; and 13 settlements

\footnotetext{
${ }^{36}$ Clementi 1937, op. cit., p. 280.

${ }^{37}$ Young 1958, op. cit., p. 23.

${ }^{38}$ Ibid. , p. 21 .

${ }^{39}$ Ibid.
} 
bought for $\$ 7,000$ were to be found on crown Lands. The number of houses in the villages stood at 10,544, with an estimated construction cost of one million dollars and another half million dollars spent on land improvements. Therefore, between 1838 and 1848, African-Guyanese had spent two-and-a-half million dollars on the purchase of land, housing, and improvements, in what can only be considered a determined effort to gain their economic independence from the sugar planters.

Pressured by the plantocracy and the colonial Government through political and legal maneuvers and discriminatory taxation policies, the village movement, which had reached its zenith only in 1848, was already beginning to decline in 1851. Villagers had exhausted all their savings on the purchase of land, the construction of houses, and in a few cases machinery. In the early years of the post-emancipation era, laborers had paid as much as $\$ 240$ an acre for estates, but this exorbitant purchase price had declined to less than $\$ 10$ an acre by 1850. Consequently, villagers had little or no working capital left to maintain estates that required significant expenditure outlays for the maintenance of drainage, irrigation, and sea defense facilities.

Successful peasant agriculture on the Guyanese coast required a combined and concerted effort to regulate the elaborate system of dams, sea defenses, sluices, and 
drainage canals which controlled the flow of water on the plantations. The villagers simply did not possess the organizational ability, the technical skills, nor the financial resources to cope with the overhead facilities required to undertake this task. And since no individual peasant proprietor could cultivate his plot unless the whole estate's infrastructure was in working order, the villages became little more than "pestiferous swamps". ${ }^{40}$ Houses were inundated by water, and the roads and dams became so impassable that in 1850 the mail from Georgetown to New Amsterdam was often delayed. ${ }^{41}$ Sometimes the only means of getting about a village was by boats or corials. Every member of a village was obliged to keep the channels of the main drainage system, as well as his own piece of land, free from mud and other obstructions, but few were so inclined. In some cases, white plantation owners who had control of drainage and irrigation facilities used them to swamp adjacent villages. ${ }^{42}$

The horrid state of the villages was further compounded by the tendency towards land fragmentation, which under the existing Roman-Dutch law mandated the distribution

\footnotetext{
${ }^{40}$ Rodway and Stark 1895, op. cit., p. 48.
}

${ }^{41}$ Rodway 1912 , op. cit., p. 175.

${ }^{42}$ Danns, G. and L. Matthews. 1989. Perspectives on the Development and Underdevelopment of Communities in Guyana: A Sociohistorical Analysis. In M. Martin and T. Kandal (eds.), studies of Development and Change in the Modern World. New York: Oxford University Press, p. 181. 
of holdings amongst the heirs of the deceased proprietors, unless they were specifically barred by some prematrimonial settlement. Fragmentation militated against large-scale production, and rendered impossible a viable subsistence economy. Fragmentation further served to complicate cooperative endeavors, by increasing the number of vested interests in a village, and thus its organizational ability to deal with village matters.

Related to the fragmentation of holdings was the problem of titles to village lands. Communal villages had been bought as single units, with titles being vested in one or a few selected proprietors on behalf of all the shareholders. This system of purchasing cooperatively soon disintegrated with exposure to the dominant individualist capitalist ideology of the times. Instead of owning lands in common, shareholders sought to secure titles in severality. This led to frequent disputes, since cadastral surveys had not been made in many cases. Proprietors had simply agreed on individual boundaries in demarcating their parcels of land. Oftentimes land was distributed to individuals throughout the estate, to ensure some degree of equality with respect to fertility and other locational benefits. The result was not only greater fragmentation, but substantial difficulties in ascertaining title, and hence security of tenure. 
Villages were also saddled with the burden of maintaining the public road and bridges which ran through their villages. Unlike the maintenance of drainage and other infrastructural works discussed previously, the maintenance of the public road, formerly the responsibility of the European plantation owner, was now a legal obligation of the villagers. Failure to keep up the road not only resulted in personal inconvenience, but under the law it could result in the loss of the village itself. With a view toward collecting the necessary funds to repair the road and bridges, the Court of Policy passed a number of ordinances to remedy the situation. For instance, ordinance No. 10 of 1849 authorized the commissioners of the village of Queenstown, Essequibo, to levy a rate of 2 percent on the value of all lots and buildings in the village, to meet the cost of road maintenance.

The villagers rallied against the new rates. Many saw them as the final straw in the dissolution of the village movement. For whilst the villages were asked to meet the full costs of public works through the rates on property, the Colonial Government was subsidizing the planters by financing up to one-third of the costs of immigration. A solution to the infrastructural problems of the villages would have been to charge the general revenues of the country with the maintenance of the requisite services. This, of course, would have increased public expenditure, 
and also would have shifted the burden from the villager to the plantocracy. This scenario, could not be played out in the planter-dominated Combined court, whose members insisted on the levying of local rates. Maintaining control and improving its own position were the guiding principles of planter policy. Emphasis was placed on those reforms considered most beneficial for the plantocracy. Thus, items not related to planting concerns were given scant attention.

In 1851, the unequal and discriminatory nature of Guyanese society was blatantly apparent. At a time when planters were benefiting from subsidized immigration, Georgetown was receiving additional dollars from the public purse through various license arrangements, the villages and the fledgling African-Guyanese peasantry were expected to be self-supporting. In the face of major structural features impeding village development, and enhancing rural unemployment and underemployment, villagers were pushed to the urban centers in search of work. Those who remained became semidependent on the plantations, with only a minority remaining an independent peasantry.

\section{Immigration}

Attempts to solve the colony's labor problem also produced totally new migrants, new to the colony and from new parts of the world. Another strategy pursued by the plantocracy after emancipation was the quest for an alternative labor force through indentured immigration. 
Indentured labor was certainly not new to the caribbean; other colonies had sought to acquire European bondservants for agricultural labor from the sixteenth century onwards. Proving unsatisfactory and unreliable, European forced labor was abandoned in favor of African slaves. Even before August 1, 1838, the planters had sought to introduce a malleable labor force into Guyana. Blinkered by centuries of coercive labor practices, planters simply could not conceive of a free labor market. During the apprenticeship period (1834-38), they had already introduced laborers from Africa, the West Indies, Madeira, and India. However, the emancipation of 1838 , the consequent development of the village movement, and migration to the two urban areas only served to magnify the acuteness of the labor problem. It was widely felt that Africans should be prepared to work cheaply, steadily, and consistently, whenever their labor was wanted and for as long as it was wanted. According to this point of view, both the migrants to Georgetown and New Amsterdam and the peasantry had betrayed the planters in their abandonment of the sugar estates. Salvation of Guyana's economy, therefore, required imports of labor from abroad to cultivate what remained of the plantations. The planters turned to India for what they hoped would be a cheaper and more reliable labor source. 
The system of indentured labor pursued by the planters, although arguably legally defensible, was to all intents and purposes a "new system of slavery." According to Ruhoman:

No trick of sophistry or twist of logic; no adornment of rhetoric or contrivance of art; can ever avail to defend, successfully, the system of semi-slavery, paraded under the guise of indentured immigration, under which Indians were brought to the colony to labour on the sugar plantations, in the interests of a powerful and privileged body of capitalists. ${ }^{43}$

Laborers were brought on contracts or bonds signed in British India. Drought and famine produced a large labor market throughout the Indian ocean region.

The planters were successful however in convincing the British Government that immigration was necessary, by establishing that there was an identity of interests between them and the public. The colony's very foundation was said to be dependent on the sugar industry. Even the ex-slaves, they argued, who were migrating to the villages would prosper as the sugar industry prospered.

Indentured immigration was not without its critics in the metropole. Abolitionists charged that the treatment meted out to indentured immigrants was both brutal and unjust. John Scoble, the secretary of the Anti-slavery Society, on a fact-finding tour in Guyana in 1839, found ample evidence of cruelty. Contrary to their contracts,

${ }^{43}$ Ruhoman, P. 1947. Centenary History of the East Indians in British Guiana, 1838-1938. Georgetown: Daily Chronicle, p. 118 . 
laborers were often flogged, and on one plantation it was alleged that salt was applied to the wounds.44 Evidence was also unearthed that many of the laborers were tricked or coerced into coming to Guyana. This was exemplified by a report in which a group of about 20 indentured laborers were found trying to cut their way eastward, through the bush, in the hope of reaching Bengal! ${ }^{45}$ Mortality amongst the group was particularly high; of the initial batch of 396 who had arrived in May 1838,64 had died by September $1839 .^{46}$ Furthermore, abolitionists argued that the immigrants were providing unfair competition for free African workers by depressing wages.

The furor over Indian immigration led to its suspension in July $\mid 1838$, and prohibition during the fall of 1838.47 The planters were now faced with a catastrophic situation, at a time when African-Guyanese were leaving the plantations en masse and sugar production had declined by a third. They desperately wanted public aid to subsidize their immigration enterprises, and in 1839 the court of Policy passed an ordinance granting a loan of 400,000 pounds for the purpose of introducing immigrants into the colony.

${ }^{44}$ Scoble, J. 1840. Hill Coolies in British Guiana and Mauritius. London, p. 16.

${ }^{45}$ Ibid. , p. 20 .

${ }^{46}$ Nath 1970, op. Cit., pp. 22-23.

${ }^{47}$ Nath 1970, op. cit., pp. 22-23. 
The ordinance was opposed by the governor, and when it reached the Colonial office it was disallowed. The British Government did not disagree with the idea of enlarging or supplementing the labor supply; however, it was unsure whether public revenue should be used to finance planters in Guyana.

If the capitalists are anxious to enlarge their agricultural and manufacturing operations, it seems reasonable that the expense should be borne by themselves, and that funds to which every member of society is a contributor should not, for this purpose, be diverted from their more legitimate destination. ${ }^{48}$

Undaunted by the rejection, the planters petitioned the Queen to authorize the loan and to lift the embargo on Indian immigration. However, Lord John Russell, who had replaced Normandy as the Secretary of state for the Colonies, also rejected the request:

I confess I should be unwilling to adopt any measure to favour the transfer of labourers from British India to Guiana, after the failure of the former experiment. Admitting that the mortality of the Hill coolies first sent may have been accidental, I am not prepared to encounter the responsibility of a measure which may lead to a loss of life on the one hand, or, on the other, to a new system of slavery. ${ }^{49}$

A few enterprising planters had anticipated the Colonial Government's decision and had established a Voluntary Subscription Immigration Society in December of 1839, through which subscribers were to be allotted

\footnotetext{
${ }^{48}$ Official Despatch, Normandy to Light, Aug. 15, 1839.

${ }^{49}$ Official Despatch, Russell to Light, Feb. 15, 1840.
} 
immigrants in proportion to their investment. The undertaking proved to be a financial disaster. Nevertheless, between April 1840 and February 1841, the society did succeed in introducing into Guyana about 2,900 freed African laborers from Barbados, and about 70 AfricanAmericans from Baltimore, Maryland, in the United states. Most of the immigrants from Baltimore returned home, whilst the Barbadians were left to drift into the villages and the towns. 50

Smarting from the Home Government's decision to disallow the immigration loan ordinance, the plantocracy sought to utilize their control of the combined court by refusing to pass the civil List from which government official salaries were paid, unless they could be guaranteed loans for unfettered immigration. Faced with a stoppage of supplies, the British Government appointed Sir Henry Macleod, the Governor of the neighboring colony of Trinidad, to arbitrate in the matter. Macleod quickly adjudicated a settlement and on January 7, 1841, a Civil List was passed for seven years. In return, the combined court was allowed to pass an ordinance on January 18,1841 , in which surplus revenue was to be used to finance the importation of immigrants. ${ }^{51}$ During 1841 a total of 8,144 immigrants were

${ }^{50}$ Rodway 1894, op. cit., vol. III, pp. 100-102; Webber 1931, op. cit., Appendix, P. xvi.

slclementi 1937, op. cit., p. 115. 
introduced - 4,297 Portuguese from Madeira, 2,745 from the West Indies, and 1,102 from Africa. No Indians arrived, since immigration from that country was still prohibited. Mortality among the Portuguese was extremely high, partly owing to an epidemic which decimated their numbers in 1841. As a result, immigration from this source was suspended in May 1842. Bounty-aided immigration from the West Indies had already been terminated in october 1841, following complaints of poaching by West Indian planters. Not for the first time, the Guyanese planters were faced with what they considered to be an intolerable situation. To illustrate their case, they pointed to the immigration figures, which had declined to 2,767 persons in 1842 . Planting interests in the combined court took up the fight and threatened once again to hold up the civil List. The British Government, unwilling to invoke an Act of Parliament in order to curtail the powers of the combined court, capitulated to the plantocracy. Pressure was brought to bear on the Indian Government to rescind the prohibition on immigration, and by November 1844 emigration to Guyana was reopened. At the same time the Combined Court was authorized to raise a loan of 500,000 pounds for immigration purposes. The success of the planters was now complete. The village movement, emancipation, and restrictive immigration laws had greatly threatened their stranglehold on Guyana's economy; but with ample recourse to immigration, 
they had succeeded in circumventing the uncertainties of a free labor market and had reasserted their economic hegemony.

Following the policy reversals by the Indian and British Governments, 816 Indians arrived in Guyana in 1845 . Large-scale immigration was now in full swing, and under the auspices of the government. Between 1846 and $1848,24,848$ indentured laborers were brought into the country, of whom 11,025 came from India, 10,036 from Madeira, 3,359 from Africa, and 428 from the West Indies.

After a temporary suspension during 1849-50, Indian immigration was reopened in 1851. This was particularly important to the sugar industry, for it resulted in tremendous gains in the production and export of sugar and its by-products. Between 1838 and 1917, when the indentured system was terminated, 238,960 Indians were introduced into Guyana (Table IX). Indian immigration far overshadowed all other immigrant groups in the post-emancipation era. Chinese immigration was inaugurated in 1853 when 647 immigrants arrived in the colony, but the difficulty of obtaining an adequate supply meant that immigration of this group was rather sporadic. Their numbers were never very high, and by the time they stopped coming to Guyana in an organized fashion in 1878, only 13,534 had arrived. Portuguese immigration commenced in 1835 with a batch of 429 laborers, and ended in 1882, at which time 31,628 persons 
were brought to Guyana. By the time the indentured system ended in 1917, these three groups were augmented by a total of 40,883 West Indians and 13,355 Africans.

TABLE IX

GUYANESE INDENTURED IMMIGRATION 1835-1917

origin
India
China
Madeira, Azores,
Cape Verde
West Indies
Africa
England
Malta
USA

\section{Number}

238,960

14,189

31,628

40,883

13,355

$$
21
$$$$
208
$$

70

\section{Dates}

$1838-1917$

1853-1912

$1835-1882$

$1835-1917$

$1838-1865$

1851

1839

1840

\footnotetext{
Total

339,314

Sources: Webber 1931, p. XVI;

Nath 1970, pp. 219-220.

Note: Although Indian indentured immigration

ceased in 1917, 607 Indians returned from India

during the 1920 s to become free settlers in

Guyana. An additional 1,729 West Indians also

arrived in the country during this period.

Therefore, between 1835 and 1928 a total of

341,650 recorded contract immigrants from all

corners of the globe arrived in Guyana.
}

Throughout the 1884 depression, planters never ceased their strident calls for immigration. Although the rate of immigration declined after $1884,5,779$ immigrants arrived in 1891. 52 State-aided immigration of the Portuguese had ceased in 1882, and that from the West Indies had ended in 1886; therefore, all immigrant:s were now coming from the

\footnotetext{
${ }^{52}$ Nath 1970, op. cit., p. 220.
} 
Indian sub-continent. In 1886, expenditure on immigration was costing the colony $\$ 236,897$; the cost of return passages alone was $\$ 123,000.53$

The sugar industry was once again flourishing during World War I, but in the midst of its rediscovered glory, the plantocracy was confronted with a new crisis. The Indian government, pressured by public opinion at home, abolished the system of indenture in 1917. The government's indictment of the system was on two counts. Firstly, the recruitment system was deemed to be inequitable since Indians were bound to go to a distant land where they were prevented from choosing an employer of their choice, were paid a wage less than that of a free person, were tied to an employer for five years, and had to live on the estates under very restrictive circumstances. Secondly, the government concluded that conditions in the colony were not conducive for the well-being of immigrants, and this was evidenced by the large numbers of prosecutions brought against them, their high mortality rates, high rates of suicide, and immorality on the estates. ${ }^{54}$

${ }^{53}$ Webber 1931, op. cit., p. 296.

${ }^{54}$ Official Despatch from secretary of state for the Colonies on the Subject of the Total Abolition of Indentured Immigration from India, M.C.C., 1916. 
DEMOGRAPHY

Utilizing census data from 1851 to 1911, this section examines the country's demographic structure, particularly as it relates to Georgetown and New Amsterdam.

The Census of 1851 , the first for which records are readily available, enumerated a total population of 135,994 , or an increase of 37,840 from the figure for 1841 (Table X).$^{55}$ The increase, however, must be attributed to immigration, since during the intercensal period 43,314 persons, mostly Indians, and a fair number of Portuguese, arrived in the colony. In 1841 the immigrant population was only 14,328, or 14 percent of the population, but with their increased numbers they had begun to irretrievably alter Guyana's demographic as well as its spatial, political, economic, and social structure.

\section{TABLE X}

RACIAL COMPOSITION OF THE POPULATION 1851

Race Guyana $\%$ Georgetown $\cong$ N/Amsterdam

\begin{tabular}{lrrccrc} 
Indian & 7,682 & 5.6 & 871 & 3.4 & 153 & 3.3 \\
African/Colored & 108,428 & 79.7 & 20,907 & 82.0 & 3,978 & 85.9 \\
White & 3,630 & 2.7 & 3,730 & 14.6 & 499 & 10.8 \\
Portuguese & 7,928 & 5.8 & - & - & - & - \\
Amerindians & 7,000 & 5.1 & - & - & 3 & - \\
Other & 1,316 & 0.1 & - & - & - & - \\
\multicolumn{1}{r}{ Total } & 135,994 & $99.0 *$ & 25,508 & 100.0 & 4,633 & 100.0
\end{tabular}

Source: Census 1851.

* Rounding accounts for deviations from 100 percent.

${ }^{55}$ Census 1851. 
In 1851, Georgetown boasted a population of 25,508 , or 18.8 percent of the country's population (Table XI).${ }^{56}$ Its population had more than doubled since 1831, with much of the growth stemming directly from the abolition of slavery. The success of the village movement had deflected many potential migrants to the urban areas.

TABLE XI

POPULATION DISTRIBUTION 1851-1911

Year Guyana Georgetown $\%$ N/Amsterdam $\div$ Urban

$\begin{array}{llllllll}1851 & 135,994 & 25,508 & 18.8 & 4,633 & 3.4 & 30,141 & 22.2 \\ 1861 & 155,907 & 29,174 & 18.7 & 4,579 & 2.9 & 33,753 & 21.6 \\ 1871 & 193,491 & 36,562 & 18.9 & 5,437 & 2.8 & 41,999 & 21.7 \\ 1881 & 252,186 & 47,175 & 18.7 & 8,124 & 3.2 & 55,299 & 21.9 \\ 1891 & 278,328 & 53,176 & 19.1 & 8,903 & 3.2 & 62,079 & 22.3 \\ 1911 & 296,041 & 57,577 & 19.4 & 8,604 & 2.9 & 66,181 & 22.3\end{array}$

Sources: Census 1851-1911.

Schomburgk estimated the population of Georgetown at 23,000 as early as 1843.57 After that time the town's growth was far from spectacular. Most of the growth which occurred was concentrated within the city proper, but there were also some noticeable developments in the suburbs. ${ }^{58}$ The suburbs of Freeburg and Newburg, Albertown, and Lodge

\section{${ }^{56}$ Ibid.}

${ }^{57}$ Schomburgk, Richard. 1847. Travels in British Guiana 1840-1844. Tr. W.E. Roth, 1922. Georgetown: Daily Chronicle, p. 32 .

${ }^{58}$ In 1842 Letters Patent were issued by Queen Victoria ordaining Georgetown a city. 
contained 3,793 inhabitants, or nearly 15 percent of the city's population. These three settlements were overwhelmingly peopled by African-Guyanese (83 percent), who had sought to build outside the wards, so as to take advantage of lower land prices, lower taxes, and lessstringent building regulations. Indeed, Georgetown as a whole was predominantly African-Guyanese in 1851. Some 55 percent of its population was African-Guyanese, 27 percent mixed, ${ }^{59} 15$ percent white, and 3 percent Indian. There were no permanent Amerindian residents to be found in the city. ${ }^{60}$ When Schomburgk visited Georgetown in the early 1840s, he observed that the "natives" were only very rarely seen in the town. Perhaps their aversion to the place was partly due to the deep schism that had developed between them and the African-Guyanese population. Their role as slave-police during slavery days had not been forgotten in a society where stereotypes predominated the racial divide. According to Schomburgk:

When such parties of Indians are noticed in the city, the negroes do not let them out of their sight but follow them like jackals or vultures after a caravan in the desert, and as soon as the vast quantity of liquor imbibed begins to take effect, get hold of the remaining money or "trade" already bought, either by fair means or foul. ${ }^{61}$

${ }^{59}$ This group is most often identified with the AfricanGuyanese population.

${ }^{60}$ Census 1851.

${ }^{61}$ Schomburgk 1847, op. cit., p. 61. 
In addition, their services were no longer required by the white ruling class.

Before Emancipation, when the Colony still particularly required the services of the Indians, the authorities kept a large house or caravanserie for them in the west end of the town, where they could always find a camp on their temporary visits. Now that their help is no longer required these quarters have been allowed to go to ruin. ${ }^{62}$

The white population for the most part were composed of the English. English merchants were predominant on Water Street, the commercial center of the city, where their storehouses and wharves were accessible to the Demerara River. Europeans resided mainly in Columbia and Lacytown, North and South Cummingsburg, Kingston, Robbstown, and Stabroek. The African and mixed populations were scattered throughout the wards, but the highest number $(3,305)$ were to be found in Columbia and Lacytown. There were only 871 Indians in the city, and they were concentrated for the most part in the wards of Stabroek and North Cummingsburg. ${ }^{63}$ The overall Indian population in Guyana numbered 7,682. No Indian immigrants arrived in the colony during 1849 and 1850. Those who were already in the country had begun to leave the estates even before their contracts had expired. Ill treatment and high mortality on the estates convinced the Indians to head for the urban centers where social services were more available. Failing to find

\footnotetext{
${ }^{62}$ Ibid.

${ }^{63}$ Census 1851 .
} 
remunerative employment, many became vagrants, wandering about the streets "or picking up refuse from the gutter". ${ }^{64}$ others simply died of want. Another possible reason for the Indian immigrants leaving the estates was their observation that patients treated in Georgetown's public hospital had a far greater chance for recovery than those who opted for treatment on the estates. ${ }^{65}$ The public hospital had been built in 1843, as a result of a vote of 205,000 guilders from the Combined Court. ${ }^{66}$ In addition, the urban areas possessed more medical practitioners per population than the rural areas where the immigrant was confined. Georgetown boasted one doctor for every 2,319 persons; New Amsterdam, one for every 1,158; and the countryside, one for every $4,409.67$

Hoping to restrict the Indians to the estates, the plantocracy promulgated laws which prohibited an immigrant from travelling more than two miles away from his or her plantation without a pass. The power to arrest miscreants was not limited to the police, but was also vested to managers and overseers of the estates. As a further precaution to prevent immigrants from entering Georgetown,

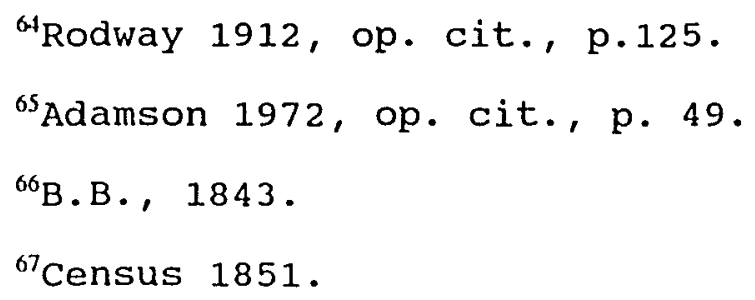


pickets ${ }^{68}$ were strategically located at Vreeden Hoop and the La Penitence Bridge at the outskirts of the city. Immigrants with legitimate business in the city, including those who were attempting to see their legal protector, the Immigration Agent-General, were oftentimes arrested and charged. ${ }^{69}$

Portuguese immigrants were also moving off the plantations, but their journey to the urban centers were much different from those of the Indians. Portuguese laborers were assisted by the Colonial Government, wholesale merchants, and somewhat surprisingly, by the planters in their efforts to withdraw from the plantations. The white ruling class saw them as an integral component in the continuation of white dominance, and as a means of stifling the development of other racial groups. Portuguese immigration peaked in 1846 when 5,975 laborers were brought into Guyana. Rodway expressed the belief that the Portugulese received preferential treatment in order "to drive the negroes into the fields."70 By the mid 1840s, wholesale merchants in Georgetown and New Amsterdam had withdrawn the credits they had previously offered the African-Guyanese and colored population, and had in turn extended them to the Portuguese, who rapidly utilized their

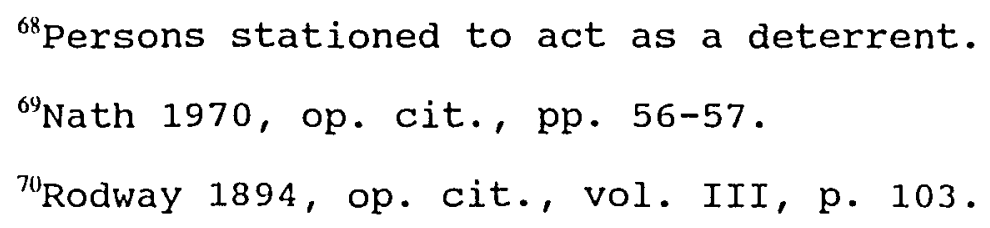


newfound resources to oust the Afro-Guyanese from the retail and huckster trade. The English merchants, however, were careful to retain for themselves the colony's wholesale trade. Consequently, Portuguese businessmen were absent along water street, although in 1851 they owned 173 (58 percent) of the licensed retail shops in Georgetown. ${ }^{71}$ For the country as a whole, the Portuguese petty merchant class held 484 (62 percent) of the retail shops. In New Amsterdam the figure was 28 (54 percent), and in the rural areas 283 (65 percent).$^{72}$

There were nearly 500 merchants and shopkeepers in Georgetown. One hundred and ninety-six, or 64 percent, of the country's "public officers" were residents here. "Mechanics and artizans," that is, those in the skilled trades, numbered 2,063 persons. However, the bulk of the city's population were classified as general laborers or "variously employed." An interesting feature of the labor force was the sizeable number $(2,467)$ who were defined as making a living as "agricultural laborers."73 Estates along the East Coast and West Bank Demerara were the main beneficiaries of this labor. That over 14 percent of the capital's active labor force was engaged in agriculture was

\footnotetext{
${ }^{71}$ Census 1851 .

${ }^{72}$ Ibid.

${ }^{73}$ Ibid.
} 
clearly a reflection of the dominance of that industry in the country's economic structure.

New Amsterdam, in contrast, did not experience the same kind of population surge during the 1831-1851 period, although its population increased a healthy 60 percent, from 2,800 to 4,633 . Within the town, just over 50 percent of the population were African-Guyanese, 35 percent mixed, 11 percent white, and 3 percent Indian. Merchants and shopkeepers numbered 84, public officers 17, and skilled workers $417 ;$ and whilst there were 306 agricultural laborers, they accounted for only 11 percent of the town's active labor force. The largest segment of the economically active population, 645 persons, were employed as domestic servants, a clear indication that there were very few productive jobs available in the town. ${ }^{74}$

According to the 1851 census figures, just over one in five Guyanese were living in the urban areas (Table XI). Since 1831 the rate of urbanization had been increasing, but most of that increase must be attributed to the capital city. Dependent urbanism was most notably characterized by uneven urbanization, with the result that Georgetown had become five-and-a-half times the size of New Amsterdam and was plainly outdistancing its rival. Hardly any shipping frequented New Amsterdam's port. Most of the produce was sent to Georgetown for shipment to the United Kingdom.

\footnotetext{
${ }^{74}$ Ibid.
} 
Colonialism merely required Georgetown, and its functional port, to serve as the economic intermediary between the metropole and the colony.

The population of Georgetown, according to the Census of 1861 , was 29,174 , which represented an increase of 3,666 , or 13.6 percent over the 1851 figure (Table XI). Whilst the growth in population was rather meager, it overshadowed the plight of New Amsterdam, which registered a decline of 54 persons. For the country as a whole, the total population amounted to 155,907 , an increase of 19,913 , or 13.8 percent over the previous decennium. The increase was particularly anemic when one considers that 39,207 immigrants were brought into the country over the period. The majority, 23,381, came from India, with Chinese immigration having peaked at a relatively modest level in 1861 when 3,368 laborers entered the colony. Given the fact that 4,040 immigrants were repatriated, the mortality rate during the period must have been quite considerable. A yellow fever epidemic swept across the colony from 1851 to 1853 , and this was followed by outbreaks of smallpox in 1855 and cholera in 1856.

By 1861 Georgetown was six times the size of New Amsterdam. Its port cleared 773 vessels during this year, whilst its rival cleared a modest 62 . The decline in the level of urbanization during the decennium was matched by a moribund urban economy that was dependent on capital 
infusions from the public sector. In Georgetown, domestic servants comprised the largest occupation group, accounting for almost 25 percent of the employed population. Their numbers had almost doubled, from 2,067 in 1851 to 3,892 in 1861. Agricultural laborers had also increased from 2,467 to 3,187 . Workers in Georgetown were therefore largely either supporting themselves in unproductive employment or dependent on a living outside the city. In New Amsterdam, the situation was strikingly similar, although agricultural laborers experienced the most significant growth in numbers. Most of the town's population were still domestic servants (588), but the number of agricultural laborers had risen 59 percent to 517. Unemployment in both urban areas is difficult to ascertain, but there is no doubt that the figures were quite alarming. Children and those classified as having not stated an occupation accounted for 46 percent of Georgetown's population and 47 percent of New Amsterdam's. In 1851, the comparable figures were 33 percent for Georgetown and 43 percent for New Amsterdam. The Chinese, at this time, were beginning to make some inroads in the retail trade, but because of their relatively small numbers they did not pose a threat to the dominant Portuguese. However, by 1865 there were 170 Chinese-owned shops in Georgetown alone, and many more in the rural areas. ${ }^{75}$ At the same time the portuguese were beginning to

\footnotetext{
${ }^{75}$ B. B. , 1865 .
} 
challenge the English wholesale merchants in Georgetown. A number had already bought property on water street, which was once the exclusive preserve of the English. ${ }^{76}$

The decennial census of 1871 revealed a population of 193,491 (Table XI). The net increase was 37,584 over the 1861 population, but during the decade 61,924 immigrants had arrived in the country. Since only 7,000 persons were repatriated to their countries of origin, one must conclude that mortality was once again very high, and that the natural increase was negative. Yellow fever raged continuously in the colony from 1861-66, and was the major killer during the period.

The population of Georgetown in 1871 numbered 36,562 , and though the city's population growth was rather modest, it was now nearly seven times the size of New Amsterdam. The occupational structure of both urban areas suggests that their economical problems had not abated. Forty-two percent $(15,378)$ of Georgetown's population were without work. Those who were lucky enough to be gainfully employed were confined to four principal occupational groupings including agricultural laborers $(4,317)$, domestic servants $(3,667)$, mechanics and artisans $(3,377)$, and a catch-all category variously employed $(6,968)$. The situation in New Amsterdam was roughly analogous to that of the capital city. Fortytwo percent of the town's people were unemployed, and those

\footnotetext{
${ }^{76}$ Webber 1931 , op. cit., p. 258.
} 
who were working were predominantly in the same occupations - agricultural laborers (793), domestic servants (573), mechanics and artisans (541), and variously employed (787) .

overall, the rate of urbanization was negligible. Rural areas were absorbing the influx of indentured immigrants, which had peaked amongst the Indians in 1869, when 7,168 workers arrived in the country. Since all indentured workers went to the estates, some of these estates were quite large. In 1871 plantation Leonora, the largest estate in the country, boasted a population of 1,442. Indeed, according to the census, 67,859 persons, or 35.1 percent of the population, were residing on the sugar plantations. The remainder, 83,633 persons, or 43.2 percent of the population, were inhabitants of the villages and settlements. Plaisance, on the east coast of Demerara, was the largest village, with a population of 3,169 .

A notable aspect of the population distribution in 1871 was the nascent out-migration of Indians from the estates to the urban areas, and especially to the villages and settlements. There were 1,148 Indians in the two urban areas and over 2,500 in the villages and settlements. Since it is unlikely that these numbers are the result of natural increase, one must conclude that some degree of in-migration was taking place amongst the groups. In accounting for the migration, one needs to be cognizant of the dynamics that 
shaped the process. Conditions on the estates were deplorable. The hours were long and the work arduous. The legislature had unilaterally devised a series of labor laws so strenuous that the immigrant had little alternative but to break them. The labor laws were consolidated in Ordinance No. 4 of 1864 , which contained provisions that allowed employers to press criminal charges against workers who did not accomplish a set number of tasks in a week, those who failed to attend morning muster-call or were absent from work, and those who refused or neglected work. Planters had managed to introduce criminal sanctions for matters that were essentially civil in character. Furthermore, they did not hesitate to use the law as a weapon to coerce the immigrants. Between 1866 and 1870, planters brought 31,900 cases to the courts for breaches of the labor law. The unequal nature of the law is also evident when one considers that during the same period fewer than 100 cases were brought by immigrants against employers. For example, in 1870 about 57 percent of the charges brought against immigrants were withdrawn. ${ }^{n}$ And whilst the immigrant could be sent to jail, the penalties against employers - and these were rarely enforced - were overwhelmingly monetary. Oftentimes employers utilized the labor laws to threaten to reindenture immigrants and thereby elicit promises of good behavior, etc. Managers commonly

\footnotetext{
${ }^{77}$ Des Voeux 1871, op. cit., p. 50 .
} 
boasted that indentured workers on their estates must be actually at work, or in the hospital, or in the gaol. ${ }^{78}$ Planters were operating a most repressive state. Expenditure on the police force had escalated from 20,924 pounds in 1851 to 51,142 pounds in 1871. By comparison, expenditure on education had registered a decline during the same period, falling from 3,212 pounds to 2,610 pounds. ${ }^{79}$ At this time the plantation was, for all intents and purposes, a "total institution" which encompassed all aspects of the immigrant's life. Edward Jenkins offers the following contemporary observation:

Take a large factory in Marchester or Birmingham, or Belfast, build a wall around it, shut in its work-people from all intercourse save at rare intervals with the outside world, keep them in absolute heathen ignorance, and get all the work you can out of them, treat them not unkindly leave their social habits and relationships to themselves as matters not concerning you who make money from their labour, and you would have constituted a little community resembling in no small degree a sugar estate in British Guiana. ${ }^{80}$

Living conditions on the estates were also far from satisfactory. Housing in the barracks-like-blocks was squalid, dilapidated, and overcrowded. Water, sewerage, and sanitation facilities left a great deal to be desired, and as a result mortality on the estates was severe. According

\footnotetext{
${ }^{78}$ Nath 1970, op. cit., p. 41.

${ }^{79} \mathrm{~B} . \mathrm{B} .1851$ and 1871 .

${ }^{80}$ Jenkins, E. 1871. The Coolie, His Rights and Wrongs.
} London, p. 63 . 
to Adamson, the death rate per thousand immigrants resident on the estates was as high as 44.8 between 1855 and 1872 , but subsequently declined to 27.8 between 1873 and 1884 , after the Des Voeux Commission lobbied for better conditions on the estates. ${ }^{81}$ Each estate had been required by law to have a hospital on its grounds, but since facilities were antiquated and doctors were beholden to the estates, the system did not function to the immigrants' benefit.

Given the above, there was every reason for immigrants to leave the estates; however, most importantly, by 1870 the sugar industry had solved its labor problem, and for the first time in the post-emancipation era it experienced a labor surplus.

The Census of 1881 confirmed the large-scale spatial redistribution of population that was taking place amongst the Indians (Table XI). The total Indian population was 79,929 , of whom 52,418 were on the estates, 2,588 in Georgetown and New Amsterdam, and 24,923 in the villages, settlements, and farms. The number of Indians in Georgetown and New Amsterdam indicated that not all immigrants were remaining in agriculture, though the move to the urban areas was still minimal.

The total population of Guyana, according to the Census of 1881 , amounted to 252,186 . This was a significant increase over the population in the previous census. The 
population was growing at an average of 3.3 percent per annum; however, much of increase was due to the 73,787 indentured immigrants who had arrived in the colony. Without their arrival, the country would have certainly posted a decline in its population. Once again, the largest majority of immigrants were those from India, although a considerable number were introduced from the west Indies. The peak year for arrivals in the post-emancipation era occurred during 1873-74 when 10,589 immigrants landed. Georgetown's population between 1871 and 1881 had increased by over 20 percent to 47,175 , but now the city was less than six times the size of New Amsterdam. New Amsterdam's population growth during the decade was impressive. The town now registered a population of 8,124 , or a 67 percent increase from the previous census. It is not difficult to explain the transformation of the town's fortunes. Berbice, the county in which New Amsterdam is located, was becoming a chief destination for immigrants, since the sugar estates here were beginning to outperform those in Demerara and Essequibo. Furthermore, indentured workers who had served their time were buying lands along the corentyne coast, and at Adelphi, Cumberland, and elsewhere in the Canje area. Cumberland itself registered a population of 1,131 and was the largest village in Berbice. Indians selected lands in the vicinity of estates, in this case Rose Hall Estate, on which they continued to work while 
they made the transition to peasant farming. As a result, dependency on the plantations was maintained. The formation of these villages neighboring New Amsterdam was giving succor to the town, since it was in an established position to fulfill the role of a higher service and administrative center.

Despite New Amsterdam's growth, the rate of urbanization scarcely increased over the period. The economies of New Amsterdam and Georgetown were not conducive to the kinds of employment generation that were likely to pull migrants into the towns. Nearly one in four $(6,958)$ workers were unemployed in Georgetown. In New Amsterdam only two percent of the labor force were out of work (i.e., those 15 years of age and older) but the vast majority of the employed were in highly unproductive employment. The occupational structures of both towns were relatively unchanged. Agricultural laborers, mechanics and artisans, domestic servants, and those variously employed continued to be the major occupations. In Georgetown, however, the number of agricultural laborers declined by 17 percent to 3,167 , the fall in agricultural employment should not be interpreted as a sign of movement towards a more typical urban employment structure; rather, it was the result of plantation owners' use of fewer indigenous laborers and the fall in the industry's wages. At the same time that the number of agricultural laborers was declining, domestic 
servants increased by 62 percent to 5,916 , and those variously employed increased by 62 percent to 11,304 . In New Amsterdam, all occupational groupings registered advances, but the most significant were the 72 percent increase in the number of public servants to 175 , and the 68 percent rise in the number of merchants and shopkeepers to 163.

According to the Census of 1891, the total population of the country was 278,328 , an increase of 26,142 , or nearly 10 percent of the 1881 figure (Table XI). During the intercensal period, 34,266 immigrants arrived in the colony and 16,849 emigrated, leaving a net immigration figure of 17,417. Since this number is insufficient to cover the population increase over the decennium, we must conclude that for the first time since its incorporation into the modern world system, the colony was experiencing natural increase, that is, the birth rate exceeded the death rate. The increase, however, was only 9,725.

The occupational structure of the country was still dominated by the sugar industry in 1891. Limited avenues of employment resulted in some 105,444 persons being returned as agricultural laborers. In the towns, the number of workers employed in agriculture continued to decline. Domestic servants and those in semi-skilled positions continued to comprise the bulk of the laboring population. 
The population distribution was slightly altered in 1891. There was a marginal increase in urbanization, with 62,079 persons, or 22.3 percent, living in Georgetown and New Amsterdam. Georgetown was unquestionably the center of economic, social, and political life. It accounted for 53,176 , or 19.1 percent, of the population and New Amsterdam 8,903 , or 3.2 percent. In the rural areas there were 90,492 persons, or 32.6 percent, living on the estates, and 125,757 , or 45.1 percent, in the villages and settlements. Villages were still comparatively small and tended to decline in numbers with distance from Georgetown. The largest village was Plaisance, with a population of 4,705, on the east coast of Demerara. The number of Indians residing off the estates and not in the towns had risen from 24,923 in 1881 to 28,412 in 1891 . Although the increase was not of great import, the trend was beginning to accelerate during the latter part of the decade. In the urban areas Indians amounted to 5,238 persons, compared to 2,588 in 1881 .

At the turn of the century, Georgetown was in a pitiful state. There was tremendous concern over the alarming death rate in the town. According to the surgeon General, Georgetown had a death rate of 35.2 , which was over 11 points higher than that of the rest of the country in 1902. In accounting for the appalling rate, he noted that sanitation and sewerage disposal in the city were abysmally 
poor, and that overcrowding was excessive, especially amongst the lower classes. ${ }^{82}$

The Census of 1911 returned a population of 296,041, or an increase of 17,713 over that of the previous census in 1891 (Table XI) ${ }^{83}$ The excess of immigration over emigration during the period was 29,748; therefore, had there been no Indian immigration, the population would have registered a 4.3 percent decrease from the 1891 population. The country's spatial distribution of population remained virtually unchanged, with 22.3 percent of the population in the urban areas and 77.7 percent living in the countryside. Georgetown's share of the colony's population had increased from 19.1 percent to 19.4, and New Amsterdam's had decreased from 3.2 to 2.9 percent. In the rural districts the number of persons residing on the sugar estates registered a decrease of 19,570 , or 21.6 percent, whilst the number of those living in villages and settlements increased by 31,181 , or 20.9 percent. The spatial transformation in the rural areas meant that, for the first time since 1838, the majority of the country's population were living in villages and settlements. Much of the increase in the villages and settlements was occurring on the east coast and corentyne coast of Berbice, where Indians were migrating and taking up lands as rice farmers,

\footnotetext{
${ }^{82}$ Debates of the Combined Court (D.C.C.), 1904.

${ }^{83}$ For financial reasons, no census was taken in 1901.
} 
following the amalgamation and abandonment of estates as well as the favorable inducements for obtaining land. This area's population rose by 11,608 , or 80 percent, which was by far the largest individual increase of any area in the country.

Georgetown's population of 57,577 represented an increase of slightly over 7.6 percent in 20 years. Most of the city's growth took place in the suburban areas of Kitty, which had benefitted from the extension of the seawall, and Albouystown, which rapidly became the sink of the landless and casual laboring population. In both places, the populations had douiled between 1891 and 1911. The population of New Amsterdam, which had reached 8,903 in 1891, declined by 3.4 percent to 8,604 . New Amsterdam and Georgetown were the principal residences of the European, Portuguese, and Chinese populations, and each of the three groups suffered reductions in their numbers, which adversely affected the population growth of the towns in particular. Europeans, who comprised 1.3 percent of the country's population, declined by 13.6 percent; Portuguese, who comprised 3.4 percent of the population, decreased by 17.1 percent; and chinese, who formed .89 percent of the population, fell by nearly 30 percent.

The 1911 census does not provide information regarding the occupational structure in the towns; however, for the population as a whole, the largest employment sector 
remained agriculture with 106,514 persons, or slightly under 40 percent of the population. Within the various occupational groupings, little had changed since the previous census - an indication of the country's economic structure. The only notable shift occurred within the agricultural sector itself. In the "landed proprietors, agriculturalist and cattle farmers" group, there was an increase of 5,090 persons, or 166.3 percent, with much of the increase precipitated by employment in the rice industry.

\section{INFRASTRUCTURE AND URBAN DEVELOPMENT}

This section discusses the volatility of expenditures and infrastructural allocations to the towns during the period. The fluctuations in the towns' fortunes are shown to be overwhelmingly dependent on the national and international economy, and to a lesser extent on the reluctance of planters and their allies in the combined court to provide funding. Assessments are made to identify the beneficiaries of the public purse throughout the country and within the towns. The internal spatial structure, urban expansion, and the regulations governing Georgetown and New Amsterdam are also explored.

Following emancipation on August 1, 1838, many of the former slaves left the plantations, and migrated to Georgetown and New Amsterdam in pursuit of economic and 
social advancement. ${ }^{84}$ Employment opportunities were rather limited in the urban areas, and as a result some migrants were obliged to pursue a number of nefarious activities. Faced with a severe threat to their pampered urban lifestyles, the government almost immediately created a permanent police force, and along with it the first urban institution in the post-emancipation era, a prison in Georgetown, in 1839. However, this newly created AfricanGuyanese urban underclass proved to be resilient to the erstwhile attempts at social control by the privileged white minority.

Migrants who possessed specialist skills (for example, blacksmiths, carpenters, coopers, masons, wheelwrights, etc.) were able to secure employment related to their particular trades. Migrant women, lacking opportunity to acquire vocational skills, were confined to domestic services. Those who had managed to save money during the apprenticeship period were able to buy lots in the towns and to erect houses. Outside Georgetown, the future wards of Albertown, Albouystown, and Lodge were laid out in 1839 . Building activity was initially restricted to Albertown, which was purchased by a handful of ex-slaves from the proprietors of Plantation Thomas.

The economic downturn following complete emancipation resulted in a deterioration of the country's infrastructure.

\footnotetext{
${ }^{84}$ Gazette Aug. 25, 1838 .
} 
The 1850 commission report emphasized the deplorable condition. The public roads and bridges had deteriorated to such a state that communications by land had been severed between New Amsterdam and the Corentyne. owing to the lack of roads, the villages were poorly serviced; and churches and schools, so important to the laboring population, were neglected.

The two urban areas in the country, Georgetown and New Amsterdam, were also in the doldrums. Merchants were complaining that their once-lucrative trade with the estates had virtually ceased to exist. Given the economic difficulties, purchases of imported commodities had steadily declined following full emancipation. In addressing the commissioners of the 1850 report on "the condition and prospects of the colony," Mr. Duncan McDonald, a partner of George Anderson and Co., one of the leading firms in Georgetown, noted:

For some time after the emancipation, up to, I may say 1845, the labouring classes purchased largely of calicoes, muslins, clothing, boots, shoes, hats, and indeed dry goods generally, as also of malt liquor, hams, low priced wines... glassware, furniture, etc. During the period stated they evinced an eagerness for articles of improved comfort, and a desire to appear respectable. In the last three or four years various circumstances have combined to reduce the demand and consumption of articles not of luxury only, but of ordinary comfort. The labourers now usually confine their purchases to the very few and indispensable articles of clothing, and to articles of necessary food. ${ }^{8.5}$

\footnotetext{
${ }^{85}$ Report to His Excellency Henry Barkly 1850, op. cit.
} 
As Georgetown's mercantile trade declined so did the value of property in the town. Houses' and businesses' valuations were 50 percent of what they had been four years earlier. In New Amsterdam, the merchants were in much poorer shape than their counterparts in Georgetown. Many of Berbice's plantations had been abandoned, there was a high incidence of squatting, and the few plantations that remained were not able to keep many merchants solvent in the town. Property values had fallen, but sales could not be effected even for the most nominal of prices. New Amsterdam was still the commercial center of Berbice, but its internal spatial structure consisted of little more than three principal streets. The merchants, and hence commercial activities, were concentrated along the strand, a street which ran parallel to the Berbice River.

Public expenditure on infrastructure in Georgetown and New Amsterdam up to this point had been kept at a bare minimum. In Georgetown, finances for infrastructural and other works were derived solely from a tax on land and buildings, fixed and levied under the provisions of an annual ordinance passed by the court of Policy on a report forwarded by the Mayor and Town council. At times various licenses (cart, hucksters', porters', gunpowder, etc.), fixed and raised by the combined court, were voluntary voted as contributions to aid the town's funds. Between 1839 and 1844 the following contributions were made by the combined 
Court to the Town funds: in 1839, the proceeds of cart and hucksters' licenses; in 1840, the proceeds of cart and hucksters' licenses; in 1841, half of the proceeds of cart and hucksters licenses, plus a special contribution of $\$ 4,895$ for roads and stellings [harbors] was made to the council; in 1842, the proceeds of cart and hucksters' licenses; in 1843, the proceeds of cart, gunpowder, and porters' licenses, plus a special contribution of $\$ 1,050$ for half the cost of repair of three stellings was made; and in 1844, the proceeds of cart, billiard table, gunpowder, hucksters', and public entertainment licenses. ${ }^{86}$ The appropriation of proceeds from the licenses amounted to approximately $\$ 7,000$ annually. During 1845 and 1846 , the minutes of the court of Policy and Combined court reveal that the expenditures of Georgetown had outpaced revenues. At a meeting of the Combined Court on March 22, 1845, a memorial of the Mayor and Town Council was read, declaring:

That your Excellency and Honourable Court will be pleased to recommend the Honourable Court of Policy to place on their estimate the item for retail spirit and liquor, and other Licence Monies raised within this city, in order that the amount of said licenses may be placed under the sole control of the Municipal Corporation for purposes of City expenditure and improvements, etc. ${ }^{87}$

Peter Rose, manager of the Colonial Bank, whose livelihood depended on the planters, moved "that the prayer

${ }^{86}$ B. B. , $1839-1844$.

${ }^{87}$ Minutes of the Combined Court (M.C.C.), March 22, 1845. 
of this petition cannot be granted", and the motion was carried. Thus, the court maintained its sole right of levying and appropriating all taxes in the country except taxes on lots and buildings in Georgetown and New Amsterdam. The court, however, requested that the Town Council should forward an estimate of its expenses for 1845. The measure was complied with, and on March 25, the council laid over an estimate indicating an estimated expenditure of $\$ 71,359$ and an estimated revenue of $\$ 25,823$. After much discussion, the Combined court resolved that an item of $\$ 28,000$ be placed on the estimate in aid of the town funds, to remedy some of the expected shortfall of $\$ 45,536$. The vigorous debate which ensued was summed up by the Royal Gazette, which noted:

There has been some skirmishing between the Mayor and Town Council of Georgetown and the Legislature. The Corporation has been trying hard to gain possession of the Spirit and Liquor Licenses, issued for the city as a concession, not of favour, but right. In this way they have been foiled by the Legislature, who contend there is nothing in the Town Council's charter, of the nature of that description of revenue, whereon a claim of surrender can be fairly based by the council. Some warm debates in both bodies, and some rather high toned petitions have ensued in consequence, which have resulted in the court of Policy maintaining hold of the Licenses, but recommending a public grant to the Town Council for the service of the year out of the public funds to the extent of $\$ 28,000$. Good care, however, has been taken to let their Worships clearly understand that they are to look on this soon as a free gift, emanating from the pure generosity of the superior powers. ${ }^{88}$

\footnotetext{
${ }^{88}$ Royal Gazette, Apr. 3, 1845.
} 
The legislative proceedings of the year 1846 and subsequent years indicate the volatility of annual payments to Georgetown. In 1847 , a sum of $\$ 20,000$ was voted as a grant-in-aid of the town; in 1848 , the amount voted was $\$ 10,000 ;$ and in 1849 , the court of Policy refused to place on the estimates any grant-in-aid of the town funds. No funds were voted in 1850, but in this year an important question arose as to the cost of Georgetown's sea defenses. Up to this time, the sea Dam between Fort Frederick William and the Thomas Lands had been maintained by the Colonial Government, but in 1849, the military authorities refused to shoulder the charge any longer. They contended that the dam was as much a protection to the Kingston ward of Georgetown as it was to its own ordnance property. Since the very existence of Georgetown depended on the security of the sea Dam, the British Government requested that the Town Council pay for its upkeep, and on its refusal appealed to the Combined court, which declined to place the charge on the colonial funds. In February 1850, the Secretary of state informed the legislature that, unless the situation was remedied, the Queen's troops would be removed. The threat, however, failed to impress the planter-dominated court, which sought to ignore the warning.

On April 4, 1851, the Mayor and Town Council of Georgetown renewed their petition to the combined court, requesting their claim to the allocation of the proceeds of 
the carts, hucksters', and shop licenses, and the house and carriage tax in the town. They also requested one-half of the expense of keeping up the public stellings and fire engines, and a sum of $\$ 3,000$ in reimbursement of the cost for keeping up the main road. In reply to this petition, a motion was filed in the court of policy to place on the estimate the sum of $\$ 10,000$, as a grant-in-aid of town funds, but this was defeated. However, it was decided that the town's petition for the horse-and-carriage tax, the cart, hucksters', and shop licenses, should be granted, and that the proceeds of these taxes and licenses should be nanded over to augment the town funds. The proceeds of these licenses were paid over accordingly to the council in 1851 ; they amounted to $\$ 12,900 .{ }^{89}$

Expenditure on public infrastructure in Georgetown received a significant boost in 1855 when the sea broke through the flimsy sea defenses of mud used to protect the area around Kingston. The entire northern area of the city was inundated with water for two days. Immediately the Court of Policy resolved to erect a permanent concrete structure to keep out the sea. The seawall was commenced in 1855, and by 1861 it stretched from Fort william Frederick to Camp street. Much of the initial expenditure on the wall, however, stemmed directly from the proceeds of licenses that had previously been granted to the city. In

\footnotetext{
${ }^{89} \mathrm{~B} . \mathrm{B} ., 1851$.
} 
$1855, \$ 7,200$ from licenses went towards the works undertaken on the seawall. ${ }^{90}$ This was a major portion of the proceeds from licenses in this year. It was only at a later date that the authorities relieved the city from contributing to the protection of Georgetown from the sea.

In 1860 an ordinance ${ }^{91}$ was passed in which the Combined court agreed to guarantee Georgetown an annual contribution of $\$ 10,000$, in substitution for the contributions made from the proceeds of certain licenses. The system of 1860 was interpreted as an adjustment of the unsatisfactory relations which had existed between the colonial legislative assemblies and the city. In addition, the city was granted the power to assess, levy, and raise taxes, without the blessing of the court of Policy.

The ordinance was an extremely comprehensive one that also provided regulations for the city of Georgetown. The city was divided into 11 "separate and distinct municipal wards" with the incorporation of Albert Town. Within the wards, subdividing lots into units smaller than halves was prohibited, and the erection of houses and other structures was to conform to specific siting regulations in order to avoid high densities. The regulations against fire were particularly stringent:

Every dwelling-house in Georgetown situated on

\footnotetext{
${ }^{90} \mathrm{~B} . \mathrm{B} ., 1855$.

${ }^{91}$ Ordinance No. 25,1860 .
} 
any lot or portion of a lot abutting on either side of Main-street, High-street, Saffon-street or in continuation thereof, and every dwelling house to be hereafter erected to the west of such streets and line, shall be provided with a fireplace or hearth, and a brick chimney and the floor of such kitchen shall be covered with stone, tiles, bricks, or solid earth, and the roof thereof with tiles, slates, or other incombustible material, and if such kitchen is attached to the dwelling-house or any other building the sides and ends of said kitchen shall be of brick, stone, metal or some other incombustible material, or lined therewith; and any existing kitchen so situated not now built in accordance with this section must be altered in conformity therewith to the satisfaction of the Mayor and Town Council within two years from the taking effect of this ordinance; and the Mayor and Town Council may cause any such kitchen to be altered in conformity with the provisions of this section, and may recover the cost thereof by summary execution; and any person acting contrary to the provisions of this section shall be liable to a penalty not exceeding $\$ 500$ to be recovered by the Town clerk in aid of the Town funds. ${ }^{92}$

The prosperous times in the sugar industry had also begun to be reflected in the image of the city. In 1860, an improved street-lighting system was introduced, whereby kerosene was utilized and iron lamp posts newly erected. The streets themselves were improved, widened, and beautified. The impetus to beautification was initiated by the laying out of the Promenade Gardens in 1853. Many exotic species of trees and shrubs were introduced, and these began to line the streets. The fortunes of the city varied with the fortunes of the national economy. Thus, the increasing prosperity of the sugar-based economy undoubtedly

\footnotetext{
${ }^{92}$ Ibid.
} 
had an appreciable influence on the increasing fortunes of Georgetown in the 1850s.

In 1861, public expenditure on Georgetown's hospitals totalled $\$ 80,332$, jails $\$ 21,174$, and seawall $\$ 47,192$. Demerara, the county in which Georgetown is located, received an additional $\$ 54,515$ for public buildings and works, and $\$ 4,700$ for public roads and bridges. New Amsterdam's allocations were more modest; the town was granted $\$ 31,564$ for its mental hospital, and $\$ 7,457$ towards the upkeep of its jail. Berbice, the county in which it is located, received an additional \$17,456 for pubic buildings and works, and $\$ 4,144$ for public roads and bridges. ${ }^{93}$ In the same budget, Essequibo, which had once been the most prosperous region, was allocated the paltry sum of $\$ 12,527$, a clear indication of its loss of pre-eminence.

The primary beneficiaries of public expenditure were the estates. Even when the legislature began extending loans to the villages for the repair of dams, seawalls, roads, and new empoldering, those that benefitted most were the adjacent estates, which reaped the rewards without incurring any costs.

Planters were diligent in suppressing any enterprise that was considered a threat to their industry.. The East Coast Railway, the first railway on the South American continent, which was opened up to Plaisance in 1848 , took

${ }^{93}$ B. B. , 1861 . 
another two years to reach Buxton and 15 years to build the 20-mile line to Mahaica. The company had importuned the government for funds to extend the line at a faster rate, but the sugar planters consistently blocked loans intended for the company. They had little need for the railway, since all of their freight was transported by ship to overseas markets. In addition, planters worried that extending the line would encourage a self-sustaining peasantry to settle along the route, with the Georgetown market at their disposal. This in turn would deprive the plantations of their requisite labor force. With a poorly developed road and transportation system, the peasantry favored the railway; but lacking a voice in the legislature, they were unable to press their claim. In 1866, the Berbice Gazette summed up the detrimental effects of the country's inadequate internal communications system by asking, "What is the use of a man expending his labour in growing articles which he cannot get to market?"14

Water street, the business center of Georgetown, was destroyed by two fires in 1864. The first fire destroyed virtually all of Robbstown including the Royal Agricultural and Commercial Society headquarters, the British Guiana Bank, and stores along water street. ${ }^{95}$ Damage sustained by the merchants and other proprietors, including damage to

\footnotetext{
${ }^{94}$ Berbice Gazette, June 2, 1866.

${ }^{95}$ Rodway 1894, op. cit., vol. III, p.26.
} 
properties and goods, amounted to nearly three million dollars. The second conflagration, though not quite as devastating as the first, succeeded in destroying the congested part of Cummingsburg, and parts of Water street spared by the first fire.

The response of the Court of Policy was immediate. On April 26, 1864, the court passed an ordinance which resolved to layout and rebuild on an improved plan the entire ward of Robbstown. ${ }^{96}$ The objective of the ordinance was to extend and widen the streets so that the city might be safer against future fires. It also endeavored to mitigate the sanitary conditions of the city by authorizing improvements in the infrastructure concerning drainage and sewerage. Another result of the 1864 fires was the establishment of the Georgetown Water Works at Camp and Church streets, and the laying of water mains in the city, in 1866. Merchants had been lobbying the legislature for such a system for 30 years without avail, but the massive losses and resulting disaster relief spurred the planter dominated body into action. The business center of water street and the adjacent business centers was the first to receive the newly laid street lines. Project costs were offset by a city-improvement loan which advanced $\$ 64,000$ in $1865,{ }^{97}$ and

\footnotetext{
${ }^{96}$ Ordinance No. 20, 1864 .

${ }^{97}$ Ordinance No. 2, 1865 .
} 
$\$ 33,100$ in $1866 .{ }^{98}$ New Amsterdam soon followed Georgetown's example, and in 1869 the legislature granted the town $\$ 25,000$ to embark upon a water works scheme to ensure an adequate supply of water in the town. ${ }^{99}$ By contrast, loans for the improvement of villages were never very impressive. In 1867 , a sum of $\$ 4,182.56$ was allotted to the villages, with Mahaica receiving $\$ 250$, Den Amstel $\$ 2,000$, Cumberland $\$ 900$, Daniel's Town $\$ 881.40$, and Golden Grove $\$ 151.16 .100$ In 1868 , village loans amounted to $\$ 14,929.16$, with Blvendaal receiving $\$ 100$, Buxton $\$ 5,549,74$, Friendship $\$ 6,297.21$, Nabacles $\$ 500$, Plaisance $\$ 2,082.59$, and Queenstown $\$ 400.0^{10 i}$ The disbursements were most inequitable when one considered that the combined populations of Buxton and Friendship at this time rivalled New Amsterdam's, and that the villages were plagued with many more formidable problems than the urban centers.

The decade of the 1870 s witnessed a number of notable public works in the country's two urban areas. In 1872, the gas mains were laid in Georgetown; and the city saw its streets illuminated by gas on January 31,1873 . Also, in 1872 a mudwall reinforced with stone was built to serve as the sea defense from camp street to the Kitty. This

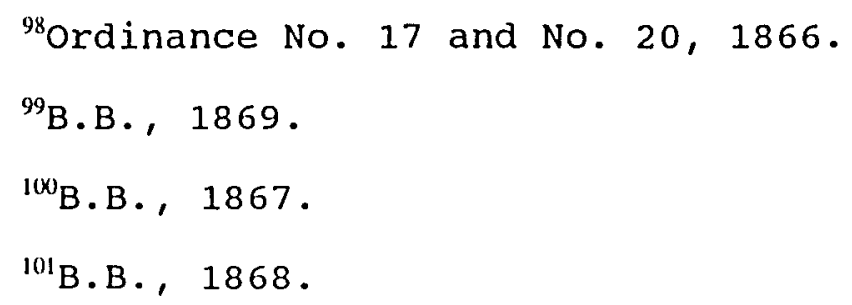


structure was quickly washed away, and in 1874 a concrete wall was commenced. Having reached Kitty, the wall was extended to Turkeyen, a distance of almost three miles, by Quintin Hogg, one of the country's wealthiest plantation owners, at a cost of 80,000 pounds, to protect his estate, Bel Air. ${ }^{102}$ A little later when Hogg encountered additional problems with his sea defenses, this single individual was able to garner a loan of 30,000 pounds from the combined Court to protect his estate. This was a considerable sum when one considers the amount of aid granted to villagers, and even the urban areas. For example, Georgetown's request for a grant of 5,000 pounds to defray the cost of a proposea new system of drainage was denied at a meeting of the Combined Court in April 1876. ${ }^{103}$

Municipal progress continued, however, and both Georgetown and New Amsterdam did benefit from the public treasury. In 1873 New Amsterdam's Water Works commenced, and two years later the government granted the town $\$ 10,000$ to complete the project. ${ }^{104}$ Tram lines were laid in Georgetown in 1877, and in the same year mule-drawn tram cars were introduced into the city. The Botanic Gardens were laid out in 1879 on the site of an abandoned sugar estate in Georgetown. The 276 acres, purchased at a price

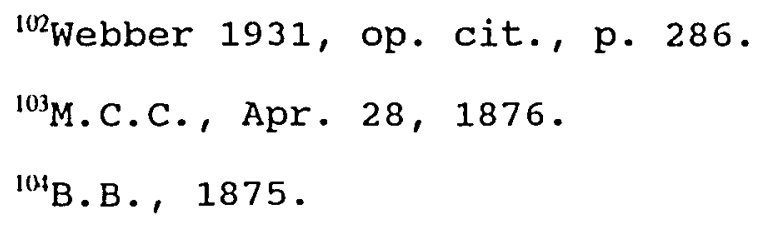


of $\$ 72,000$, provided the city with a significant amount of open space, which along with the tree-lined streets earned Georgetown the appellation of "Garden City."105

Urban development in Georgetown received a major boost in 1876 with the creation of the Bourda Ward. The new ward was formerly part of Plantation Vlissengen and had been purchased by the Combined Court for $\$ 347,200$ in $1874 .^{106}$ ordinance No. 8 of 1876 provided the city with rudimentary developmental regulations concerning the urban plan for the area.

... and such plan shall show the size and extent of the roads, streets, drains, trenches, and of all open spaces, whether between the said lots as laid down or otherwise, which they may consider it desirable should be made, dug, or left open so as best to secure the thorough drainage; sewerage and ventilation of the whole of the said lands, and the proper laying out of the same. ${ }^{107}$

The awareness of the benefits of sound urban planning regulations had been brought to the fore following the report of the Registrar General of Births and Deaths in 1875. His report stated that excessive mortality was the result of:

...the mode in which people lodge, clothe, feed and pass their time... crowding together of numbers of Ranges of cottages covering small spaces of ground... want to proper clothing... to the quality of food eaten, most of it being bought at small and ill ventilated provision shops, not infrequently

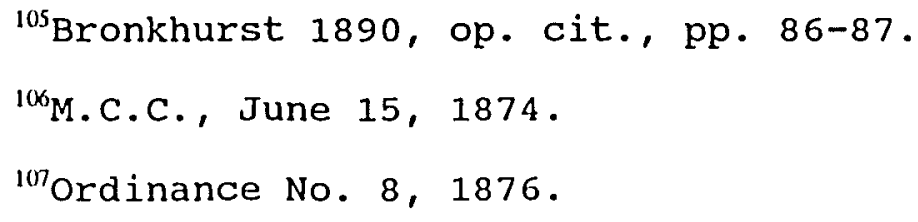


used as sleeping places, to the supply of water as insufficient and bad, especially in dry weather, when in Georgetown, the street taps are the sole resource, and the water delivered through them from the Lamaha is charged with mud and vegetable matter; and in the country the canals and trenches resorted to are in a somewhat similar state... In Georgetown, defective sanitary arrangements are pointed at, and the state of the drains and yards complained of, but until some system of sewerage can be devised, it is despaired of effecting any great change. ${ }^{108}$

The effects of the 1884 collapse permeated the entire Guyanese settlement hierarchy. The crisis resulted in a number of Georgetown merchants becoming insolvent. ${ }^{109}$ Bankruptcies amongst the Portuguese middlemen were the most severe since this group depended on trade with country shopkeepers, who in turn were dependent on the estate workers for their livelihood. Despite the onset of the recession, urban development and planning were pursued in a limited sense in Georgetown and New Amsterdam. On March 28, 1887, an ordinance authorizing the purchase of a portion of Plantation Thomas for $\$ 75,000$ was passed. The land, which was later known as Queenstown, was to be laid out on a plan denoting the size and extent of roads, streets drains, trenches, and all open spaces. Terms of sale were set, and a number of regulations instituted. These included:

A) Prohibiting the subdivision of lots and the establishment of rum and provision shops in certain parts of the district;

B) Regulating the number of such shops in other

\footnotetext{
${ }^{108}$ M.C.P., Nov. 11, 1876.

${ }^{119}$ Rodway 1894, op. cit., vol. III, p. 213.
} 
parts of the district;

C) Regulating the number, dimensions and general character and style of houses to be erected on the lots in different portions of the district. ${ }^{110}$

New Amsterdam abolished its Board of Superintendence in 1891, and a Mayor and Town Council was incorporated to handle municipal affairs. The council was entrusted to assess and raise town taxes; to enforce sanitary superintendence; to exercise control over the public market, slaughterhouse, tanks, pound, and burial ground; and to manage the public fire engines. Cooperages, foundries, smithies, and bakeries were required to have Town Council approval before they could be built inside the town's boundaries. The town's boundaries were delineated to be the ordnance land in the north, Plantations Smythfield and Vryheid in the east, Plantation overwinning in the south, and the Berbice River in the west. Restrictions were placed on the subdivisions of lots and on certain roof-building materials. The ordinance was quite a comprehensive one; even the weeding and cleaning of lots and the use of water were spelled out. The town jealously guarded its water. It was an offense to:

Cause a wilful waste of water from any tap after the vessel placed to receive such water has been filled or by leaving the tap open... or carries avay, or draws from any stand-pipe or tap, water in any barrel or puncheon or other receptacle of a similar nature, for consumption beyond the limits

${ }^{110}$ Ordinance No. 3, 1887. 
of the Town, unless such water has been paid for."11

Also in 1891, Ordinance No. 23 authorized the first electric lights in Georgetown and in the country. In the meantime, conditions on the estates were in a deplorable state. In 1886 , a report by Dr. A.D. Williams of the Immigration Department noted that the houses, hospitals, water supply, and drainage on the estates were far from ideal and did not even meet minimum acceptable standards. The planters took umbrage against williams' report and in 1887, through their domination of the Combined court, reduced his salary to one cent in the following year."12

In the villages a meager rural improvement grant of $\$ 25,000$ had been instituted for a number of years, but the depression offered the combined court an excuse to reduce the grant, and by 1892 the grant had been completely eliminated. The planters could point out, with some justification, that between 1884 and 189140 sugar estates had become insolvent. ${ }^{113}$

Public infrastructural expenditure allocations between 1886 and 1892 were also in favor of the sugar estates, and to a lesser extent the towns. Adamson ${ }^{114}$ outlined the following major allocations:

\footnotetext{
"III Ordinance No. 15, 1891.

${ }^{112}$ M.C.P., Oct. 11,1887 .

${ }^{113} \mathrm{~B} . \mathrm{B} ., 1884$ and 1891.

${ }^{114}$ Adamson 1972, op. cit., p. 246.
} 
1. Sea defenses, Plantation Bel Air (Q. Hogg) $\$ 109,440$

2. Fresh water works (Lamaha, Boerasirie, and East Demerara water supply commissions, all concerned principally with the water supply to sugar estates)

Total of principal benefit to sugar estates $\$ 589,386$

3. Sanitary improvements (New Amsterdam and Georgetown) and new market (Georgetown) \$286,500

During the same period, Adamson remarked that the amount spent on village water supply systems was a trifling $\$ 31,271 .^{115}$

At the turn of the century, the deteriorating social conditions in the city contrasted with the continued development of its infrastructure. Georgetown was receiving a significant amount of revenue from the government coffers. For example, the principal items of expenditure for 1895-96 included $\$ 136,699$ for grants in aid of sugar estate roads, $\$ 54,254$ in special grants for sanitary improvements in the municipalities, a $\$ 505,996$ loan to Georgetown, and a $\$ 89,496$ loan to New Amsterdam. 116 Infrastructural expenditure in the towns, however, must be assessed with some caution. one cannot simply consider urban areas to be monolithic entities and thereby reduce inequities to conflicts among the towns, villages, and estates. Within the urban areas themselves, there were tremendous intra-urban inequalities, not only in infrastructural allocations, but in housing, jobs,

$$
\begin{aligned}
& { }^{115} \text { Ibid. } \\
& { }^{116} \text { B. B., } 1895-96 .
\end{aligned}
$$


education, social services, etc. In Georgetown, the northern wards, peopled by the ruling class (merchants, government officials, and representatives of the plantocracy), were much better served than the poorer southern African-Guyanese wards.

On August 1, 1900, the railway line from Georgetown to Mahaicony was extended to Rosignol on the Berbice River. Unfortunately, New Amsterdam's port sustained the loss of its steamer service with Georgetown, following the completion of the Georgetown-to-Rosignol railway. The Governor, believing the steamer service was now unnecessary, summarily suspended it in $1900 .^{117}$

The dawn of the new century witnessed the commencement of the running of electric trams in Georgetown. The company operating the trams was required by ordinance to have an office in Georgetown. ${ }^{118}$ It appears that at this time all large companies operating in Guyana were obliged to set up company offices in the capital city. The built-up area of the city and its population were augmented by the incorporation of Wortmanville, one of the poorer southern suburban areas, into the city. ${ }^{119}$

During World War I, increasing exports of sugar and rice brought a measure of prosperity to the two urban areas,

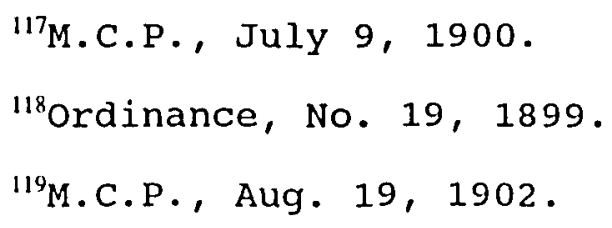


and to Georgetown in particular. In 1913, Albouystown was incorporated into the city of Georgetown, following the passing of ordinance No. 20.120 In the same year the city's water supply received a major boost when the pumping capacity of the water works was increased and the mains were extended almost 50 miles. The combined court secured $\$ 20,000$ to permit the drilling of artesian wells in the country. The first well was sunk in Georgetown, at D'Urban Park, which proved to be a success. Not to be outdone, the plantocracy, citing the country's newfound wealth, formulated a sea-defense scheme for the protection of their estates along the coast. In August of 1916, construction of permanent ferro-concrete seawalls and groynes was begun at Plantation Lusignan on Demerara's east coast, and subsequently at plantation clonbrook a few miles further down. Schemes were also prepared for the west coast of Demerara, the Essequibo coast, the Corentyne coast, and the islands of Leguan and Wakenaam. All told, the estimated cost of the project was put at $\$ 4,476,558.121$

Revenues, however, were deemed insufficient to construct a railway line connecting Georgetown with Manaos

${ }^{120} \mathrm{~B} . \mathrm{B} ., 1913-14$

${ }^{121}$ British Guiana. 1919. Report on the condition of the Colony of British Guiana During the Great European War, and on the Chief Local Problems Awaiting Solution. Georgetown: The Argosy Company, p. 65. 
and Boa Vista in Brazil. ${ }^{122}$ Hinterland development and penetration were still frowned upon for fear that the labor force would abscond into the interior. In any case, the soils, as the Dutch had discovered, were not conducive to sugar-growing, and thus did not warrant public expenditures. No penetration roads were built; and Guyana, although sharing a wide expanse of borders with Venezuela, Brazil, and Surinam, was virtually isolated from these neighboring countries. External communications with the core were paramount - they were needed to evacuate exports - whilst internal ones could be served by the 324 miles of coastal roads from Pomeroon to the corentyne River. ${ }^{123}$ In total, Guyana possessed a little over 400 miles of public roads in 1917, and this total included the 47 miles of roads in Georgetown and 12 miles in New Amsterdam. The amount is extremely paltry when compared with that of the much smaller British West Indian Islands. For example, Trinidad with an area of 1,754 square miles possessed 2,255 miles of public roads, Jamaica with an area of 4,450 square miles 6,459 miles of public roads, and tiny Barbados with an area of 166 square miles 470 miles of public road. ${ }^{124}$

$$
\begin{aligned}
& { }^{122} \text { M.C.P., } 1914 . \\
& { }^{123} \text { B.B., } 1917 . \\
& { }^{124} \text { British Guiana } 1919, \text { op. cit., pp. 30-31. }
\end{aligned}
$$




\section{Land Use}

Among the land use measures which were implemented by the legislature and may be considered here, are the crown Lands regulations, land settlement schemes, assistance in developing new towns such as Hopetown, and neglect of others such as Bartica.

The plantocracy and the Colonial Government did not anticipate the concentration of African-Guyanese in the coastal villages. They feared that with complete emancipation the ex-slaves would migrate en masse into the interior of the country, where they might exist entirely out from under any governmental control. Hoping to avert this potentially disastrous scenario of total independence and anticipated anarchy, the government sought to restrict access to land in the interior. No such restrictions were evident in the smaller Caribbean islands, where limited territorial size restricted the capacity of ex-slaves from completely severing their connection with the plantations. Nevertheless, newly freed slaves in countries such as Jamaica, were able to resist further exploitation by moving into the interior and into the mountains. There they established themselves as peasants and small scale farmers growing and marketing ground provisions and other crops independent of the plantations. ${ }^{125}$

${ }^{125}$ Carnegie, c. (ed.). 1987. Afro-Caribbean Villages in Historical Perspective. Kingston: African-Caribbean Institute of Jamaica. 
All lands not privately owned in Guyana were known as Crown Lands (i.e., land owned by the British Government). After emancipation most of the country (including nearly all of the interior) fell under this designation. Initially Crown Lands were available free of charge, provided that purchasers were willing to develop the land according to certain stipulations. However, on March 5, 1831, the Colonial office required Crown Lands to be sold at five shillings per acre, and restricted sales to grants of up to 100 acres. ${ }^{126}$ The set price was extremely low. As complete emancipation approached, Governor Light felt it necessary to issue the following warning:

If persons without capital will consider themselves entitled to demand land, let them not possess it without such restrictions as shall induce them to pause before they quit the more densely peopled regions for the interior. ${ }^{127}$

With the commencement of the village movement in 1838 , the government felt that a bolstering of the crown Lands regulations was necessary. Consequently, on May 28, 1839, the Secretary of state for the Colonies, Lord Glenelg, promulgated new Crown Lands regulations. The minimum size of purchased lots was to remain at 100 acres; however, the statutory upset price was raised to four dollars and eighty cents per acre. The move was intended to inhibit laborers

\footnotetext{
${ }^{126}$ Davis, D. 1888. "The Records of British Guiana." Timheri 2, p. 346 .

${ }^{127}$ Farley, R. 1954. "The Rise of the Peasantry in British Guiana." Social and Economic Studies 2, p. 97.
} 
from acquiring land in the interior beyond the coastal plantations. In a sense, the government was successful; there was little migration southwards. This was perhaps more a result of other distinct conditions which prevailed at the time, than it was a policy triumph.

Peasant proprietors had little intention of migrating into the vast hinterland, when it was abundantly clear that the coastal lands were more fertile, better drained and irrigated: coastal areas possessed other infrastructural works that were available at extremely competitive prices. Even when prices began to skyrocket and land on the coast was selling at a hundred times the cost of Crown Land, the workers did not opt to buy Crown Lands. To venture into the interior would have, in addition, denied themselves access to markets (especially for imported consumer goods), churches, schools, and the sugar plantations from which they could supplement their incomes.

Besides migrating to the villages and establishing new ones, African-Guyanese who could not afford to purchase estates or land squatted on the crown Lands in the interior. The "Commission Report in British Guiana" noted in 1848:

There are great numbers too, who strictly speaking squat up the rivers and creeks, that is, settle themselves on crown land without any title whatever. The forest teeming with game and the rivers with fish, afford them plentiful subsistence; and the ground with very little tillage yields them an abundant supply of provisions. They carry on a small trade in firewood, charcoal, etc., but by day the greatest part of their lives is spent in 
absolute idleness. ${ }^{128}$

Alarmed by this new development, the government increasingly began to enforce the vagrancy laws. Woodcutting and timber permits were increased, and in some cases Amerindians were given preference on timber grants, all in an effort to keep the African-Guyanese on the plantation belt and to suppress settlement in the interior. The spatial and economic subjugation of the African population was exacerbated by the decision of the ruling class to enact an ordinance in $1852,{ }^{129}$ which prohibited the collective purchase of land by groups of more than twenty persons. This piece of legislation was supported by another in $1856,{ }^{130}$ which reduced joint purchases of land to 10 persons, and stipulated that the land so held was to be converted into individually owned plots subject to monthly rates for the upkeep of drainage, roads, bridges, and other infrastructural costs. Naturally, no such levies were applied on the sugar plantations. The effect was to further stymie the village movement, and to make this segment of the population more dependent on plantation labor.

Having ensured the demise of the village movement, the legislature once again turned its attention to the crown

${ }^{128}$ Augier, F. and S. Gordon. 1962. Sources of West Indian History. Bristol: Longman, p. 160.

${ }^{129}$ Ordinance No. 1, 1852.

${ }^{130}$ Ordinance No. 33, 1856. 
Lands of the interior. There was a certain amount of apprehension among the ruling class that the failure of the African-Guyanese coastal villages might fuel purchases of Crown Lands, which did not require the kinds of heavy capital investment associated with land development on the plantation belt. Hence, in 1861, the authorities utilized their legislative powers by stipulating that crown Lands could be purchased only in minimum parcels of 100 acres, and at the prohibitive price of $\$ 10$ per acre. This was roughly five times the cost of land available elsewhere on the coast and on some of the rivers. ${ }^{131}$ Reflecting on the government's policy, the Administration Reports of 1881 concluded that the sale price of crown Lands was an effective deterrent to African-Guyanese settlement in the interior. ${ }^{132}$

The policy of confining the population to the plantations did not apply to all sections of the community. The Portuguese had already been encouraged to leave the plantations; and in 1865, the legislature sought to retain Chinese immigrants who had completed their indenture in the country, by assisting them in establishing an exclusive Chinese settlement. A loan of $\$ 2,262$ was advanced to one 0 . Tye Kim to survey and layout a settlement, Hopetown, on the

${ }^{131}$ Veness, W.T. 1867. El Dorado: or British Guiana as a Field for Colonisation. p. 7 .

${ }^{132}$ Administration Reports 1881. 
Camoonie creek. ${ }^{133}$ The decision to accord the chinese favorable status was not a difficult one, since their tenure on the plantations was not proving to be a profitable one for the planters. As early as 1863, Governor Hincks, referring to Chinese immigration, warned:

...it will be desirable to abandon it. There is, I think, no reason to doubt, that the labour market of this colony can be sufficiently supplied from India. ${ }^{134}$

For a time Hopetown was quite a prosperous settlement. It began with 25 inhabitants in 1865, and expanded to 567 in 1871 and 800 in 1874 . The settlement subsequently declined in 1881 when its population fell to 222 , and by 1914 the community numbered only 73. The failure of the scheme stemmed from a number of factors including soil exhaustion, inadequate drainage, and the paucity of women in the community. In addition, many left the settlement to join their counterparts who had migrated to the urban areas or had become small-shopkeepers in the rural areas.

In 1869, more than 30,000 Indian immigrants, by completing their indentureships, had earned the right to be returned to their homeland at the government's expense. With an estimated repatriation cost of a quarter of a million dollars, not to mention the expected depletion of the labor force, the legislature was determined to keep the

\footnotetext{
${ }^{133}$ B. B. , 1865 .

${ }^{134}$ M.C.C., April 14,1863 .
} 
Indians in the colony. ${ }^{135}$ New Indian immigrants were still being introduced into the country, but those who had completed their terms of servitude were being pushed out of the estates. Consequently, the planter-dominated legislature required a strategy with which they could alleviate the costs of repatriation, and at the same time direct the Indian to specific locales where his labor could still be of service at critical times and his presence near the estates would serve to dampen wages. The solution was found in the development of land settlements. Immigrants were to be offered land in return for the commutation of their rights to return home.

The first attempt at land settlement was the government's purchase of Plantation Nooten zuil on the east coast of Demerara, in 1872 , for $\$ 15,000 .{ }^{136}$ The project was a resounding failure. Indian immigrants refused to take up allotments, and by the following year the settlement scheme was abandoned. Indians complained that the site was unsuitable, that the grant of two-and-a-half acres (later increased to three) was inadequate, and that the restrictions on cattle rearing were unacceptable. In reality, immigrants preferred to choose their own land. With a newfound freedom of movement, following the end of reindenture in 1873 , it was found that the Indians were

\footnotetext{
${ }^{135}$ Ruhoman 1947, op. cit., p. 149.

${ }^{136} \mathrm{~B} . \mathrm{B} ., 1872$.
} 
moving off the estates at a rate of 3,000 per annum. ${ }^{137}$ Settlements sprung up in an unorganized fashion along the public road of the coastal strip. Indians were purchasing and renting lands from private individuals and in some cases were occupying lands in the African-Guyanese villages. No settlement at this time was exclusively Indian, and there is no evidence to suggest that immigrants were attempting to segregate themselves.

Segregation, however, was fostered by the legislature, which in 1880 once again revived the idea of land settlement with the purchase of Plantation Huis T'Dieren on the Essequibo coast. The land was drained, laid out into cultivation lots, and offered exclusively to Indians. African-Guyanese who had been residing on the front-lands of the plantation were asked to leave. Given the difficulties experienced by the Africans following the emancipation, and their efforts at creating their own villages, many viewed land settlement as a discriminatory practice. A petition was presented to the court of Policy by "artisans, shopkeepers, peasants, and labourers" in which for the first time they outlined their opposition to immigration, their fear of the exodus of Indians into the settlements, and the costs entailed.

That your petitioners are in a most lamentable state of poverty, notwithstanding the ring of fertility and vast extent of the colony. They

${ }^{137}$ Adamson 1972, op. cit., p. 94. 
ascribe this almost universal state amongst them to the unusual drain upon the colony during the last 35 years for the support of an altogether erroneous system of immigration. A system wholly incompatible with the principles of political economy as recognized by Eminent statesmen; incompatible with justice; and must therefore, ultimately culminate in ruin...

Your petitioners beg to be distinctly understood, that they are not wanting in good will towards these immigrants as a people; their complaint is altogether against the manner in which they have been introduced, and all the consequent evils. ${ }^{138}$

Despite the appeasing tone of the petition, race had become the bogeyman, obfuscating the struggle against the plantocracy, and capital in general.

The Huis T'Dieren scheme attracted a large number of applicants, but only 73 immigrants waived their rights to return passages in order to settle there.

With Indians buying their own lands, a new strategy was instituted by Governor Irving in 1882. He felt that land settlements were a needless waste of public expenditure, and that the government would be better served by easing the restrictions on Crown Lands. Land could now be purchased in two-and-a-half acre lots at a price of $\$ 25$ per acre. However, the price was too high, since land elsewhere could be bought privately for $\$ 5$ per acre or less. Thus, in 1885 a new Crown Lands ordinance was passed, stipulating that land within 10 miles of a public road (essentially the road along the coast connecting the estates) was reduced to $\$ 10$ and at the same time no one

\footnotetext{
${ }^{138}$ M.C.P., Nov. 8, 1880 .
} 
could buy fewer than 100 acres, whilst the price for crown Lands elsewhere in the colony was maintained at its high price. Neither the government nor the planters were yet prepared to sanction the possibility of settlement in the interior. The effectiveness of the Crown Lands policy, from the planters' point of view, can be discerned by the mere fact that only 22 grants of Crown Lands were made to private individuals between 1839 and 1885, and only two were issued between 1885 and $1890 . .^{139}$

Irving further persuaded the combined court that it was in their interest to facilitate the development of the emerging village settlements. And in 1883 villagers were relieved of the onerous costs associated with the maintenance of public roads and bridges. Public expenditures to the villages were increased, but most of the funds were allocated to a few villages along East coast Demerara, between Georgetown and Mahaica.

Gold was discovered in the 1880 s, primarily in Essequibo, and in an effort to keep tabs on the industry, it was found necessary to establish a town at Bartica on the Essequibo River. The site was an excellent choice, for it embraced three rivers, Essequibo, Cuyuni, and Mazaruni, from whence much of the widely distributed gold was extracted. It also permitted some riverain communication between the coast and the interior. Ordinance No. 5 of 1887 was passed

${ }^{139}$ M.C.C. , 1898 . 
for the establishment and regulation of a town at Bartica. The Crown Surveyor was asked to prepare a plan denoting the size and extent of the roads, streets, drains, trenches, wharves, stellings, and open spaces to be made or reserved, and of the building lots and other lots to be sold. The town was the first significant settlement in the interior since the migration of estates to the coast over a century earlier. Two years later, in 1891, Morawhanna, a settlement in the North-West District was laid out, but the settlement was never a success. In sketching the rationale for Bartica's development, Henry Kirke, a government employee, surmised:

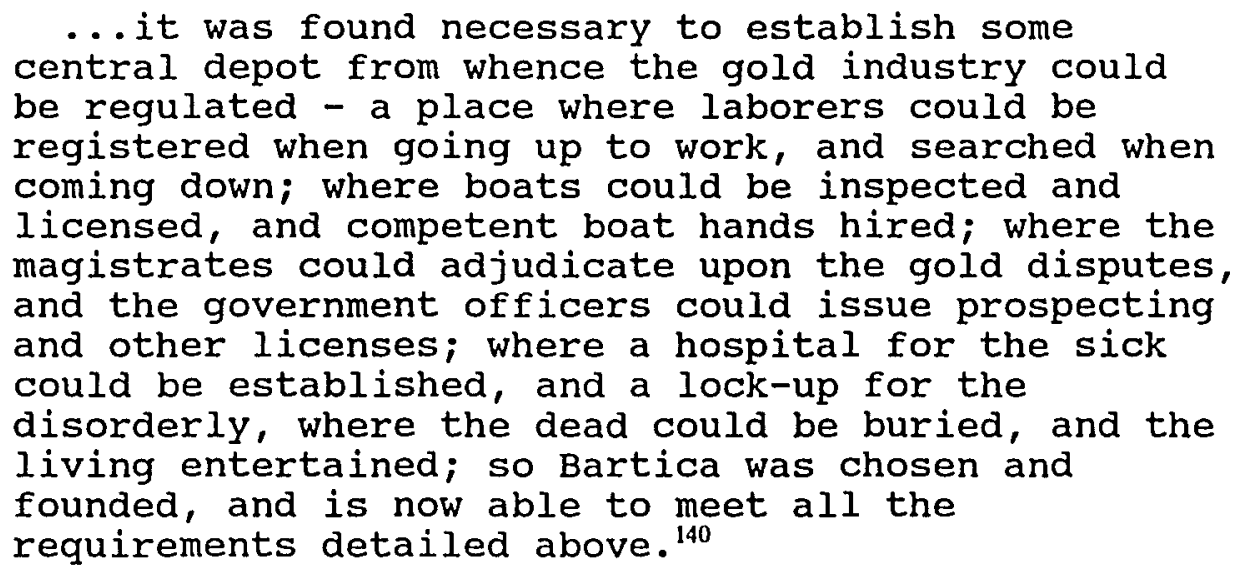

In 1902, the court of Policy met to discuss the idea of making Bartica the capital of the country. One member suggested that Bartica was going to be not only the capital of the colony, but the "Liverpool of the western seas."141

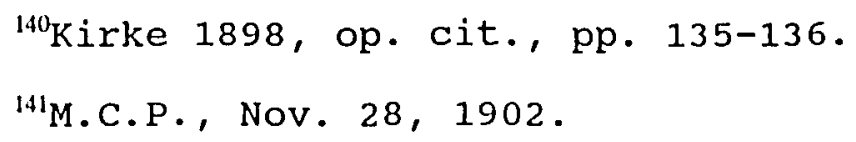


Since its foundation, the town had been gradually rising in importance, but its population was constantly fluctuating depending on the fortunes of the gold-mining industry. Furthermore, planter capitalists, and a number of Georgetown merchants, steadfastly resisted hinterland infrastructural expenditure. The proposal was quickly shelved, and Bartica continued to be omitted from the country's transportation network. There was to be no national integration of the spatial economy.

The government never sought to allow the establishment of settlement on the gold fields themselves. The interior was useful because it provided a safety valve for unemployed Africans, but permanent settlements in the interior were never seriously contemplated. The fortunes of the country and its population distribution were to remain a coastal affair.

In 1894, the planters once again broached the subject of granting lands to Indians in lieu of return passages. A commission was appointed to enquire into the feasibility of such a policy; and in 1896, following its recommendations, Plantation Helena on the east coast of Demerara was purchased by the government, and 1,206 Indian immigrants commuted their rights to return passages for grants of land on the settlement. ${ }^{142}$ Subsequently three other estates, Bush Lot on the west coast of Berbice, Whim on the Corentyne

$$
{ }^{142} \text { B. B. , } 1897-98 \text {. }
$$


coast of Berbice, and Maria's Pleasure on the island of Wakenaam on the Essequibo, were acquired for settlement. The settlements progressed slowly, and although 2,300 immigrants had taken up grants by 1901, the government was dissatisfied with the results and once again abandoned settlement schemes in 1905 .

The success of the schemes was probably hindered by the countervailing effects of the government's crown Lands policy. This policy had been liberalized in 1898 so that Crown Lands could be purchased in 25-acre lots at a price of 15 cents per acre, and the incidental expenses connected with acquisitions were lowered at the same time. As a result, Indians took advantage of the new regulations, and began securing lands that were suitable for rice cultivation in the Mahaica, Mahaicony, and Abary Creeks, and on the Corentyne River. In addition, many private land sales were concluded at this time. The number of Indians who were now living off the estates and in the villages and settlements had doubled from 28,412 in 1891 to 57,649 in 1901 .

In 1912, land settlements were once again contemplated by the government as a means of encouraging Indians to remain in the colony. Between 1912 and 1913 the government purchased Plantations Unity, Lancaster, and clonbrook on the east coast of Demerara, and Windsor Forest, La Jalousie, and Hague on the west coast. The lands were drained, laid out into cultivation plots, and sold to Indians. The increasing 
movement into rice cultivation meant that for the first time since the Dutch era, crops other than sugar had more lands under cultivation. During the 1912-1913 period, the sugar estates were cultivating 74,544 acres, rice took up 41,722 acres, and ground provisions and other crops 34,492 acres. Whilst this is important, one needs to bear in mind that at this time the sugar estates (41 of them) had 77,424 acres, or 51 percent of their land, idle. ${ }^{143}$ sugar estates maintained a policy of keeping lands fallow as part of their crop rotation system, but this does not explain the vast amounts kept by the industry. Certainly the industry had the most fertile land, and it is possible, given the vagaries of world markets, that a healthy reserve was required to take advantage of possible opportunities. In any case, the custom of granting extensive tracts of land to individuals and companies came to an end in 1913, and was replaced by a policy of granting leases.

\section{Political and Social structure}

Politics is a key causal variable behind demographic concentrations. Thus, expenditures and infrastructural provision are analyzed as a function of the political power of various groups in the society. For example, the ability of planters or merchants to articulate their demands was dependent on their control or influence over the court of

\footnotetext{
${ }^{143}$ B. B., $1912-1913$
} 
Policy and the Combined Court. This sub-section assesses the political power of these groupings during the period. It looks at the way qualifications for the franchise were used as a device to exclude certain segments of the population, and at the efforts by the government to divide the variegated ethnic groups.

Government expenditure had increased markedly following emancipation. With the costs associated with social control now absolutely in the hands of the state, and with the introduction of education, health, and other social services underway, public expenditure had almost doubled from 130,017 pounds during the 1838-40 period to 214,043 during the 1841-43 period. ${ }^{144}$ Naturally, the planters ensconced in the Combined court and the court of Policy had no intention of bearing the new costs; thus, pressure was brought to bear on the African peasantry and their petty commodity producer counterparts in the urban areas. Villagers who sought to be subsistence farmers were coerced into the wage economy by the government's shifting of the tax burden onto the peasantry. For the sale of the smallest quantity of provisions, laws were introduced requiring shop and hucksters' licenses, porters' licenses, taxes on carts for hire, etc. The substantial fee that was required possibly served to underdevelop internal trade and to strengthen the position of the large-scale merchants and

\footnotetext{
${ }^{144}$ Adamson 1972, op. cit., p. 243.
} 
traders in the country. Import duties were designed specifically to fall on the peasantry, and at a later date the indentured immigrants. Common items consumed by this group (such as rice, pickled pork and beef, and corn) were assigned steep duties. The plantocracy calculated that high taxation and import duties on these items would force the working class to labor on the plantations, and thus become economically dependent on them. Meanwhile, articles thought to be essential to colonial life were exempted. In 1850, duty-free articles included sheep, hogs, cattle, fresh fruit and vegetables, fresh fish, fresh meat, poultry, turtles, manures, Iumber and varnish, machinery, provisions for the forces, ice, wines and spirits imported by the governor, and higher-income consumer items such as coin, bullion, and diamonds. Furthermore, the income tax fell directly on the ruling class. It was introduced following the termination of the poll tax on slaves, reduced from 2 to 1 percent after 1842, and abrogated in 1853. ${ }^{145}$ Planters had previously been exempt from taxes on income gained from cotton, coffee, sugar, rum, and molasses.

Restricted from private enterprise, the African population sought opportunities in other areas. The education field became an important source of employment, especially for those who had migrated to the towns. Education was viewed by the migrants as a means of social

${ }^{145} \mathrm{~B} . \mathrm{B} ., 1853$. 
and economic mobility. Some entered the teaching profession, whilst others aspired to become lawyers and doctors. The growth of the civil service and its centralization in Georgetown meant that educated migrants were soon being recruited for lower-grade clerical positions in the city. In March 1852, a Central Board of Health was created in Georgetown, with the responsibility of managing smaller local boards in other parts of the colony. The effort to educate the African population was met with a certain ambivalence by the planters. On the one hand, they felt that education might spur greater opposition to their privilegea position in the society; and on tine other, they recognized its socializing effect, in the sense that formal education could foster obedience and an acceptance of the unequal structures in the colony. As the 1850 s progressed, it seemed that the latter view was in ascendance. Migrants who wished to be educated in the city were assisted by the establishment of Bishop's College in 1851 and Queen's College Grammar School in 1853.

Guyanese merchants also fared poorly when the planterdominated Combined Court stopped supplies in 1840. The curtailment of supplies meant that for nearly six months, little business could be transacted in the urban areas where the merchants were to be found. Merchants objected to the narrow oligarchy which dominated the Combined court. Membership on the Court of Policy and Combined Court, and 
qualifications for the franchise, were overwhelmingly based on the ownership of land. Thus, participation in the political process favored the planters, although a monetary value was included as part of the requirements following the abolition of slavery.

Reforms of the franchise failed to increase significantly the electorate, for in 1847 there were only 561 registered voters out of a population of 130,000. The necessity for the broadening of the franchise was further demonstrated on May 8, 1849, at an election for a member of the college of Kiezers. When the votes were tallied, it was found that there were only 169 votes, and that none were from Berbice. At another election in August, 1849, the number of voters in the colony were only 88. Absentee voters numbered 181, of whom no fewer than 134 were represented by five persons, who thus with their own votes were able to determine the outcome. ${ }^{146}$

In the fall of 1849, following some intense lobbying by the merchants and a reassessment of the situation by the Colonial office, the franchise was extended to include the following stipulations: 1) for rural voter - freeholders in possession of three acres of land under bona fide cultivation, or ownership of a house or house and land with a value of $\$ 96$ per annum; or leaseholders of six acres of land under bona fide cultivation, or tenancy of a house or

\footnotetext{
${ }^{146} \mathrm{Clementi} 1937$, op. cit., pp. 187-188.
} 
house and land with a value of $\$ 192$ per annum; 2) for city or town voter - ownership of a house or of a house and premises of an appraised value of $\$ 500$; or leaseholders paying an annual rent of $\$ 120 ; 3)$ for those not specified in the above two categories - residence in an electoral district for six months and an income or salary of not less than $\$ 600$ per annum; or persons paying $\$ 20$ a year in direct taxes. ${ }^{147}$

The first elections under the new constitutional arrangements were held in 1851 , but these resulted in an increase in the number of voters to only $916 .{ }^{148}$ The requirements were so stringent that few voters were able to participate. Although there were 11,000 African-Guyanese landed proprietors at this time, many owned relatively small lots which did not meet the new franchise qualifications. Moreover, those African-Guyanese who did meet the requirements were excluded from the electorate by the imposition of a subjective literacy test that was inserted into the 1840 ordinance at the insistence of the planters. ${ }^{149}$ The vote of women, which had been in effect since Carmichael's proclamation of 1812, was also taken away by Ordinance No. 15 of 1849 .

\footnotetext{
${ }^{147}$ Ordinance No. $15,1849$.

${ }^{148}$ B. B. , 1851 .

${ }^{149}$ Official Despatch, Barkly to Grey, oct. 5, 1849.
} 
Planters further restricted membership in the college of Kiezers and the College of Financial Representatives by imposing property qualifications which were higher than those required for voters. Prior to 1849 , qualifications for the colleges and the franchise were the same, but since there was the danger that the lower franchise requirements might introduce Africans into the legislature, new eligibility standards were introduced. Membership into the two colleges were set at ownership of not less than 80 acres of land, of which 40 should be under cultivation; or the possession of a house, or house and land, with an annual rental value of $\$ 1,200$; or possession of an annual income of $\$ 1,440$ derived from any other kind of property, or from the profits of any trade or profession. siding with the planters on this point, Governor Barkly reasoned that the high qualifications were necessary "in order to secure as high a standard of independence and mental cultivation in the political colleges of British Guiana.".150 Even the clergy were banned from membership in the colleges. The planters feared that the clergy would use their power in the legislature to further the cause of the African masses. Governor Barkly acknowledged this point and presented his own convoluted argument to keep the clergy out.

One class alone, the ministers of religion, are excluded, however qualified in other respects, from a seat in the legislature - an exception justified 
by its proposers on the analogy of the British House of Commons, and acceded to on my part, not from any jealousy of the influence exercised over the Emancipated peasantry by their spiritual guides, but from a conviction, on the contrary, that this influence would be diminished by their interference in secular affairs, instead of being, as I would gladly see it for the interests of religion and morality, extended tenfold. ${ }^{151}$

However, the new system did favor wealthy merchants and professionals in Georgetown and New Amsterdam, since there was no direct taxation or similar monetary remedy which could enfranchise those in the rural areas. Voter registration in 1849 clearly indicated that urban interests had made significant headway under the new law. Nearly 41 percent of the registered voters were residents of Georgetown, whilst New Amsterdam accounted for over twothirds of Berbice's voters. ${ }^{152}$ The plantocracy had feared the likelihood of this new power alignment, and had cleverly lobbied for the creation of electoral districts that would give rural districts a majority of seats in the constitutional assemblies. The result was that rural districts were assigned four representatives each to the College of Kiezers ${ }^{153}$ and the College of Financial Representatives, ${ }^{154}$ whereas Georgetown was permitted two

${ }^{151}$ Ibid.

${ }^{152}$ B. B. , 1849 .

${ }^{153}$ The body from which members of the court of Policy were selected.

${ }^{154}$ Members of whom, along with the court of Policy, constituted the Combined court. 
Kiezers and one Financial Representative, and New Amsterdam one of each. Consequently the merchants were, on paper, outnumbered by the planters three to four in the college of Kiezers, and two to four in the college of Financial Representatives. The new alignment met with unqualified support from the Colonial Government. In a despatch to Governor Barkly, Earl Grey wrote:

My belief is that, in such a state of society as now exists in Guyana, it generally happens that the capital town is apt to exercise too much, rather than too little, influence as compared with the rural districts, even without the addition which such a change would make to its power. ${ }^{155}$

Corporate proprietorship further reduced the strength of the old plantocracy, but the hold of the sugar industry on Guyana's structures did not wane. When "gold fever" broke out in Georgetown and elsewhere in the colony in 1864, ${ }^{156}$ following the first organized attempt at mining in the interior, it was rumored that the planting body, as well as the Colonial Government, pressured the company's geologist to present an unfavorable survey. ${ }^{157}$ The authorities and planters had feared that thousands of wouldbe miners would depart the coast, leaving the sugar industry in ruins. It must be noted that no such uproar attended the establishment of the cattle industry in the Rupununi in

${ }^{155}$ Earl Grey's despatch, Dec. 30, 1850. In Clementi 1937, op. cit., p. 219 .

${ }^{156}$ Royal Gazette, Oct. 14, 1864 .

${ }^{157}$ Rodway 1894, op. cit., vol. III, p. 189. 
1860, or the Balata industry elsewhere in the interior in 1862. The fact that these industries were not very laborintensive no doubt influenced planter response.

Planter hegemony of the country's political structure was briefly challenged in 1863 by the election of six white merchants to the combined court. Urban dominance was further strengthened, since elected planters often had great difficulty attending meetings in Georgetown. Merchants quickly sought to flex their newfound muscles by attempting to nominate a Georgetown lawyer to the court of Policy, although he did not possess the necessary landed-property qualification. The merchants directly challenged the planters by contending that membership on the court of Policy had never been defined since the days of slavery. However, with matters at a head, the plantocracy skillfully persuaded the Colonial office to set a qualification standard of 80 acres for membership on the court. ${ }^{158}$ This effectively barred the merchants and other non-white groups from membership on the court.

Planter domination was not confined to the political structures of the colonial state. Members of the plantocracy dominated just about all the statutory boards including drainage, health, sea defense, and village administration. Moreover, they exercised considerable power over the local press, particularly the Royal Gazette, the 
local militia, the police, and the judiciary. This is quite apart from the fact that they also reigned supreme over the country's social and economic structures through their ownership of the plantations.

The plantocracy and colonial government were also quite adept at exploiting the racial differences of the various groups to solidify their hold on Guyanese society. One plantation manager summed up the "competing races" philosophy the following way:

I think the safety of the whites depends very much upon the want of union in the different races of labourers and I should be glad to see some more Madeiranese and, if possible, chinese, coming in; the coolies [Indians] too would always hold by the whites. ${ }^{159}$

The various racial groups were thus expected to form a social buffer between the ruling class and the emerging African population. Furthermore, the plantocracy reasoned that a racially diverse population could easily be translated into a divided labor force. The Portuguese, perhaps because they were phenotypically white, received the most favored treatment. Not only were they encouraged to take over the retail trade, but even when they were laboring in the fields, they were paid at a much higher rate than their counterparts from other groups. The Portuguese laborer was paid $\$ 28$ a month, whilst the Indian was paid

${ }^{159}$ Quoted in Adamson 1972, op. cit., p. 157. 
$\$ 21$, or 25 percent less. ${ }^{160}$ The pro-Portuguese policy in time led to conflict between this group and the African in particular. The first clash came in 1848, and this was followed by the Angel Gabriel Riots of 1856, and further strife in 1862, 1889, and 1891. African antipathy toward the Portuguese stemmed primarily from economic considerations. Many Portuguese retailers charged high prices, and were guilty of fraudulent retailing practices in their dealings with their African customers. However, Rodway attributes the ill feeling of the African-Guyanese towards the Portuguese to deep-seated racial prejudices.

In the opinion of the negro he [i.e., the Portuguese] was a low fellow, not a "buccra," or gentlemen, nor the ideal white man. Then he was a Roman Catholic, whilst most of the blacks were rabid Protestants; this was an offence. Beyond everything he had driven out almost every peddlar and small shopkeeper of the coloured race by underselling, and could get credit where a black man's application would have been treated with contempt. It was the oft-recurring complaint against the foreigner, for the negro was the native or creole who alone had the right to prosper in his own country. ${ }^{161}$

Africans also clashed with Indians and chinese, but these skirmishes were never serious in the nineteenth century. The introduction of greater numbers of white women also contributed to the widening gulf between the races in the late 1800s. According to kirke, white women regarded with disfavor relationships between whites and non-whites,

\footnotetext{
${ }^{160}$ Webber 1931, op. cit., p. 220.

${ }^{161}$ Rodway 1912, op. cit., p. 127.
} 
and the "touch of the tar brush" became less acceptable to the English colonists. ${ }^{162}$

During the 1890s, Africans in particular, were making considerable advances in a number of areas, including professional occupations such as teachers, lawyers, doctors, and the clergy. They were also making strides in occupational areas, such as bookkeeping and clerical work, that were the province of the middle class. Persons who were employed in these occupations tended to reside in the towns, particularly Georgetown.

The social progress made by the Africans and the subsequent growth of the middle class were beginning to engender some notable structural changes in the society. Merchants, particularly the Portuguese and the emergent African and colored middle class in the towns, were increasingly challenging the plantocracy. Political disenfranchisement became increasingly incompatible with the growing economic advances and political consciousness of urban interests. The incipient political class struggle also found support in some sections of the local press. The Daily Chronicle, caught up in the reformist zeal of the times, demanded:

Is anyone bold enough to stand up in this colony and say reform is not needed? In this democratic age when in every country of any importance the people have a choice in the election of their

${ }^{162}$ Kirke 1898, op. cit., pp. 45-46. 
governors, we here have not even the semblance of Representative Government...

We should not wonder if soon we shall be nicknamed across the water, "The stick-in-the-mud colony". Here we are with a government about as suitable to modern times as a wheelbarrow is for locomotion in comparison with the steam engine... and subjects of freedom-loving England, living under a "Despotism sweetened by sugar!"163

Widespread popular resentment against the plantocracy motivated Governor Irving to pressure the Home Government for reform of the constitution, and in 1891 a new constitution was approved following the passing of ordinance No. 1, "To alter and Amend the Political Constitution of this Colony." The ordinance abolished the College of Kiezers (the electoral college) and instituted direct elections for the unofficial members of the court of Policy. The court of Policy was retained, and the body enlarged with the addition of three appointed (official) and three elected (unofficial) members. Thus, the Colonial Government kept its majority through the casting vote of the governor. The newly elected members were to be drawn from Georgetown (two) and New Amsterdam (one). This distribution was designed to give greater representation to the mercantile and middle classes in the urban areas. But with five elective members coming from the rural constituencies, the planters were able to maintain their majority in the unofficial section of the Court of Policy. Qualification for election to the legislature was to be the ownership of not less than $\$ 7,500$

\footnotetext{
${ }^{16.3}$ Daily Chronicle, July 10, 1889.
} 
of immovable property besides land, and the franchise was lowered from $\$ 600$ to $\$ 480$ per annum. An executive council was constituted to assume the executive and administrative functions of the court of Policy. It was composed of the governor, a number of public officials, and the unofficial members appointed by the governor, all of whom were planters.

The first general election under the new constitution took place in January 1892, but the effects were negligible. The plantocracy firmly retained its hold on Guyana's political structure. The number of registered voters increased slightly from 1,973 in 1890 to 2,046 in 1891, and to 2,375 in 1892 following the enactment of the new constitution. ${ }^{164}$ The narrow representation favored the planters. However, when secret balloting was allowed in the 1897 elections, only one planter was returned to the court. In 1915, Africans constituted over 62 percent of the electorate, and Indians 6 percent. ${ }^{165}$ The political hegemony of the sugar planters had been broken, and white dominion over Guyanese political institutions was challenged by representatives of the African and colored middle class. Nevertheless, economic dependence on the sugar industry remained a steadfast reality.

${ }^{164}$ B. B. , $1890-1892$.

${ }^{165}$ Despres, L. 1967. Cultural Pluralism and Nationalist Politics in British Guiana. Chicago: Rand McNally, p. 39. 
Sugar's absence from the legislature was not quite the expected catastrophe for the plantocracy. The newly elected middle class were not antithetical to capital, or the sugar industry for that matter; but neither were they representatives of the working class, indeed, middle-class politicians bought into the idea that a healthy sugar industry was essential for the prosperity of the country. Oftentimes they strove to preserve or introduce legislation that was beneficial to sugar. For example, Patrick Dargan, a middle-class colored politician, scheduled a motion censuring the governor for tabling a bill that would give him the authority to remove immigrants from estates where he believed they were treated improperly. ${ }^{166}$ In 1894 , following another. price slump on the world market, the planters persuaded the legislature to absolve them of the responsibility to maintain the roads on the sugar estates, to reduce their share of the costs associated with medical facilities from one-half to one-third, to reduce their share of the costs of immigration from two-thirds to one-third, to extend their credit on the costs of water supply loans, as well as to pass some other minor legislation that was intended to provide assistance to the sugar industry. The costs of the subsidies were to be met by an increase in taxes on the general population. ${ }^{167}$

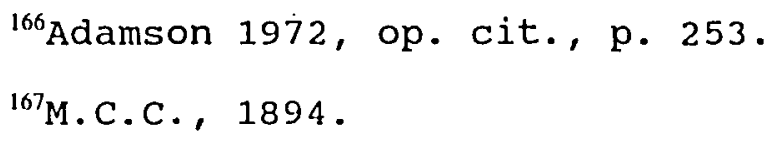


SUMMARY

Emancipation resulted in the evolution of small-scale villages along the Guyanese littoral. The formation of a free peasantry set in motion the village movement which flourished until the 1850s. Paradoxically, the end of the village movement came at a time when the sugar industry was witnessing a distinct revival of fortunes. The industry had adapted itself to the markets of the world system by means of amalgamation of estates, technological improvements, and reduction of wages through the introduction of indentured labor. Incorporation into the modern world system provided an additional stimulus to sugar production in the colony through the expansion of the metropolitan market for sugar. The cessation of indentured immigration, at the end of our period, cast a pall over the future of the colony. Indian indentured immigrants had bolstered and augmented the demographic structure since the abolition of slavery. By 1917, they had become the largest ethnic group, comprising over 43 percent of the population. ${ }^{168}$ Efforts to retain them in the colony had stimulated the rice industry, and had brought some measure of diversification to the country's economic structure. This in turn had fostered increasing residential and occupational segregation along racial lines - Indians overwhelmingly confined to the rural areas,

$$
{ }^{168} \text { B. B. , } 1917 .
$$


laboring on the sugar plantations and rice fields, and Africans dominating the occupational structure of the towns, and the gold fields in the interior.

The economic changes engendered by the development of the rice and gold industry, however, did not accompany profound spatial changes in the country's urban structure. The formation of a free peasantry, African and Indian, increased the number of proprietors and small farms at the expense of large estates, but it did not sever reliance on the metropole for manufactured goods and a trading partner. The country had been thoroughly peripheralized. As a result, very little effort was made to institute non-sugar infant industries in the urban areas, and to break Guyana's dependence on sugar as the mainstay of the economy. Surplus value needed for economic transformation was consigned to the core. Investment remained at a low level, public and infrastructural expenditures heavily favored the plantations, and only petty-commodity production and domestic, clerical, and administrative services provided alternatives to rural underemployment for the surplus population. So we find that although Georgetown and New Amsterdam exhibited signs of urban growth in the postemancipation era, they were doing so without an industrial and manufacturing base. Rather, they were essentially nodes, where the economic and political strength of the core 
and its representatives were concentrated to facilitate the chains of exploitation. 


\section{CHAPTER IV}

TWENTIETH CENTURY COLONIAL RULE 1917-1966

\section{GLOBAL LINKAGES}

This section illustrates the continuance of the colonial export economy, by charting the addition of bauxite and rice to the country's export market. It also demonstrates how the Second World War was instrumental in extending Guyana's linkage with North America through an increase in trade and the siting of U.S. naval and air bases in and around Georgetown. It examines the impact of these developments on the processes of urban change.

In 1917, the year indentured immigration was brought to a close, the Demerara Bauxite Company (Demba), a subsidiary of the Canadian-based transnational Aluminium Company of Canada (Alcan), established the bauxite industry in Guyana. Bauxite operations commenced very slowly. In 1917, only 2,037 tons of bauxite were exported, with all of the ore destined for North America.' Thereafter, exports fluctuated, and production actually stopped in 1922 as the

'B.B., 1917 . 
company sought to overcome some initial problems. ${ }^{2}$

Members of the sugar industry strongly opposed the introduction of bauxite mining, but the British Government was not swayed by the outcry. The government, worried because of its dependence on France for bauxite, welcomed the industry and clearly perceived the revolution that the aluminum industry was expected to engender. ${ }^{3}$

During World War $I$, the European sugar-beet industry, which had competed with tropical sugar production, was brought to an abrupt halt; as a result, the value of sugar exports from Guyana increased considerably. In 1913, prior to the outbreak of hostilities, the country exported 87,414 tons of sugar; however, by 1918 exports had climbed to 93,902 tons. ${ }^{4}$ The ending of the war abruptly halted the high prices that had prevailed during the conflict. High prices world-wide had stimulated sugar production in many parts of the globe, and this along with technological improvements in the industry created a glut of sugar on the world market. Consequently, sugar which was fetching over 50 pounds per ton in 1920 slumped to a little over 18 pounds per ton in 1921. Interestingly enough, there was no corresponding decline in the colony's export of sugar. Technical efficiency, particularly the introduction of

\footnotetext{
${ }^{2}$ B. B. , 1922 .

${ }^{3}$ M.C.C., Special Session, 1917 .

${ }^{4}$ Nath 1970, op. cit., p. 249.
} 
crystallizers which increased the recovery of sugar from the cane, contributed to almost a 33-percent increase in sugar exports between 1920 (83,765 tons) and 1921 (108,270 tons). ${ }^{5}$ During the war, rice was becoming a major agricultural concern when the governor stepped in to restrict exports in 1917. The governor, Sir wilfred collet, alarmed by the rise in exports, was concerned that the local market would be depleted of rice. Therefore, he introduced a licensing system, whereby all rice exports would require special permits issued only by him. The system was open to abuse, and within a short while a thriving black-market license trade had developed. The governor's response was swift and dramatic. He summarily placed an embargo on all rice exports from the latter part of 1918 until March 1919. Collet's curious measures are open to some serious questioning. Perhaps it would have been wiser to have encouraged farmers to increase the acreage under rice, rather than curtailing exports to solve the problem of food shortages at home. Furthermore, there is a lingering suspicion that the governor was restricting rice production in order to provide additional labor to sugar's depleted labor force. In any case, the effects of the embargo were to stifle the overseas trade and to return the captured west Indian market back to India and Burma.

Port traffic was seriously affected by the end of

${ }^{5}$ B. B. , $1920-1921$. 
indenture, the war, and collet's embargo. Shipping

activities at New Amsterdam's port, which were already at a perilously low level, came to a virtual standstill. In 1918, five ships (230 tons) entered the port, whilst 359 ships $(297,139$ tons) entered the Port of Georgetown; but two years later New Amsterdam was frequented by a mere three ships.(222 tons), and Georgetown by 137 (11,768 tons).6 Between 1921 and 1931, the sugar industry was faced with the peculiar problem of increasing exports fetching decreasing financial returns. The export of sugar from the colony in 1931 was 119,346 tons as compared with 98,958 tons, the average for the preceding ten years. ${ }^{7}$ Rice exports in 1931 amounted to 23,632 tons, as compared with 22,480 tons in 1930.8

Sugar and rice exports dominated Guyana's overseas trade in 1931, with a notable contribution from the bauxite industry. In total, the country exported $\$ 9,268,799$ worth of commodities, despite the economic depression throughout the world and the slump in market prices. ${ }^{9}$ There were appreciable, and in some cases quite remarkable, increases in the export figures of sugar, molasses, rice, and balata. Most of the colony's exports were shipped to Canada, the

$$
\begin{aligned}
& { }^{6} \text { B. B., } 1918-1920 . \\
& { }^{7} \text { B.B., } 1921-1931 . \\
& { }^{8} \text { B.B., } 1930-1931 . \\
& { }^{9} \text { B.B., } 1931 .
\end{aligned}
$$


United Kingdom, and elsewhere in the British empire. The United states and other foreign countries accounted for only 8.5 percent of the export trade. Virtually all of the shipping was handled by the Port of Georgetown. The port cleared 578 ships $(759,136$ tons), whilst New Amsterdam cleared only one (268 tons), and Springlands 393 (4,283 tons) .

The British, in 1928, introduced a Crown Colony form of government in Guyana, supposedly on the grounds that the old constitution was an impediment to development. Once the new constitution was in place, it was widely felt that Britain would invigorate economic development in the colony. However, in the following decade, little assistance was provided by the home government. Commenting on the colony's predicament, Webber concluded:

British Guiana cannot be said to have progressed in the 350 years since it was brought into touch with Europe. The indigenous people have practically disappeared. The new immigrant races have not yet commenced to increase and multiply. As a country whose exports amounted to close upon E1,000,000,000, her achievements have been disappointing. ${ }^{10}$

Furthermore, restrictions remained on the introduction of foreign capital into the country; the argument was that without restrictions the country would soon fall prey to foreign capitalists, who would overwhelm the domestic market just as they had done in Jamaica and elsewhere in the

\footnotetext{
${ }^{10}$ Webber 1931, op. cit., p. 363.
} 
Caribbean. The lack of development in Guyana convinced the local population that Britain had forsaken its only dependency on the South American mainland. This disillusionment and mistrust was compounded in 1939, when it was rumored that the British Government had agreed to settle German Jews in Guyana, and that it might indeed turn the colony over to the Germans in order to reach some accommodation with an expansionist Germany." The calls for attention would eventually be answered by the colonial office.

The Second World War extended Guyana's linkage with North America. Under an agreement with Great Britain, the Americans acquired a naval base in Georgetown and built an air base at Atkinson field, some 30 miles from the capital, up the Demerara River. Guyana was strategically important for the Americans, since it not only gave them a foothold on the South American continent, but also served as a refuelling site for American bombers en route to Africa. The war also stimulated the export of bauxite to Canada. Conversely, dependence on North America for food decreased, owing to difficulties experienced in shipping. Greater self-reliance was placed on home production, and as a result, Guyanese society begin to see the possibilities of indigenous development and what could be accomplished through partial delinking.

\footnotetext{
"Official Despatch, Lethem to Stanley, Oct. 8, 1943.
} 
Indigenous development meshed with the report of the West India Royal Commission in 1945, which urged a reversal of British colonial policy for Guyana and its British west Indian counterparts. The commission recommended that the colonies be regarded as economic entities in their own right and not simply appendages of the British market. ${ }^{12}$ The report was a harbinger of events to come. It set in motion the road to self-government, but economic independence and the realignment of the unequal relationship between Guyana and the core proved to be more intractable. The value of the country's overall trade reached a new record level of $\$ 47,553,571$ in 1943, as against $\$ 23,422,387$ in the pre-war year of $1938 .^{13}$ Higher prices of commodities and increased costs related to shipping and supply conditions were responsible for the increases in imports (which amounted to $\$ 24,368,598$ ) and exports (which totalled $\$ 23,184,973$ ). ${ }^{14}$ Trade was overwhelmingly oriented toward the United states, Canada, the United Kingdom, and to a lesser extent the British West Indies. Similarly, the range of exports was confined to the usual narrow range of commodities. No figures are available for bauxite exports, but 131,187 tons

${ }^{12}$ Report of the West India Royal Commission 1938-39. 1945. London: H.M.S.O.

\footnotetext{
${ }^{13} \mathrm{~B} . \mathrm{B}, 1938$ and 1943 .

${ }^{14}$ B. B., 1943 .
} 
of sugar and 17,180 tons of rice were exported in $1943 .^{15}$

The role of the Guyana sugar industry's link to the metropole cannot be over-emphasized. In 1938 sugar and its by-products, rum and molasses, contributed up to 65 percent of the value of the country's exports, with the actual export figures for sugar being about $\$ 7,500,000$ out of a total of $\$ 12,500,000 .{ }^{16}$ In 1946 the value of exports of the sugar industry had shot up to approximately $\$ 13,000,000$.

After World War II, British policy in Guyana was extremely conservative. The government sought to maintain Guyana as a plantation economy, although the indigenous population were appealing for diversification and industrialization. Exports of sugar in the post-World War II period steadily increased, from an average of 163,331 tons during 1946-50, to 222,545 tons during 1951-55, and to 273,179 tons during 1956-60.17

Rice exports, which had made rapid progress during the war, also continued to increase. During 1946-50 average annual exports were 23,197 tons; this amount increased to 37,300 tons during 1951-55, and to 43,300 tons during 1956$60 .{ }^{18}$ one interesting feature of rice exports was the

\footnotetext{
${ }^{15}$ Ibid.
}

${ }^{16} \mathrm{~B} . \mathrm{B} ., 1938$.

${ }^{17}$ Mandle, J. 1973. The Plantation Economy: Population and Economic Change in Guyana, 1838-1960. Philadelphia: Temple University Press, pp. 72-73.

${ }^{18}$ Ibid., p. 77 . 
opening of exports to Cuba once the People's Progressive Party (PPP) achieved power in 1957. In 1962 a boom in rice exports resulted in 90,000 tons going overseas, with over one-third destined for Cuba. This linkage, however, was severed in 1964 with the ascension of the People's National Congress (PNC) to office. Guyana immediately ceased exporting rice to Cuba. The expanding export market was stalled, and the industry has never fully recovered since that time. Exports were confined to Trinidad, Jamaica, Barbados, and the smaller British West Indian islands. Foreign trade was extremely highly concentrated. The United States, Canada, and Great Britain were Guyana's chief trading partners. In 1964, their overwhelming dominance of Guyana's foreign trade was evident. Over 75 percent of the country's exports and imports were associated with these three countries. ${ }^{19}$

overseas capital had been important for a long time in exploiting Guyanese resources. The sugar industry, the fulcrum of the colonial economy, had been brought about almost exclusively by foreign capital, and this was also true of bauxite. In the immediate post-war period, there was an increased flow of overseas capital. The sugar industry was greeted with an infusion of new capital to pursue a mechanization program. The mining industry,

${ }^{19}$ Guyana. 1964. Annual Report Relating to External Trade. Georgetown: Government Printery. 
particularly bauxite and gold, invested in new machinery. Also, the 1953-57 period witnessed an attempt by the British Government to increase spending related to development. However, overseas investment capital dried up during the Jagan years (1957-64); and it did not resume to any great extent until 1965, when Forbes Burnham assumed power.

\section{INDUSTRIAL STRUCTURE}

This section focuses on the emergence of bauxite and its domination of the industrial structure along with sugar and rice. It assesses the effects of the second World war on the country's major industries, and the imperial government's reluctance to encourage fledgling domestic manufacturing industries in the post-war period.

In 1910, the Director of Science and Agriculture reported the discovery of bauxite deposits to the combined Court:

I have the honour to report for the information of the Governor that I have examined specimens of rocks obtained from the low hills at christianburg and at Akyma, Demerara River, and have found them to largely consist of free alumina, 64 to $66 \%$, in the state of hydrate. ${ }^{20}$

Thereafter, a concession of 22,180 acres, consisting of some 20 abandoned plantations in the Christianburg Akyma district of the Demerara River, was granted to Demba to mine

\footnotetext{
${ }^{20}$ M.C.C., Second Special Session, 1917 .
} 
or quarry the bauxite. ${ }^{21}$ A new industry had been introduced, but the externally oriented economy reflected little structural change.

Guyana and the West Indies increased sugarcane production appreciably during 1914-18, to take advantage of the boom in prices that was set in motion by the ensuing shortages in Europe. The area under cane cultivation increased from 79,793 acres in 1914 to 89,970 acres in 1918 ; but following the war, cultivation contracted from 87,612 acres in 1919 to 63,420 acres in 1921.22 Also, after 1918 there was a slight decline in production, but during 1921 and 1931 the trend was once again upward. Production advances resulted from an expansion in sugarcane acreage, as well as increased efficiency in the industry that was brought about by more intensive use of fertilizers and improved varieties of sugarcane. Continued consolidation and amalgamation reduced the number of estates in the country by six to 38 , and the number of sugar factories to 20, in 1931.23 It was at this time that Bookers, a transnational company, commenced to purchase struggling plantations and to consolidate them. Through an aggressive acquisition program, the company began to solidify its hold on Guyana's sugar economy and to make inroads into other

\footnotetext{
${ }^{21}$ Ibid.

${ }^{22}$ B. B. , 1913/14-1921.

${ }^{23} \mathrm{~B} . \mathrm{B} ., 1921$ and 1931 .
} 
areas of the country's economic structure.

One important spatial effect of consolidation and amalgamation was the virtual elimination of the sugar industry in Essequibo, and the subsequent loss of population in that county. In 1921, Essequibo devoted 8,620 acres to sugarcane cultivation while registering a population of 55,276 ; but in 1931, only 890 acres of sugarcane were under cultivation, whilst the county's population had declined by nearly 11 percent to $49,830 .{ }^{24}$ The population structure and settlement pattern of the county were forever transformed.

Some workers displaced from the sugar industry in Essequibo moved into rice cultivation in the county. Between 1921 and 1931, the acreage under rice in Essequibo rose from 6,531 to $14,363.25$ other Essequibo sugar workers migrated to Berbice and Demerara to take up rice lands or to labor on the sugar estates in the other two counties. The shift into rice was initially hampered as a result of Governor Collet's export embargo, which adversely affected the country's overall rice production. Unable to export their crop, rice farmers were compelled to reduce the amount of land devoted to the staple. Consequently, the area under rice cultivation declined from 60,32 acres in 1918 to 54,400 acres in $1921 .{ }^{26}$ For most of the decade, Guyanese rice

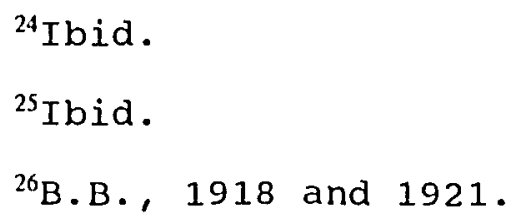


production continued its free-fall. In 1922 the number of acres cultivated had fallen to 49,073 , and the downward trend continued until 1925 when only 29,333 acres were under rice - a figure not seen since 1908, when the industry was still in its infancy. After 1925 rice production and acreage began to expand rapidly. By 1931, 73,647 acres were devoted to the cultivation of the staple - the first year in which the acreage under rice surpassed that of sugar. The total yield of 47,056 tons was derived from 191 rice mills dotted along the Guyana coastline. ${ }^{27}$ The progress noted in the rice industry occurred without much assistance from the government. Unlike sugar, rice was expected to develop on its own merits. Sugar was the colonial government's darling. This preference was exemplified in 1923, when the government attempted to reopen a sugar estate in Anna Regina, Essequibo. Although no sugar plantation, once abandoned, had ever been successfully restored, the government was induced to throw scarce monies into a rescue effort. Needless to say, the project was a resounding failure. Officials had hoped that a successful venture would rekindle sugar-growing on the Essequibo coast. Bauxite mining operations resumed after a temporary stoppage in 1922, and by 1925 production had reached a level of 174,999 tons. Thereafter, production fluctuated, declining to 165,423 tons in 1928 , rising to a new record of

\footnotetext{
${ }^{27}$ B. B. , $1921-1931$.
} 
185,151 tons in 1929, and falling again to 125,095 tons in $1931 . .^{28}$

The decade of the 1930s was a troubling one for Guyanese industries and those in the West Indies. The period was marked by industrial unrest and deteriorating economic conditions. In 1938, the British Government appointed a West Indian Royal Commission to investigate the sources of the problems and to make recommendations on how to alleviate the worsening conditions. The commission proposals were comprehensive in nature and touched upon just about every facet of Guyanese life. With respect to the country's industrial structure, the commissioners accepted the plantation economy and in fact suggested a greater role for the sugar industry in the country's economic future. World War II ushered in some significant developments in the country's industrial structure. The war proved to be a boon to the bauxite industry, which stepped up its production at an unprecedented pace. In 1937 bauxite production stood at 360,931 tons; by 1940 it was at 742,835 tons; and by 1946 it had risen to 1,120,015 tons, of which 1,095,129 tons came from the Linden region and 24,886 tons from the newly developed mine at Kwakwani, in Berbice. ${ }^{29}$

The war virtually made Guyana an island; disruptions in transportation and the shortage of imported goods

\footnotetext{
${ }^{28}$ Ibid.

${ }^{29}$ B.B., 1937; Legislative Council Paper No.11, 1948.
} 
encouraged local manufacturing and several minor industries. In 1943 there were 347 industrial establishments, the majority of which were located in Georgetown and the Demerara region (Table XII).

TABLE XII

INDUSTRIAL ESTABLISHMENTS 1943

Industry Georgetown Berbice Demerara Essequibo Total

\begin{tabular}{|c|c|c|c|c|c|}
\hline Aerated water & 13 & 7 & 6 & 2 & 28 \\
\hline Rice mills & 4 & 56 & 104 & 26 & 190 \\
\hline Dairy & 1 & 1 & - & - & 2 \\
\hline Sugar factories & 3 & 5 & 9 & - & 17 \\
\hline Confectionery & 6 & - & - & - & 6 \\
\hline Machine shops & 3 & 7 & 10 & - & 20 \\
\hline Sawmills & 7 & 9 & 7 & 14 & 37 \\
\hline \multicolumn{6}{|l|}{ Woodworking } \\
\hline factories & 7 & 4 & - & - & 11 \\
\hline Biscuit factories & 2 & - & - & - & 2 \\
\hline Steam bakeries & 2 & 2 & 10 & - & 14 \\
\hline $\begin{array}{l}\text { Cigarette factories } \\
\text { Edible oil }\end{array}$ & \multicolumn{4}{|c|}{ Edible oil } & 2 \\
\hline factories & 9 & - & 4 & - & 13 \\
\hline Match factories & - & - & 1 & - & 1 \\
\hline Lime oil factories & - & 1 & - & 1 & 2 \\
\hline Rum distillery & $=$ & 二 & $\underline{2}$ & $=$ & $\underline{2}$ \\
\hline Total & $\underline{59}$ & $\underline{92}$ & 153 & 43 & $\underline{347}$ \\
\hline
\end{tabular}

Source: Blue Book 1943 .

In 1943 there were 190 rice mills in Guyana. The war had stimulated the expansion of the industry just as it had done in 1914-18. Imports of rice from the Far East and India to the West Indies were curtailed, and Guyanese producers quickly flocked to fill the breach. However, unlike in 1914-18, the government did not place an export embargo on rice. A rice-marketing board was established, 
and it became the sole authorized purchaser and seller of rice for export and home consumption. The government made investments in irrigation and drainage projects. New varieties of seed were developed, and these combined with the other changes to increase fields and improve quality. Between 1938 and 1945, the area under rice increased from 49,159 acres to 63,015 acres. ${ }^{30}$ A "grow more food" campaign was also initiated to provide foodstuffs for the local market. Emphasis was placed on expanding the supply of ground provisions. Financial and technical aid, small-scale drainage and irrigation schemes, and other measures were provided. The success of the program was such that by 1945 the country was exporting plantains and cassavas. ${ }^{31}$

In contrast, the sugar industry struggled during the war. Shipping difficulties, labor shortages, and a lack of fertilizers reduced the sugar production from 196,502 tons in 1938 to 157,201 tons in $1945 .^{32}$ Fortunately for the sugar industry, the British Government stepped in to avert an impending disaster by agreeing to purchase all sugarcane produced in Guyana, despite the aforementioned shipping problems. The assistance was crucial for maintaining the cultivation of sugar in Guyana.

\footnotetext{
${ }^{30}$ Nath 1970, op. cit., p. 257 (statistical tables).

${ }^{31}$ Mandle 1973, op. cit., p. 115.

${ }^{32}$ Nath 1970, op. cit., p. 252 (statistical tables); Legislative Council Paper No. 11, 1948, p. 172.
} 
After the end of World War II, the British Government was faced with the choice of continuing the development of the country's industrial structure that had been so successful during the war or reverting to a system in which the plantation economy dominated. The administration chose the latter avenue. The encouragement given to the development of an independent peasantry through the "grow more food" campaign and assistance to rice farmers was rescinded because it was thought to be too expensive. The hegemony of the plantation economy would continue to be unchallenged, regardless of the implications of this kind of development policy on Guyana.

Very little was done to aid peasant production until after 1953, when the British Government, because of political considerations, attempted to win over rural voters. Unfortunately, much of the government's effort concentrated on social welfare expenditure, and this action did very little to alter the country's narrow industrial structure. The election of the PPP in 1957 resulted in a renewed emphasis on agricultural production. In particular, the PPP stressed improvement in rice production as a means of raising living standards, and the creation of the groundwork necessary for industrialization.

Between 1957 and 1964, when the PPP was in office, the percentage of capital expenditure devoted to agriculture increased from 33 percent in 1957 to 47 percent in 1964 . 
Much of the investment was spent on drainage and irrigation, land settlement, and other development schemes on the coastal strip. The Boerasierie, Tapakuma, Land of Canaan, and Mahaica-Mahaicony-Abary projects were all expected to bring hundreds of thousands of acres under production through the provision of elaborate water-control facilities. The acreage under rice cultivation in 1957 was 152,500 , in 1960 it reached 220,207 , and by 1964 it had increased to 311,417. Meanwhile, production increased from an annual output of 70,000 tons in the mid-1950s to 126,133 tons in 1960 and 164,000 tons prior to independence. ${ }^{33}$

Although sugar did not benefit directly from government expenditure under the PPP, the industry did manage to forge production increases during the 1957-64 period. The period witnessed new marketing arrangements with the core, which assured the industry's viability for some time. The industry also continued the trend to mechanize, amalgamate, and consolidate. After 1945, Bookers' monopoly of Guyana's sugar industry had intensified so that by 1960 the company was in control of 14 of the 19 estates in the country. In 1957, the production of sugar stood at 280,177 tons. It rose to 334,441 tons in 1960 before declining to 317,137 tons in 1963, and 309,000 tons in 1965. The declines in the early 1960s were the result of

\footnotetext{
${ }^{33}$ Jeffrey and Baber 1986, op. cit., p. 122; Annual Report Director of Agriculture, 1960
} 
internal turmoil which led to labor unrest in the industry. Bauxite mining, which had taken off during the war, continued to gain strength in the post-war era with the increasing demand for consumer durables in the core. By 1960, production amounted to $2,471,190$ tons.

Guyana's dependency on sugar, rice, and bauxite was evident when one considers that together their sectoral contribution to the Gross Domestic Product (GDP) was over 32 percent in 1960 (Table XIII). Sugar production alone accounted for 17.6 percent of the GDP. The poor contribution of the manufacturing sector, with only 5.2 percent of GDP, was partiy indicative of the government's lack of attention to the sector, but more importantly it can be seen as the result of Guyana's incorporation into the modern world system which created production and consumption patterns which did not reflect societal needs.

TABLE XIII

SELECTED SECTORAL CONTRIBUTION TO GDP 1960

Sector

Agriculture Sugar Rice

Mining

Bauxite

Manufacturing

Services
$1960(\%)$

24.2

$(17.6)$

( 5.3$)$

11.0

(9.5)

5.2

59.6

Source: Guyana Development Programme 1966-1972. 
The ouster of the PPP from office in 1964 resulted in the reduction of capital expenditure on agriculture in the two years prior to independence and in the consequent reduction of this sector's output to the GDP. In the first year of the post-PPP era, government investment in agriculture declined by 48 percent from that of the previous year. ${ }^{34}$ The new PNC regime, whose strength rested in Georgetown, New Amsterdam, and the mining town of Linden, was eager to repay its supporters in these areas. Change in the nation's industrial structure was in the offing, with all of its attendant spatial and socioeconomic implications.

\section{Labor supply}

This sub-section notes the importance of the labor supply as a function of demographic changes and the spatial distribution of population. It is concerned with the retrenchment of the labor force in sugar and the measures taken by the government to cope with the country's labor surplus.

The end of Indian indentured labor in 1917 meant that from now on increases in the country's labor supply would no longer be dependent upon immigration. Augmentation of the plantation economy's labor force would have to come about through natural increase, and this required significant

\footnotetext{
${ }^{34}$ Lakhan, V., D. Rawana and A. Lall. 1987. Resource Allocation in Agriculture: The Guyana Experience. Canadian Journal of Development Studies, p. 242 .
} 
changes in mortality and fertility rates. However, by the time indentured immigration ended, improvements had already begun to take place in the country's mortality and fertility rates. Furthermore, the unbalanced gender ratios of the previous era, which also accounted in part for the low rates of reproduction, were gradually becoming more equal. Confronted with a labor surplus in the colony, the planting fraternity feigned some resistance to the termination of immigration, but overall they felt assured that their labor needs would be satisfied.

With respect to the country's occupational structure, in 193174,603 persons, or slightly over 50 percent of the working population, were engaged in agriculture. Other numerically notable occupations included: commercial activities with 24,619 persons, domestics with 16,314 , mechanics and artisans with 15,617, and mining and quarrying with 5,058. There was little change in the occupational structure. Although bauxite was becoming an important component of the country's industrial structure, this was not reflected in the number of workers employed in the industry. Hence, the spatial distribution of population was little altered in 1931.

Initially, the sugar industry expressed some fears about the fledgling bauxite industry, but these concerns were quickly relinquished. Bauxite operations commenced very slowly, and owing to its capital-intensive nature, very 
few workers were employed by the industry. The growth of the rice industry, which planting interests encouraged, was another indication that sugar had solved its labor-supply problems. However, during the second World war sugar was once again faced with deteriorating labor supplies. Labor was increasingly attracted to the resurgence in the rice industry as well as the air and naval bases established by the Americans. The expansion in the bauxite industry also lured labor away from sugar. The country's occupational distribution in 1946 indicated that the sugar estates were the largest employers of labor. The rice industry was the next largest, and this was followed by vauxite, goid and diamonds, and timber. For all of bauxite's production increases, estimates indicated that this industry directly employed only 1,400 workers. ${ }^{35}$

In December 1946, out of a total resident working-age population of 45,917 on the estates, there were 11,735 persons engaged in the following private trades: shopkeepers, shop clerks, priests, tailors, goldsmiths, hucksters, housewives, bakers, butchers, domestics, barbers, milk-vendors, cartmen, chauffeurs, fishermen, seamstresses, teachers, and so on. ${ }^{36}$ It was generally believed that most of this group spent no time in the fields and factories of the estates. Thus, a paradoxical situation had developed on

\footnotetext{
${ }^{35}$ Annual Report 1946, p. 18.

${ }^{36} \mathrm{Leg}$ islative Council Paper No.11 1948, p. 311.
} 
the estates. They were sufficiently populated, yet they were suffering from a labor shortage and in many cases had to supplement their work forces with supplies of nonresident laborers.

From the above it is clear that not all of the former immigrants remained in agriculture once their contract with the estates had expired. Since the 1870s, a number of Chinese and Indians who had completed their indentureship were entering the retail trade as petty merchants in the rural areas. Discussing the in-roads made by Indians in the commercial field, Adamson notes that by 1882 there were 540 licersed Indian shopkeepers in the countryside and towns. ${ }^{37}$ The challenge of the Chinese on the Portuguese monopoly of the retail trade was no less formidable, and according to Moore:

By the 1890s. the chinese were well on their way to breaking the Portuguese stranglehold of the retail trade, and had established commercial bases in the Lombard street area of Georgetown and along Main street in New Amsterdam, quite apart from the numerous shops and stores scattered in the villages and plantations. ${ }^{38}$

Uncertain as to the reliability of their labor, the estates commenced a rapid mechanization program after the World War II period. Mechanization was particularly directed to field operations, where machinery replaced

\footnotetext{
${ }^{37}$ Adamson 1972, op. cit., p. 94.
}

${ }^{38}$ Moore, B. 1987. Race, Power, and Social Segmentation in Colonial Society. New York: Gordon \& Breach, p. 175. 
workers in land preparation, drainage and irrigation works, and transportation. Bookers, the country's leading owner of sugar estates, cited the following rationale for the mechanization of the industry:

There was a greatly increased demand for bauxite during the war and a great many skilled and semiskilled men gravitated to Mackenzie [Linden] (bauxite center in the interior of British Guiana). A good many skilled and unskilled men were required for the construction of Atkinson Field (airbase). The Mahaicony-Abary rice scheme required a great many shovelmen in the initial stages. There was a severe epidemic of malaria in 1943-44. Shortage of imported foods stimulated local food production. A shortage of consumer goods reduced the incentive to do more than a minimum of work. ${ }^{39}$

In 1953, 27 cane-field workers were needed to cultivate 100 acres; by 1960 , only 17 workers were required. In 1953, 24 factory workers were needed to produce 1,000 tons of sugar; by 1960 , only 13 persons were required. ${ }^{40}$ These productivity advances contributed to a reduction in the number of cane-field workers from 20,501 in 1953 to 16,001 in 1960, and to 13,262 in 1966 (Table XIV). In 1953 there were 5,804 factory workers, but this number declined to 4,478 in 1960 and to 3,663 in 1966 , the year of the country's independence. Production advances in the factory were the result of the introduction of new technologies such as continuous juice clarifiers and crystallizers, modernization of existing plants, and improved supervision pp. 41-42.

${ }^{39}$ Quoted in Mandle 1973, pp. 134-135.

${ }^{40} \mathrm{Nath}$, D. 1975. A History of Guyana. Norwood, (vol. 3), 
of mechanical and process operations. Overall, the labor force on the estates fell from 26,305 in 1953 to 16,925 in 1966.

TABLE XIV

SUGAR ESTATE EMPLOYMENT 1953-1966

$\begin{array}{lccc}\text { Year } & \text { Field Workers } & \text { Factory workers } & \text { Total } \\ 1953 & 20,501 & 5,804 & 26,305 \\ 1960 & 16,001 & 4,478 & 20,479 \\ 1966 & 13,262 & 3,663 & 16,925\end{array}$

Sources: Sukdeo 1975 pp. 238-240; Reports of the Statistical Bureau.

The retrenchment of the labor force in sugar was a serious blow to an economy that was highly dependent on a narrow range of industries. The situation was all the more alarming when one factors in the demographic changes that were occurring in the society at the time. Mortality declines and fertility increases were not only augmenting the country's overall population, but also introducing more and more persons into the labor force.

What became of this labor stream is an important element in Guyana's history of urbanization. The government hoped that rice would absorb the surplus labor, and that this absorption would in turn prevent rural out-migration. Drainage and irrigation works, land settlement schemes, and other projects were drawn up to open up new rice lands and to ease rural population pressures. In 1956 there were 23,000 people growing, harvesting, and processing rice on 
some 136,000 acres. By 1964, there were 35,000 people on 311,417 acres. However, the rice sector was unable to cope with the burgeoning population and to take up the slack created by sugar. Bauxite, although the industry was making great strides, was too capital-intensive to satisfy the labor problem. Nevertheless, bauxite's success did result in population movements to the mining town of Linden. A look at sectoral employment from 1946 to 1965 illustrates mining's poor contribution and the importance of agriculture and services (Table XV).

TABLE XV

SECTORAL DISTRIBUTION OF LABOR FORCE 1946-1965

$\begin{array}{lcccc} & \underline{1946} & \underline{1956} & \underline{1960} & \underline{1965} \\ \text { Labor force } & 147,481 & 164,600 & 174,997 & 193,048 \\ \text { Employed } & 143,750 & 135,000 & 161,202 & 165,912 \\ \text { Industries } & \% & \% & \% & \% \\ \quad \text { Agriculture } & 42.0 & 42.5 & 37.1 & 34.9 \\ \text { Mining } & 2.8 & 1.3 & 3.8 & 3.1 \\ \text { Manufacturing } & 16.0 & 12.9 & 16.3 & 16.2 \\ \text { Services } & 38.7 & 43.3 & 42.8 & 45.8 \\ \text { None } & 0.5 & - & - & - \\ \text { Unemployment } & 2.6 & 21.9 & 8.5 & 16.4\end{array}$

Sources: Jameson 1980; Manpower Survey 1965.

The data illustrate the importance, and at the same time the decline, of agricultural employment over the period. Employment in manufacturing remained relatively static, and its implications for the urban areas were obvious. Furthermore, the weakness of manufacturing employment, which is usually an urban phenomenon, was all 
the greater when one considers that the figures included employment in sugar factories and rice mills, which were located in the countryside. Mining also held relatively steady through the period, thereby supporting the claim that the sector was very much a capital-intensive one. The only sector which showed any real growth was services, and much of this growth was due to the increase in public-service employment, especially after 1964 when the PNC began to reward its urban supporters with government jobs.

\section{DEMOGRAPHY}

This section highlights the pattern of population and area growth throughout the country. It continues to emphasize the demographic changes taking place in Georgetown and New Amsterdam, and it touches on the emergence of the bauxite-mining town of Linden.

According to the Census of 1921, Guyana's population stood at 297,691 , or an increase of barely 1,650 persons over that of the previous census in 1911 (Table XVI). The .56-percent increase reflected a miserly annual population growth rate of 1 percent over the 10-year intercensal period.

In 1918, the country was troubled by a severe influenza epidemic which severely depleted the laboring population. The death rate for the year was an astonishing 
TABLE XVI

POPULATION DISTRIBUTION

Year Guyana Georgetown $:$ New Amsterdam $\%$ Urban

1921297,691

1931310,933

1946375,701

$\begin{array}{rrr}59,624 & 20.0 & 7,651 \\ 69,663 & 22.4 & 8,002 \\ 94,036 & 25.0 & 9,567 \\ 148,391 & 26.5 & 14,053\end{array}$

$2.6 \quad 67,275 \quad 22.6$

$2.6 \quad 77,665 \quad 25.0$

$2.5103,602 \quad 27.6$

1960560,330

$148,391 \quad 26.5 \quad 14,053$

$2.5162,444 \quad 29.0$

Sources: Census 1921-1960; Gyanchand 1964 .

40.6 per 1,000 of the population. ${ }^{41}$ In addition to high mortality rates, much of the low level of population growth must be attributed to the high levels of Indian emigration following the curtailment of the indenture system in 1917 . Between 1911 and 1921, over 15,759 Indians departed the colony. In 1920, three years after indenture was ended, 2,468 persons returned to India. Indeed, during the decade the Indian population as a group decreased by 1.25 percent, and their overall contribution to the country's demographic composition declined from 41.0 percent to 40.7 percent. ${ }^{42}$

In the urban areas the population increased from 66,181 in 1911 to 67,275 in 1921 , or by 1.65 percent, whilst the population in the rural areas declined by 1.13

percent. ${ }^{43}$ However, it would be erroneous to assume that the lower number of rural dwellers was the result of a movement to Georgetown and New Amsterdam. Rather, the lower

\footnotetext{
${ }^{41}$ B. B. , 1918 .

${ }^{42}$ Census 1921.

${ }^{43}$ Ibid.
} 
rural figures more likely stem from the exodus of indentured workers back to India.

Georgetown, with an increase of 2,047 persons (or 3.5 percent) over the decennium, wholly accounted for the increase in urbanization. The city was now 7.8 times the size of New Amsterdam, which once again had suffered a loss of population.

The post-war depression had effected the dissolution of a number of the smaller sugar plantations in the vicinity of the town. These relatively small-scale operations were dependent, in part, on labor resident in the town; and following the demise of these operations, the number of New Amsterdam's agricultural laborers decreased to 251 persons in 1921.44 Businesses were also adversely affected, and some of these were forced into liquidation. The failed sugar plantations, and a few of the liquidated businesses, were bought out by Bookers. Unlike the labor-intensive smaller plantations, Bookers' plantations were larger and highly mechanized, they did not depend quite so heavily on town labor, and they were not dependent on the town for various services.

New Amsterdam's downward spiral was all the more noteworthy when one considers that Berbice was the fastestgrowing region, with a 4-percent population growth rate over the census period. Most of the county's growth can be

\footnotetext{
"Ibid.
} 
credited to migration of ex-sugar workers from Demerara and Essequibo. These migrants were primarily interested in peasant-rice cultivation, and therefore they sidestepped New Amsterdam and headed for the corentyne coast. In addition, Indians were restricted from employment opportunities in the urban areas. Discriminatory practices excluded them from jobs in the private and public sectors, and this discrimination served to reinforce their paltry representation in the population composition of the two towns. In 1921, Indians comprised 11 percent $(6,418)$ of Georgetown's population and 15 percent $(1,294)$ of New Amsterdam's. Since the census of 1911, the Indian population had increased only by 400 in Georgetown and by two (2) in New Amsterdam, whilst their share of the population distribution had increased by 1 percent in Georgetown and had remained the same in New Amsterdam. ${ }^{45}$ Thus, the racial division of labor resulted in a population distribution which confined Indians to the countryside, and African-descended peoples to the urban areas and the fledgling mining operation in the upper Demerara River. Increased bauxite production in the 1920 s resulted in larger numbers of African-Guyanese migrating from Georgetown and the villages to the Demba company town of Linden, formerly Mackenzie. At the same time, the mining of diamonds had become significant and this success had

\footnotetext{
${ }^{45}$ Ibid.
} 
attracted Africans into the interior, in particular into the Mazaruni region. For the most part, it was the African male who ventured into the interior, to prospect for several months before returning home. African women remained in the villages and towns, but in time they too followed their partners into the hinterland, and microcommunities were established in a number of areas.

In the course of the intercensal period of 1921-31, the population of Guyana witnessed a net increase of 13,242 persons, or 4.4 percent, to stand at $310,933 .{ }^{46}$ During the decade, emigrants exceeded immigrants by 2,101 , as compared with an excess of arrivals over departures by 11,152 persons between 1911 and 1921. While the birth rate of 31.9 was not particularly high, the death rate of 264 was the lowest recorded since the first census of 1841 .

The gender ratios of earlier censuses revealed that the population was a male-dominated one. Slavery and indentured immigration had skewed gender ratios, mainly because of the male labor requirements of the plantation economy. However, the ending of labor importation through indentured immigration, and male emigration during 1921-31 caused a steady decline in the gender ratio, and served to normalize demographic conditions (Table XVII).

Over the period (1921-1931) there was a noticeable upturn in the rate of urbanization (Table XVI). The number

\footnotetext{
${ }^{46}$ Census 1931.
} 
TABLE XVII

GENDER RATIO 1881-1931

$\begin{array}{lcccc}\text { Year } & \text { Male } & \text { Female } & \text { Total } & \text { Gender Ratio } \\ 1881 & 140,134 & 112,052 & 252,186 & 1.25 \\ 1891 & 151,759 & 126,569 & 278,328 & 1.20 \\ 1911 & 153,381 & 142,324 & 296,041 & 1.08 \\ 1921 & 151,261 & 146,430 & 297,691 & 1.03 \\ 1931 & 155,381 & 155,552 & 310,933 & 1.00\end{array}$

Source: Census 1881-1931.

of persons residing in the urban areas increased from 67,275 in 1921 to 77,665 , or by 5.7 percent, whilst those in the rural areas increased from 230,416 to 241,032 , or 4.6 percent. Within the urban areas, the population of Georgetown was 69,663 , as compared with 59,624 persons at the previous census, representing an increase of 16.8 percent during the period. Georgetown accolinted for 22.4 percent of the total population of the colony and 87 percent of the urban population. The capital was 8.7 times the size of New Amsterdạm. New Amsterdam's population was 8,002, or 2.6 percent of the total population of the country. This was an increase of 351 , or 4.6 percent, of the total population of the town in 1921 .

In the capital, the poorer southern wards registered the largest gains over the decade. Albouystown led the way with an increase of 2,309 persons, or 56.9 percent, and was followed by Werk-en-Rust with an increase of 1,051 persons, or 14 percent. Of the suburban areas of the city, Kitty's 
increase of 2,430 , or 57 percent, was the most noteworthy ${ }^{47}$ Between 1921-1931 there were increases in all of the ethnic groups except Europeans, Portuguese, and Amerindians. The largest numerical increase occurred among the Africans $(7,034$, or 6 percent), Indians $(5,602$, or 4.5 percent), and coloreds $(3,213$, or 10.5 percent $)$. Of the groups that declined, Europeans decreased by 35.4 percent to 2,127 , Portuguese by 6 percent to 8,612 , and Amerindians by 8.8 percent to 8,348 . Indians were the largest single racial group, with 130,540 persons; however, they were closely followed by 124,203 Africans, who when combined with the colored group surpassed the Indians. These three groups (Indians, Africans, and coloreds) when taken together formed 81.9 percent of the country's population. Indians were in the majority on the Corentyne Coast, East Coast Berbice, West Coast Demerara, and the islands in the Essequibo. Africans predominated in New Amsterdam, West Coast Berbice, and Georgetown, and up the Essequibo, Potaro, Cuyuni, Mazaruni, and Puruni Rivers. Chinese, Europeans, and Portuguese were clustered for the most part in Georgetown and New Amsterdam. ${ }^{48}$

In 1938 it was reported by the Moyne Commission that:

...the increase in rural under-employment and the comparatively greater urban wage-increases have intensified the drift to the towns which is a

\footnotetext{
${ }^{47}$ Ibid.

${ }^{48}$ Ibid.
} 
characteristic of the West Indies...

This tendency is vicious in its long term effect. There is no economic possibility for large agricultural populations to establish themselves in conditions sufficiently stable to enable them to form and perpetuate a healthy community. Further, each influx dilutes the amount of employment available for the original inhabitants and drags down standards of life for others than the newcomers themselves. ${ }^{49}$

The description is largely reminiscent of conditions in Georgetown in the middle of the nineteenth century. The growth of the population of the city, including its suburbs, between 1931 and 1938 was due mainly to migration from the rural areas and to a lesser degree to returning migrants from the interior.

Between the intercensal period 1931 and 1946, there was an enumerated increase of 64,768 persons (TABLE XVI). The annual rate of growth during the period was 1.3 percent and was the result of declining mortality rates as well as rising fertility levels, particularly in the Indian group. ${ }^{50}$

With 27.6 percent of the population residing in urban areas in 1946, the census alluded to the fact that the country was becoming more urbanized. Between 1931 and 1946 the urban population increased by 33.4 percent to 103,602 , although the rate of growth was unevenly shared by Georgetown and New Amsterdam. In Georgetown, the number of residents increased by 35 percent, from 69,663 to 94,035,

\footnotetext{
${ }^{49}$ Report of the West India Royal Commission, 1945, p. 33 .

${ }^{50}$ Census 1946 .
} 
while those in New Amsterdam increased by 19.6 percent, from 8,002 to 9,567 . The divergence in growth between the two towns was attributed, in part, to employment opportunities on the American bases in the Georgetown area. Work on the bases and the take-off of the bauxite industry led to the development of a small migration stream to Georgetown.

In the course of the intercensal period of 1946-60, Guyana's population increased by 67 percent to 560,330 . with improvements in curative and preventive medicine, particularly the eradication of malaria from the coastal areas, the population grew by 13,192 , or 2.9 percent, per annum. The birth rate rose from an average of 39.4 per thousand in 1946 to 43.3 per thousand in 1960, whilst the death rate fell from 14.4 to 10.4 per thousand. ${ }^{51}$ The decline in the death rate was most noticeable with respect to the infant mortality rate, which dropped from 83.0 to 63.6 per thousand in the corresponding period. ${ }^{52}$

The rural Indian population were the main beneficiaries of the coastal malaria eradication program, for the sites of the anopheles mosquito were mostly to be found in the rural areas where sugar and rice were cultivated. Between 1936 and 1960, the Indian death rate fell from 23.3 to 9.7 per thousand, whilst the African death

\footnotetext{
${ }^{51}$ Gyanchand. 1964. Annexure to the Report of the Three Year Plan 1964-65-66 for British Guiana, Volume of Basic Statistics, (Table IV) p. 17; Census 1946 and 1960.

${ }^{52}$ Ibid.
} 
rate fell from 21.0 to 12.5 per thousand (Table XVIII).

TABLE XVIII

DEATH RATES OF INDIANS AND AFRICANS 1936-1960

Years Indian African

$\begin{array}{rrr}1936-1940 & 23.3 & 21.0 \\ 1941-1945 & 19.6 & 21.1 \\ 1946-1950 & 13.9 & 16.7 \\ 1951-1955 & 15.0 & 12.1 \\ 1956-1960 & 9.7 & 12.5\end{array}$

Source: Gyanchand 1964, Table IV, pp. 19-22.

To be sure, the eradication of malaria was not the sole reason for the divergence in death rates between the two groups, and by extension between urban and rural areas. Sugar estate workers were also the recipients of better health care in the 1930s and an extra-nuclear housing program which relocated Indians from the squalid and overcrowded ranges to newer housing along the main road. The housing program was accelerated following the investigation by the 1949 Venn Commission, which was very critical of housing conditions on the estates:

We inspected many of these ranges. In quite a number the corrugated iron roofs were lacking and the fabric of the buildings was in a general state of decay. In numerous instances temporary sheets and awnings had been fixed over the beds to keep off the rain. They had mud floors and consequently with the rain dropping from the roofs these were made slippery and dangerous; in many cases we found bags laid over the floor to prevent slipping. They are built without ary plan on low-lying uneven ground. There are few, if any, proper footpaths and in rainy weather communication is difficult. The common latrines, often built over a drainage trench, are frequently in a bad state of repair 
with little privacy. ${ }^{53}$

Indians were also primarily responsible for the increase in the birth rate. From 1936 to 1960, the Indian birth rate increased from 38.0 to 51.1 per thousand whilst the birth rate among the African population increased more modestly from 26.9 to 36.9 (Table XIX).

TABLE XIX

BIRTH RATES OF INDIANS AND AFRICANS 1936-1960

\section{Years}

$1936-1940$

1941-1945

$1946-1950$

$1951-1955$

$1956-1960$

\section{Indian}

38.0

40.6

46.1

49.3

51.1
African

26.9

28.4

33.4

35.3

36.9

Source: Gyanchand 1964, Table IV, pp. 19-22.

Despite the growth of the Indian population, only 22 percent of the population in the two main urban centers were Indian, in 1960. The African and colored population, with roughly 70 percent of the urban population, dominated the towns. Africans, who comprised 32.8 percent of the country's population, accounted for 48.5 percent of Georgetown's population and 53.9 percent of New Amsterdam's. Indians, who made up 47.8 percent of the population, formed 21.9 percent of the population in Georgetown and 24.7 in New Amsterdam. In the rural areas the situation was reversed,

${ }^{53}$ Colonial office. 1949. Report of a Commission of Inguiry into the Sugar Industry of British Guiana. London: H.M.S.O., p. 120 . 
with Indians in the majority. ${ }^{54}$

Indians, however, were inexorably moving into the urban areas. Migration to the towns stemmed largely from push components, although pull components could not be discounted. The most noticeable push was population pressure, of which the rural manifestations were unemployment and land shortages. Land shortage was connected to the pattern of land ownership as well as to population growth and distribution, since a large number of the coastal lands were dominated by the sugar companies and large-land owners. Land hoarding and shortages of land existed alongside each other, as they had since emancipation, with the former ensuring the latter. The outcome of this induced population pressure was that few peasant farmers could buy or rent a suitable amount of land on which to support themselves and their families without recourse to additional wage labor. In many cases the problem was compounded by seasonal unemployment on the sugar estates. Furthermore, the wages of casual agricultural laborers were usually so low as to be practically unacceptable. Among pull components, unemployment rates in the urban areas were now lower than those in the countryside, and this difference may have been an additional

\footnotetext{
${ }^{54}$ Census 1960.
} 
spur to migration. ${ }^{55}$

of the population enumerated in 1960, a total of 162,444, or 29 percent, were living in Georgetown and New Amsterdam. A good deal of the increase in urbanization since the 1946 census can be attributed to internal migration (Table XVI). According to the 1960 census, 16.7 percent of Georgetown's population were migrants who had arrived during the intercensal period. Of the 24,782 migrants to the capital, 13,906 (or 56 percent) were females. ${ }^{56}$ The higher female urban migration rate can be explained to some degree by the increasing number of women entering the labor force in Georgetown. In New Amsterdam the influx of migrants was even more noticeable. The growth of the bauxite industry at Kwakwani and the construction of Everton, upriver from New Amsterdam, as a bauxite transshipment center attracted 4,478 migrants, or 31.9 percent, of the town's population between 1946 and 1960 . The 1960 census also revealed that the occupational structures of the urban areas were still dependent on services as the most important source of employment. ${ }^{57}$ Fuelled by internal migration, the rate of urban growth increased by 72.7 percent from 1946 to 1960 .

${ }^{55}$ Francis, 0 . 1966. Report on Survey of Manpower Requirements in the Labour Force, British Guiana. Georgetown: Government of Guyana.

${ }^{56}$ Census 1960 .

${ }^{57}$ Census 1946 and 1960 . 
Georgetown increased by 57.8 percent and New Amsterdam by 46.9 percent. The capital was now more than ten-and-a-half times the size of New Amsterdam, whereas it had been only eight times as large in 1921. Georgetown's urban growth was characterized by rapid suburbanization and in-filling in the city itself. The tremendous suburban expansion resulted for the first time in more people residing in the suburbs $(75,427)$ than in the central city $(72,694)$. In the northeast, the upper- and middle-income suburbs of Bel Air, Newtown, Campbellville, Kitty, and Subryanville all posted substantial gains, and the same was true for the workingclass suburbs of La Penitence, Ruimveldt, Meadow BankHouston, Agricola, and Lodge Village. Ruimveldt, with a population of 16,040 , was the largest of the suburbs and was closely followed by Kitty, whose population amounted to $15,042.58$

A further redistribution of the population occurred during the racial disturbances of 1962-64. Indians and Africans fled from villages in which they were in the minority to take up residence with members of their own ethnic groups. Many Indians who were forced out of Linden and the African-dominated villages of West Coast Demerara initiated squatter settlements, such as Mon Repos, on unused sugar estate lands along the main road and the coast.

${ }^{58}$ Census 1960. 
INFRASTRUCTURE AND URBAN DEVELOPMENT

The following section probes the role of the central government in influencing urban development by examining the size and direction of its contributions to housing, roads, sewage, water supply, health facilities, and other infrastructural programs. It also assesses the 1945 Colonial Development Welfare Act; development plans for 1947-56, 1954-1955, 1955-1960, and 1960-1964; the Town and Country Planning Ordinance of 1946; and the Greater Georgetown Plan of 1951.

The slump in the sugar and rice industries, following the cessation of hostilities in 1918, was coeval to the decline in the country's growth and development. The British Government had used the war as an excuse to curtail development throughout the country. In 1917, the governor, Sir Wilfred collet, told the Combined court that it was impossible for the colony to consider hinterland development, but after the war he promised "a revival of industries in that neighborhood."59 Likewise, a petition to have the Corentyne road extended from skeldon to Crabwood Creek was denied "because of expenditure on the war."60 Similar situations were evident in Georgetown and New Amsterdam. Municipal infrastructural subventions from the

\footnotetext{
${ }^{59}$ M.C.C., Nov. 8, 1917.

${ }^{6}$ M.C.C., 1918 .
} 
Colonial Government were exceedingly difficult to come by during the latter part of the war. In 1918, the Georgetown Town Council implored the government to increase the amount on the estimate to $\$ 6,000$ for roads in the city, which were rapidly deteriorating at this time. ${ }^{61}$ However, the government steadfastly refused. The governor argued that since the Colonial Government was a sizeable rate-payer in the city, it was up to the Town council to manage its own affairs.

I do not see the slightest justification for the contribution of $\$ 6,000$, seeing that the government pays rates which amount to upwards of $\$ 30,000 .^{62}$

It was not until 1921, prior to the visit of the Prince of Wales, that the government stepped in to rectify the problem. Brickdam, a major thoroughfare, was macadamized, and some of the more commonly travelled streets were repaired. Conversely, some projects which were thought to be essential to the war effort were curtailed following the signing of the armistice. A food factory to make flour out of rice, maize, and ground provisions, planned for Georgetown, was no longer thought to be necessary since the war was over. ${ }^{63}$ Plans made in 1917 to harness the power

\author{
${ }^{61}$ Ibid. \\ ${ }^{62}$ Ibid. \\ ${ }^{63}$ M.C.C., Nov. 20, 1918 .
}


potential of the mighty Kaieteur Falls ${ }^{64}$ in order to process bauxite into aluminum were similarly dashed. ${ }^{65}$ Instead, Guyana's bauxite was destined for North America, where the most lucrative value-added stage of the processing would be accomplished.

In the interior, the number of roads and trails grew as a result of increased mining activity, but here too, the government did little to develop the transportation network. On the coast, the government did step in on January 1, 1922, to assume full control of the Demerara Railway. Two years later, in an effort to "beautify" the city, the new owners evicted 717 persons who had been living alongside the railway line in North Cummingsburg. ${ }^{66}$ Residents of the city suffered a further setback in 1930, when the tramway service operated by the Demerara Electric Company Limited was terminated. ${ }^{67}$ Laborers had depended on the trams to take them to work on the outlying plantations on the East Bank. On July 2, 1923, New Amsterdam suffered its most severe fire when the entire length of Pitt street, the main retailing center, was burnt to the ground. The fire spurred a renewal of building activity in the town, but the effort

${ }^{64}$ Situated on the Potaro River, Kaieteur is one of the highest waterfalls in the world. With a single drop of 741 feet, it is nearly five times as high as the Niagara Falls.

\footnotetext{
${ }^{65}$ C.C., Second Special Session, 1917.

${ }^{66} \mathrm{Legislative}$ Council Paper No. 13, 1931.

${ }^{67}$ B. B. , 1930 .
} 
failed to inject any meaningful long-term development.

For some time the mortality rate in Georgetown had been higher than those in the rest of the country. The authorities attributed the problem primarily to a lack of adequate sewage-disposal facilities in the city. At times, parts of the city were saturated with raw sewage from poorly maintained and inadequate cesspits. Therefore, it was some relief to urbanites when the Georgetown Sewerage Scheme was undertaken in 1924. By 1930, the entire capital was served by a modern sewage system.

The completion of the sewage works caused some consternation in Georgetown, for it came at a time when unemployment in the city was rather severe. As part of the public works program, the Georgetown sewerage Scheme had been a major employer of labor. Now that the project was at an end, and the sugar, mining, and rice industries were in the midst of a depression, there was widespread unemployment in the city. The depression in the mining industry was particularly visible, since it resulted in large numbers of unemployed pork-knockers descending on the city. To relieve Georgetown of this surfeit of labor, the legislature made a number of proposals. These included the granting of free passages from Georgetown to Bartica, Morawhanna, and Mabaruma; reconditioning of roads in the neighborhood of Georgetown; an individual colonization scheme in the North West District; town planning and road building at Bel Air 
Park; and irrigation of the Corentyne from Bloomfield to Philippi. ${ }^{68}$

Most of the proposals were shelved; however, the townplanning and road-building scheme at Bel Air Park warrants some discussion. The purpose of the plan was foremost to provide unemployment relief for the city, and secondly, to curb speculation and provide orderly development. Bel Air Park, a large race course adjacent to the municipal boundaries of Georgetown, was an ideal site. The land was much cheaper than those in the city, and its geographical position suggested that annexation would be a matter of course. According to the proposers of the plan:

...Bel Air Park should be under some form of public ownership, more especially to avoid the defects of private ownership as represented in the contiguous township of Newtown...

We consider that immediately on acquiring of the property, east and west roads should be planned and constructed, thus creating direct communication with Campbellville, a growing township, and also providing alternate and desirable approaches to the East coast Road which is now reached only through the main road of Kitty...

The example of Campbellville established that fact that persons are now ready to erect houses contiguous to Georgetown, since no less than 240 of these have been constructed at campbellville, where builders have to be content with the unsatisfactory status of lease holders. ${ }^{69}$

Unfortunately, the plan was subsequently withdrawn on the grounds that the cost of incorporating Bel Air Park was

${ }^{68}$ Legislative Council Paper No.5. 1930. Report of the Economic Investigation Committee. Georgetown: Argosy.

${ }^{69}$ Ibid. 
prohibitive.

In 1931, the British Government did provide a grant of $\$ 696,491$ for unemployment relief in Guyana; but this grant hardly benefitted the towns, since the money was expended in the following manner:

Roads Sea Defenses Buiidings Advances Sugar Estates Development of Country Areas Improvements of New Amsterdam

Total

$$
\begin{array}{r}
\$ 257,142 \\
140,703 \\
29,275 \\
187,197 \\
81,174 \\
1,000 \\
\hline
\end{array}
$$

$$
\$ 696,49.1^{70}
$$

The lack of expenditure on improvements in the towns was a cause of embarrassment for the governor, Sir Edward Denham. He apologized to town dwellers in the Legislative Council, and at the same time he tried to assure residents of New Amsterdam that the sum of $\$ 1,000$ "spent on the bonification of the frontal lands of New Amsterdam" augured "well for the improvement of sanitary and health conditions" of the town. ${ }^{71}$

New Amsterdam, however, was allowed to annex the Winkle and Vryheid. The town felt that the administration of these two adjacent communities should be administered by

${ }^{70}$ Legislative Council, Jan. 12,1932 .

${ }^{71}$ Ibid. 
the municipality was in the town's best interest. ${ }^{72}$ since both communities were relatively small, they did not constitute a major extension of the town's boundaries and population.

Denham attempted to gain the favor of Georgetown residents by apportioning 50 percent of the cost of the Georgetown Sewerage Scheme on taxpayers throughout the country. Denham, himself a resident of the capital, provided a clear case of "urban bias" when he argued:

Undoubtedly it is to the advantage of every tax payer in British Guiana, that Georgetown, the capital and port of the colony, should be in possession of a sewerage scheme, ensuring healthy conditions in this important centre. This is the concern of everybody - even though it may only be the inhabitants of Georgetown who have received the direct benefit therefrom. Such being the case, it may, I think be reasonably argued that the property owners having linked up with the scheme and placed their houses in order, the colony may well be responsible for the cost of the main drainage part of the scheme. That is to say, that in the opinion of government an adjustment on the basis of $50 / 50$ would be equitable. ${ }^{13}$

The question of a pure water supply from artesian wells was also reopened in 1931. Up to 1924, nearly 100 wells had been sunk along the coastal plain. The wells on the whole had been successful in ensuring a constant supply of potable water for domestic services. Therefore, it was

${ }^{72}$ Legislative Council Paper No.7. 1931. Report of the Committee on Local Government Administration. Georgetown: Argosy .

${ }^{73}$ Ibid. 
not surprising that the program was extended in $1931 .{ }^{74} \mathrm{BY}$ 1938, 69 artesian wells had been completed, providing access to the entire urban population. Improvements in the water supply were not confined to the towns, but were also made on the sugar estates and the villages.

The artesian well program greatly improved the general health of the population, who were spared the effects of a number of gastric diseases, and to some extent problems associated with malaria. Expenditure on health care escalated following the end of indenture. In particular, investment in public health proceeded much more rapidly on the sugar estates than elsewhere in the colony. The government and planters clearly understood that, without improvements in health care, the cost of labor would be prohibitive; therefore, it was in their best interest to invest in health care. In 1918, government expenditure on hospitals and health care amounted to $\$ 54,739$, by 1942 it had risen to $\$ 946,000$, and by 1946 it had reached $\$ 1,659,000$. The increase in health expenditure during the war years was attributed partly to the influx of British service personnel in Guyana. Having newly arrived in the tropics, soldiers were susceptible to malaria, enteritis, typhoid, bronchitis, and tuberculosis; in addition on completing their tours of duty, they were liable to carry

\footnotetext{
${ }^{74}$ Legislative Council Paper No.15. 1931. Report of the Committee Appointed to Enquire into the Sinking of Wells under the Pure water Supply Scheme. Georgetown: Argosy.
} 
these diseases back to the core. ${ }^{75}$

In 1945, over 12 percent of the country's revenue was being allocated towards health care. Despite these impressive sums, conditions on the estates were more favorable than those in the villages or in Georgetown and New Amsterdam. The hospitals on the estates were the private property of the individual sugar companies. They were required under the Immigration ordinance, but their upkeep was no longer compulsory since immigration had ended in 1917. Nevertheless, in 1945, there were 21 hospitals with 1,409 beds on the sugar estates. This was equal to one bed for every 51 persons. In comparison, the city of Georgetown maintained 666 beds, or one for every 141 persons, and New Amsterdam 170 beds, or one for every 56 persons. Furthermore, it must be remembered that the two urban areas also served their respective counties, and as a result the ratio of beds to population was a good deal higher. In Georgetown the ratio was $1: 332$, and in New Amsterdam 1:568. Therefore, it is not surprising that the percentage of beds occupied in estate hospitals hovered around 40 percent, whilst government hospitals in the towns were badly overcrowded. ${ }^{76}$ The commissioners of a report on the sugar industry in 1949 underscored the health-care

${ }^{75}$ Odle, M. 1976. The Evolution of Public Expenditure: The Case of a Structurally Dependent Economy. Kingston: University of West Indies, p. 59.

${ }^{76}$ Legislative Council Paper No.11, 1948, op. cit. 
problem:

It startled us to find that, outside the estates, no provision exists at the moment for hospital treatment in the villages and rural districts. Urgent cases are sent to the hospitals at Georgetown or New Amsterdam, but these, the only two of the five public hospitals in the colony which serve the "sugar belt," are themselves overcrowded with town patients."

The Moyne Commission's report, released in 1945, urged the British Government in that year to pass the colonial Development and Welfare Act, which established a Welfare Fund to finance expenditures for education, health services, housing, slum clearances, land settlement, and the provision of social welfare services. ${ }^{78}$ The 1945 Act was the basis of an embryonic form of development planning in Guyana, since the colony was required to formulate a ten-year development plan before it could be receive the requisite funds. The outcome was the 1947-56 ten-year development plan, which basically was a document that outlined capital expenditure over the decade. In simple terms, expenditure was targeted at three broad areas: 1. Three major drainage and irrigation projects - $\$ 6.5$ million; 2 . Social welfare, justice, and public buildings - $\$ 11.2$; and 3 . Economic services, including agriculture, forestry, transportation, surveys, and research $-\$ 10.3 .{ }^{79}$

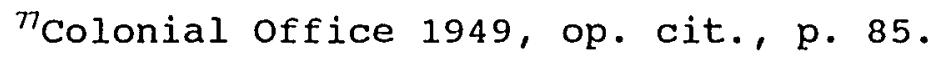

${ }^{78}$ Annual Report on British Guiana 1946, p. 6.

${ }^{79}$ British Guiana. 1947. Ten Year Development Plan 19471956. Georgetown: Legislative Council 
It was expected that roughly $\$ 20$ million of the allotted expenditure would be utilized in the first five years and that Georgetown and New Amsterdam would be the beneficiaries of a fair amount of the plan's largesse. However, because the plan was so poorly formulated, only two million dollars were disbursed by 1950 .

The advent of national development planning coincided with the colony's first serious attempt at urban planning. The increasingly active role of government in promoting change in the colony was also transferred to the area of town planning. Following the aftermath of the Great Fire of 1945, in which the civic and business center of Georgetown was destroyed, the authorities formulated a plan for South Cummingsburg, Robbstown, and Lacytown. The plan came under ordinance No. 18 of 1945 ; its purpose was to control the "height and use of premises" in the aforementioned wards of Georgetown. The government provided a grant of $\$ 200,000$ for the scheme, and five commissioners were appointed by the governor to ensure its implementation. In the following year, the Wortmanville Housing Scheme ordinance was passed (Ordinance No. 18, 1946), to ease overcrowding and the shortage of housing by providing homes for 48 working-class families. In defining working-class, the ordinance included: a) mechanics, artisans, laborers and other persons working for wages; b) hawkers; c) persons not working for wages but working at some trade or handicraft 
and employing only members of their own families; d) persons whose incomes did not exceed an average of $\$ 15$ per week, or such other sum as the committee could fix at its discretion from time to time. ${ }^{80}$

The project's modest scale made certain that many depressed and poverty-stricken inhabitants of the capital would remain unaffected by the development. Nevertheless, it established the principle that it was the government's duty to improve housing conditions and provide accommodations at reasonable prices. The Wortmanville scheme, like others before it, was restricted to short-range remedial measures that were designed and implemented on a microscale without regard to other urban problems or to long-range developments in the city. However, it was aided by two further ordinances in 1946: the Housing ordinance (Ordinance No. 24 1946) and the Town and Country Planning Ordinance (Ordinance No. 25 1946). The Housing Ordinance expanded on the Wortmanville scheme in that it attempted to provide a greater amount of housing for persons of the working class; the Town and Country Planning Ordinance provided for the "orderly and progressive development of land, cities, towns and other areas whether urban or rural," the preservation and improvement of amenities, and "other matters" connected with the planning function. The duty of carrying out the provisions of the Town and country planning

\footnotetext{
${ }^{80}$ Ordinance No. $18,1946$.
} 
ordinance, including the execution and enforcement of schemes, was vested in the Central Housing and Planning Authority (CHPA). The CHPA was granted the authority to bring under its control any land in any urban or rural area for purposes of carrying out a planning scheme. The general objective was to control the development of land by securing proper sanitary conditions and conveniences, the coordination of roads and public services, protecting and extending amenities, and conserving and developing resources of the area to which the planning scheme applies. Furthermore, the CHPA could prepare a plan, adopt with or without reservations a plan prepared by owners of land within an area, or adopt with or without reservations a scheme forwarded to it by a local authority. Indeed, local authorities were forbidden to permit any development for which they did not receive prior approval from the CHPA. One of the first tasks undertaken after the changes was a survey of living conditions in Georgetown. of the 7,994 houses surveyed, 2,309 were found to be unfit for human habitation and 5,303 in need of repair, and only 382 were declared to be structurally sound. In order to confront this dismal situation, the CHPA developed the Greater Georgetown Flan in 1950. The plan was Guyana's first attempt at comprehensive urban planning. A Greater Georgetown Planning area was created, with the objective of reconstructing and improving the city in order to render it 
capable of fulfilling the functions of a port-city which was also a regional and national capital. Particular emphasis was placed on redeveloping parts of the city center destroyed by fire in 1945, providing new housing and residential areas, creating public parks and amenities, and improving communications throughout the metropolitan area. The sudden upsurge in planning activity came at a time when the country was in the throes of rapid population growth amid increasing rural-urban migration. The concentration of population in the capital city necessitated additional housing, schools, water-supply facilities, sewage works, roads, places of employment, medical and social services, and so on. Rising standards of living also dictated that there should be improvements in Georgetown's infrastructure works.

The Greater Georgetown Plan was approved by the legislature in 1951 and was amended in 1962 following a large fire in the city center. The CHPA believed that the destruction of significant portions of Regent street, Water Street and Leopold street warranted a revision of development control in the downtown area. A draft-varying scheme modifying the Town Planning Scheme for Greater Georgetown between Robb street, Princes street, and the Demerara River was subsequently prepared. The plan recommended the renovation of the stabroek Market Square, wider pedestrian walkways along the more travelled 
commercial and retail thoroughfares, increases in front setbacks to allow the parking of cycles and loading and unloading when there was no service road, median reservations which could be used by pedestrians when crossing wide thoroughfares, separation of vehicular traffic where possible, and the creation of pedestrian malls to ease the difficulty of shopping in the downtown area.

The attention bestowed on Georgetown did not extend to New Amsterdam and the villages of Guyana. A number of planning studies and field investigations were pursued. A land-use survey of New Amsterdam and its environs was made along with a few project-planning proposals, but nothing became of these. The most significant changes in the town occurred when Reynolds, the aluminum concern from the United States, started bauxite mining at Kwakwani, 135 miles up the Berbice River. In addition, the company located a calcining plant at Everton, on the outskirts of New Amsterdam. The impact of the development, while not substantial, was enough to reinvigorate the town's growth. Migrants drawn by the bauxite operations settled in the town, and local businesses were able to prosper from the demands of these new settlers as well as from the service and commercial requirements of the industry.

Although the coastal areas were not ignored by the CHPA, they did not benefit from the development of any physical planning schemes. However, the areas outside 
Georgetown, and the capital itself, were implicitly affected by the newfound adherence to development planning. In 1953 a contingent from the International Bank of Reconstruction and Development (IBRD) was invited to Guyana to assess the country's development program. The mission found that in many spheres there had been substantial progress. Public administration, education, and public health were already developed to such a stage that they were considered to form the basis for further development of the economy. To support the expanding population, the mission suggested that a continuing high level of domestic investment was necessary. The overriding objective was to increase the country's national income as quickly as possible in order to enable it to support its population at an acceptable standard of living. An investment program of 66 million dollars over five years $(1954-58)$ was proposed. Most importantly for rural areas, it was recommended that 70 percent of the investment program be spent on projects related to agriculture (land settlements, drainage and irrigation, etc.) and transport communications, with the remainder on industrial production, electric power, forestry, housing, and public works. ${ }^{81}$ However, owing to political developments in the country, the British Government decided that conditions had deteriorated to such

${ }^{81}$ World Bank (IBRD). 1954. The Economic Development of British Guiana. Baltimore: The John Hopkins Press. 
an extent that Guyana's development would have to be accelerated and expanded to include more emphasis on infrastructure and social development. The mission had proposed an investment of 27 million dollars in two years; the government, however, decided to increase the sum to 44 million dollars and to initiate a two-year development plan for 1954-55.

The emphasis on infrastructure and social development had little to do with any sincere desire to improve the economy. Instead, increased expenditures were used to "pump-prime" the economy in an attempt to lure support away from the People's Progressive Party (PPP) following the suspension of the constitution in october 1953. In the urban areas the British Government initiated a massive lowincome housing project to neutralize African support of the PPP. The program concentrated much of its resources on the creation of sizeable housing schemes at Ruimveldt and La Penitence, on the southwestern fringe of Georgetown. Housing construction plans were also targeted for Campbellville and Lodge in Georgetown, New Amsterdam, and Anna Regina. The Public Works Department was given the green light to spend, but the lack of qualified technical personnel meant that only 26-million dollars were spent during the two years. A great deal of money was squandered on surveys and reports by foreign experts. Grandiose and expensive plans were drawn up for a seven--story hospital in 
Georgetown, a plan for a superhighway from Georgetown to Rosignol, and other lavish large-scale projects. In its haste to construct housing for the African working class, the British Government failed to adequately evaluate its plans prior to implementation. At La Penitence the cost of houses proved to be out of reach of its targeted population, and the houses ended up being occupied by the middle classes. Many houses were completed without provision for water or electricity supplies, and consequently they had to remain vacant until the snafu was remedied.

Within the countryside the British also sought to induce the Indian population away from the PPP:

The sugar workers, who until then had been living in the insanitary ranges, began to get grants to build houses, roads were improved, drainage and irrigation extended, more opportunities to rent or buy land was offered to the agricultural workers and capital development took place... ${ }^{82}$

By 1955, the PPP's African-Indian coalition had been broken. With his formation of the People's National Congress (PNC), Forbes Burnham, to the delight of the Home Government, had departed from the party and had taken with him a good deal of the urban African vote. The stage was now set whereby African and Indian tensions would increasingly be associated with those between town and

${ }^{82}$ Simms, P. 1965. Trouble in Guyana: An Account of People, Personalities and Politics as they are in British Guiana. London: George Allen and Unwin, p. 128. 
country. Expenditures on urban or rural infrastructure became dependent on the shade of the party in power. The unexpected balance arising from the 1954-1955 plan was incorporated into a new plan for 1955-1960, which was framed along the recommendations of the IBRD mission, with the inclusion of a number of new projects. The program allocated an expenditure of 91 million dollars, with emphasis on drainage and irrigation, transport and telecommunications, rural electrification, land settlement, health, housing, and education. The allocations were revised in 1957, when the PPP came into office. The expenditure target was increased to 102.5 million dollars, with most of the additional expenditure ( 8 million dollars) going towards drainage and irrigation in the rural areas. ${ }^{83}$ A new five-year plan for 1960-64, drawn up by Cambridge economist Kenneth Berrill, proposed an expenditure of 110 million dollars, 92 million dollars for economic and 18 million dollars for social development. ${ }^{84}$ with a rapid population growth of some 3 percent per year and increasing unemployment, the emphasis was on economic development through expansion of the rice industry in particular. The move towards non-plantation agriculture without agricultural diversification was made with the belief that crops other

\footnotetext{
${ }^{83}$ Sessional Paper No. 5, 1959; Legislative Council,

${ }^{84}$ Sessional Paper No. 2, 1960.
} September, 1961. 
than rice would take too long to yield adequate returns. The emphasis was on drainage and irrigation projects, land development schemes, and making land thought to be suitable for agriculture accessible. While the economic sector was heavily biased in favor of agriculture, the PPP government did propose financing to establish industries by private enterprise, or in partnership with private enterprise, and also to set up its own factories when it was deemed to be economically sound. Social-sector expenditure was centered on increasing educational and technical training facilities, expanding hospital and health services, providing a pure water supply, and improving housing. However, the urban population, comprised mainly of Africans, were unconvinced that the 3 percent of development funds allocated to industrial development and the 3.6 percent allocated to urban housing were equitable shares of the overall funds, especially when these percentages were compared to agriculture's allocation of 47 percent.

Infrastructural works undertaken in Georgetown during the 1960-64 plan period included the reconstruction of the East Bank Road between Georgetown and the international airport at Atkinson Field, construction of wells, and modernization of the Port of Georgetown.

Guyana experienced serious civil disturbances between 1962 and 1964. In 1964, a PNC-led government came into power, and immediately expenditure allocations were 
virtually reversed. The government spent the two years before independence (1964 to May 1966) constructing public buildings and pursuing public-works projects in Georgetown, New Amsterdam, Linden, and some of the other areas that were affected by the civil strife. The urban orientation of the new government would be made apparent in Guyana's first plan in the post-independence era.

\section{Land Use}

This sub-section presents a description of land use patterns over the period and discusses a number of factors which have directly influenced land use activity, including bauxite and diamond mining, Crown Lands policy, and land settlement schemes.

The establishment of the bauxite industry in 1917 dramatically altered Guyana's land-use pattern, and to a lesser extent, its spatial distribution of population. Important spatial parameters are associated with the economic activities of bauxite mining. Bauxite is extracted from where it is found, and in 1917, Demba built the town of Mackenzie, later renamed Linden, 65 miles up the Demerara River from Georgetown.

The town was reported to be a model settlement, where the houses were well laid out and the people were provided with a pure water-supply system. ${ }^{85}$ Unfortunately, the well-

\footnotetext{
${ }^{85}$ C.C. March 2, 1921 .
} 
arranged section of the town was the exclusive preserve of white expatriates who ran the mines. Indigenous laborers, overwhelmingly Africans, were accommodated in more austere surroundings, and in the adjacent villages of Christianburg and wismar. The two villages had previously been settled by persons providing services to pork-knockers and others in the gold industry. Now their growth was to be predicated upon locational decisions made overseas. Decisions were rationalized by the desire for quick profits from the sale of bauxite to external markets.

The growth of the diamond industry in the $1920 \mathrm{~s}$ brought renewed life to Bartica, but akin to the gold industry, diamond mining was to suffer through cyclical periods of booms and busts, and this instability certainly restricted the development of the town. In any case, it appeared that most of the miners or pork-knockers were intent on returning to the coast after laboring for a few months in the bush. Remittances from miners were oftentimes almost wholly responsible for the economic well-being of many African coastal villages.

Elsewhere in the interior, settlement activity remained negligible. Government policy was committed to the coast to such an extent that in 1922, Major Wood (later Viscount Halifax) formulated a proposal of separating the interior from the coastal strip and assigning it an 
independent administration. ${ }^{86}$ The distribution of land use in Guyana was set, and the pattern has continued to the present day. Sugar and rice dominated the coastal fringe, with ground provisions and coconuts on the sand reefs. on the swampy areas behind the coastal fringe, cattle were found. Large herds of cattle were once found on the coast, but these steadily retreated as the acreage under rice began to be expanded in the modern era. On the riverain lands there were root crops, fruit, coconut, and rice. In the Rupununi and intermediate savannas, cattle were reared; and in the interior forests, the timber industry had a hold in several areas.

Regarding the issue of Crown Lands, in 1938, it was decided that conditional freehold grants of crown Lands would not be made and that crown Lands would be rented under leases or licenses of occupancy for terms no longer than 99 years. A little later the terms were reduced to 21 years. Leases, licenses, and permissions to occupy Crown Lands for agriculture, cattle grazing, logging, balata extracting, quarrying, and so on were strictly enforced. In 1956, a systematic inspection of crown Lands held under title was commenced, with a view to terminating titles when the conditions attached to these titles were not being complied with. The onerous conditions attached to crown Land titles

\footnotetext{
${ }^{86}$ British Guiana. 1951. Report of the British Guiana
} Constitutional Commission. p. 9 . 
ensured meager participation rates. During 1960, for instance, only 711 applications for titles affecting 40,000 acres were granted, and these included 122 applications for renewals of expired titles. In addition, 15 renewals of permissions for grazing cattle over 872 square miles of interior savannah lands were granted, and an additional 6,000 square miles of Crown Lands were considered to be Amerindian reservations. Amerindians had been allotted Crown Lands through the Amerindian Ordinance of 1953. Under the ordinance, residents on the declared Amerindian reservations were permitted to occupy and use the land free from rates and taxes. However, within the reservations they were forbidden to hold titles for lands.

Since the end of the First World War, sporadic attempts have been made to establish land-settlement schemes and to develop existing ones. In 1923, Plantation Anna Regina was bought by the government. However, the scheme encountered many problems, and little attention was paid to land settlements until the second World War. In 1944, a plot of land comprising 170 acres and situated on the right bank of the Pomeroon River was bought by the government. Known as the Charity-Amazon Scheme, the settlement was divided into 35 agricultural and 140 house lots. The settlement was originally intended to be primarily agricultural, but in 1960 the CHPA was given the authority to develop the scheme into a township to serve the Pomeroon 
and the northern region of the Essequibo coast. Two years later, four estates - namely Vergenoegen, Philadelphia, Greenwich Park, and Barnwell - comprising a total acreage of 3,595 acres were combined to form the vergenoegen development scheme. Situated on the East Bank of the Essequibo, 18 miles from Georgetown, the settlement housed 200 families who cultivated rice and vegetables and provided milk for the Georgetown market.

In 1948, the Cane Grove-La Bonne Mere Land Development Scheme, comprising a total area of 7,233 acres in East coast Demerara, was established. Four hundred and eighty-five families were chosen, mainly from the nearby sugar estates, on account of their experience as farmers. However, the scheme's land use did not include sugar; instead, planting centered on rice and coconut cultivation, mixed farming, and pasturage.

No further settlement schemes were pursued until 1955, a time when the British Government was attempting to weaken the support of the PPP. Plantation onverwagt in West coast Berbice, comprising 6,000 acres, was allotted for rice cultivation. In the following year, two schemes were added: the Mara Land Development Scheme on the East Bank of the Berbice River, comprising 3,870 acres, was established to ease unemployment in the Indian-dominated Canje and Corentyne areas; and the ironically named Garden of Eden Land Development Scheme, comprising 1,200 acres on East Bank 
Demerara, was established just outside Georgetown. Seventyeight families were selected for the scheme, but most of these continued to live in Georgetown, preferring to be absentee farmers.

In 1960, the PPP government launched the Black Bush Polder scheme in the corentyne. Covering some 31,000 acres, the scheme was intended to house some 1,500 families. Each family was allotted a 2-1/2-acre homestead plot for the production of food crops other than rice and a 15-acre plot for rice cultivation.

In broad terms, the objectives of land-settlement schemes during the period were to take in the surplus population, reduce unemployment, foster agricultural development through the production of rice, encourage smallscale agriculture, and to a lesser extent promote agricultural diversification. All of the schemes were concentrated on the coastal strip. Many of the schemes were chosen because the land was cheap, with little thought being given to their spatial location. It was only during the early 1960s that attention was given to settlement in the interior and a few experimental schemes were initiated.

\section{Political and Social structure}

This sub-section briefly examines the political and social changes occurring in the society during the period under review. Attention is focussed on franchise requirements and the ability of ethnic groups, as well as 
urban and rural constituents, to articulate their demands through the political process.

In 1918 the total number of registered voters had increased to 4,340 - a rather anemic figure when one considers that the entire population in that year was estimated at $310,972 .{ }^{87}$ Africans comprised nearly threequarters of the electorate and Indians barely one-twentieth, whilst Europeans (mostly British), Portuguese, and Chinese were largely overrepresented. English literacy requirements had slowed the entry of Indians into the political arena, and it was not until 1916 that the first Indian, Mr. Joseph Luckhoo of New Amsterdam, was elected into the Combined Court. Despite the meager electorate, the non-white group, especially the colored and African commercial professional middle class, had been intensifying their hold on seats in the legislature. It was evident that the planters would be hard-pressed to win a seat in any future elections. To ensure planter representation, the constitution would have to be amended. A constitutional change was in the offing. The general election of 1926 returned a majority of non-whites to the legislature. Alarmed by this development and the financial condition of the colony, the British Secretary of state for the Colonies in 1926 appointed a Royal Commission to report on the economic conditions in the country and to ascertain the causes that had retarded

$$
{ }^{87} \text { B. B. , } 1918 \text {. }
$$


development. ${ }^{88}$ The commission, in its report, which was published in 1927, concluded that the major obstacle to development was the constitution, which hindered the government from effectively governing the country. The Colonial Government was said to be incapable of controlling the finances of the country, since it was dependent on the cooperation of elected members who were at best financially irresponsible. ${ }^{89}$ The commissioners recommended a change in the constitution and suggested that the details be handled by another commission. The new commission set to work in 1927 ; its report proposed the abolition of both the court of Policy and the Combined court and their replacement by a single Legislative Council. This new Crown Colony system of government was introduced in July, 1928, by an act of the British Parliament. At the final meeting of the court of Policy, Mr. Crane, the member for West Demerara, meekly closed the sitting:

The court of Policy, as far as British Guiana is concerned, has been established... since $1732 \ldots$.. it has passed through a good many shades of Government in this colony. It has seen the days of the hard toiling Dutch settler who established himself on the three rivers of the wild coast of Guiana to found the social order out of primeval chaos; it has seen the balmy days of the planter, the magnate and dandy of his day, it has seen the day when, after the reform of 1891, the proletariat obtained the lead in the Financial Chamber; and it is now decreed that under existing conditions the best thing to do for the progress of the colony is that

${ }^{88}$ British Guiana. Report on the British Guiana Commission.

${ }^{89}$ Ibid. , p. 51 . 
the Court should give way and permit another form of Government to take its place. ${ }^{90}$

Under the new constitutional arrangement, the Legislative Council consisted of the governor as president, ten official members, five government-nominated unofficial members, and 14 elected members. With a total membership of 29, unofficial members (19) were in the majority in the Legislative Council, though not an elected one. The Executive Council was constituted wholly of government officials and nominees of the governor, of whom two were elected members of the Legislative Council.

Crown Colony Government strengthened the power of the governor, since official and nominated members outnumbered those who were elected. However, the British Government was not about to take any chances. Just in case the unofficial members did not toe the government line, the governor was bestowed the power to adopt or reject any measure without majority approval if it was:

... in his opinion necessary in the interests of public order, public faith, or other first essentials of good government including the responsibilities of the colony as a component part of the British Empire...91

The revamping of the constitution extended the franchise to women, although they were still excluded from the legislature. The previous differences in qualifications

\footnotetext{
${ }^{90}$ M.C.P., JulY 17, 1928 .

${ }^{91}$ Clementi 1937, op. cit., p. 397.
} 
between town and country voters were abrogated, and uniform property qualifications for voters were decreased to include the following:

1) ownership during the six months previous to registration of not less than six acres of land; or

2) occupation or tenancy, during the six months previous to registration of not less than six acres of land secured by lease or some document in writing for three years or upwards, such lease or document to be recorded or deposited in the Deeds Registry; or

3) ownership during the six months previous to registration, of a house or land, or land with a house or other erections thereon, of the value of not less than $\$ 500$; or

4) occupation or tenancy, during the six months previous to registration, of a house or land with a house or other erections thereon, of the annual rental of not less than $\$ 100$ secured by lease or any document in writing for one year or upwards, deposited or recorded as aforesaid; or

5) possession or enjoyment of an annual income or salary which (together with any sum paid or allowed to him or on his behalf for board or lodging or board and lodging) amounts to not less than $\$ 300$ coupled with residence in the district, such possession or enjoyment and residence having subsisted during the six months previous to registration; or

6) payment during the twelve months previous to registration, of direct taxes to the colonial Revenue of $\$ 20$ or upwards, coupled with residence in the district during the six months previous to registration: provided that no licence duty of any kind shall be deemed to be within the meaning of the term "direct taxes."

A glance at the qualification requirements would suggest that residents of the rural areas were the primary beneficiaries of the new rules. Land was no longer required to be beneficially occupied. However, the acreage was increased from three to six, and this increase resulted in

${ }^{92} \mathrm{~B} . \mathrm{B} ., 1928$. 
the disenfranchisement of a number of rural dwellers. In 1930, the first year of elections in the wake of the new constitution, there were only 9,252 voters in the country's 14 electoral divisions. ${ }^{93}$ Georgetown and New Amsterdam alone accounted for 39 percent of this narrow electorate. Qualifications for the Legislative Council were of course more stringent than those for the franchise. To be eligible for membership, one needed to be in receipt of a clear income of not less than $\$ 2,400$; or in possession of immovable property of not less than $\$ 5,000$ over and above the amount of any mortgage; or in ownership, under a lease for 21 years or upwards, of any house or house and land, the annual rental of which was not less than $\$ 1,200.91$ Those who were disqualified from membership included anyone who was not entitled to vote, ministers of religion, and holders of emoluments under the crown or under the government of the colony. ${ }^{95}$ Thus, the Colonial Government had managed to continue the wide distinction between the qualifications for membership in the legislature and those for a voter. Within the Legislative Council, the governor utilized his power to nominate unofficial members by including representatives of the planting class or those who were sympathetic to this group:

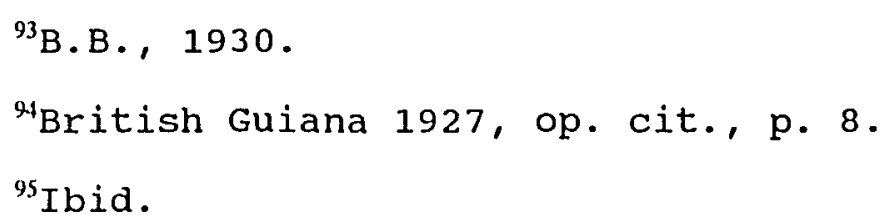


The nominated unofficial members are all men well known and respected in water street, and in connection with the staple industries of the colony. Mr. Smith, for example, is the manager of Rose Hall Estate in Berbice while Mr. Seymour, proprietor of an estate in Essequibo, of which district he is regarded as the most progressive resident, is representative of the secondary agricultural interests, including rice cultivation...96

The governor also utilized his prerogative of nominating elected members to the Executive Council by appointing men who were in agreement with the official section of the council. Of the first two appointments, neither was African or Indian, despite the fact that the two groups combined represented over 80 percent of the population and 90 percent of the voters. According to the governor, the remaining elected members were excluded from the Executive Council because:

...there is not one of whom I could say both that he is of the requisite standing in the community and that he may confidently be expected to cooperate with the government in its general policy and not to oppose it on any important question without strong and substantial reasons. ${ }^{97}$

The decade following the introduction of crown colony Government was one of widespread unrest in Guyana and elsewhere in the Caribbean. In 1935 the franchise was extended to include tenants of crown Lands, and the income and property qualifications were slightly lowered. This

${ }^{96}$ West India Circular, Sept. 6, 1928. Quoted in Lutchman 1974, op. cit., p. 197.

${ }^{97}$ Secret Despatch, Rodwell to Amery, May 7, 1928. Quoted in Lutchman 1974, op. cit., p. 199. 
change, however, failed to widen the electoral base significantly, and only 9,461 persons were registered as voters in the September general elections. ${ }^{98}$ Limited political participation and social and economic difficulties combined to foster continued working-class protest against an autocratic government and its close ally, the sugar industry. Sugar workers and the urban proletariat, particularly dockworkers, were distrustful of the British and did not believe that the colonial Government represented their interests.

Failure to quell the strife induced the British Government to appoint a commission, under the chairmanship of Lord Moyne, to investigate social and economic conditions in Guyana and throughout the British West Indian islands, and to make recommendations. The Moyne Commission, as it came to be known, visited the Caribbean in 1938, and its members undertook a year-long comprehensive study of conditions in the colonies. Its conclusion was a damning indictment of the inequities associated with colonialism. ${ }^{99}$ Such were the findings that the British Government, for security reasons, felt obliged to withhold its publication until after the second World War. The commission's recommendations, however, were allowed to be disseminated, ${ }^{99}$ Report of the West India Royal Commission $1938-39,1945$,
op. cit.

${ }^{98}$ B. B. , 1935. ${ }^{99}$ Report of the West India Royal Commission $1938-39,1945$,
op. cit. 
and these called for major economic and social reforms as well as increased liberalization of the political process. stemming from the Moyne Commission's recommendations, a number of constitutional changes were enacted in 1943. In the Legislative Council, elected members were placed in the majority; and in the Executive Council, unofficial members predominated, although the governor retained his right to pass or block legislation. Income qualifications for the franchise were reduced from $\$ 25$ to $\$ 10$ per month, and property qualifications for membership to the Legislative Council were lowered. In 1945, another extension of the franchise followed to include all literate adults. Income and property qualifications for the franchise and for the Legislative Council were reduced, and membership in the legislature was accorded to women.

New elections under the reformed constitution were held in 1947. The effect of the 1945 reduction in the franchise qualifications was most discernable. The number of voters shot up from 10,772 in 1943 to 59,384 in 1947 . over 12,000 of the new electorate were women, whilst Indian voters increased their share of the franchise to 30 percent. The elections brought a greater representation of Indians and Africans to the Legislative Council. Effectively barred from governmental jobs and upper-management positions in the dominant sugar and bauxite industries, members of the two major ethnic groups had been steadily entering the 
independent professions. This allowed them the economic independence to challenge the ruling white elite in the national political arena. Nevertheless, despite the Indians' and Africans' inroads into the new House, the Legislative Council was still dominated by white planters and their commercial allies. The governor and the colonial office helped to solidify this domination; for example, in the 1947 elections, the governor nominated F.J. Seaford, a sugar planter, to the Legislative Council, although he had been defeated at the polls.

Dr. Cheddi Jagan formed the People's Progressive Party in January 1950. The party with Jagan (an Indian) as its leader, and Forbes Burnham (an African) as its chairman, began to agitate for changes in the colony's constitution. Later in the year, the British Government appointed a Royal Commission under the chairmanship of $\operatorname{sir}$ E.J. Waddington to examine the franchise, the makeup of the legislature, and matters concerning economic and political developments, and to forward recommendations. Amongst its many findings, the commission reported:

.. We found in the villages and country districts a political climate very different from that of Georgetown, and we have been impressed also with the persistence in Essequibo, Demerara and Berbice of a sense of their distinctive identity as separate colonies, each with a long history of its own. This is largely the product of geography for even coastwise communication is rendered difficult "by the very deep and mighty rivers"... it is a feature, too, which had important political repercussions. Difficulties in communications have produced in the country at large a sense almost of 
isolation from Georgetown and the rural areas contiguous to it. A capital town naturally tends to play a predominant part in the life of any country, and it is to be expected that many men of talent and ability should gravitate towards it. Danger arises when the capital achieves a virtual political monopoly, and when an undue number of legislators are residents in the capital, possessing no roots in the constituency which returns them and professing, when elected, little active care of the interests of their constituents. In many villages we met with the complaint of neglect, and this sense of isolation may well foster the dangerous conviction that the affairs of central government do not concern them. ${ }^{100}$

The commission further pointed out that:

Sheer weight of numbers made it certain that, following emancipation, the non-European communities would eventually predominate, but owing largely to the oligarchical nature of the old constitution, the European community was for a considerable time able to retain a substantial majority in the legislature. ${ }^{101}$

In order to defuse the potential for violent political action, especially among the urban and rural proletariat, the Waddington Commission provided for universal adult suffrage at age 21 (property and income qualifications were quashed), a ministerial system of government, and a bicameral legislature consisting of a House of Assembly and a state Council. The House of Assembly, or the lower house, consisted of 24 elected members and three ex-officio members - namely, the chief secretary, the attorney general, and the financial secretary. The state Council, or the upper house,

${ }^{100}$ Great Britain. 1951. Report of Constitutional Commission, 1950-51. London: H.M.S.O., p. 15.

${ }^{101}$ Ibid., p. 16 . 
consisted of nine members - six nominated by the governor, two by the majority group in office, and one by the opposition. Government of the country was to be in the hands of an Executive Council, consisting of the following: the governor, armed with the veto power as president; the three ex-officio members of the House of Assembly; six ministers from among the elected members of the House of Assembly; and one minister without portfolio nominated, by the state council.

The first general election under the Waddingtion Constitution was held in April, 1953, and resulted in the PPP winning 18 of the 24 seats and securing well over 50 percent of the vote. ${ }^{102}$ once in office, the PPP, buoyed by its sweeping victory at the polls, began a series of progressive reforms. The Undesirable Publications ordinance, which prevented Communist publications from entering the country, was revoked; a ban to restrict the entry of radical West Indians into Guyana was lifted; the Rice Farmers' Security of Tenure ordinance of 1945 was amended to pressure landowners to provide better drainage and irrigation facilities for tenants; and moves were on the way to pass a labor-relations bill that would have made it compulsory for employers to recognize worker-supported trade unions when the British Government suspended the constitution in October 1953.

${ }^{102}$ Great Britain 1966, op. cit., p. 8 . 
To justify their actions, the colonial authorities declared that the suspension was necessary in order "to prevent Communist subversion of the government and a dangerous crisis both in public order and economic affairs."103 The plantocracy and commercial interests in Guyana had also concluded that the reforms were communistinspired, but according to Jagan:

The changes we began to introduce now seem quite modest: to bring all schools under the supervision of government and local education committees; to reform local government so that on this level, too, there would be universal adult suffrage without property limitations; to appoint working people to government boards and committees; to revise the fees of government medial officers in order to make medical care possible for the poor; to curtail unnecessary expenditure of public funds; to provide more scholarships; to bring about social security and workmen's compensation; to improve drainage and irrigation; to make available and usable, large tracts of land then uncultivated; and to review and act on the recommendations of the central Housing and Planning Authority. ${ }^{104}$

An interim government was appointed on January 1 , 1954. Many of the appointees had been defeated at the polls in 1953 and were bitter enemies of the PPP, but these and other conservative elements were considered essential in restoring the confidence of the people and in attracting investment capital from abroad. ${ }^{105}$

${ }^{103}$ British Guiana. 1953. The Constitution Suspension ordered on Oct. 8, 1953. Bureau of Public Information, p. 3 .

${ }^{104} J a g a n, \quad C .1966$. The West on Trial: My Fight for Guyana's Freedom. New York: International Publishers.

${ }^{105}$ Great Britain. 1954. Building Confidence. The story of British Guiana in 1954. Government Information Services, p. 3 . 
With the suspension of the constitution in place, a campaign designed to vilify, repress, and harass the leadership of the PPP was launched. Leaders, with the exception of Burnham, were imprisoned and placed under house arrest (Burnham was served with a restraining order, but he was allowed to violate the regulation). A concerted effort was made to break the nationalist movement and to exploit internal differences within the party. Jagan was branded a doctrinaire Communist, whilst Burnham was presented as a level-headed social democrat who was unlikely to be a threat to capital. Sensing a window of opportunity and emboldened by implicit British support, Burnham mounted a challenge for the leadership of the PPP. The move failed to dislodge Jagan, but the party was split into two competing factions. The right wing of the party went with Burnham, but Jagan was able to retain the radicals and the support of Indian and African party members. However, the broad-based national support of the PPP (Jagan) was short-lived and by 1957 a good deal of Jagan's African support had left the party. In 1956, further constitutional changes were announced, with elections slated for August 12, 1957. Additional nominated and official members were introduced into the legislative and executive councils, to reduce the power of the elected members. A concerted effort was made to ensure the demise of the Jagan faction of the PPP. Electoral districts were redrawn to place the party at 
disadvantage. On the Corentyne, a Jagan stronghold, one district contained 32,000 voters, while in Burnhamite Greater Georgetown three districts contained a total of 45,000 voters. An accelerated development program had also been launched by the interim government to demonstrate the possibilities of life without Jagan. Furthermore, the British Government reasoned that the split in the PPP, along with the restrictions imposed on the party during its four years out of office, was sufficient to ensure its defeat at the polls. It was generally felt that Jagan's PPP could win only two of the 14 seats; however, the party confounded ali observers by taking nine of the contested seats, whilst Burnham's faction won three. ${ }^{106}$

The elections of 1957 were significant, for they underscored the fundamental structural fragility of Guyanese society. All of the seats won by the Jaganite PPP were in the rural Indian districts while those won by the Burnhamite PPP were in thr urban African districts. The distinction between town and country corresponded to the occupational, class, and racial polarization of the society.

After the elections, Burnham's faction of the PPP merged with the United Democratic Party, a conservative African-based party which had won New Amsterdam, to form the People's National Congress (PNC). ${ }^{107}$ The urban African

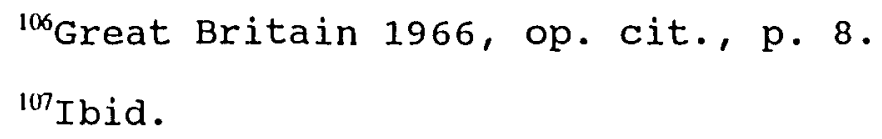


alliance ensured that race would be pivotal in Guyana's political future.

In November 1958 , a constitutional committee was set up to make recommendations on further constitutional changes in Guyana. In its recommendations, the committee suggested that Guyana become an independent state within the Commonwealth, with a cabinet and a Westminster style of government. Further talks on the constitution were held in 1960. In an effort to curtail the PPP's electoral strength, the electoral districts were revised for the forthcoming elections in August 1961; nevertheless, out of 35 seats, the PPP won 20, the PNC 11, and the United Force (U.F.), a conservative party which had been formed in 1960, the remaining four.

The PPP's return to power in 1961 signalled to the opposition that, as long as race was a determining factor in voter behavior, it would be virtually impossible to unseat the PPP from office. The faster growth of the Indian population meant that they would dominate the political arena well into the future, unless the electoral system was changed. Thus, the PNC and the UF began to lobby for the introduction of a system of proportional representation. Jagan visited the United States in October 1961, in search of aid to fund his development program, but was rebuffed by President Kennedy. Failing to obtain financing from other donors, Jagan invited Nicholas Kaldor, a 
Cambridge University economist and tax expert, to help draw up the budget and to formulate tax proposals that would generate additional revenue. The proposed budget included a capital gains tax, a compulsory savings scheme for those in the upper-income brackets, an increase in property taxes, and certain measures to prevent tax evasion. Although it was generally believed that the measures were economically sound, the UF, later supported by Burnham and the PNC, took to the streets of Georgetown. The protest quickly degenerated into rioting, arson, violence, and looting. A large swathe of the commercial center of Georgetown was destroyed on February 16, 1962. The governor declared a state of emergency, and British troops were requisitioned to quell the disturbances. In all, five people lost their lives and 80 were injured, and damage sustained to property was estimated at 11 million dollars.

The failure to topple Jagan sent Burnham to Washington in May 1962. His reception at the White House was much different from Jagan's. Arthur Schlesinger, a member of Kennedy's advisory staff, noted:

Burnham's visit left the feeling, as I reported to the president, that "an independent British Guiana under Burnham (if Burnham will commit himself to a multi-racial policy) would cause us many fewer problems than an independent British Guiana under Jagan." And the way was open to bring this about, because Jagan's parliamentary strength was larger than his popular strength: he had won 57 percent of the seats on the basis of 42.7 percent of the vote. An obvious solution would be to establish a system of 
proportional representation. ${ }^{108}$

On Burnham's return to Guyana, the central

Intelligence Agency (CIA) and British Intelligence

instigated a campaign to oust Jagan. The issue of the country's independence had been on the books for some time and was thought to be inevitable. However, the metropolitan powers were not prepared to risk having Jagan at the helm of an independent Guyana. The tabling of a labor-relations bill in 1963 provided the impetus needed to initiate the campaign of destabilization. The proposed bill, ironically modeled on the U.S. Wagner Act, would have given the government rather than employers the power to decide on the recognition of unions for worker representation. Demonstrations soon followed, and a general strike lasting 80 days ensued. The strike was marked by racial violence, which unlike previous disturbances spilled into the countryside. In the towns, the urbanization of Indians had increased the competition for jobs, which were once the exclusive domain of Africans. This was especially so in the civil service, where Indians were being increasingly employed. With the PPP in power, many Africans were fearful that they would be deprived of government jobs in favor of Indians. Since the PPP drew its support from the rural areas, it was at a great disadvantage in its confrontation

${ }^{108}$ Schlesinger, A. 1965. A Thousand Days: John F. Kennedy in the White House. Boston: Houghton Miflin, p. 778 . 
with the urban-based opposition. In a dependent economy, control of the capital city is essential if one cherishes any hope of changing economic, political, and social structures. With the party's administration centered in Georgetown, it had to run the gauntlet every time it forwarded a proposal. The strike succeeded, and the proposed bill was allowed to lapse. The strike's longevity and success must be attributed to the CIA, which used the London-based international trades-union secretariat, the Public Services International (PSI), to channel funds to support the strike. ${ }^{109}$

In the aftermath of the strike, the British Government agreed to the introduction of proportional representation. The decision infuriated the PPP and its supporters. Shortly thereafter, the majority of sugar workers went on strike in support of their claim that the Guyana Agricultural Workers Union (GAWU), a PPP-backed union, should be their official representative. The strike was opposed by the PNC and the UF, which came to the rescue of international capital. The sugar estates, in an effort to break the strike, brought in mainly African laborers. There was a tremendous racial confrontation, which resulted in the loss of 176 lives, widespread destruction of property, and the displacement of 15,000 persons who were forced to flee their residences and seek shelter in communities of their own ethnic groups.

\footnotetext{
${ }^{109}$ Sunday Times (England), April 16, 1967.
} 
Some of the worst racial violence took place in the bauxitemining town of Linden. Armed gangs were given free rein in terrorizing the 1,600 Indians out of the town and back to the coast.

Elections were held in December 1964, under the new proportional representation system. There was a 96-percent turnout of the electorate. The PPP received 45.8 percent of the votes, the PNC 40.5 percent, and the UF 12.4 percent. Accordingly, under the PR system the PPP was awarded 24 seats in the house, the PNC 22 and the UF seven. ${ }^{110}$ The PPP was the only party to have increased its share of the vote over the previous election, and under the 1961 "first-pastthe-post" system it would have had 20 out of the 35 seats, the PNC would have had 13, and the UF two. In any event, although Jagan's party had captured the most seats, the governor called upon Burnham to form the government, which he accomplished through the support of the anti-socialist UF. Thus, the PPP was finally removed from office. The Sunday Times (England) reported:

As coups go, it was not expensive: over five years the CIA paid out something over $£ 250,000$. For the colony, British Guiana, the result was about 170 dead, untold hundreds wounded, roughly E10m-worth of damage to the economy and a legacy of racial bitterness."11

On May 26, 1966, Guyana became a sovereign independent

\footnotetext{
${ }^{110}$ Great Britain 1966, op. cit., p. 15.

"IISunday Times (England), April 16, 1967.
} 
state under the premiership of Forbes Burnham. However, the ties that bound Guyana to the core remained.

\section{SUMMARY}

The externally directed termination of indentured immigration in 1917 failed to disrupt the legacy of the plantation economy. Guyana remained inexorably tied to the caprices of the core. Linkage to metropolitan markets was reinforced by the establishment of the bauxite industry, which continued the sugar industry's pattern of selective external exploitation.

The two World wars for a time fostered some degree of self-reliance and a weakening of dependency through the development of regional trade, but once the conflicts ended the country reverted to its dependent relationship with the core.

Following the Second World War, universal adult suffrage became a reality, and by the early 1950s the country was well prepared for self-rule. Urbanization increased markedly after this period. In 1960, nearly onethird of the population were residing in what were defined as urban areas, whereas in 1921 only one-fifth were so classified. The most growth took place in Georgetown, which in 1960 was ten-and-a-half times the size of New Amsterdam, the country's only other urban area.

As the sugar industry became mechanized, the promise 
of jobs in bauxite and on the American bases in Georgetown stimulated an exodus of people leaving the countryside to look for work in the towns. These events occurred at a time when significant demographic changes were taking place in the society. Falling death rates and rising birth rates, coexisting with surplus labor in the countryside, led to rural-urban migration. Migration to Georgetown, and to a lesser extent New Amsterdam, became the geographical expression on the part of the rural population to avoid unemployment in the countryside. There was a marked effect on population settlement and mobility. The development pattern was one of accretion to the existing urban areas rather than the creation of new settlements. In-migration during this period was consequently a chief contributor to urban growth in general and to suburban expansion in particular.

once indentured immigration had ended, the colonial authorities and sugar planters were particularly attentive to conditions on the estates. Health care, housing, sanitation, and flood control were all improved. However, it was the eradication of malaria which was perhaps the single most important factor that was responsible for the upswing of population growth in the countryside. The government responded to the population increases by undertaking land-settlement schemes to ease rural population pressures and to prevent migration to the towns. The 
schemes were insufficient and piecemeal. They did little to deter migration, and as a result the spatial isolation of the two major ethnic groups continued, although they began to slowly dissolve in the urban milieu.

Closer contact between Indians and Africans brought with it increased friction. For a short while the nationalist PPP had managed to galvanize the African urban proletariat and the Indian rural proletariat into a united force against colonialism and the established power structure, but class affinities failed to bridge the ethnic differences and geographical separation in the plural society. The late 1950 s and early 1960 s were an exceptionally troubling period in Guyana's history, and the importance of external factors in fomenting internal conflict cannot be denied. The metropolitan powers were exceedingly alarmed that Guyana's economic and political ties to the West might be jettisoned through the establishment of a pro-Soviet state. The externally controlled bauxite and sugar industries were fearful of nationalization, and as a result, by means of a destabilization policy, the United states and Great Britain endeavored to change the course of the country's history on behalf of international capital.

Through urban and national development planning, the state began to play an ever-increasing role in the organization of the space economy. Urban planning was 
confined to Georgetown and to short-range remedial measures that were designed on a microscale without regard to other urban problems or to long-range developments in the city. The British attempted to stymie urban African support of the PPP by providing housing projects in the capital. The transfer of government in 1957 lessened the urban emphasis, for although the PPP stressed the need for planned development in keeping with its socialist philosophy, its orientation was decidedly rural. The rural bias of the party cannot be ascribed solely to the PPP's proclivity to reward its Indian population; rather, there was a general belief that the country's comparative advantage was in agriculture. Furthermore, the PPP reasoned that a viable peasant sector would provide a sound alternative to the tyranny of the plantation sector. Industrial and urban infrastructural development would have to be sacrificed, since their optimal development would be dependent on the viability of the agricultural sector.

The ouster of the PPP from power in 1964 signalled a reversal in planning policy. State action in the two years prior to independence had a decidedly urban flavor. The PNC, s urban bias was a harbinger of events to come - the politics of race ensured that this would be the case. 
CHAPTER V

POST-INDEPENDENCE 1966-PRESENT

GLOBAL LINKAGES

This section outlines a number of economic policies which have been attempted in the post-independence era, and surveys their resultant effects on the country's linkage to the core. In particular, the section assesses the 1966 "industrialization by invitation" program, the 1970 Cooperative Republic policy of national self-reliance, and the attempts at demand management in the late 1980 s and early 1990s, at the behest of the International Monetary Fund (IMF).

In 1966, the government moved to diversify the economy by adopting a policy of "industrialization.by invitation." The "industrialization by invitation" program was designed, much like Puerto Rico's Operation Bootstrap, to solve Guyana's economic problems of unemployment, underdevelopment, and slow economic growth, through large inputs of foreign capital investments. The policy was abandoned in the latter part of 1969 , when the reality was 
all too apparent that it had failed to open up the economy. In 1966, exports of sugar, rice, and bauxite accounted for 84 percent of total export earnings. By 1970, the three commodities together comprised over 88 percent of the country's export earnings (Table XX).

TABLE XX

EXPORT EARNINGS OF SUGAR, RICE, BAUXITE 1966-1989 (PERCENTAGES)

\begin{tabular}{|c|c|c|c|c|}
\hline Year & sugar & $\underline{\text { Rice }}$ & Bauxite & Total \\
\hline 1966 & 29.3 & 13.3 & 41.6 & 84.2 \\
\hline 1967 & 32.9 & 12.8 & 39.0 & 84.7 \\
\hline 1968 & 31.3 & 12.0 & 42.1 & 85.4 \\
\hline 1969 & 37.0 & 8.1 & 42.0 & 87.1 \\
\hline 1970 & 29.6 & 6.8 & 51.7 & 88.1 \\
\hline 1971 & 34.5 & 7.2 & 45.7 & 87.4 \\
\hline 1972 & 36.3 & 8.3 & 42.8 & 87.4 \\
\hline 1973 & 29.5 & 8.3 & 46.0 & 83.8 \\
\hline 1974 & 51.3 & 8.1 & 33.4 & 92.8 \\
\hline 1975 & 51.3 & 10.0 & 31.0 & 92.3 \\
\hline 1976 & 38.9 & 11.3 & 44.7 & 94.9 \\
\hline 1977 & 28.9 & 10.1 & 43.6 & 82.6 \\
\hline 1978 & 32.4 & 12.8 & 44.2 & 89.4 \\
\hline 1979 & 32.8 & 10.9 & 44.0 & 87.7 \\
\hline 1980 & 24.7 & 8.9 & 48.3 & 81.9 \\
\hline 1981 & 37.4 & 11.3 & 44.1 & 92.8 \\
\hline 1982 & 37.0 & 7.3 & 36.4 & 80.7 \\
\hline 1983 & 37.6 & 11.5 & 37.8 & 86.9 \\
\hline 1984 & 32.4 & 10.4 & 43.9 & 86.7 \\
\hline 1985 & 29.1 & 6.5 & 47.7 & 83.3 \\
\hline 1986 & 38.9 & 6.2 & 33.1 & 78.2 \\
\hline 1987 & 43.3 & 6.5 & 34.9 & 84.7 \\
\hline 1988 & 37.0 & 6.5 & 36.8 & 80.3 \\
\hline 1989 & 32.7 & 5.7 & 31.3 & 69.7 \\
\hline
\end{tabular}

Source: Statistical Bureau; Bank of Guyana Annual Reports.

1. Includes molasses and rum.

2. Includes alumina, dried and calcined bauxite.

The sharp increase in the value of export earnings 
during 1966-1970 was obtained primarily through bauxite, which experienced a surge in export prices. Bauxite export earnings increased from $78 \mathrm{million}$ dollars in 1966 to 139 million dollars in 1970. On the other hand, sugar earnings increased more modestly from 55 million dollars in 1966 to 79 million dollars in 1970, whilst the export earnings of rice declined from 25 million dollars to 18 million (Table $\mathrm{XXI)}$.

The dependence on sugar, rice, and bauxite for export earnings was reinforced by the fact that there was a concentration of trading partners (Table XXII). Guyana's export market was heavily aependent on the United Kingdom, Canada, the United States, and the Caricom (Caribbean Common Market) countries. Market concentration was highlighted by the facts that the United Kingdom was the chief recipient of Guyana's sugar, the united states and canada were the chief recipients of Guyana's bauxite, and the Caricom was the chief recipient of Guyana's rice. Between 1964 and 1970, Guyana's four major trading partners dominated its export market. However, the relative export shares amongst the group underwent some interesting changes during this period. The United States became Guyana's largest export market (28 percent) by displacing Canada (19 percent) and the United Kingdom (20 percent). Much of the increase in exports to the United States came at the expense of the Canadian market, which was quickly becoming a less important 
TABLE XXI EXPORT EARNINGS OF SUGAR, RICE, BAUXITE 1966-1989
(G\$ MILLIONS)

\begin{tabular}{|c|c|c|c|c|}
\hline Year & Tot. Exports & sugarl & $\underline{\text { Rice }}$ & Bauxite \\
\hline 1966 & 186.4 & 54.7 & 24.9 & 77.6 \\
\hline 1967 & 197.5 & 64.9 & 25.2 & 77.1 \\
\hline 1968 & 216.3 & 67.7 & 26.1 & 91.2 \\
\hline 1969 & 242.0 & 89.6 & 19.7 & 101.6 \\
\hline 1970 & 268.0 & 79.4 & 18.3 & 138.6 \\
\hline 1971 & 298.4 & 102.8 & 21.3 & 136.4 \\
\hline 1972 & 305.0 & 110.7 & 25.3 & 130.4 \\
\hline 1973 & 293.0 & 86.6 & 25.0 & 134.9 \\
\hline 1974 & 602.5 & 309.2 & 49.0 & 201.0 \\
\hline 1975 & 848.2 & 435.4 & 84.8 & 262.9 \\
\hline 1976 & 648.9 & 252.4 & 73.6 & 290.1 \\
\hline 1977 & 661.8 & 191.5 & 66.8 & 331.0 \\
\hline 1978 & 750.2 & 243.5 & 96.0 & 332.0 \\
\hline 1979 & 742.7 & 243.7 & 80.8 & 326.8 \\
\hline 1980 & 992.6 & 244.8 & 87.6 & 479.3 \\
\hline 1981 & 974.3 & 364.9 & 110.0 & 429.5 \\
\hline 1982 & 775.5 & 287.3 & 56.7 & 282.4 \\
\hline 1983 & 566.0 & 212.8 & 64.9 & 214.1 \\
\hline 1984 & 790.0 & 255.8 & 82.1 & 347.0 \\
\hline 1985 & 869.3 & 253.0 & 56.6 & 414.4 \\
\hline 1986 & 920.8 & 358.5 & 57.0 & 304.6 \\
\hline 1987 & $2,406.0$ & $1,042.2$ & 157.1 & 840.2 \\
\hline 1988 & $2,123.1$ & 785.8 & 138.5 & 782.2 \\
\hline 1989 & $6,452.0$ & $2,109.6$ & 367.4 & $2,022,0$ \\
\hline
\end{tabular}

Source: Statistical Bureau; Bank of Guyana Annual Reports.

1. Includes molasses and rum.

2. Includes alumina, dried and calcined bauxite.

destination for Guyana's bauxite.

Guyanese imports between 1964 and 1970 mirror its export market concentration with dependence on the United Kingdom, Canada, the United States, and Caricom (Table XXII). However, imports from among the four major trading partners were more stable throughout the period. The United Kingdom was the largest import market, followed by the 
United States, the Caricom countries, and Canada.

TABLE XXII

EXPORTS AND IMPORTS WITH SELECTED MAJOR TRADING PARTNERS 1964-1976

(PERCENTAGES)

Exports

$\underline{1964} \underline{1969} \underline{1970} \underline{1971} \underline{1972} \underline{1973} \underline{1974} \underline{1975} 1976$

$\begin{array}{lllllllllll}\text { UK } & 20.0 & 24.2 & 19.7 & 24.6 & 29.0 & 29.3 & 20.8 & 28.5 & 26.7\end{array}$

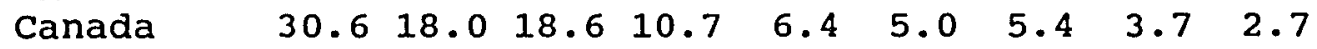

$\begin{array}{llllllllll}\text { USA } & 15.7 & 25.1 & 27.6 & 26.0 & 25.2 & 21.4 & 27.6 & 23.7 & 19.6\end{array}$

$\begin{array}{llllllllll}\text { Caricom } & 13.9 & 11.8 & 13.2 & 16.2 & 13.4 & 16.0 & 11.5 & 12.5 & 16.1\end{array}$

Rest of

the world $19.8 \quad 20.9 \quad 20.9 \quad 22.5 \quad 26.0 \quad 28.3 \quad 34.7 \quad 31.6 \quad 34.9$

Imports

$\begin{array}{llllllllll}\text { UK } & 33.3 & 31.4 & 31.0 & 30.9 & 30.3 & 25.4 & 20.5 & 21.4 & 23.0\end{array}$

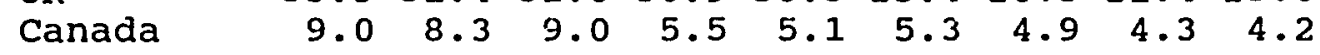

$\begin{array}{llllllllll}\text { USA } & 22.6 & 21.4 & 23.5 & 24.3 & 24.3 & 24.2 & 25.7 & 29.3 & 28.5\end{array}$

$\begin{array}{llllllllll}\text { Caricom } & 11.6 & 13.7 & 14.1 & 15.1 & 17.2 & 22.2 & 26.5 & 22.5 & 22.5\end{array}$

Rest of

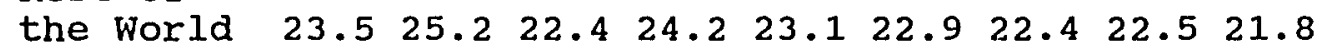

Source: Government of Guyana 1974; Statistical Bureau.

In 1970, the government signalled a change in policy by declaring the country a Cooperative Republic. Within the framework of its newly professed socialist objectives, the government announced a policy of national self-reliance, whereby:

...Guyana must itself produce the basic requirements of its people, must itself decide on its trade and other external policies. ${ }^{1}$

In pursuit of its self-reliant strategy, the

${ }^{1}$ King, K.F.S. 1973. A Great Future Together. Georgetown: Ministry of Information, p. 3. Quoted in Jeffrey and Baber 1986, op. cit. 
government embarked on a program which was aimed at controlling the commanding heights of the economy. A program of nationalizing foreign-owned industries ensued. Between 1970 and 1976, an aggressive acquisition program resulted in the nationalization of sugar and bauxite, Guyana's two largest industries. In 1971, Demba, a subsidiary of Alcan, was nationalized; and this action was followed in 1975 by the nationalization of American-owned Reynolds, the other bauxite TNC operating in Guyana. The two British TNCs which controlled the sugar industry, Jessels Securities and Bookers, were nationalized in 1975 and 1976, respectively. By 1980 the government boasted proudly that it was in control of 80 percent of the economy. The transfer of the economy into the hands of the state did little to alter Guyana's linkages to the core. The commitments to sugar and bauxite exports were retained, despite calls to diversify the economy and the establishment of closer iinks with China, the Soviet Union, and countries of the Eastern Bloc. Data on trading partners after 1976 is not readily available; nevertheless, in this year (six years after the proclamation of the Cooperative Republic), the United Kingdom, Canada, and the United States absorbed 49 percent of Guyana's exports and were responsible for 56 percent of the country's imports (Table XXII). Trade with the Sino-Soviet Bloc increased in the post-1970 period, but in 1973 this geopolitical grouping accounted for only 3.4 
percent of the country's total trade. ${ }^{2}$

In the early 1970s, Guyana's three major export earners - sugar, bauxite, and rice - were aided by exceptionally high world commodity prices, which were prevailing at the time. Between 1970 and 1975, the export price of sugar witnessed a fivefold increase, while the price of rice more than tripled. Although increases in the export prices for dried bauxite and alumina were not as significant, those for calcined bauxite tripled (Table XXIII) .

TABLE XXIII

UNIT VALUES OF MAJOR EXPORTS 1970-1981

(G\$ PER LONG TON)

$\begin{array}{rrrrcr}\text { Year } & \text { Sugar } & \text { Rice } & \begin{array}{c}\text { Dried } \\ \text { Bauxite }\end{array} & \begin{array}{c}\text { Calcined } \\ \text { Bauxite }\end{array} & \text { Alumina } \\ 1970 & 261.2 & 309.9 & 19.0 & 68.8 & 143.2 \\ 1971 & 273.6 & 313.8 & 19.5 & 81.1 & 134.2 \\ 1972 & 339.3 & 360.7 & 19.3 & 100.1 & 112.2 \\ 1973 & 337.0 & 520.8 & 19.4 & 114.6 & 125.6 \\ 1974 & 941.7 & 960.7 & 20.6 & 164.0 & 157.3 \\ 1975 & 1,449.4 & 1,034.1 & 30.4 & 211.3 & 211.6 \\ 1976 & 871.0 & 1,036.6 & 40.8 & 260.7 & 243.0 \\ 1977 & 894.0 & 1,013.6 & 46.7 & 305.2 & 298.5 \\ 1978 & 835.4 & 916.0 & 48.5 & 349.1 & 327.4 \\ 1979 & 875.0 & 965.3 & 54.2 & 402.5 & 370.3 \\ 1980 & 1,239.8 & 1,100.6 & 62.7 & 515.1 & 492.5 \\ 1981 & 1,130.4 & 1,410.3 & 78.5 & 527.3 & 614.3\end{array}$

Source: Thomas 1982, p. 24 .

The export-led boom immediately fuelled a demand for imports. In 1971 the government, in an effort to reduce

${ }^{2}$ Government of Guyana. 1974. A Decade of Progress. Georgetown, pp. 50-51. 
dependency and stimulate domestic production, banned a wide array of consumer goods including 100 items of food. The foreign exchange windfall, nevertheless, encouraged the expansion of central government expenditures. Unfortunately, the expansion in expenditures came at a time when the record-high world sugar prices of 1975 had begun to wane. The government, however, believed that the fall in world prices was an aberration; it therefore continued to press ahead with its nationalization program, the establishment of new state ventures, and the expansion of existing ones. Within a short time the lack of caution exercised by the government, combined with the high price of imported oil and manufactured goods, resulted in a balanceof-payments crisis that has continued to the present time (Table XXIV).

In the wake of its worsening balance-of-payments situation, the government sought external financial assistance from the International Monetary Fund (IMF) in July 1978. A one-year standby loan for 6.25 million SDRs (Special Drawing Rights, the currency unit of the IMF - in 1983, 1 SDR was equivalent to US \$1.10) was agreed upon. In return, Guyana agreed to pursue a policy of demand management, whereby the government would reduce spending in order to decrease the demand for imports. To implement the policy, the government eliminated subsidies on many basic commodities including milk, rice, flour, and cooking oil; it 
TABLE XXIV

BALANCE OF VISIBLE TRADE 1970-1989 (G\$ MILLIONS)

$\begin{array}{lrrr}\text { Year } & \text { Exports } & \text { Imports } & \text { Balance } \\ 1970 & 268.0 & 268.2 & -0.2 \\ 1971 & 298.4 & 267.6 & +30.8 \\ 1972 & 305.0 & 297.9 & +7.1 \\ 1973 & 293.0 & 372.5 & -79.5 \\ 1974 & 602.5 & 567.0 & +35.5 \\ 1975 & 848.2 & 810.6 & +37.6 \\ 1976 & 648.9 & 927.4 & -278.5 \\ 1977 & 661.8 & 804.3 & -142.5 \\ 1978 & 750.2 & 711.1 & +39.1 \\ 1979 & 742.7 & 810.1 & -67.4 \\ 1980 & 992.6 & 1,010.0 & -17.4 \\ 1981 & 974.3 & 1,236.5 & -262.2 \\ 1982 & 775.5 & 840.4 & -64.9 \\ 1983 & 566.0 & 738.3 & -172.3 \\ 1984 & 790.0 & 811.3 & -21.3 \\ 1985 & 869.3 & 959.8 & -90.5 \\ 1986 & 920.8 & 1,030.0 & -109.2 \\ 1987 & 2,406.0 & 2,619.0 & -213.0 \\ 1988 & 2,123.1 & 2,125.3 & -2.2 \\ 1989 & 6,452.0 & 7,012.0 & -560.0\end{array}$

Source: Statistical Bureau; Bank of Guyana Reports.

introduced new revenue measures by increasing airport exit taxes, transportation fares, and telephone and other public utility charges; and it moved to curb government spending through the imposition of a policy of wage restraint and retrenchment. ${ }^{3}$ In August 1979, a three-year Extended Fund Facility for 62.75 million SDRs was reached, which included more of the IMF's typical array of restrictive measures aimed at reducing demand and limiting the growth of the

\footnotetext{
${ }^{3}$ Caribbean Contact, October 1978 .
} 
public sector. However, by the end of 1979 , it was clear that the IMF remedy was not working. A new IMF Extended Fund Facility for 100 million SDRs was negotiated along with a structural adjustment loan of 22 million U.S. dollars from the World Bank, the object of which was to stimulate the supply side of Guyana's economy. While the IMF loan carried its now-familiar policies, the World Bank's loan was to be used to establish an export development fund and to buy machinery and spare parts for the electricity, forestry, fishing, and bauxite industries, ${ }^{4}$ in an effort to increase export production.

Guyana failed to meet the targets set by tine IMF-World Bank Group and was compelled to withdraw from the agreement in 1982. More overtures were made to the IMF in 1983, but these offers subsequently fell through. In 1984, the Guyana dollar was devalued by over 33 percent to satisfy IMF conditions. The agency had become Guyana's largest creditor, and in 198531.7 million dollars, or nearly 41 percent of Guyana's export earnings for that year, were destined for the IMF to service the country's debt. The payments were much too onerous; Guyana subsequently defaulted and was declared not credit-worthy for additional financing by the IMF. At the end of 1988, the total debt had reached 1,764 million U.S. dollars, or seven times the

\footnotetext{
${ }^{4}$ Thomas, C. 1982. "Guyana: the IMF-World Bank Group and
} the General Crisis." Social and Economic Studies 31 (4), p.52. 
level of exports. Debt service payments accounted for 75 percent of exports, and interest service payments 30 percent of exports. With a foreign debt approaching 2,500 U.S. dollars for every man, woman, and child, Guyana had become one of the most heavily indebted countries in the world in terms of per-capita debt and debt ratios to GDP and exports. In March 1989, another structural adjustment program was agreed upon between the Guyana Government and the IMFWorld Bank Group. An Economic Recovery program (ERP) was established, to be implemented in three stages:

1. Stabilization (March 1989-November 1989), 2. Rehabilitation (1990-1991), and 3. Recovery and growth (1992-). During the first two years, the objectives of the ERP were quite ambitious; they included an increase of the GDP growth rate to 4 percent per annum, a reduction in the inflation rate from 50 to 10 percent, a reduction in the public sector deficit to 20 percent of the GDP, the elimination of payments arrears, and the restoration of net international reserves.

Implementation of the ERP began in earnest with the 1989 budget when the Finance Minister announced a 70 percent devaluation from 10 dollars to 33 dollars to 1 U.S. dollar, with the full transfer of the increases on retail prices. A number of measures were also taken to reduce price distortions, in order to increase export production and to reduce the fiscal and balance-of-payments deficits. 
Two years into the ERP program, the government once again failed to meet most of the targets set by the IMF. In February 1991, the Finance Minister, Carl Greenidge, acknowledged that the IMF had given the government a reprieve despite its default on the targets. ${ }^{5}$ His budget of 1991 was not very different from those of the past several years. Once again the largest slice of the budget, some 43 percent, was allocated towards debt servicing. The Guyana dollar was devalued from 45 dollars to 101.75 dollars for 1 U.S. dollar, and a number of financial and fiscal measures were introduced, aimed at creating a more efficient market economy.

Whilst it is true that many of Guyana's balance-ofpayments difficulties have been externally generated by unfavorable patterns of the terms of trade, and by questionable policy dictates of the multilateral financing institutions, it should be pointed out that the crisis was also one of production. This aspect of the present crisis will be more fully discussed in the following section (Industrial structure), but a brief look at the export of sugar, rice and bauxite/alumina between 1980 and 1989 reveals the extent of the failure. Even though the country was guaranteed markets for sugar and ready outlets for rice and bauxite, its three major exports have all witnessed significant declines. Between 1980 and 1989, sugar exports

${ }^{5}$ Stabroek News, February 21, 1991. 
fell from 248,000 tons to 166,000 tons, rice fell from 80,000 tons to 39,000 tons, dried bauxite from 994,000 tons to 950,000 tons, calcined bauxite from 594,000 tons to 341,000 tons, and alumina exports (which were 226,000 tons in 1980) actually ceased production in 1983 (Table XXV).

TABLE XXV

EXPORT OF SUGAR, RICE, BAUXITE, 1980-1989

(THOUSANDS OF LONG TONS)

\begin{tabular}{|c|c|c|c|c|c|c|}
\hline Year & Sugar & Rice & $\begin{array}{l}\text { Dried } \\
\text { Bauxite }\end{array}$ & $\begin{array}{l}\text { Calcined } \\
\text { Bauxite }\end{array}$ & Alumina & $\frac{\text { Total }}{\text { Bauxite }}$ \\
\hline 1980 & 248 & 80 & 994 & 594 & 226 & 1,814 \\
\hline 1981 & 263 & 77 & 995 & 488 & 150 & 1,633 \\
\hline 1982 & 252 & 34 & 692 & 367 & 93 & 1,152 \\
\hline 1983 & 219 & 39 & 786 & 342 & - & 1,128 \\
\hline 1984 & 211 & 72 & 1,097 & 535 & - & 1,632 \\
\hline 1985 & 215 & 29 & 1,051 & 535 & - & 1,586 \\
\hline 1986 & 212 & 37 & 931 & 448 & - & 1,379 \\
\hline 1987 & 184 & 68 & 898 & 453 & - & 1,351 \\
\hline 1988 & 135 & 55 & 866 & 410 & - & 1,276 \\
\hline 1989 & 166 & 39 & 950 & 341 & na & 1,291 \\
\hline
\end{tabular}

Source: Statistical Bureau. na - not available.

\section{INDUSTRIAL STRUCTURE}

This section looks at the sectoral origins of the GDP since 1966. It highlights the remarkable consistency of the industrial structure, save for the decline of the mining sector in the latter half of the 1980s.

Export specialization and concentration in primary products have continued to dominate Guyana's industrial structure in the post-independence period. The preservation 
of colonial patterns of global economic linkages was mirrored by the lack of transformation in the domestic structure of the economy. In terms of the sectoral origins of the GDP, the period since 1966 highlights the remarkable consistence of the industrial structure, save for the decline of the mining sector in the latter half of the $1980 \mathrm{~s}$ (Table XXVI).

TABLE XXVI

SELECTED SECTORAL CONTRIBUTION TO GDP 1966-1989 (PERCENTAGES)

$\begin{array}{lcccccc}\text { Sector } & 1966 & \underline{1970} & \underline{1975} & \underline{1980} & \underline{1985} & \underline{1989} \\ \text { Agriculture } & 26.5 & 23.4 & 40.0 & 27.8 & 31.0 & 43.5 \\ \quad \text { Sugar } & (12.5) & (12.4) & (30.6) & (14.8) & (13.2) & (26.0) \\ \quad \text { Rice } & (5.7) & (3.7) & (3.8) & (3.8) & (3.4) & (4.0) \\ \text { Mining } & 17.2 & 20.4 & 13.0 & 16.5 & 3.1 & 2.1 \\ \quad \text { Bauxite } & & (19.5) & 12.1 & (1.3) & (0.5) & \\ \text { Manufacturing } & 7.7 & 8.2 & 6.3 & 8.1 & 9.8 & 8.9 \\ \text { Services } & 48.6 & 48.0 & 40.7 & 47.6 & 56.1 & 45.5 \\ \quad \text { Government } & (12.4) & (13.2) & (14.6) & (18.7) & (21.2) & (14.9)\end{array}$

Source: Statistical Bureau.

Agriculture, which was the second-largest sector in 1966, accounted for 26.5 percent of the GDP and continued to be the mainstay of the economy; and in recent years its role has grown, while that of the mining sector has declined. After agriculture suffered a slight decline in 1970, value added by this sector soared to 40 percent of GDP in 1975 when world prices for sugar, the dominant component of the sector, reached record levels. There followed another decline, and by 1980 agriculture's share of the GDP was 27.8 
percent. In 1985, agriculture represented 31 percent of the overall GDP, and by 1989 its dominance of domestic production was evidenced by its 43.5 percent share; at the same time, sugar's contribution to the GDP rose from 13.2 percent to 26 percent. Throughout the 1966-1989 period, rice, the other major component in the agriculture sector, basically held steady at around 4 percent of the GDP. The mining sector, by contrast, declined from a level of 17.2 percent of GDP in 1966 to 2.1 percent in 1989 . In 1970 mining was 20.4 percent of GDP and was challenging agriculture (23.4 percent of GDP) for the second-largest sector of the economy. However, following the nationalization of the bauxite industry (1971-1975), the chief contributor to the mining sector, its proportion of GDP declined to 13 percent in 1975, and to 2.1 percent in 1989.

Bauxite's decline was spectacular. In 1970, bauxite represented over 95 percent of mining's sectoral output; but in 1989, when mining's contribution to GDP was already quite poor, its share of the mining sector was less than 25

percent. Gold and diamonds, by default, have become mining's dominant industries as measured by direct concribution to the GDP. This reversal has occurred even though recorded levels of gold and diamond production have also declined (Table XXVII). 
TABLE XXVII

PRODUCTION OF GOLD AND DIAMONDS 1981-1989

Year

1981

1982

1983

1984

1985

1986

1987

1988

1989
Gold (Grams)

599

268

143

328

323

436

666

585

538
Diamonds

(Metric Carat)

$$
\begin{array}{r}
10 \\
11 \\
12 \\
8 \\
12 \\
9 \\
7 \\
4
\end{array}
$$

Source: Statistical Bureau.

The manufacturing sector has been remarkably steady in the post-independence era. Its contribution to GDP has increased only marginally, from 7.7 percent in 1966 to 8.9 percent in 1989. The manufacturing base, much like those in

- the rest of the economy, is extremely narrow. Most of the manufacturing sector is dependent on light industries such as food, pharmaceuticals, clothing, and furniture. This sector has shown no sign of dynamic growth or takeoff, despite the government's efforts in the early postindependence period to provide such stimuli as tax holidays, accelerated depreciation of investment, and duty-free imports of raw materials, building materials, and machinery. In later years, attempts were also made to promote manufacturing through import restrictions via tariffs, quotas, and outright banning of items.

The main constraints to the development of the 
manufacturing sector have been the small size of the home market; low per-capita levels of income; shortages and unreliable supplies of inputs; the government's previous emphasis on cooperatives and its insistence on equal participation in some enterprises; the limited availability of investment finance; shortages of administrative, skilled and semi-skilled persons, particularly managerial staff; and the concentration of manufacturing activities in the capital city, which provides rather weak linkages with other economic sectors and geographical areas. Apart from these factors, the lack of dynamism in the manufacturing sector can also be explained in part by the uncertain political climate and racial problems which continue to plague the country.

Throughout the post-independence era, services have been the dominant sector of the economy. Although the sector's relative share of the GDP fell from 48.6 percent in 1966 to 45.5 percent in 1989 , it did contribute 56.1 percent to the GDP in 1985. The service sector is a catch-all category that includes distribution, transportation and communication, rent, financial services, government, and so on. Within the service sector, the government component has been very strong. In 1985, government represented 21.2 percent of the total GDP and 62 percent of the service sector's GDP. Since 1985 it has declined, and in 1989 it was only 15 percent of the total GDP. This figure, however, 
masks the true importance of the government sector in Guyana's economy, for it excludes the government's involvement in agriculture (primarily sugar), mining, and manufacturing. In fact, the government is involved in just about every facet of the economy.

The poor performance of the economy since independence is, amongst other things, conditioned by the agricultural and mining sectors, and, in particular, by their major components - sugar, rice, and bauxite.

Sugar production in 1970 was 311,000 tons; the following year the industry achieved a peak output of 369,000 tons. Ou'put has since declinea precipitously, and in 1989 production was a mere 164,000 tons (Table XXVIII). Between 1970 and 1980, sugar production fluctuated, and it averaged around 306,000 tons per annum for the period. Production has since fallen considerably; and between 1981 to 1989 , average annual output was only 235,000 tons. What accounts for sugar's declining production? Among reasons cited are industrial unrest, which has led to numerous and in some cases quite protracted strikes; lack of foreign exchange and balance-of-payments difficulties, which have hindered the industry from purchasing spare parts and other necessary inputs; cane diseases; and the vagaries of the weather. ${ }^{6}$

The poor production figures have meant that Guyana has

${ }^{6}$ Shahabuddeen 1983, op. cit., p.46. 
been unable to meet its Lome Convention quotas, which

TABLE XXVIII

PRODUCTION OF SUGAR, RICE, BAUXITE 1970-1989

(THOUSANDS OF LONG TONS)

\begin{tabular}{|c|c|c|c|c|c|c|}
\hline Year & Sugar & $\underline{\text { Rice }}$ & $\begin{array}{l}\text { Dried } \\
\text { Bauxite }\end{array}$ & $\begin{array}{l}\text { Calcined } \\
\text { Bauxite }\end{array}$ & Alumina & $\begin{array}{l}\text { Total } \\
\text { Bauxite }\end{array}$ \\
\hline 1970 & 311 & 143 & 2,289 & 717 & 312 & 3,318 \\
\hline 1971 & 369 & 120 & 2,101 & 710 & 305 & 3,116 \\
\hline 1972 & 315 & 94 & 1,652 & 690 & 257 & 2,599 \\
\hline 1973 & 266 & 110 & 1,665 & 637 & 234 & 2,536 \\
\hline 1974 & 341 & 153 & 1,383 & 726 & 311 & 2,420 \\
\hline 1975 & 300 & 160 & 1,350 & 778 & 294 & 2,422 \\
\hline 1976 & 333 & 110 & 969 & 729 & 265 & 1,963 \\
\hline 1977 & 242 & 210 & 1,001 & 709 & 273 & 1,983 \\
\hline 1978 & 325 & 182 & 1,024 & 590 & 236 & 1,850 \\
\hline 1979 & 298 & 143 & 1,117 & 589 & 160 & 1,866 \\
\hline 1980 & 270 & 166 & 1,103 & 598 & 212 & 1,915 \\
\hline 1981 & 301 & 163 & 982 & 505 & 167 & 1,654 \\
\hline 1982 & 287 & 179 & 958 & 386 & 93 & 1,437 \\
\hline 1983 & 252 & 147 & 761 & 310 & - & 1,071 \\
\hline 1984 & 242 & 184 & 823 & 520 & - & 1,343 \\
\hline 1985 & 241 & 155 & 1,096 & 464 & - & 1,560 \\
\hline 1986 & 245 & 169 & 1,036 & 434 & - & 1,470 \\
\hline 1987 & 221 & 145 & 921 & 419 & - & 1,340 \\
\hline 1988 & 167 & 128 & 953 & 394 & - & 1,347 \\
\hline 1989 & 164 & 140 & 1,040 & 294 & na & 1,334 \\
\hline
\end{tabular}

Source: Statistical Bureau. na - not available.

guarantee the country a special price and the EEC market. The failure of the industry has also resulted in the further closure of sugar estates. In 1986, the closure of the sugar estate at Leonora was another signal that all was not well with the industry. Leonora's demise was followed in 1987 by the closure of Diamond Sugar Estate. As of May 1992, only eight sugar estates were in operation in the entire country. Rice, the second most important agricultural product, 
has also performed poorly. Output in 1970 was 142,000 tons. A peak production of 210,000 tons was reached in 1977 , but by 1989 output was down to 140,000 tons, or 2,000 tons below the 1970 level. The decline in production, as well as acreage, may be attributed to many of the same problems associated with the sugar industry. In addition, rice farmers complain that the Guyana Rice Board, which controls the industry, has been not only inept, but dishonest in its grading, pricing, and weighing of their produce.?

Bauxite has been the most important mineral exploited in Guyana, and for a time in the 1970s it was the most dynamic component in the economy. In 1970, peak outputs of dried bauxite ( 2.3 million tons) and alumina (312,000 tons) were achieved, while calcined bauxite (778,000 tons) achieved its peak production in 1975. The level of production for dried bauxite in 1989 was one million tons, or 43 percent less than the peak output of 1970, whilst calcined bauxite's production was 294,000 tons, or 38 percent less than the peak output of 1975. Production of alumina was suspended in 1982 .

since nationalization, the bauxite industry has had to contend with managerial, financing, marketing, and labor problems that have adversely affected production. Key

\footnotetext{
${ }^{7}$ De Caires, D. 1988. "Guyana After Burnham: A new era? or is President Hoyte Trapped in the Skin of the old PNC? Caribbean Affairs 1 (1), p. 193; Singh, C. 1988. Guyana: Politics in a Plantation Society. New York: Praeger, p. 112.
} 
inputs such as fuel, oil, and caustic soda have increased, and the industry has had to pay high freight rates for inputs. The depressed state of the world market for aluminum also softened prices for bauxite, and this depreciation has been especially troubling since Guyana is a high-cost producer owing to the nature of bauxite deposits. The ore has to be mined from about 200 feet under an overburden of sand and clay, thus increasing the cost of extraction. The relative difficulty of reaching the deposits, is however, compensated for by the size of the ore bodies, which are unusually large, and the high-alumina/lowiron content which is best suited to the production of calcined bauxite, for which Guyana holds a virtual monopoly. Calcined bauxite, after application of intense heat, is used to manufacture abrasives and refractory brick for high-temperature kilns. The product was widely viewed as the future of the industry in Guyana, but unreliability of supplies to custorners has made the country a supplier of last resort. The country had 85 percent of the world market in 1975, but then its market share fell to 57 percent in 1984, as purchasers began to experiment with substitutes, adopt new technologies, and accept lower-quality ores from other countries. ${ }^{8}$ As a result, Guyana has been forced to produce dried bauxite - the least valuable product of the industry.

${ }^{8} J$ effrey and Baber 1986, op. cit., p. 146. 


\section{Labor Supply}

The absence of change in the industrial structure is evident in the data on the country's labor supply. Nevertheless, the sectoral composition of the labor force has not been entirely static. This section discusses some of these changes. Specifically, it addresses the expansion of public sector employment, and the growth of the informal labor force which took place following the economic difficulties of the late 1970s.

The Manpower Survey in 1965 estimated that there were some 193,048 persons in the labor force in that year, or about 31 percent of the population, excluding Amerindians; ${ }^{9}$ of this number 165,912 were employed, implying that slightly over 14 percent of the labor force was unemployed (Table XXIX). However, the manpower survey placed the unemployment rate at 16 percent and attributed the much higher unemployment ratio to seasonal factors. ${ }^{10}$ of the unemployed, the highest incidence was found in Georgetown and New Amsterdam, among females and younger groups with limited training and experience.

By 1970, the labor force had grown to 210,000 persons, while the number of those employed had declined to 162,000 . Consequently, the unemployment rate had increased to 23

\footnotetext{
${ }^{9}$ Francis 1966, op. cit.

${ }^{10}$ Ibid., Tables 1.1 and 1.2 .
} 
percent of the labor force. Although the actual labor force in 1970 was 210,000 , or 30 percent of the total population, the figure excluded half of the working population, or 223,000 persons; of these, 178,000 were females. The labor participation rate of females in 1970 was only 18 percent, while that of males was 47 percent.

TABLE XXIX

SECTORAL DISTRIBUTION OF LABOR FORCE 1965-1980

$\begin{array}{lcc} & \underline{1965} & \underline{1970} \\ \text { Labor force } & 193,048 & 210,000 \\ \text { Employed } & 165,912 & 162,000 \\ & & \% \\ \text { Industries } & \% & 29.0 \\ \text { Agriculture } & 34.9 & 4.9 \\ \text { Mining } & 3.1 & 15.0 \\ \text { Manufacturing } & 16.2 & 49.0 \\ \text { Services } & 45.8 & 23.0 \\ \text { Unemployment } & 14.1 & \\ \text { (\% of labor force) } & & \end{array}$

Sources: Jameson 1980; Manpower Survey 1965.

A look at the data on the sectoral shares of employment indicates the minimal structural change in the economy (Table XXIX). Two major sectors - agriculture and services - remained the major labor-absorbing industries. However, agricultural employment fell from a 35 percent share in 1965 to 29 percent in 1970, while service employment rose from 46 percent to 49 percent.

In 1970, sugar accounted for about one-third of the agricultural labor force - employing slightly over 17,000 workers. Since independence, employment in sugar has held 
relatively steady. Some decline was observed among factory workers, but this was compensated for by a slight increase in field employment (Table $\mathrm{XXX}$ ).

TABLE XXX

SUGAR ESTATE EMPLOYMENT 1966-1970

$\begin{array}{lccr}\text { Year } & \text { Field Workers } & \text { Factory workers } & \text { Total } \\ 1966 & 13,262 & 3,663 & 16,925 \\ 1967 & 13,597 & 3,545 & 17,142 \\ 1968 & 13,992 & 3,619 & 17,611 \\ 1969 & 14,553 & 3,287 & 17,840 \\ 1970 & 14,100 & 3,140 & 17,240\end{array}$

Source: Sukdeo 1975, pp. 238-240.

Rice was the second most important agricultural product, but employment estimates of this component are difficult to ascertain. In 1970, it was estimated that 45,000 families were concerned with rice production, and most of this group were dependent on the staple as a major source of income and livelihood."

Although the bauxite industry was a dynamic sector of the economy in 1970, it failed to create significant employment opportunities. Between 1965 and 1970, mining's share of sectoral employment increased marginally from 3 percent to 5 percent (Table XXIX). Very few linkages had been created with other sectors of the economy. The smelting of aluminum had been investigated, and it was hoped

"Jameson, K. and F. Bonello. 1978. A Macroeconomic Assessment of the Economy of Guyana. pp. 33-34. 
that significant employment opportunities would be created in fabricating industries which would utilize the smelter's output to produce wares, tubes, rods, wire, sheets, and foil. However, whilst the feasibility of the project was established, the government failed to garner the requisite funds to secure the project.

The failure to establish an aluminum smelter highlights the country's low level of industrialization. The sectoral employment share in manufacturing was 16 percent in 1965; and by 1970, it had fallen to 15 percent. The sectoral distribution of the labor force between 1970 and 1980 refiects the overall increase in the proportion employed in services, from 49 percent to 52 percent (Table XXIX). This is in keeping with the expansion of the public sector which took place in the 1970 s when the government embarked upon a cooperative developmental policy. Relatively high proportions of females are employed in the service industries, including the civil service and community services such as education and health. Comparing the occupational status of the economically active population, one is struck by the difference in proportions that worked for government as opposed to private enterprise between the 1970 and 1980 censuses (Table XXXI). In 1970 only 19 percent worked for government and 45 percent in the private sector, whereas in 1980 the figures were almost reversed: 43 percent worked for government and 20 
percent in private enterprise. Occupational status

distribution by gender over the 1970 and 1980 censuses indicates that the proportions of both groups that worked for others were relatively close, but a higher proportion of males were self-employed, whereas a higher proportion of females were unemployed.

TABLE XXXI

OCCUPATIONAL STATUS OF THE ECONOMICALIY ACTIVE POPULATION occupational status

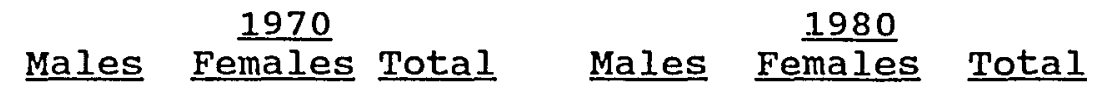
Worked for others govt 66.2 17.4 $65.6 \quad 65.9$ 66.2 44.4 20.0 private sec.

47.1 $21.6 \quad 19.5$ $42.2 \quad 44.7$ unpaid worker 1.7

$1.7 \quad 1.7$ 1.8

$\begin{array}{rr}63.9 & 65.0 \\ 41.4 & 42.9 \\ 20.5 & 20.2 \\ 2.0 & 1.9\end{array}$

Has own business

or farm $17.5 \quad 12.0 \quad 14.8$

15.9

9.6 12.8

Did no work $15.8 \quad 21.9 \quad 18.9$

15.8 $23.4 \quad 19.6$

Not stated $0.4 \quad 0.4 \quad 0.4$

2.1

3.1

2.6

Sources: 1970 census; 1980 census.

The agriculture industry continued to employ the second-largest share of the economically active population in 1980 - 50,316 persons, or 27 percent of the labor force. Since independence, the proportion employed in agriculture has continued to fall. However, the sugar industry, the sector's largest component, witnessed an increase in its labor force during the 1970s. Employment in sugar increased from 17,240 persons in 1970 , to 31,128 in 1980 , with much of 
the increase coming after nationalization in 1976 (Table XXXII). The importance of the industry was such that according to one estimate, in 1980, roughly 150,000 people were in some way dependent on sugar for their livelihood.12

TABLE XXXII

SUGAR ESTATE EMPLOYMENT 1970-1982

Year

1970

1971

1972

1976

1977

1978

1979

1980

1981

1982
Field and Factory Workers

17,240

17,521

17,394

28,406

33,545

31,651

33,067

31,128

31,374

28,077

Sources: Sukdeo 1975, pp.238-240;

Collymore 1984, p.29.

Since 1976, employment in the sugar industry has been rather unsteady, although an initial glance at the data reflects an upward trend, at least until 1982. In 1977, the industry was hit by a 135-day strike that was called in response to the refusal of the government to pay 238.9 million dollars in a profit-sharing scheme with the workers. In response, the government hired 6,132 strike-breakers and granted them permanent positions. ${ }^{13}$ Therefore, at the end

\footnotetext{
${ }^{12}$ Shahabuddeen 1983 , op. cit., p. 49.

${ }^{13}$ Collymore, C. 1984 . Bitter Sugar and the Working People.
} p. 28 . 
of 1977, the work force should have been around 34,500 ;

however, the industry reported a total of only 33,545

workers. The government had thus used the strike to dismiss almost 1,000 workers.

During 1981-1982 the sugar industry lessened its work force by nearly 12 percent when it laid off 3,297 workers as part of a retrenchment program to satisfy the IMF. The retrenchment program took place in the midst of high unemployment rates that were prevailing in the country. Retrenchment of workers was not confined to sugar; it also included the gamut of organizations, corporations, and companies run by the state. The state, rather than transnationals or a hegemonic power, was now manipulating the country's labor supply to preserve or increase the rate of exploitation. The unemployed constituted an industrial reserve army to be used by any sudden expansion of capitalist production.

Whilst all workers have borne the injustices of state capitalism, those in sugar have been hit particularly hard. Wages of sugar workers have historically been low when compared with those of other industries. It was hoped that with nationalization, relations of production would change and workers would be rewarded for the fruits of their labor. However, this was not to be the case, and wage rates have lagged the inflation rate for much of the period. But given the difficulties in securing employment in Guyana, the 
industry has been able to dictate wage rates without fear of interrupting its supply of labor.

With the increase in economic dislocation in the late 1970s and the government's attempts at corrective measures, an ever-increasing number of the population have been forced into activities outside the formal labor force. Many workers are now engaged in small-scale trading, smuggling, and other petty-commodity production activities (the socalled informal economy beyond government control). According to some estimates, the informal economy accounted for 70-80 percent of the GDP in 1987 and was nearly as large as the formal economy. ${ }^{14}$

A high proportion of those involved in the informal economy are women. ${ }^{15}$ Women are dominant in what is known as the "suitcase economy" or "international trading," an activity which became noticeable around $1978 .^{16}$ Traders in this segment of the informal economy are identified by their commodious striped polytene bags and cavernous suitcases, and are found in just about every airport of the region. They smuggle out gold, jewellery, foreign currency, and local goods and crafts, and bring in items that are deemed

${ }^{14}$ Danns, G. n.d. "The Underground Economy and the state in Guyana - A Synopsis." Unpublished paper (University of Guyana), p. 13 .

${ }^{15}$ Economist Intelligence Unit. 1988. Country Profile. Guyana, Barbados, Windward \& Leeward Islands. London: EIU, p. 14 .

\footnotetext{
${ }^{16}$ Danns n.d, op. cit., p. 17.
} 
to be in short supply, which in the 1980s was just about every conceivable item. ${ }^{17}$

\section{DEMOGRAPHY}

This portion of the chapter traces the components and trends of population growth and distribution since independence. In addition to births, deaths, and ruralurban migration, it closely examines the impact of emigration on urbanization. For instance, how has emigration affected the racial composition of the population? What became of whites and Chinese? The focal point of the study's demographic structure remains Georgetown and its junior urban partner, New Amsterdam; but newer designated urban areas to the settlement hierarchy such as Rose Hall, Corriverton, and Linden - are surveyed. The creation of a regional system of administration and the resultant generation of a rich body of regional data also allows one to pursue a regional comparative analysis of the demographic structure. This ought to be particularly helpful in the subsequent section when the study attempts to assess infrastructure provision and expenditure patterns. During the intercensal period 1960-1970, the population of the country increased by 139,518 , or 25.2 percent, reflecting a growth rate of 2.25 percent per annum (Table XXXIII). These rates are much lower than the 3.3

\footnotetext{
${ }^{17}$ Ibid., pp. 17-19.
} 
percent per annum growth observed during 1950-1960. The slower growth rate in the 1960 s is attributed to a number of factors, not the least of which was the continuing emigration to metropolitan countries.

TABLE XXXIII

POPULATION DISTRIBUTION 1960-1980

Year Guyana Georgetown $\%$ N/Amsterdam $\frac{\%}{\underline{\sigma}}$ Urban $\begin{array}{llllllll}1960 & 560,330 & 148,391 & 26.5 & 14,053 & 2.5 & 162,444 & 29.0\end{array}$

$\begin{array}{llllllll}1970 & 701,718 & 164,039 & 23.4 & 17,782 & 2.5 & 223,212^{1} & 31.8\end{array}$

$\begin{array}{llllllll}1980 & 759,567 & 167,839 & 22.1 & 19,287 & 2.5 & 235,126 & 31.0\end{array}$

Sources: Census 1970; Census of the Commonwealth Caribbean 1980-1981.

1. Corriverton, Rose Hall, and Linden were designated urban areas, under the Municipal and District Councils Act of 1969 .

A conservative estimate of population movements between 1965 and 1969 suggested that net emigration averaged 2,200 persons per annum. ${ }^{18}$ Furthermore, it was noted that a majority of the emigrants were experienced and skilled, with above-average training. ${ }^{19}$ This migration aggravated the acute shortage of skilled labor in the country, and because mostly males emigrated, there was also a steady decline in the gender ratio (Table XXXIV).

In addition to emigration, births and deaths

${ }^{18}$ IBRD. 1970. Current Economic Position and Prospects of Guyana. Vol. I. Main Report. Central America and Caribbean Department, p. 29.

${ }^{19}$ Ibid., p. 31. 
constitute the prime determinants of population growth in Guyana. Between 1960 and 1970, the average natural increase of the population (that is, the difference between the average birth rate and the average death rate) declined from

TABLE XXXIV

GENDER RATIO 1960-1989

$\begin{array}{lllll}\text { Year } & \text { Male } & \text { Female } & \text { Total } & \text { Gender Ratio } \\ 1960 & 279,128 & 281,202 & 560,330 & 0.99 \\ 1970 & 349,143 & 352,575 & 701,718 & 0.99 \\ 1980 & 376,381 & 383,186 & 759,567 & 0.98 \\ 1989 & 373,900 & 381,300 & 755,200 & 0.98\end{array}$

Sources: Censuses 1960-1970; Census of the

Commonwealth Caribbean 1980; Statistical Digest 1989.

32.3 per thousand to 26.9 per thousand. over this period the birth rate per annum declined from 43.3 per thousand to 33.8 per thousand, whilst the deain rate declined from 10.4 per thousand to 6.9 per thousand. Thus, the pronounced decline in the birth rate combined with the emigration figures and the modest decline in the death rate to produce the slow overall growth of the population.

The distribution of the population in 1970 indicates that there were 223,212 persons out of a total of 701,718 living in urban areas (Table XXXIII). Although this figure represented some growth in the urban population over the 1960 census, the 2.8 percent increase is slight when one considers that Corriverton (population 12,417), Rose Hall 
(population 5,018), and Linden (population 23,956) were accorded urban status in 1970. If the populations of these three newly designated urban areas are excluded from the urban total for 1970, the proportion of the population living in urban areas would register a decline of 3.1 percent during the intercensal period.

In 1970, Georgetown, the capital city, had an estimated population of 164,034 , which represented a growth rate of a little over 1 percent for the decennium (Table XXXIII). The low rate of increase in Georgetown was attributable to primarily three factors. Firstly, the capital had a low rate of natural increase - according to the 1970 census, 38 percent of all women in the childbearing age group (15-44 years) had no children. Secondly, the 1965 Manpower Survey surmised that among those who emigrated, many more left from urban than from the rural areas. ${ }^{20}$ and, thirdly, the disturbances of the early 1960s hindered movement into the capital and at the same time encouraged movement outward. ${ }^{21}$

Within the city proper, the population between 1960 and 1970 decreased by 9,780 (13.4 percent) from 72,964 to 63,184 , while the population in the suburbs of Georgetown increased by 25,428 (33.7 percent) from 75,427 to 100,855 . This internal redistribution of population was undoubtedly

\footnotetext{
${ }^{20}$ Francis 1966, op. cit., p. 25.

${ }^{21}$ Ibid.
} 
related to out-migration from the central city as well as the rural areas. Migration to the suburbs was also influenced by the establishment of the University of Guyana, at Turkeyen. ${ }^{22}$

Despite the slowdown in the growth of Georgetown over the decade, the city nevertheless dominated the settlement hierarchy. This domination is emphasized by the fact that, in $1970,370,000$ people (over 50 percent of the total population) were contained within a 25 -mile radius of the city. ${ }^{23}$ The city was 6.8 times the size of Linden and 9.2 times the size of New Amsterdam. Linden, formed by the amaigamation of Mackenzie, Christianburg, and Wismar, had overtaken New Amsterdam as the nation's second-largest urban center.

New Amsterdam registered an increase in population of 3,729 or 26.5 percent, over the period. The increase was slightly above the overall rate for the country $(25.2$ percent). However, East Berbice, the portion of the county in which New Amsterdam is located, realized a percentage increase of more than 30 percent. This high rate of increase in East Berbice seemed to be related to migration

${ }^{22}$ The University of Guyana was founded in 1963 in Georgetown. It began life as an evening college and was disparagingly referred to by some as "Jagan's Night School." In 1973, following the move to Turkeyen, it began to admit full time students.

${ }^{23}$ Central Transport Planning Unit. 1975. Transport Plan for Guyana, p. 16 . 
that was influenced by the establishment of land settlement schemes such as Black Bush Polder (1960), Brandwagt/Sari (1963), and Mara (1957). The higher fertility rates of the Indian population which predominated the area was another likely factor which accounted for the differences in population growth between New Amsterdam and East Berbice. In 1970, Indians were largely in the rural areas, as they have been since indentureship, while African-descended segments of the population were clustered in the urban centers (Table XXXV).

TABLE XXXV

RACIAL DISTRIBUTION OF THE POPULATION 1970

Race Urban $\frac{\% \text { of }}{\text { Race }} \stackrel{\% \text { of Pop. of }}{\text { Urban area }}$ Rural $\stackrel{\% \text { of }}{\text { Race }} \frac{\% \text { of Pop.of }}{\text { Rural area }}$

$\begin{array}{lllllll}\text { Indian } & 48,861 & 13.5 & 23.2 & 311,875 & 86.5 & 64.2\end{array}$

$\begin{array}{lllllll}\text { African } & 113,497 & 52.0 & 53.8 & 104,904 & 48.0 & 21.4\end{array}$

$\begin{array}{lllllll}\text { Chinese } & 2,597 & 76.3 & 1.2 & 805 & 23.7 & 0.2\end{array}$

$\begin{array}{lllllll}\text { AmerIndn. } & 1,856 & 5.4 & 0.9 & 32,446 & 94.6 & 6.6\end{array}$

$\begin{array}{lllllll}\text { White } & 1,656 & 75.8 & 0.8 & 530 & 24.2 & 0.1\end{array}$

$\begin{array}{lllllll}\text { Mixed } & 37,675 & 52.1 & 17.9 & 34,642 & 47.9 & 7.1\end{array}$

$\begin{array}{lllllll}\text { Others }^{1} & 4,337 & 72.3 & 2.1 & 1,661 & 27.7 & 0.3\end{array}$

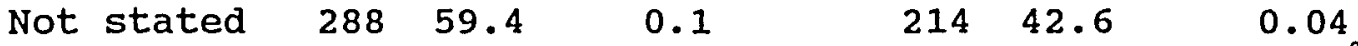

$\begin{array}{lllllll}\text { Total } & 210,767 & 30.1 & 100.0 & 489,077 & 69.9 & 99.94^{2}\end{array}$

Sources: Census 1970; Jones 1981 (Table 1.2) p. 9.

1. Includes Portuguese.

2. Rounding accounts for deviations from 100 .

The racial composition of the population in 1970 shows that Indians were in the majority with 51.8 percent of the population (Table XXXVI). Since 1960, Indians had increased their share of the population by nearly 4 percent, whilst 
Africans, the second-largest group, had registered a decline in their share by almost 2 percent.

TABLE XXXVI

RACIAL COMPOSITION OF THE POPULATION 1960-1986

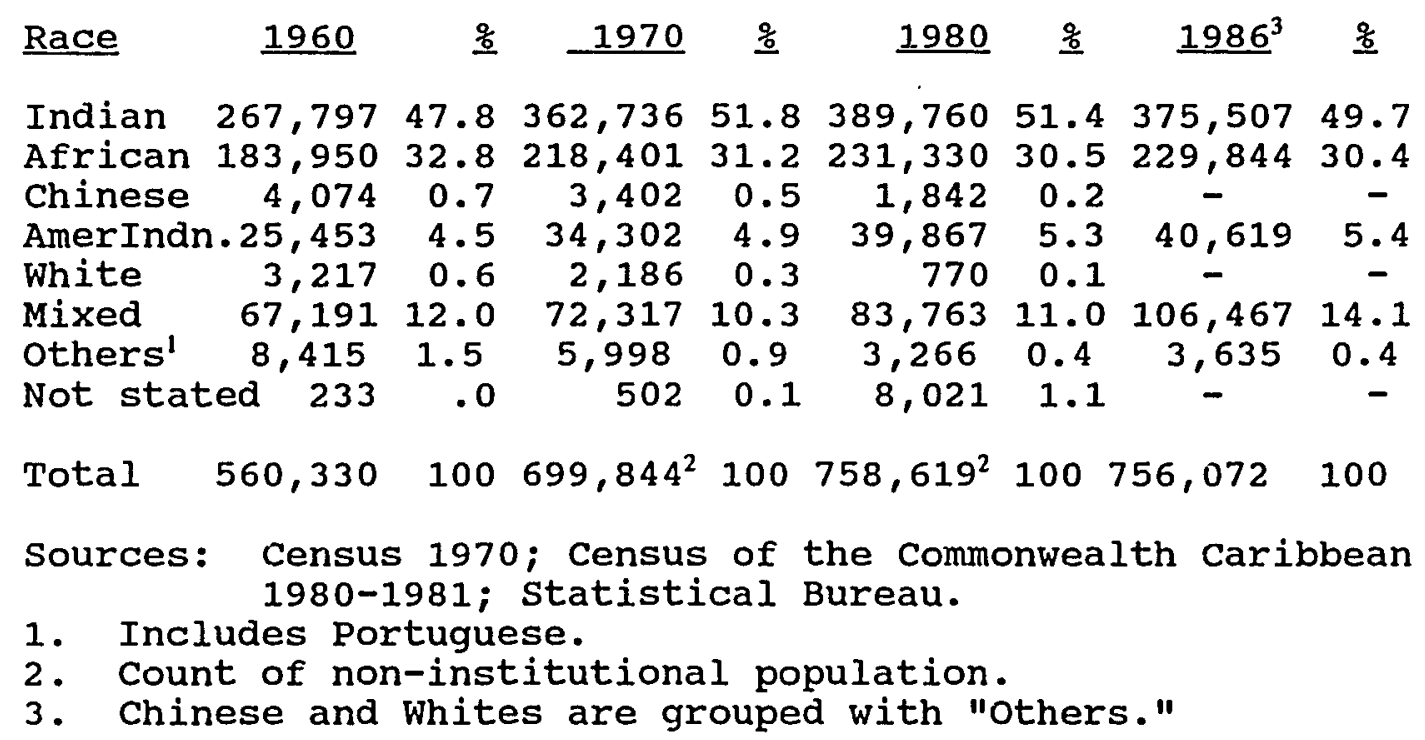

Indians, Africans, Amerindians, and the Mixed group steadily increased in numbers up to the 1980 census. The fastest growth rates were experienced by the Amerindians, who increased by 16.2 percent between 1970 and 1980 . They were closely followed by the Mixed group, whose intercensal growth was 15.8 percent, whereas the increase for Indians was 7.4 percent, and for Africans 5.9 percent. The rapid growth of the Amerindians was due in part to declining mortality accompanied by sustained high fertility among the race, but it may also have been due in part to better data collection by census takers in the interior where the 
Amerindians live.

Perhaps the most noticeable feature of the country's racial composition since independence has been the severe reduction in the numbers of Chinese and whites. Between 1960 and 1980, the chinese population was reduced by 55 percent and whites by 76 percent. Most of the decline of the two groups took place during the 1970-1980 period, and the timing leads one to suspect that emigration was the major contributor to the loss of population. Certainly, intermarriage may be responsible for some of the losses of both minority groups, but the reductions are so large that this is highly unlikely to be the only factor. In more recent times, the numbers of Chinese and whites have been so insignificant that they are no longer classified separately. Emigration cuts across all racial groups. Whereas during the 1960-1970 census interval the population increased by 141,388 , the increase from 1970 to 1980 was only 57,849. The level of emigration is apparent when one considers that for the 1970-1980 period the number of births totalled 238,450 and the number of deaths 57,690, indicating a natural increase of 180,760 . This increase implies that 121,911 persons departed the country during the decennium an astonishing number for a country whose total population in 1980 was 759,567 . Although more males than females left during this period, the emigration ratios for the groups were much closer than in the past when males had dominated 
(Table XXXVII)

TABLE XXXVII

COMPONENTS OF POPULATION CHANGE 1970-1980

$\begin{array}{lrrr} & \text { Males } & \text { Females } & \text { Total } \\ \text { Population in 1970 } & 349,143 & 352,575 & 701,718 \\ \text { Population in 1980 } & 376,381 & 383,186 & 759,567 \\ \text { Intercensal change } & 27,238 & 30,611 & 57,849 \\ & & & \\ \text { Births 1970-1980 } & 120,850 & 117,600 & 238,450 \\ \text { Deaths 1970-1980 } & 31,900 & 25,790 & 57,690 \\ \text { Natural increase } & 88,950 & 91,810 & 180,760 \\ \text { Implied emigration } & -61,712 & -61,199 & -122,911\end{array}$

Source: Census of the Commonwealth Caribbean 1980-1981.

The country's population distribution remained relatively unchanged throughout the decade of the 1970 s. Georgetown, with a population of 167,839 in 1980, increased its population by 3,800 , or 2.3 percent, whilst New Amsterdam's population rose by 1,505, or 8.5 percent. Overall, Georgetown's share of the country's total population declined from 23.4 percent to 22.1 percent. The city was still overwhelmingly the largest settlement and was still attracting internal migrants. In 1980, over 42 percent of Georgetown's population were born in other parts of the country (Table XXXVIII). New Amsterdam, the EcclesSoesdyke district (on East Bank Demerara between Georgetown and Timheri International Airport), Upper Demerara (Linden), and Mazaruni-Potaro (a mining district) also have high proportions of their populations who were born elsewhere in the country. 
TABLE XXXVIII

AREAS OF RESIDENCE AND BIRTHPLACES OF POPULATION 1980

Area of Birth

\begin{tabular}{|c|c|c|c|c|}
\hline \multicolumn{2}{|c|}{ Area of } & Elsewhere & outside & Total Nos. \\
\hline Place & Residence & in country & Country & $(=100 \%)$ \\
\hline Georgetown & 56.2 & 42.2 & 1.6 & 167,839 \\
\hline New Amsterdam & 61.2 & 37.9 & 1.0 & 19,287 \\
\hline Eccles-Soesdyke & 62.6 & 36.4 & 0.9 & 42,329 \\
\hline Indst.-La Recns. & 84.3 & 15.4 & 0.4 & 121,335 \\
\hline West Berbice & 89.1 & 10.9 & .0 & 36,342 \\
\hline East Berbice & 91.2 & 8.2 & 0.5 & 138,528 \\
\hline Upper Dem. River & 54.9 & 43.4 & 1.7 & 36,678 \\
\hline West Demerara & 83.6 & 16.1 & 0.3 & 86,886 \\
\hline Pmrn-Smrs-Brk & 91.0 & 9.0 & .0 & 58,586 \\
\hline N.W. District & 88.0 & 11.6 & 0.5 & 18,297 \\
\hline Mazaruni-Potaro & 57.8 & 36.2 & 6.0 & 16,335 \\
\hline Rupununi & 91.5 & 7.4 & 1.1 & 16,177 \\
\hline Guyana & 99.2 & 0.0 & 0.8 & 758,619 \\
\hline
\end{tabular}

Source: Census of the Commonwealth Caribbean 1980-1981.

Assessing internal migration in Guyana is a hazardous business. It does not appear to be a one-step process, and migration cannot be seen in unidirectional terms by which people move only from rural to urban areas. This is highlighted in Table XXXIX, which shows that areas such as Georgetown and New Amsterdam, which have large proportions of their populations born elsewhere in the country, are also areas which have lost a good deal of their native-born populations to other areas in the country. For example, over one-third of the people who were born in Georgetown (34 percent) and New Amsterdam (38 percent) resided in another part of the country in 1980 . 
TABLE XXXIX

PLACE OF BIRTH AND AREA OF RESIDENCE OF POPULATION 1980

Area of Residence $(\%)$

Place

Georgetown

New Amsterdam

Eccles-Soesdyke

Indust.-La Recns.

West Berbice

East Berbice

Upper Dem. River

West Demerara

Pmrn-Smrs-Brk.

N.W. District

Mazaruni-Potaro

Rupununi

Not stated

Guyana

Source: Census of the Commonwealth Caribbean 1980-1981.
Total

$\frac{\text { Place of }}{\text { Birth }} \quad \underline{\text { Elsewhere }} \quad \frac{\text { Total }}{\text { in country }}$

66.0

62.0

34.0

38.0

140,168

19,025

79.2

20.8

19.1

27.7

12.1

22.9

17.9

28.9

22.5

20.7

5.1

33,454

126,336

44,808

143,781

26,130

88,464

75,019

20,768

11,904

15,601

6,759

752,217

The results of the 1990 census have not, at the time of this writing, been made available to the public. However, in 1986, the statistical Bureau estimated the population to be 756,072 , or a decline of 3,495 persons $(.5$ percent) over the 1980 census. This was the first recorded decline of the total population since census collection began in 1841. Low fertility and massive emigration were the likely causes of the reduction. Fertility in Guyana has been steadily declining. According to statistical Bureau figures, the fertility rate for women in the reproductive age group (14-49) was 2.6 children per woman, whilst the overall average number of children born to all women was 
slightly higher, at 2.8 per woman. Among women under 23 years of age, the average number of children was below one a clear indication of the continuing decline in fertility observed in the post-independence era.

Fertility differentials among the races also display recent changes. Indian women, who in the past have traditionally exhibited higher fertility rates than the African and Mixed groups, are now showing fertility levels that are similar to those of these two major groups. Fertility rates, however, remain relatively high among Amerindian women (Table XL).

TABLE XL

FERTILITY RATES BY RACE FOR FEMALE POPULATION 14-49 YEARS 1986

Race

\begin{tabular}{|c|c|c|c|c|}
\hline Age Group & Indian & African & Mixed & Amerindian \\
\hline-14 & .02 & .00 & .00 & .03 \\
\hline $15-19$ & .12 & .17 & .22 & .40 \\
\hline $20-24$ & .80 & .93 & 1.00 & 1.70 \\
\hline $25-29$ & 1.95 & 1.88 & 2.03 & 3.14 \\
\hline $30-34$ & 3.41 & 3.17 & 3.35 & 4.42 \\
\hline $35-39$ & 4.06 & 4.07 & 4.80 & 6.26 \\
\hline $40-44$ & 5.32 & 4.90 & 5.07 & 7.51 \\
\hline $45-49$ & 7.01 & 6.10 & 6.03 & 8.00 \\
\hline Total & 2.22 & 2.11 & 1.96 & 3.31 \\
\hline
\end{tabular}

Source: Statistical Bureau 1987.

Emigration, another major reason for the decline in population, was very high during the statistical Bureau's survey period (1981-1986) (Table XLI). Between 1981 and 1986, approximately 31,808 persons departed Guyana for permanent residence abroad. Looking at those who emigrated, 
it is noticeable that in every year, females (53.8 percent) outnumbered males (46.2 percent). Furthermore, emigration was age-selective, with just over 65 percent of emigrants being in the highly reproductive age group of 15-34 years of age. The highest number of emigrants were reported as having departed the country in 1986 (7,682 persons), but this figure may well have been a function of respondent recall and reporting, rather than any differential in outflow. The statistical Bureau's figures are also probably on the conservative side, since family emigration has become commonplace and some emigrants may have no family members left in Guyana to report on their behalf. This aspect of emigration is especially noticeable in the villages of Corentyne, Berbice, where row upon row of houses have been boarded up by owners who have left for foreign climes. Underestimation of the number of emigrants may also be attributed to illegal emigration and withholding of information by respondents.

Population distribution data in 1986 are not directly comparable with those in previous surveys, since the newly provided figures are based on regions and are not broken down by individual settlements (Figure 4). As Table XLII shows, over one-quarter (28.3 percent, or 214,027 persons) of the country's population were living in urban areas; however, there is no information on the population levels of each of Guyana's five urban centers - Georgetown, Linden, 
New Amsterdam, Rose Hall, and Corriverton.

TABLE XLI

EMIGRATION BY AGE GROUP, GENDER AND YEAR OF DEPARTURE 1981-1986

\begin{tabular}{|c|c|c|c|c|c|c|c|c|c|c|c|c|c|}
\hline \multirow[b]{3}{*}{ Age } & \multirow[b]{3}{*}{ Tot } & & & & & \multicolumn{8}{|c|}{ Year of Departure } \\
\hline & & \multicolumn{2}{|c|}{$\underline{1981}$} & \multicolumn{2}{|c|}{$\underline{1982}$} & \multicolumn{2}{|c|}{1983} & \multicolumn{2}{|c|}{1984} & \multicolumn{2}{|c|}{1985} & \multicolumn{2}{|c|}{1986} \\
\hline & & $\underline{M}$ & $\underline{\mathbf{F}}$ & $\underline{\mathbf{M}}$ & $\underline{F}$ & $\underline{M}$ & $\underline{F}$ & $\underline{\mathbf{M}}$ & $\underline{F}$ & $\underline{M}$ & $\underline{\mathbf{F}}$ & $\underline{\mathbf{M}}$ & $\underline{\mathbf{F}}$ \\
\hline $0-4$ & 438 & 0 & 0 & 35 & 60 & 34 & 47 & 20 & 40 & 20 & 20 & 101 & 61 \\
\hline $5-9$ & 1135 & 0 & 21 & 129 & 55 & 93 & 108 & 60 & 191 & 95 & 54 & 132 & 197 \\
\hline $10-14$ & 2176 & 102 & 141 & 202 & 110 & 189 & 122 & 160 & 213 & 119 & 285 & 194 & 339 \\
\hline $15-19$ & 5501 & 121 & 371 & 450 & 398 & 413 & 585 & 467 & 519 & 480 & 517 & 533 & 647 \\
\hline $20-24$ & 7340 & 72 & 331 & 482 & 722 & 990 & 791 & 485 & 584 & 566 & 685 & 621 & 1011 \\
\hline $5-29$ & 5408 & 208 & 232 & 394 & 525 & 477 & 693 & 357 & 379 & 415 & 484 & 656 & 588 \\
\hline $30-34$ & 2599 & 75 & 78 & 218 & 180 & 395 & 236 & 225 & 172 & 247 & 233 & 304 & 236 \\
\hline $35-39$ & 1622 & 121 & 39 & 93 & 53 & 142 & 239 & 94 & 172 & 136 & 130 & 209 & 194 \\
\hline $40-44$ & $14 I 3$ & 59 & 40 & 100 & 39 & 160 & 166 & 210 & 122 & 47 & 21 & 209 & 141 \\
\hline 45 & 923 & 21 & 21 & 61 & 97 & 103 & 118 & 55 & 53 & 93 & 110 & 72 & 119 \\
\hline & 958 & 21 & 15 & 41 & 59 & 56 & 21 & 79 & 137 & 85 & 92 & 112 & 240 \\
\hline & 925 & 14 & 34 & 73 & 95 & 20 & 60 & 19 & 89 & 58 & 154 & 147 & 162 \\
\hline $0-6$ & 659 & 20 & 33 & 14 & 42 & 0 & 95 & 0 & 20 & 154 & 121 & 100 & 60 \\
\hline & 442 & 0 & 0 & 41 & 41 & 38 & 0 & 40 & 40 & 0 & 42 & 119 & 81 \\
\hline & 184 & 0 & 0 & 20 & 0 & 0 & 40 & 20 & 42 & 0 & 41 & 21 & 0 \\
\hline & 88 & 0 & 0 & 0 & 0 & 0 & 53 & 0 & 0 & 0 & 0 & 21 & 14 \\
\hline & 76 & 0 & 0 & 0 & 0 & 21 & 14 & 0 & 0 & 0 & 0 & 20 & 21 \\
\hline $85+$ & 20 & 0 & 0 & 0 & 0 & 0 & 0 & 0 & 0 & 0 & 20 & 0 & 0 \\
\hline
\end{tabular}

Tot. 31808

$\begin{array}{lrrrrrr} & 1981 & 1982 & \underline{1983} & \underline{1984} & \underline{1985} & \underline{1986} \\ \text { Male } & 834 & 2353 & 3131 & 2291 & 2515 & 3571 \\ \text { Female } & 1356 & 2476 & 3388 & 2773 & 3009 & 4111\end{array}$

Source: Statistical Bureau 1987.

Guyana's five urban centers - Georgetown, Linden, New Amsterdam, Rose Hall, and Corriverton - are located in three of the country's ten regions. Georgetown is the only urban center in Region 4 (Demerara/Mahaica), and Linden the only 


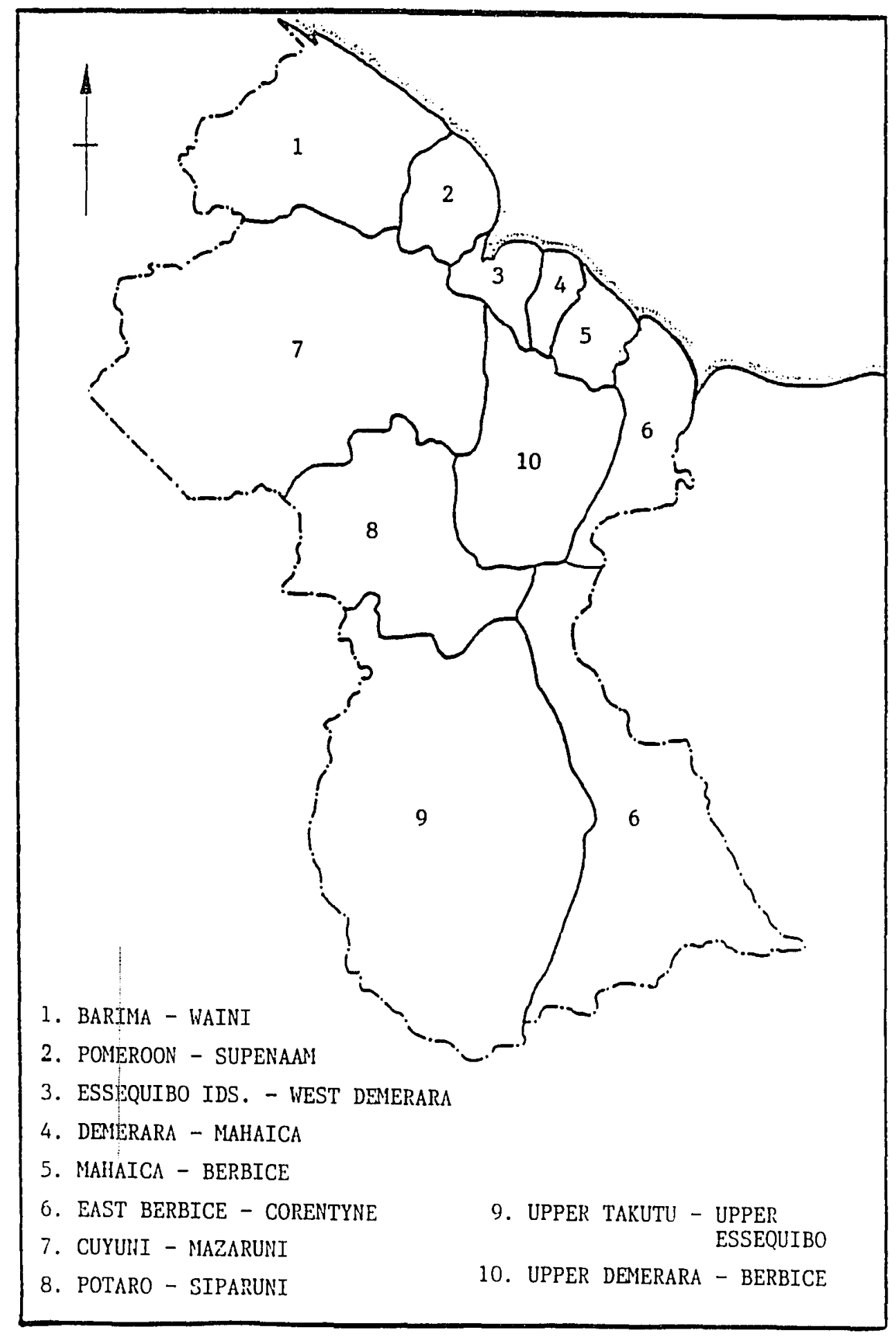

Figure 4. Administrative Regions of Guyana. 
TABLE XLII

URBAN AND RURAL POPULATION DISTRIBUTION BY REGION 1986 Region Population Urban $\%$ Rural $\frac{\%}{0}$

\begin{tabular}{|c|c|c|c|c|c|c|}
\hline eg. & arima/Waini & 18,516 & - & - & 18,516 & 100.0 \\
\hline eg. & Pomeroon/Supenaam & 41,966 & - & - & & 100.0 \\
\hline Reg. 3 & Essequibo/W. Dem. & 102,760 & - & - & 102,760 & 100.0 \\
\hline eg. 4 & Demerara/Mahaica & 310,758 & 150,368 & 48.4 & 160,390 & 51.6 \\
\hline eg. & Mahaica/Berbice & & - & - & & \\
\hline eg. 6 & E.Berbice/C'tyne & 148, & 34,623 & 23.2 & 114， & \\
\hline Reg. 7 & Cuyuni/Mazaruni & 17 & - & - & 17,941 & 100.0 \\
\hline Reg. 8 & Potaro/siparuni & 5, & - & - & 572 & 100.0 \\
\hline & Upp. Takutu/ & & & & & \\
\hline $\mathrm{eg} \cdot 10$ & Upp. Dem/Berbice & 38,598 & 29,036 & $7 \overline{5} .2$ & $\begin{array}{r}15,338 \\
9,562\end{array}$ & 24.8 \\
\hline & & & 4,0 & 28.3 & 542 & \\
\hline
\end{tabular}

Source: Statistical Bureau 1987.

center in Region 10 (Upper Demerara/Berbice), whilst New Amsterdam, Rose Hall, and Corriverton are all urban centers in Region 6 (East Berbice/Corentyne). Therefore, from the data in Table XLI, one is able to deduce the populations of Georgetown and Linden, and the combined population of New Amsterdam, Rose Hall, and Corriverton. Georgetown, with a population of 150,368 in 1986, witnessed a decline of 17,471 , or 10.4 percent of its population since the 1980 census, and a decline of 13,671 , or 8.3 percent, over the 1970 census. A slight decline in population was also noticed in the towns of East Berbice. During 1970 and 1986, New Amsterdam, Rose Hall, and Corriverton registered a loss of 592 , or 1.7 percent of their combined population. Conversely, Linden, whose population was fixed at 23,956 in 1970, saw its population increase by 5,080 , or 21.2 percent, 
between 1970 and 1986. Georgetown, nevertheless, accounted for just over 70 percent of the country's urban population and 20 percent of the country's total population, and was five times larger than Linden, the second most populated urban center in the settlement hierarchy. Whilst population figures for New Amsterdam are not available, it is observable that the town is being challenged by the two urban centers in Corentyne, Rose Hall, and corriverton. In particular, corriverton has been buoyed by trading activities with neighboring surinam. The banning of a range of consumer items in the 1970 s provoked a vigorous illicit trade with the former Dutch colony, and this trade has continued up to the present time as the local population has continued to respond to the endemic shortages of goods in the country in the 1980s and 1990s. Rose Hall too has benefitted from its proximity to surinam and has managed to share some of the spoils of the trade. However, the government's decision to revoke its list of banned consumer items has relaxed the Surinam-Corriverton/Rose Hall trading nexus, since goods can now freely enter through Georgetown.

of the regions in 1986, slightly more than 60 percent of the population were resident in Region 4 (Demerara/Mahaica) and Region 6 (East Berbice/Corentyne). By contrast Regions 1 (Pomeroon/Supenaam), 7 (Cuyuni/Mazaruni), 8 (Potaro/Siparuni), and 9 (Upper 
Takutu/Upper Essequibo) together accounted for less than 8 percent of the total population. The regions with defined coastal boundaries - Regions 2 (Pomeroon/Supenaam), 3 (Mahaica/Berbice), and 6 (E. Berbice/Corentyne) - were home to almost 90 percent of the country's population. There was very little intra-regional migration; just over 84 percent of the population still resided in their regions of birth (Table XLIII). The regions in the interior, 8 and 9, had the highest percentages of non-movers (95 percent), whilst the lowest percentages were found in Region 2 (73 percent) and Region 5 (75 percent).

\section{TABLE XLIII}

POPULATION BORN IN GUYANA BY REGION OF BIRTH: NON-MOVERS 1986

\section{Region Born in still Living in}

Reg. 1 Barima/Waini 21,022

Reg. 2 Pomeroon/Supenaam 53,354

Reg. 3 Essequibo/W.Dem. 112,938

Reg. 4 Demerara/Mahaica 282,068

Reg. 5 Mahaica/Berbice 60,447

Reg. 6 E.Berbice/C'tyne 159,099

Reg. 7 Cuyuni/Mazaruni 10,973

Reg. 8 Potaro/Siparuni 5,061

Reg. 9 Upp. Takutu/

Upp. Essequibo 14,691

Reg.10 Upp. Dem/Berbice 30,215

$\begin{array}{rr}16,434 & 78.2 \\ 38,898 & 72.9 \\ 87,672 & 77.6 \\ 252,843 & 89.6 \\ 45,601 & 75.4 \\ 138,364 & 87.0 \\ 9,482 & 86.4 \\ 4,794 & 94.7 \\ 14,032 & 95.5 \\ 23,226 & 76.9\end{array}$

$$
\text { Total } 749,868
$$

631,346

84.2

Source: Statistical Bureau 1986.

Though half the regions $(4,7,8,9$, and 10) were net recipients of populations, Region 4 was by far the most attractive, with 46 percent of the country's intra-regional 
migrants resident there (Table XLIV). Much of this attractiveness was undoubtedly due to the presence of Georgetown in the region. Although only about 7 percent of all lifetime migrants resided in Region 7, the migratory process was nonetheless very significant in this region and in Region 10. Lifetime migrants made up 46 percent of the total population of Region 7 and 39 percent of Region 10 . In more recent times, Regions 7 and 8 might have been attracting additional populations because of desperate times in Georgetown. A number of the African male population were migrating to the hinterland in search of productive employment in the mineral beit of the country - the BarticaPotaro area. By contrast, in Regions 2, 6, and 9, less than 8 percent of the population were born elsewhere.

TABLE XLIV

POPULATION BORN IN GUYANA BY REGION OF RESIDENCE: IN-MIGRANTS 1986

\section{Region}

Reg. 1 Barima/Waini

Reg. 2 Pomeroon/Supenaam

Reg. 3 Essequibo/W.Dem.

Reg. 4 Demerara/Mahaica

Reg. 5 Mahaica/Berbice

Reg. 6 E.Berbice/C'tyne

Reg. 7 Cuyuni/Mazaruni

Reg. 8 Potaro/siparuni

Reg. 9 Upp. Takutu/

Upp. Essequibo

Reg.10 Upp. Dem/Berbice

Total
Population
Born Elsewhere

1,958

3,024

14,634

54,185

9,881

9,846

8,213

658

$$
15,147
$$

38,234

749,868
1,115

15,008

118,522
음

10.6

7.2

14.2

17.4

17.8

6.6

45.8

11.6

7.3

38.9

15.8

Source: Statistical Bureau 1987. 
Since 1980, the Indian population has continued to decline. Between 1980 and 1986, the Indian population fell by 14,253 , or 3.7 percent, the largest absolute and percentage decline of any racial group in Guyana. Much of the decline can be attributed to the high rate of Indian emigration. Since 1970, when the PNC consolidated its hold on power in Guyana, Indians have comprised the bulk of the emigration stream, whereas in the past Africans were the overwhelming majority of emigrants.

Indians, however, were still the largest racial group in the country in 1986, accounting for slightly under half of the population. Africans, the second-largest group, comprised 30 percent of the population. Between 1980 and 1986, theix numbers had fallen slightly by 1,486 , or . 6 percent. By contrast, Amerindians had increased by 752 , or 1.9 percent, and the Mixed group by 22,704 , or by 21.3 percent. The increase in the Mixed population since the 1980 census appears to be inordinately high, and this figure may well be the result of more people reporting themselves or being reported as mixed.

A look at the racial distribution of the population by region in 1986 revealed that the majority of the Indian population, some 98 percent, resided in Regions 2, 3, 4, 5, and 6, with 33 percent in Region 4 and close to 30 percent in Region 6 (Table XLV). The African population revealed an even less-balanced spatial distribution than the Indian 
group; almost 60 percent resided in Region 4, which together with Regions 3, 5, 6, and 10 accounted for nearly 95 percent of the group. The Amerindian population was heavily concentrated in the interior and riverain areas, particularly in Regions 1, 2, 6, 8, and 9. Because of their high concentrations in remote areas of the country, Amerindians constituted majorities in Region 9 ( 83 percent), Region 8 ( 71 percent), and Region 1 (53 percent).

TABLE XLV

RACIAL DISTRIBUTION OF POPULATION BY REGION 1986

Region Indian African Mixed Am.Indn other Total

Reg. 1 Barima/ $\begin{array}{lllllll}\text { Waini } & 473 & 1,238 & 7,024 & 9,768 & 13 & 18,516\end{array}$

Reg. 2 Pomeroon/ Supenaam $21,153 \quad 6,546 \quad 8,932 \quad 5,200 \quad 135 \quad 41,966$

Reg. 3 Essequibo/

$\begin{array}{lllllll}\text { W. Dem. } & 77,963 & 15,544 & 8,720 & 195 & 338 & 102,760\end{array}$

Reg. 4 Demerara/

Mahaica $123,803 \quad 133,058 \quad 49,868 \quad 1,308 \quad 2,721 \quad 310,758$

Reg. 5 Mahaica/ $\begin{array}{lllllll}\text { Berbice } & 39,349 & 13,666 & 2,413 & 72 & 56 & 55,556\end{array}$

Reg. 6 E.Berbice/ $\begin{array}{llllll}\text { C'tyne } 106,105 & 28,949 & 10,755 & 2,966 & 192 & 148,967\end{array}$

Reg. 7 Cuyuni/ Mazaruni $\quad 4,770 \quad 4,188 \quad 6,253 \quad 2,704 \quad 26 \quad 17,941$

Reg. 8 Potaro/ $\begin{array}{llllll}\text { Siparuni } & 78 & 619 & 946 \quad 4,029 & - & 5,672\end{array}$

Reg. 9 Upp. Takutu/ $\begin{array}{lllllll}\text { Upp. Ess. } & 189 & 598 & 1,756 & 12,739 & 56 & 15,338\end{array}$

Reg. 10 Upp. Dem/ $\begin{array}{lllllll}\text { Berbice } & 1,624 & 25,438 & 9,800 & 1,638 & 98 & 38,598\end{array}$

Total $\quad 375,507229,844 \quad 106,46740,6193,635756,072$

Source: Statistical Bureau 1987. 


\section{INFRASTRUCTURE AND URBAN DEVELOPMENT}

Three national development plans (1966-1972, 19721976, and 1978-1981) have been formulated during the period under review. This section examines each of the three plans and elaborates on their goals, objectives, and accomplishments as they relate to the provision of infrastructure in urban and rural areas. Since there were no national development plans after 1981, infrastructural provision beyond this point is assessed through budgetary sectoral allocations and regional allocations of expenditure. To provide a greater understanding of urbanrural differentials, this section also attempts to compare access to services between the urban and rural sectors. Economic difficulties have constrained urban development. Thus, the 1982 Georgetown Planning Area Development Plan stands out in the context of little if any urban planning efforts. An assessment of the plan is made, and the problems confronting the capital city are outlined. Guyana's first development plan after independence was prepared by a team of foreign experts from Britain, Canada, and the United states. Headed by Sir Arthur Lewis, the team prepared a seven-year development program for the 1966-1972 period, which proposed 25 major goals/objectives (Appendix 
A) ${ }^{24}$

The development program envisaged a total expenditure of $\$ 294.25$ million over the seven-year period (Table XLVI). The proposed capital expenditure of the plan was considerably more than those of the previous development plans. As Table XLVI reveals, heavy emphasis was placed on the development of the country's physical and social infrastructure. A large proportion of the plan's expenditure outlay was concentrated on transportation (especially roads), sea defenses, drainage and irrigation, electric power, telecommunications, housing, health, sanitation, and water supply. I $\dot{\tau}$ was believed that attention on developing Guyana's infrastructure would entice substantial inflows of foreign investment, on which successful implementation of the plan depended. This investment would in turn stimulate GDP, reduce unemployment, and raise the real income and welfare of the population.

The pattern of expenditure of the 1966-1972 development plan was much different from those prepared in the Jagan era. In the 1966-1972 plan, only 24.9 percent of the development expenditure was allocated to agriculture (including sea defenses, drainage and irrigation, and fishing), compared with 46.7 percent in the 1960-1964

${ }^{24}$ Government of Guyana. 1966. Development Programme 19661972. Georgetown: Government Printery; Barker, A. 1968. Development Planning and Plan Implementation in Guyana. Georgetown, pp. 12-14. 
TABLE XLVI

ALLOCATION OF DEVELOPMENT EXPENDITURE

1966-1972 DEVELOPMENT PLAN

(G\$ MILLIONS)

\begin{tabular}{|c|c|c|c|}
\hline & & Expenditure & $\underline{\text { 首 }}$ \\
\hline 1. & $\begin{array}{l}\text { Agriculture } \\
\text { Drainage and irrigation } \\
\text { Sea defenses } \\
\text { Fishing } \\
\text { Land development }\end{array}$ & $\begin{array}{l}73.11 \\
(40.11) \\
(14.00) \\
(0.60) \\
(3.18)\end{array}$ & 24.9 \\
\hline 2 . & Forestry & 6.28 & 2.1 \\
\hline 3 . & Industry and Trade & 16.90 & 5.7 \\
\hline 4 . & Electric power & 15.00 & 5.1 \\
\hline 5 . & $\begin{array}{l}\text { Transportation } \\
\text { Roads }\end{array}$ & 65.08 & 22.1 \\
\hline & $\begin{array}{l}\text { Roaas } \\
\text { Railways }\end{array}$ & $\begin{array}{l}(37.80) \\
(1.95)\end{array}$ & \\
\hline & Airports & $(5.10)$ & \\
\hline & Berbice Channel & $(8.20)$ & \\
\hline 6 . & Telecommunications & 9.22 & 3.1 \\
\hline 7 . & Resettlement schemes & 4.00 & 1.4 \\
\hline 8 . & Education and training & 12.24 & 4.2 \\
\hline 9 . & $\begin{array}{l}\text { Housing, urban, and rural } \\
\text { community development }\end{array}$ & 5.34 & 8.6 \\
\hline $\begin{array}{ll}10 . \\
11 .\end{array}$ & $\begin{array}{l}\text { Health, sanitation, water supply } \\
\text { Public safety and national def. }\end{array}$ & $\begin{array}{l}19.48 \\
17.76\end{array}$ & $\begin{array}{l}6.6 \\
6.0\end{array}$ \\
\hline & $\begin{array}{l}\text { vehicles } \\
\text { verich }\end{array}$ & 13.24 & 4.5 \\
\hline 13 . & Resource surveys & 4.30 & 1.5 \\
\hline & Miscellaneous & 12.30 & 4.2 \\
\hline & Total & 294.25 & 100.0 \\
\hline
\end{tabular}

Source: Development Programme 1966-1972.

development plan; industry and trade increased from 3 percent to 5.7 percent; housing from 3.6 percent to 8 percent; and transportation and communications from 11.2 percent to 25.2 percent. Whilst the plan did not give a clear breakdown of expenditures between the urban and rural sectors, the movement away from agriculture represented a 
fundamental shift from the rural Indian farmer to the urban African wage earner. ${ }^{25}$

Although the 1966-1972 plan encouraged the notion of self-reliance, the dependence on international funding rendered this objective a virtual impossibility. Foreign investment, however, proved to be elusive, and considerable difficulty was encountered in achieving anything close to the required levels of financing. Besides the lack of funding, the plan faced a number of additional difficulties. The objectives were not clearly stated. There was no overall integration of the various sectors and projects. Each project was a separate entity, having little or no relationship to other projects that were being implemented. Problems were encountered in recruiting personnel with the requisite skills and in retaining them. And, above all, the targets that were set by the planners were far too ambitious and could not conceivably be met within the allotted time frames. Consequently, in 1970, the government abandoned its first plan of the post-independence era.

When the achievements of the government in infrastructural development during the 1966-1970 plan period are reviewed, very few successes are readily apparent.

${ }^{25}$ Standing, G. 1979. Socialism and Basic Needs in Guyana. In G. Standing and R. Szal, Poverty and Basic Needs: Evidence from Guyana and the Philippines. Geneva: ILO, World Development Programme, p. 26; Greene, J. 1976. "The Politics of Economic Planning in Guyana." Social and Economic Studies 23 (2), p. 198. 
However, it was evident that improvements were being directed to districts from where the government drew its largest support. During the plan period, $196 \mathrm{miles}$ of road were either constructed or completely rehabilitated and another 63 miles improved. However, the only completely new road constructed during the period was the highway connecting Georgetown to the bauxite-mining town of Linden. A comprehensive potable water supply program was developed and designed to mobilize capital investments through a phased program with priority areas defined. Similarly, the first phase of the project covered the population from Buxton to Soesdyke, another area of party support. ${ }^{26}$ Political patronage was particularly evident in the government's housing program. Virtually all of the housing schemes which were initiated were located in Linden, Georgetown, and New Amsterdam.

In 1970, 92 percent of Georgetown's and New Amsterdam's populations were served by a house-connected water supply, compared with 32 percent of the rural population. ${ }^{27}$ In the following year, a National Food and Nutrition survey found that one in eight rural households did not even have piped

${ }^{26}$ Hoyte, D. 1973. The Great Advance in Infrastructure Development Under the P.N.C. Government. Address by Desmond Hoyte Minister of Works and Communications at the 16 th Annual Delegates Congress of the PNC, May 2-10, 1973. Georgetown, p. 12.

${ }^{27}$ UNDP. 1972. Background Paper. Country Programming 19721976. Georgetown: Cooperative Republic of Guyana, p. 77. 
water within 100 yards of their dwellings. ${ }^{28}$ All households in the urban centers were supplied by piped water within the 100-yard boundary. The availability of running water enabled 90 percent of urban households to have access to a flush toilet (shared with another household in 30 percent of the cases). The lack of running water in the rural areas meant that almost 90 percent of rural households resorted to pit latrines (shared by 22 percent of all householders).$^{29}$ similarly, over 95 percent of urban households had a bathroom/shower, while only 85 percent of rural households possessed this basic facility.

In 1971, the population per physician was 4,695; per dentist, 25,000; per nurse and midwife, 917; and per nursing auxiliary, $18,868 . .^{30}$ In addition, the low personnel/population ratio was inequitably distributed, with concentration in the urban areas. ${ }^{31}$

Urban populations were also better educated than their rural counterparts. According to the 1970 census, the rural population was found to be lagging on all educational scales. In Georgetown, 23 percent of males leaving school were in possession of high school diplomas of some kind. In

${ }^{28}$ PAHO. 1976. The National Food and Nutrition Survey of Guyana. Washington, D.C., p. 73 .

${ }^{29}$ Ibid.

${ }^{30}$ UNDP 1972, op. cit., p. 79.

${ }^{31}$ Ibid. 
New Amsterdam the rate was 18 percent, while in the rural areas it was 5 percent. In the realm of higher education, the University of Guyana was firmly established in 1969 on a 140-acre campus at Turkeyen, on the outskirts of Georgetown. Included in the 1966-1972 national development plan were several town planning schemes, which further highlighted the government's proclivity to reward certain sections of the population. The politics of planning resulted in a Regional Planning scheme for the development of Linden; an Improvement Scheme for the Georgetown suburb of Lodge, for the provision of better drainage and roads; and an Improvement Scheme for La Penitence, for the orderly development of the area and rehabilitation of its buildings. The 1966-1972 development plan was abandoned on February 23, 1970, when Guyana became the first Cooperative Republic in the world. In this new philosophic arrangement, it was envisioned that cooperatives would become the third sector of the economy (in addition to public and private enterprise), and the main vehicle for achieving an egalitarian society based on social and economic justice. The cooperative would allow the "small man" meaningful identification with all aspects of control and decision making in Guyana. It would be the vehicle for social and economic change which would redress the country's underdevelopment, curb rural-urban migration, diversify the economy, and promote a more equitable distribution of the 
country's population.

In line with the above stated goals, the government began to formulate a new, more comprehensive national development plan. Initially the government attempted to prepare a 10-year plan for the 1971-1980 period, which would be undertaken primarily by Guyanese planners. However, the project was scaled down, and a draft of a five-year plan for 1972-1976 was released in 1973 .

The 1972-1976 Development Plan's expressed development objectives were the creation of employment opportunities for all Guyanese, the attainment of an equitable distribution of income, the achievement of an equitable geographical distribution of economic activities, and the establishment of a foundation for the attainment of self-sustained economic growth. ${ }^{32}$ However, the short-term strategy of the plan was to "feed, clothe, and house the Nation by 1976."33 In attempting to achieve the above-stated objectives, the 1972-1976 plan acknowledged agriculture's pivotal role in the development strategy. The attention to agriculture initially appeared to be in stark contrast to the urban bias of the previous plan. However, the allocation of development expenditure tells another story. In the 19661972 plan, 24.9 percent of the total planned expenditure was

${ }^{32}$ Government of Guyana. 1973. Draft Second Development Plan 1972-1976. Georgetown: Ministry of Economic Development, p. 81 .

${ }^{33}$ Ibid., p. 72 . 
devoted to agriculture; but in the 1972-1976 plan, agriculture's share fell to 16.7 percent (Table XIVII).

TABLE XLVII

ALLOCATION OF DEVELOPMENT EXPENDITURE

1972-1976 DEVELOPMENT PLAN

(G\$ MILLIONS)

\section{Sector}

1. Agriculture Fishing

2. Forestry

3. Mining and quarrying

4. Manufacturing Power

5. Engineering and constrn.

6. Distribution

7. Transport and communication

8. Housing

9. Buildings and equipment

10. Other investment

Total
Expenditure

192.0

(27.0)

64.5

62.0

187.0

$(82.0)$

10.0

37.0

207.9

250.0

136.0

5.0 $\stackrel{\%}{\underline{0}}$

16.7

5.6

5.4

16.2

0.9

3.2

18.1

21.7

11.8

0.4

$1,151.4$

100.0

Source: Draft Development Plan 1972-1976.

The program to feed the nation would be accomplished

by replacing imports through the expansion of local

production. By expanding domestic production, the

government hoped that the immediate direct benefits would

include incorporation of idle arable and pasture lands, reduction of the dependence of the agricultural sector on rice and sugar, establishment of agro-based industries, and creation of additional employment opportunities. The planners, however, realized that they would have to remove a number of constraints in order to successfully implement the program. Accordingly, the plan suggested that the 
inadequate drainage and irrigation facilities be improved through installation of additional pumps, digging of canals, and construction of kokers, ${ }^{34}$ sluices, and dams. And it suggested that the poor transportation network be augmented by the construction of roads and by improvement of air and water transport to facilitate the movement of inputs and outputs.

To clothe the nation, the government proposed the establishment of a textile mill in Georgetown to produce cloth. Initially it was expected that yarns would have to be imported, but in time this importation would increasingly be replaced by local cotton production. In addition, the plan called for the creation of a leather factory to convert hides into the subsequent manufacture of shoes, hats, handbags, and other types of leather goods.

To house the nation, the guvernment earmarked 21.7 percent, or the lion's share, of total development expenditure of the 1972-1976. plan period (Table XLVII). It was estimated that there was a shortfall of 30,000 housing units in the country in $1970 .{ }^{35}$ To rectify the shortage, and to be able to adequately house the growing population, the plan called for the construction of 65,000 housing units by 1976 , of which 31,000 units would be built by the public and cooperative sectors and 34,000 units by the private

\footnotetext{
${ }^{34}$ Flood-gates.

${ }^{35}$ UNDP 1972, op. cit., p. 88 .
} 
sector. ${ }^{36}$ To assist the housing program, the plan urged the production of building materials which would utilize domestic raw materials whenever possible. These building materials included the production of steel rods, cement, stone, clay blocks, lumber, nails, pipes, tiles, bolts, screws, windows, sinks, cables, paints, and so on. Centering its attention on Georgetown and New Amsterdam, the plan outlined the investment activities which would be undertaken during the 1972-1976 period. These included:

In Georgetown -

1. establishment of factories in and around Georgetown, for example, automobile components, building materials manufacture, and extension of present manufacturing activities;

2. reconstruction of the road approaches to Georgetown and the main arterial roads within greater Georgetown;

3. improvement of the drainage system to cope with the expansion of the city;

4. improvement and expansion of water supply, sewage, and other waste-disposal systems;

5. completion of the construction of new sea defence works;

6. Continued redevelopment of the business and commercial center of the city;

7. redevelopment of the Georgetown hospital;

8. completion of the cultural center;

9. upgrading of Ogle Airport;

10. continuation of the program of house construction;

11. continued development of the University of Guyana complex.

In New Amsterdam -

1. rehabilitation and improvement of the fish storage facilities;

2. establishment of light manufacturing factories for

${ }^{36}$ Draft Second Development Plan 1972-1976, p. 314 . 
the assembly of refrigerators and electrical appliances.

By 1976, it was evident that the government's expectation to feed, clothe, and house the nation had not been met. The failure to achieve the stated objectives of the plan "in any satisfactory way" was noted by Prime Minister Burnham in his message to the P.N.C. on December $14,1976 . .^{38}$ The program to build 65,000 units by 1976 was an abject failure. Even those who were sympathetic to the government could only claim that during the period, houses were being built at an annual rate of 3,000 by all sectors of the economy - a figure that was well below the target of 13,000 per annum. ${ }^{39}$ Some trade unionists have even suggested that only 6,000 housing units were built during the entire period. ${ }^{40}$ Failure to achieve the target was attributed by the government to bottlenecks such as lack of building materials and skilled manpower. ${ }^{41}$ what little housing was provided accrued to areas of party support. Built houses meant that many of the lower-income groups in the urban centers and villages along the coast continued to live in shelters with the minimum requirements, while the

${ }^{37}$ Ibid., pp. 137-138.

${ }^{38}$ Burnham, F. 1976. Address to the PNC. Georgetown, p. 26.

${ }^{39}$ Dick, C. 1984. Housing the Nation over two Decades. Unpublished, p. 27.

${ }^{40} \mathrm{Jeffrey}$ and Baber 1986, op. cit., p. 139.

${ }^{41}$ Standing 1979, op. cit., p. 52 . 
government completely ignored the problems of housing in the hinterland and interior regions.

Despite the failure of the housing program, a number of infrastructural works were undertaken, which gave the countryside some of the services and amenities which were already available in the urban areas and Georgetown in particular. In the area of education, the historical dependence for high school education on Georgetown was lessened by the building of six multilateral schools (these schools were expected to provide a five-year diversified course covering academic, technical, agricultural, and commercial education) at Mahaica, Bladen Hali, Anna Regina, Ruimveldt, Iinden, and New Amsterdam. Two higher-education institutions, Kuru-Kuru Cooperative College and the Guyana School of Agriculture, were also opened outside of Georgetown.

Ironically, the planned provision of more schools in the rural areas was used as an excuse by the government to phase out its railway operations. In 1970, the government closed 49 miles of track from Mahaica to Rosignol, and in 1972 the last 12 miles of the East Coast Railway between Georgetown and Mahaica were scrapped. The smaller West Coast Railway from Vreed-en-hoop to Parika ceased operation in $1974 .{ }^{42}$ The East Coast Railway had been used by large

\footnotetext{
${ }^{42}$ Government of Guyana. 1980. 50 Years of service.
} Transport and Harbours Department, p. 23 . 
numbers of school children from the rural areas to attend school in the capital, and it was felt that abandonment of this railway would have increased congestion on the main coastal road. The surfacing of the main road on the Atlantic coast, from Charity on the Pomeroon River to Crabwood Creek on the Corentyne River, also provided the railway with stiff competition and precipitated its demise. The completion of the Coastal Highway was met with lukewarm support by those in Corentyne. Corentyne residents were upset to find a series of tollgates dotted along their section of the highway. For many, these were perceived as just another in a long series of government measures which were unfairly aimed at the Indian farmer; this segment of the population was adversely and disproportionately affected, since other more-travelled sections of the highway in predominantly African-populated areas, including the Soesdyke/Linden Highway, were devoid of tollgates.

The situation with regard to electrical power was somewhat mixed. A rural electrification program began with the extension of services on East Coast and East Bank Demerara from Mahaica Creek to Timheri and on West coast and West Bank Demerara from De Kinderen to Plantation Vriesland. At the end of 1976, the Guyana Electricity Corporation (GEC) was engaged in improving and extending services on the Essequibo coast and Islands, West Coast Berbice and the Corentyne Coast, and Bartica. Many isolated areas and some 
intermediate settlements, however, remained outside the program and without supply.

The Guyana Water Authority (GUYWA) was established on October 1, 1972, to control and regulate the collection, production, storage, transmission, distribution, and use of water. ${ }^{43}$ In addition, GUYWA was expected to ensure that standards in the rural areas would be comparable to those in the urban centers. According to the 1972-1976 plan, services were expected to cover Georgetown, New Amsterdam, Linden, East Bank and East Coast Demerara, West Coast and East Bank Berbice, the Corentyne Coast, and selected areas in the interior. ${ }^{44}$ The new authority was extremely slow in acting on its mandate, and by 1976, other than the urban centers of Georgetown, New Amsterdam, and Linden, only East Bank and East Coast Demerara were approaching completion of a potable water supply system.

Having failed to achieve many of the objectives of the 1972-1976 plan, the government decided that the plan should be "rolled over" into 1977. In the 1978 budget, the government set forth its final plan of the post-independence era. The plan outlined a four-year development program for 1978-1981, with a continued emphasis on project development. Implementation of the plan would be carried out by a newly 365.

${ }^{43}$ Act No. 3 of 1972 .

${ }^{44}$ Draft Second Development Plan 1972-1976, op. cit., p. 
formed state Planning Commission. A look at the program's planned allocation of development expenditure indicated that the government had markedly increased its investment in agriculture whilst at times lowering those of education, health, housing, and roads (Table XLVIII). The plan was primarily concerned with the tripartite productive sectors of sugar, bauxite, and rice, whose continued development it was argued, would achieve the goals and objectives of the previous plan and bring about a socialist society.

TABLE XLVIII

\section{ALLOCATION OF DEVELOPMENT EXPENDITURE} 1978-1981 DEVELOPMENT PLAN

Sector

1. Agriculture

2. Forestry and fishing

3. Mining and quarrying

4. Manufacturing

5. Power

6. Education and social development

7. Health and housing, roads

8. Sea defense

8. Sea defense $r \begin{array}{r}1.9 \\ \text { 9. General administrative \& other services } 19.9\end{array}$ Total

Total Investment $\stackrel{\circ}{\circ}$

33.5

7.8

12.9

3.9

6.5

3.9

6.8

19.9

97.1
$\$ G 1,282,000$

Source: Adapted from Potter 1987, p. 237.

Between 1978 and 1981, capital expenditures increased rapidly, from 117.3 million dollars to 423 million dollars. In keeping with the 1978-1981 Development Plan, the largest component of government capital expenditure was on agriculture, although the sector's share was a little lower 
than had been planned (Table XLIX). The focus on agriculture suggested that there was a spatial shift in government policy from urban to rural areas. This belief was further strengthened by the fact that outlay on roads and infrastructure, contrary to the recommendations of the 1978-1981 Development Plan, was the second-largest component of government capital expenditure, with much of the allocation monies being centered on previously neglected areas such as East Coast Berbice and Upper Essequibo. Whilst sectoral spending appears to have favored rural areas, the 1979 budget presented quite a different story. This was the first budget in which capital expenditure was allocated on a regional basis (Figure 5), and it provided clear evidence that Georgetown, Linden, and the urban areas in general were the prime beneficiaries of the public purse (Table L). Almost 58 percent of capital spending was devoted to Region 3 (Central Demerara and West Berbice) and its two urban centers of Georgetown and Linden. The skewed distribution of capital expenditure was particularly disastrous for Regions 1, 5, and 6. The concentration of expenditure on the coast meant that these three regions, which represented the interior areas of the country, received only 6.1 percent of the total capital expenditure. According to potter, capital spending on a per-capita basis in 1979 was even more instructive, for it revealed that the hinterland regions were quite well positioned, and 
TABLE XLIX

CENTRAL GOVERNMENT CAPITAL EXPENDITURE BY SECTORS 1978-1981 (G\$ MILLIONS)

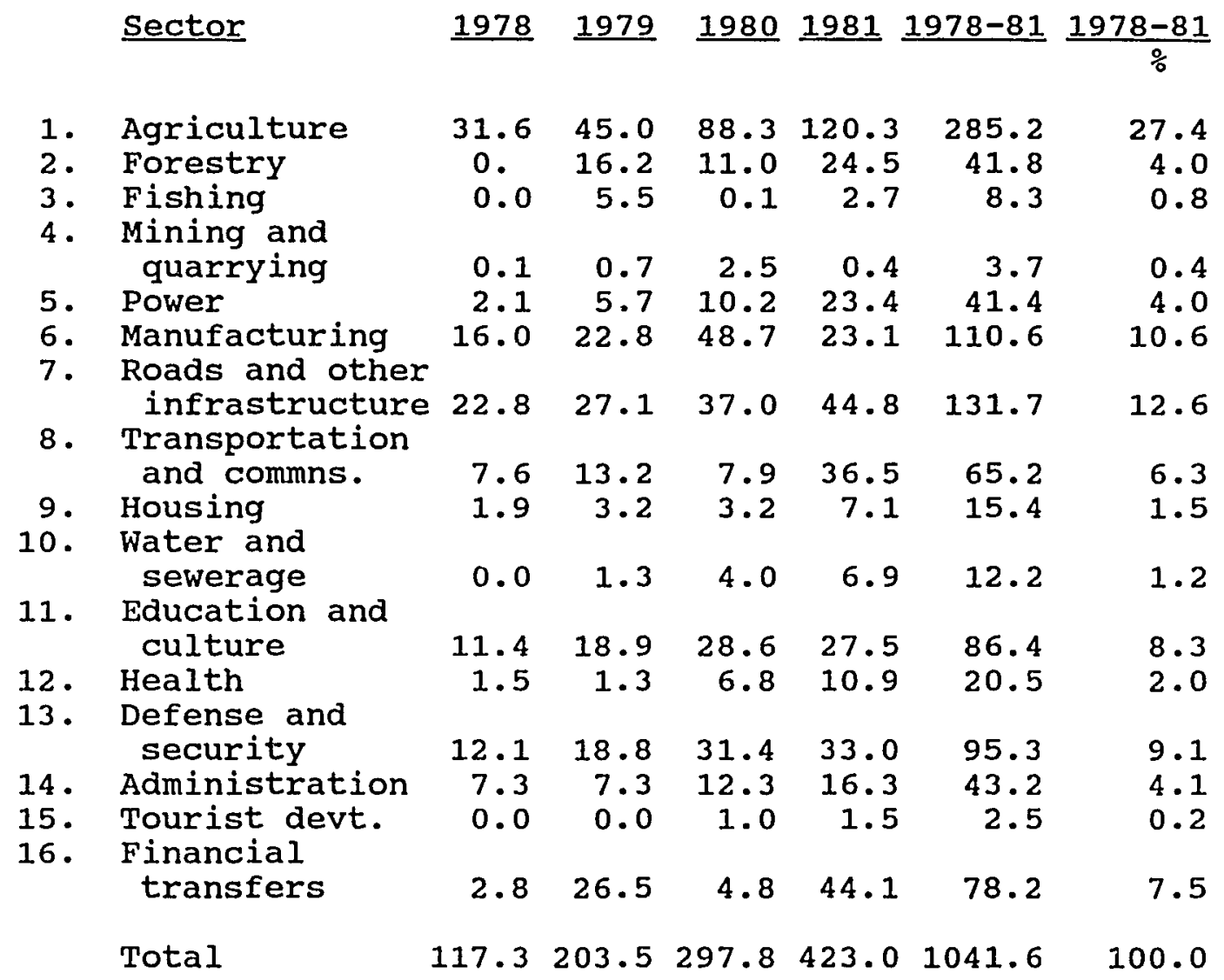

Source: Estimates 1981.

"it was in fact the 'peripheral' coastal areas (Regions 2 and 4), the heartland of the Indo-Guyanese population, which were not receiving their fair share."45

Between 1982 and 1990, Guyana's economic difficlities

${ }^{45}$ Potter, L. 1987. Guyana: Cooperative Socialism, Planning and Reality. In D. Forbes and N. Thrift (eds.). The Socialist Third World. Urban Development and Territorial Planning. New York: Basil Blackwell, p. 238. 
TABLE L

REGIONAL ALLOCATION OF CAPITAL EXPENDITURE 1979 (PERCENTAGE)

\section{Region}

Reg. 1 North-West

Reg. 2 Essequibo \& West Dem.

Reg. 3 East Dem. \& West Berbice

Reg. 4 East Berbice

Reg. 5 Mazaruni/Potaro

Reg. 6 Rupununi

Georgetown

Linden

New Amsterdam

Total

Source: Adapted from Potter, 1987, p. 238. of Allocation

$$
\begin{array}{r}
2.1 \\
13.0 \\
24.3 \\
9.6 \\
3.0 \\
1.0
\end{array}
$$

28.0

4.8

13.5

100.0

resulted in nearly 40 percent of central government capital expenditure being tied up in financial transfers (Table LI). The growth in financial transfer allocations meant that most sectors of the economy witnessed some reductions in their budget allocations. Agriculture was the second-largest recipient of government spending, but its share was now only 19.5 percent. Roads and other infrastructure was the third most important sector, with 12.2 percent of capital expenditure, but it was the only other sector which received more than 10 percent of central government spending. With so much of the capital expenditure budget tied to financial transfers, the urban and rural areas in some ways were equally neglected. The international constraints on the domestic economy seriously impeded the government's ability 


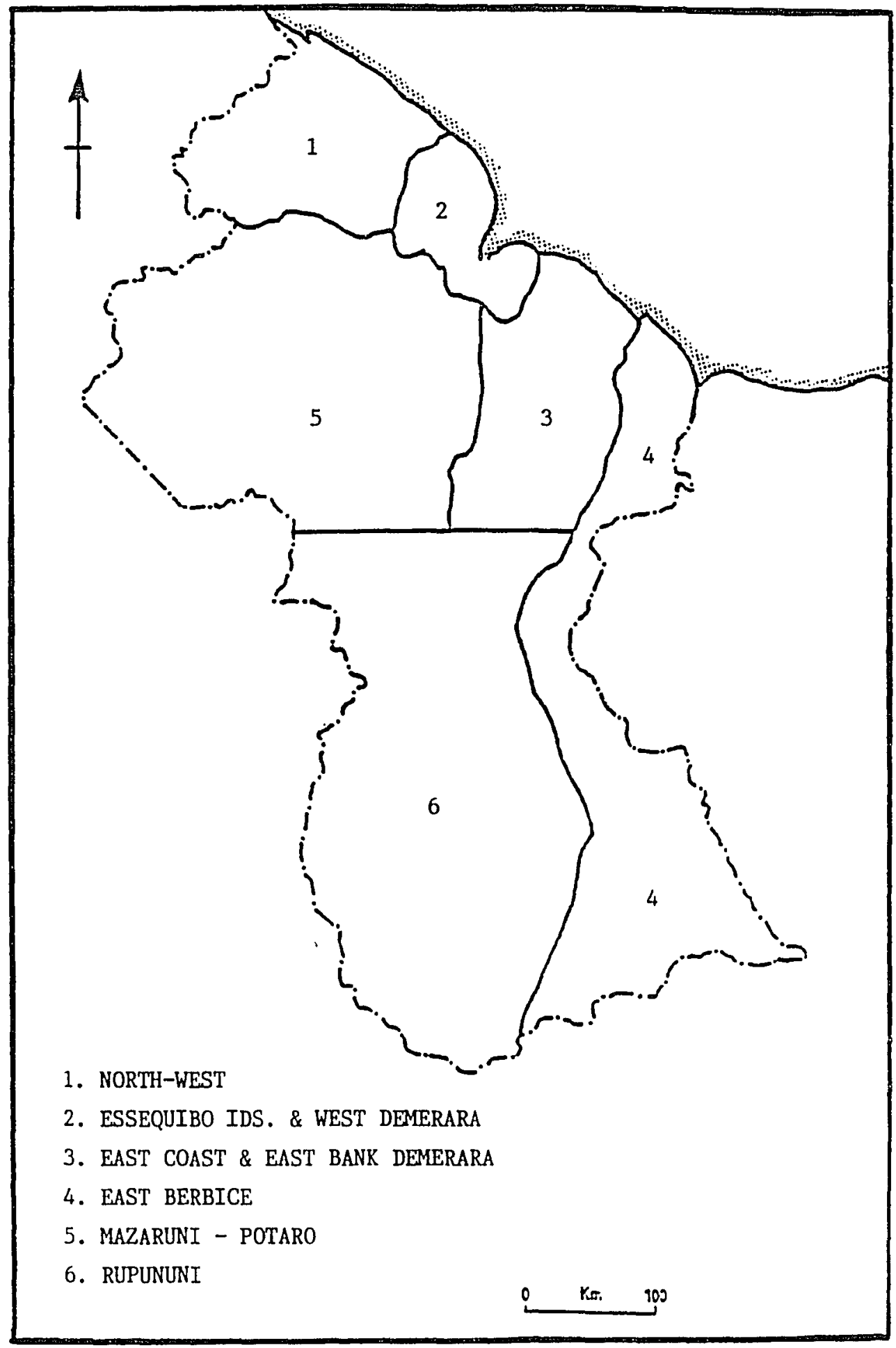

Figure 5. Administrative Regions 1973 
to finance development planning in the country, and its attempts to reduce spatial inequalities.

\section{TABLE LI}

CENTRAL GOVERNMENT CAPITAL EXPENDITURE BY SECTORS 1982-1990

Sector

1. Agriculture

2. Forestry

3. Fishing

4. Mining and quarrying

5. Power

6. Manufacturing

7. Roads and other infra.

8. Trans. and commns.

9. Housing

10. Water and sewage

11. Education and culture

12. Health

13. Defense and security

14. Administration

15. Tourist development

16. Financial transfers

Total
$1982-1990$

(G\$ Mn)

$1,698.1$

41.4

155.6

262.5

55.8

40.1

$1,063.6$

383.2

31.9

148.1

507.9

154.0

306.1

402.3

1.7

$3,435.4$

$8,687.7$
1982-1990

(\%)

19.5

0.5

1.8

3.0

0.6

0.5

12.2

4.4

0.4

1.7

5.8

1.8

3.5

4.6

0.0

39.5

$99.8^{1}$

Source: Estimates 1982-1990.

1. Rounding accounts for deviations from 100 percent.

In 1980 a new regional administrative system was enacted. The country was divided into ten administrative regions, and the five urban areas of Georgetown, Linden, New Amsterdam, and Rose Hall were granted separate powers to manage their own affairs. Municipal subventions were provided by the central government, but the figures for these have not been made available to the public. For the 1982-1990, period however, regional allocations of capital 
expenditure continued to favor the coastal regions, and in particular Regions 2, 3, 4, 5 and 6 (Table LII). Regions 2 and 3 , predominantly populated by Indians, were the two most important recipients of government capital expenditure. This apparent reversal of policy must, however, be placed in perspective, since the Tapakuma Irrigation Project in Region 2, and the Demerara Forestry Development Project in Region 3 , accounted for the bulk of the expenditures in these two regions. By contrast, the heartland of the Indian population, Region 6, was among the lowest recipients of government spending on a per-capita basis.

TABLE LII

\begin{tabular}{|c|c|c|c|}
\hline & Region & $\frac{1982-1990}{(\mathrm{GS} \mathrm{Mn})}$ & $\frac{1982-1990}{\left(\frac{9}{6}\right)}$ \\
\hline Reg. 1 & Barima/Waini & 14.44 & 3.3 \\
\hline Reg. 2 & Pomeroon/Supernaam & 65.41 & 15.1 \\
\hline Reg. 3 & Essequibo/W. Dem. & 165.52 & 38.2 \\
\hline Reg. 4 & Demerara/Mahaica & 44.03 & 10.1 \\
\hline Reg. 5 & Mahaica/Berbice & 45.81 & 10.6 \\
\hline Reg. 6 & E. Berbice/c'tyne & 42.66 & 9.8 \\
\hline Reg. 7 & Cuyuni/Mazaruni & 17.21 & 4.0 \\
\hline Reg. 8 & Potaro/Siparuni & 7.09 & 1.6 \\
\hline Reg. 9 & Upp. Takutu/Upp. E'bo. & 10.45 & 2.4 \\
\hline Reg. 10 & Upp. Dem./Berbice & 21.23 & 4.9 \\
\hline & Total & 433.85 & 100.0 \\
\hline
\end{tabular}

Source: Estimates 1982-1990.

For most of the 1966-1981 period, the central Housing and Planning Authority (CHPA), the authority in charge of urban planning, was relatively inactive as a result of the 
government's concentration on national/regional planning as a means of improving the living conditions of the population through economic growth. During this time the CHPA was primarily functioning as a support organization in national economic development programs - for example, by providing expertise in land settlement schemes, housing, and industrial location. In late 1980, however, the CHPA was asked to prepare a new physical plan for the Georgetown area. Up to this time, guidelines for the development of Georgetown -- with regard to its commercial, industrial, and residential areas -- were under the auspices of the 1950 Greater Georgetown Plan. And whilst, the 1950 plan was a commendable one, by 1980 it no longer reflected the realities of conditions in the capital. In 1970, the demands for additional housing in areas such as North Ruimveldt, South Ruimveldt Park, and Festival City (planned and built for Carifesta in 1972), and also for such unanticipated uses as the University of Guyana, had to be met by encroachment on the greenbelt zone of that plan. Increasingly the greenbelt became the home of a number of government buildings, which were erected without the benefit of an integrated comprehensive plan. The 1950 plan's allocation for housing, commercial, and industrial uses had become virtually obsolete, and all three sectors were facing shortages of developable land in Georgetown. The horizontal unplanned spread of the capital city was beginning to pose 
serious environmental concerns. Development had reached a stage where productive agricultural land was being

threatened. Furthermore, the increase in population

combined with haphazard development resulted in enormous pressures on the city's infrastructural facilities such as electricity and water supply, transportation, sewage, health, education, and so on.

Cognizant of the above deficiencies, the CHPA in 1980 began to formulate a new Georgetown Plan with the following objectives in mind:

1. To identify problems, constraints, and prospects for future physical development and for proper land-use planning of the area.

2. To formulate a long-term physical development strategy and an integrated broad development plan to the year 2000, thereby providing a basis for promoting, guiding, and controlling physical development within the Georgetown Planning Area in the immediate and short term.

3. To indicate a specific action programme for the next five years to remedy the critical problems facing the Planning Area at the moment. ${ }^{6}$

In 1982, a new plan for Georgetown was introduced. However, little confidence was placed in the document. Those who were responsible for the plan at the outset alluded to the difficulties encountered in its formulation. Firstly, there was a lack of cooperation from other governmental agencies. Over 30 governmental agencies were consulted by the CHPA, and many failed to provide data and

${ }^{46} \mathrm{CHPA}$. 1982. Georgetown Planning Area Development Plan Vol. 1, Summary Report, p. 2 . 
other material inputs. Secondly, there was a general lack of data. Data on population, labor force, employment, and so on had to be estimated, since the government refused to divulge information from the 1980 census. In addition, no detailed information was available on land and property values, public utilities, and services. Thirdly, the planning authorities suffered from a shortage of personnel, even though the CHPA was assisted by staff from the United Nations. Fourthly, more time was needed to render a more satisfactory document. ${ }^{47}$

The plan outlined a list of 14 goals and objectives which were to be achieved in the Georgetown Planning Area (GPA) by the year 2000 or earlier (Appendix B). As of this date, none of the plan's goals and objectives have been met. This is partly a result of the plan's shaky informational and statistical foundations, but the major reason has undoubtedly been the poor performance of the economy. With the economy in tatters, urban planning and physical planning in general have become an afterthought. Verbally committed to socialism, the government nevertheless, has pursued planning policies and practices within an essentially capitalist social formation and under the dominance of the capitalist mode of production. Therefore, it is not surprising that efforts to ameliorate local and regional differentials is subjugated to, and controlled by, the

$$
{ }^{47} \text { Ibid. , p. } 13
$$


forces of capitalist accumulation.

Georgetown does not contain enough directly productive activities to maintain its physical and social infrastructure, it must rely on appropriations from the state, which in turn is dependent on the functioning of the national economy. The poor performance of sugar, bauxite, and rice in recent years, however, has led to a reduction of surplus concentration in the urban areas.

In December 1990, Georgetown's Mayor, Compton Young, acknowledged that there had been a breakdown in services between 1970 and 1990, and that the Georgetown city Council had been unable to attract enough staff and money to better maintain the city. ${ }^{48}$ Lack of maintenance is evidenced in the rapid deterioration of the city roads. Massive potholes are a common occurrence on most of the major thoroughfares including Norton, Lamaha, and Middleton streets. According to the independent stabroek News:

The pot holes in some areas have graduated into craters. Certain roads are more pock-marked than the surface of the moon. A city ride is all swerve, shudder, and jar. ${ }^{49}$

The supply of potable water in the past was only an occasional problem in Georgetown. Now, in many areas of the city -Wortmanville, Newtown, Campbellville, South Ruimveldt, Lodge, Werk-en-Rust, Charlestown, Kitty, Bel Air, Prashad

\footnotetext{
${ }^{48}$ Stabroek News, December 4, 1990.

${ }^{49}$ Stabroek News, December 6, 1990.
} 
Nagar, Lamaha Gardens, and Lillendaal - water pressure is so low that householders are deprived of water for extended periods of time. Yard taps produce no water at all during the day, and residents have to wait until odd hours to collect a few buckets for next day's use. Water piped into the house is no longer available for most residents. The city's chief engineer estimated that the city was losing about 50 percent of its water supply through leaks in the distribution system. ${ }^{50}$ oftentimes when the water does flow, it is so discolored that using it for drinking or cooking purposes is unthinkable.

In comparison to a number of cities in the developing world, housing, or the lack thereof, is not a major problem in Georgetown. However, in recent years the quality of the housing stock has begun to decline, and very little new housing has been constructed since the completion of Roxanne Burnham Gardens. The government has abdicated its role of providing housing. The last two housing schemes to be constructed in Georgetown were the Shirley Field-Ridley Scheme on the Kitty Avenue and the ill-fated North East La Penitence Scheme in 1983. The North East La Penitence Scheme was expected to provide more than 120 houses for employees of the Health Ministry, the city Council, the Guyana National Newspapers Ltd., and a co-op group known as Excelsior; but by 1987, fewer than one-third of the houses 
had been completed, and tenants were without electricity, water, and sewage. ${ }^{51}$ The financially strapped government simply did not have the resources to provide materials for infrastructural development.

With the government no longer sponsoring housing schemes in Georgetown, it has increasingly looked to the private sector to take up the slack. Contractors and businessmen, however, are wary of entering the housing market. Many recall the rental freezes in the early 1970 s and early 1980s. They are also apprehensive about supply bottlenecks, and as a result the only private development in the works is a housing scheme on the East Coast Demerara Road, some 10 miles outside Georgetown.

The lack of new housing has led to the growth of informal housing in the city; and while the problem is relatively small, it is another indication of the city's ailing health. In 1982, the Georgetown Planning Area study noted four main "squatting areas" in the capital, housing some 100 squatters.52 The largest of them, Yarrow Dam, north of Alexander Village, was mainly comprised of small huts built of $z$ inc and salvaged materials. The huts were dilapidated, but the authorities made some effort to regularize the development by providing it with services such as water and electricity. Another squatting area was

\footnotetext{
${ }^{51}$ Stabroek News, May 15, 1987.

${ }^{52}$ Georgetown Planning Area Study - Vol. 1, p. 89.
} 
located along the Cummings Canal in Cummingsburg and Albertown. The houses here were originally sheds constructed for gardeners and have been converted into regular dwellings. Smaller squatter settlements were also identified in the eastern part of Botanic Gardens along the Lamaha Canal, and in East and West Ruimveldt Front Road Reserve.

More recently a new squatter settlement has mushroomed at Sophia, in the northeast section of the city. Situated adjacent to Prashad Nagar, an upper-class residential area, the development has encountered opposition from the government, which in the past has displayed a degree of tolerance of informal housing. By December 1990, roughly 150 families had taken up residence in the area and had built a similar number of dwellings. ${ }^{33}$ with more building developments in the offing, the CHPA energetically sanctioned the removal of squatters in Sophia. The scrutiny levelled at the Sophia squatters spilled over to older squatter settlements. The CHPA announced that squatters along the Lamaha Canal posed a severe danger of polluting the canal, the major source of the city's water supply, and that "expeditious and effective action" was necessary to remove them. ${ }^{54}$ And in February 1991, the city demolished a number of squatter shacks along the Lillendaal Railway

\footnotetext{
${ }^{53}$ Stabroek News, December 6, 1990.

${ }^{54}$ Stabroek News, January 24, 1991.
} 
Embankment. As of March 1991, building activity at Sophia remained unchecked, and no additional squatter settlements had been destroyed, despite President Desmond Hoyte's assertion that squatters in suburban Georgetown had to move. 55

In addition to the problem of informal housing, roughly 18 percent of all houses in the Georgetown area were deemed to be substandard in $1982 .{ }^{56}$ In some of the poorer areas such as Albouystown, Bourda, Lacytown, Tiger Bay and Lodge, roughly 50 percent of the residential buildings were officially categorized as dilapidated slums. ${ }^{57}$ High concentrations of buildings in poor structural condition were also noted in Lacytown, Lodge, West La Penitence, and Alexander Village. ${ }^{58}$

The areas of poor housing in Georgetown's urban landscape stand in stark contrast to the high-income residential areas in the central northern wards and the eastern wards of the suburbs. class contradictions reflected by intra-urban inequality have been evident since the colonial era, but the polarization evidenced today appears to be far more striking. The upper classes protect

${ }^{55}$ Stabroek News, February 3, 1991.

${ }^{56}$ Georgetown Planning Area study - Vol. 1, p. 184.

${ }^{57}$ Ibid., pp. 86-87.

${ }^{58} \mathrm{CHPA} .1982$. Georgetown Planning Area Development Plan Vol. 2 , p. 304 . 
themselves from the masses, and are isolated from them, through the creation of semi-fortified buildings replete with bars, grills, security fences, surveillance equipment, watchdogs, and security personnel. With a premium on large open spaces, this type of residential living has recently begun to appear in the south of Georgetown, in areas such as Peter's Hall and Providence. Meanwhile, the less fortunate must make do with the squalor and congestion of the slums and squatter settlements.

An offshoot of the stagnant economy and the attendant implementation of the government's corrective measures have resulted in the rise of petty-commodity production in the capital city. Inequality between the upper class and the masses in Georgetown is as acute in terms of employment opportunities and income as it is in terms of housing. In 1982, approximately 16 percent of the total number of households in Georgetown were engaged in petty-commodity production, of which 53 percent had stable, and 47 percent had unstable, employment in the sector. ${ }^{59}$ The majority of petty-commodity producers are vendors, who account for 30 percent of total households in the informal sector. Other notable informal occupations are tailors/seamstresses (14 percent), carpenters ( 7 percent), mechanics ( 5 percent), and salespersons ( 4 percent). Together, these occupations account for 60 percent of all households engaged in informal

\footnotetext{
${ }^{59}$ Georgetown Planning Area Study - Vol. 1, p.36.
} 
activities. Although no up-to-date figures are available on the current size of the informal sector in Georgetown, it appears safe to conclude that its employment share has grown since 1982 , as persons in various skill categories continue to move into petty-commodity production as a means of selfemployment.

The problems so prevalent in Georgetown are also evident in the urban centers of New Amsterdam, Linden, Rose Hall, and Corriverton. For example, no planning scheme is in effect in New Amsterdam, and none is expected in the near future. Infrastructural facilities have deteriorated to the point where only the three major thoroughfares - the strand, Main street, and Republic Road - are paved and in tolerable condition. The road leading up to the New Amsterdam stelling was recently paved, but within days a pothole had re-emerged. The Town Council has been using waste from the upriver bauxite mining operations to repair the side streets. When there is no rainfall, dust from the side streets is strewn everywhere, and certain parts of the town with its red dusting takes on the appearance of the mining town of Linden. When the rains fall, the in-fill quickly washes away, exposing the town's all-too-familiar potholes. The in-fill also affects the free flow of the interlot drains, which are already fairly clogged by refuse due to the town's irregular collection of garbage. Electricity and water supplies are unstable. Power surges and fluctuations 
in the supply of current reduce the longevity of most electrical equipment. Residents are forced to buy surge protectors and other devices to protect their investments, but even these measures are often in vain. When water is available, the pressure is usually so low that only outlets at ground level are supplied. Some townspeople venture as far afield as the Guysuco sugar estate at Canje to fill up their plastic barrels - sent to them by relatives abroad with water. The once-majestic and ornate General Hospital has fallen into disrepair. Gaping holes are found in the hospital's roof, where zinc sheets have blown away and have not been replaced; and much of the structure, like the town, appears to be in imminent danger of collapse.

\section{Land Use}

Since independence, the central government has been playing an increasingly prominent role in attempting to transform the pattern of land use in Guyana. The following subsection of this chapter elaborates on the most recent attempts at creating land settlement schemes, and the role of regional planning in effecting new settlement patterns. Following independence in 1966, the government continued to maintain a number of land settlements on the coast, including, Cane Grove, Verdenoegen, Government Estates, Onverwagt, Anna Regina/Tapakuma, Charity, Amazon, and Black Bush Polder. However, in 1968, the government almost accidentally began to direct its attention to 
interior development and settlement, following the withdrawal of the African Manganese Company (an American concern) from the small interior mining town of Matthews Ridge. The town's 6,000 residents were wholly dependent on the company for their livelihood; and with closure of the mine, the government stepped in to assume the task of saving the town. Matthews Ridge was to be transformed into an agricultural settlement. Former mine workers were employed to clear land for themselves as well as new settlers, but progress was slow, and by 1971 little farming had taken place.

The expansion of land settlement in the interior nevertheless gained momentum with the initiation of the Soesdyke/Linden Land settlement Scheme alongside the recently completed 44-mile Soesdyke/Linden highway. Seven sites were identified as settlement centers in 1971 - KuruKururu, Yarowkabra, Low Wood, Long Creek, Dora, Clemwood, and Moblissa. ${ }^{60}$ Settlers were to be provided with 2,935 ten-acre agricultural lots and 3,517 one-acre residential lots. ${ }^{61}$ Initial reaction to the scheme was positive; and by March 1971, the authorities had received approximately 6,500 applications for leases from prospective migrants from Guyana and overseas. Since a large number of the overseas

${ }^{60}$ Downer, A. 1982. Settlement on the white Sands. In M. Thomas (ed). The Caribbean Peoples and their Environment. London: CHEC, p. 194.

${ }^{61}$ Ibid. 
group were of African origin from the West Indies, the granting of leases of highway lands was met with a certain degree of trepidation by other ethnic groups in the country. These groups felt that the central government was attempting to restore an African majority in order to consolidate its hold on power. In its defense, the government countered that it was merely attempting to develop and populate the interior for security considerations so as to stave off the territorial claims of neighboring countries.

As far back as 1969, Prime Minister Burnham had stated:

Increasingly we are turning our attention to the development of our interior. our existence upon the coastland is the result of a pattern imposed upon us by colonialism. our entry into the interior is an expression of our freedom. Already at Matthews Ridge and Kaituma we have laid the foundation for a development which in time will spread to include the whole of the North West. our motto now and in years to come must be: Forward! Go West, Go South, Go to the Land!

We cannot allow our rich hinterland to remain almost uninhabited and uncultivated. The sight of these rich lands lying unexploited tends to excite the avarice of some covetous souls and to encourage vaulting ambitions of others. We must possess these lands. To this end government is formulating plans for the orderly development of the interior. ${ }^{6}$

Guyana's Development Plan for 1972-1976 identified for the first time that regional planning would be employed as a strategy to achieve a more even geographical distribution of development, in order to reduce the pressure on social

\footnotetext{
${ }^{62}$ Burnham, F. 1970. A Destiny to Mould. London: Longman,
} pp. 150-151. 
facilities in the urban areas. ${ }^{63}$ The plan contended that the concentration of social amenities on the coast had made it difficult to fulfill the desired mobility of labor from the urbanized shelter of the coastlands to the potentially more rewarding hinterland. ${ }^{64}$ Furthermore, until that time, government efforts to develop and populate the areas away from the coast had been haphazard. Development was concentrated in a few selected areas. As of 1973, of the four large-scale land settlement schemes undertaken in the post-independence period, two (Soesdyke/Linden and Look out) were contiguous to the coastal belt (Table LIII).

The 1.972-1976 plan proposed that greater occupancy of the country's land would be accomplished by two distinct methods. The first method envisioned a gradual movement from the thickly populated coastlands to contiguous areas much like the intermediate savannahs along the Soesdyke/Linden Highway, as well as along the roads to Orealla, Rockstone, and Makouria. New settlements in these areas were expected to be within reach of existing ones to permit use of their infrastructural facilities such as water, sewerage, electricity, schools, health concerns, and so on. The second method involved a more direct movement to the interior, and required a production and transportation policy by which the needs of settlers would be met. In

\footnotetext{
${ }^{63}$ Draft Second Development Plan 1972-1976, p. 127.

${ }^{64}$ Ibid., p. 4 .
} 
TABLE LIII

LAND SETTLEMENT SCHEMES - 1973

\begin{tabular}{|c|c|c|}
\hline Location & Acreage & Agro-activity \\
\hline Wauna & 32,000 & $\begin{array}{l}\text { Peanuts } \\
\text { Citrus } \\
\text { oil palm }\end{array}$ \\
\hline Soesdyke/Linden & 64,000 & $\begin{array}{l}\text { Dairy farming } \\
\text { Citrus } \\
\text { Pineapple } \\
\text { Poultry }\end{array}$ \\
\hline $\begin{array}{c}\text { Matthews Ridge/ } \\
\text { Kaituma }\end{array}$ & 10,000 & $\begin{array}{l}\text { Cattle ranching } \\
\text { stock rearing } \\
\text { Citrus } \\
\text { Ground provision } \\
\text { Corn }\end{array}$ \\
\hline Look out & 300 & $\begin{array}{l}\text { Fruit } \\
\text { Vegetables } \\
\text { Livestock }\end{array}$ \\
\hline
\end{tabular}

Source: Guyana A Decade of Progress 1974, p. 47.

cases where interior settlements would be pursued away from mining and forestry complexes, development was expected to concentrate on activities which would lower transportation and other infrastructural costs. The emphasis in these areas was on self-sufficiency and the production of highvalue crops which would better bear the high cost of transport.

For implementation of the settlement program, the country was divided into 20 regions, with regional boundaries demarcated by soil capability. The classification of regions by soil emphasized the priority accorded to agriculture as one of the most important 
production bases of the economy. However, before the new regional system could be implemented, the government concluded that administration of 20 regions would be too unwieldy and that a more streamlined system was necessary to meet current circumstances. As a result, a new regional system was unveiled in 1973.

The regional system of administration that was introduced in 1973 divided the country into six regions, namely, North West, Essequibo and West Demerara, East Demerara and West Coast Berbice, East Berbice, Mazaruni/Potaro, and Rupununi, with six regional ministers as functional heads for their respective regions (see Figure 5). Besides providing an administrative function, the regional system was expected to be an important institution for social reconstruction and national development. Its primary objective was:

To facilitate and accelerate the process of development, and create self-reliant, confident and productive communities who understand the nature of national development and accept individual and collective responsibility for this task. ${ }^{65}$

A few years after its implementation, it was evident that the new regional administrative framework was unable to attain any of its lofty objectives. The incursion of the regional system on existing local governments and organizational framework for physical and economic planning created confusion and friction among the different layers of

\footnotetext{
${ }^{65}$ Guyana Handbook 1976, p. 45 .
} 
government. It was never very clear whether civil servants were in charge or were beholden to political appointees. Lines of communication were further muddled by the government's effort to unite political and governmental authority in the regions; each regional minister also functioned as chairman of the ruling party's (PNC) regional organization. At the same time, power to finance and implement projects remained firmly in Georgetown. Regional development boards were merely advisory. Even the simplest project had to receive the assent of the Regional Development Ministry in the capital. This led to horrendous delays and subverted any attempts at decentralization. Interior regions were especially neglected, for they failed to garner an equitable allocation of government funds, although on a per-capita basis the disbursements were not quite so inequitable (see Table L).

In introducing the new 1980 regional administrative system, the government uncharacteristically acknowledged that the 1973 regional framework was a failure. The 1973 regional framework, according to the government, had failed to alter the country's pattern of land use, to speed up its development, and to raise the standard of living of the population. In addition, the revised regional system was formulated in 1980 to accompany the promulgation of a new constitution, whose main purpose was to democratize the country's institutions in order to enable greater citizen 
participation in the management and development of their communities. ${ }^{66}$

Article 72 of the 1980 constitution divided the country into 10 regions (see Figure 4). Each region was further subdivided into subregions, districts, communities, neighborhoods, and people's cooperative units. Regional boundaries were demarcated according to population, physical size, geographical characteristics, economic resources, and planned infrastructure for the area. ${ }^{67}$ The resulting boundaries of the 10 regions were found to be natural boundaries, following rivers or watersheds, with each region having an adequate resource base to be economically viable. ${ }^{68}$

Although omitted from the 1980 regional system, the five urban areas of Georgetown, New Amsterdam, Linden, Rose Hall, and Corriverton were expected to cooperate within the regional framework whenever developments occurred which extended across their respective boundaries. Each local authority was accorded the power to do "anything" considered essential to the development of its area and the welfare of

${ }^{66}$ Hoyte, D. 1980. Speech by Comrade Desmond Hoyte Minister of Economic Development and Cooperatives During Debate on the "Local Democratic Organs Bill" in the National Assembly on August 18,1980 . Georgetown: Ministry of Information, p. 3 .

${ }^{67}$ Ibid., p. 8 .

${ }^{68}$ Ibid. 
its people. ${ }^{69}$ The real emphasis was on devolution and decentralization of activities by the central government. By granting greater power to local areas and their people, the government hoped to reduce the deep economic malaise that had gripped the country. The alienation of the work force which appeared to be so prevalent would be lessened if workers in the regions were allowed to produce for their immediate benefit rather than for some far-flung entity. In turn, prosperity in the regions not only would sustain local populations, but would also lure workers away from the capital city.

Commitment to interior development was also boosted by the creation of the Guyana National Service in December 1973. Ostensibly a paramilitary organization, the Guyana National Service was charged with a number of objectives, including one to settle the country's youth (i.e., persons up to 25 years of age) in the hinterland so that the natural resources of the country could be fully exploited for its development. ${ }^{70}$ Initially three hinterland centers were established at Kimbia, Berbice River; Papaya, North West Region; and Tumatumari, Potaro River. Large-scale cultivation of cotton and pineapples was attempted at Kimbia, and blackeye peas and pineapples at Tumatumari, but the results were far from encouraging. All three centers

\footnotetext{
${ }^{69}$ Ibid. , p. 10.

${ }^{70}$ Guyana National Service state Paper, 1973.
} 
were expected to alter unfavorable perceptions of the interior and to imbue Guyanese youths with the wherewithal and skills to break out of the "cramped" coastland. However, whilst exposure to the interior might have fostered a greater awareness of the hinterland, very few Guyanese were ready to make permanent moves away from the coast. Despite its stated intention to settle the hinterland, the government continued to target a large proportion of its resources to the coastal areas, and in particular, to areas of party loyalty. In 1975, the government converted a 200acre sugar estate, Elizabeth Hall, into the country's first cooperative village. Named Melanie Damishana, and located 15 miles east of Georgetown, the village was to be a selfreliant community, housing government supporters from the army, police force, and civil service. By 1980, the government had poured 10 million dollars into the settlement to provide residents with a three-story shopping complex, a school, a day care center, a chicken farm, a garment factory, piped water into all homes, a community hall and pavilion, and other recreational and social facilities. Members of the community were given time off from work by the government, with pay, to enable completion of their homes. ${ }^{7}$ In addition, the estimated 500 householders were allowed to repay their mortgages to the cooperative housing

"Payne, G. 1982. Analysis of a settlement - The Guyanese Situation - Melanie Damishana. In M. Thomas (ed), op. cit., p. 217 . 
society according to their incomes rather than the values of their properties. ${ }^{72}$ For many, this seemed to characterize Guyana's version of "Cooperative Socialism."

\section{Political and social structure}

The state has become increasingly powerful since independence, and the political and bureaucratic elites have become the most important classes in the society. This subsection charts the PNC's control of the political structure through rigged elections in 1968, 1973, 1980, and 1985; the politicization of the military and paramilitary forces; the use of violent cults; the doctrine of the paramountcy of the party; and the resort to violence in order to stifle the opposition and dislodge opponents. The subsection also highlights the dominance of race over class, and it seeks to demonstrate how certain sections of the society have benefitted from the ensuing political and social changes, whilst others have not.

In 1966, Guyana became independent from Great Britain, with the Burnham-led PNC-UF coalition still constituting the government. The coalition, however, was a shaky one; and soon ideological disagreements surfaced between Burnham and the leader of the UF, Peter D'Aguiar. D'Aguiar, who held the Minister of Finance portfolio in the coalition government, became disillusioned by the government's misuse

\footnotetext{
${ }^{72}$ Ibid. , p. 214
} 
of funds to placate PNC supporters in Georgetown. ${ }^{73}$ After discovering that over 20 million dollars of government funds could not be accounted for, D'Aguiar broke away from the coalition, prior to the 1968 elections.

With D'Aguiar out of the way Burnham could independently chart Guyana's future. The departure of the UF from the coalition resulted in a rise in public expenditure, and with it an expansion of the government sector. The PNC was bent on consolidating its power, and this meant that its policies were designed to accrue mainly to middle-and lower-income Africans in the urban areas. Africans, with help from the PNC, were being increasingly employed in the civil service, the police force, and the military. The PNC's strategy of peopling the machinery of the state with supporters of the party was a deliberate one, to ensure victory at the polls and to hold on to the reins of power.

The 1968 elections were a triumph for Burnham and the PNC. After four years in power, the PNC was able to establish political dominance by transforming the minority of the pre-independence elections into a majority in the 1968 elections. According to the official results, the PNC captured 30 of the 53 contested parliamentary seats, the PPP won 19, and the UF 4. The sanctity of the elections was

\footnotetext{
${ }^{73}$ Spinner. T. 1984. A Political and Social History of Guyana, 1945-1983. Boulder, Colorado: Westview, p. 121.
} 
widely disputed. The opposition and many independent observers have documented widespread rigging of the electoral lists. Along with padding the voters' list, widening the provisions for proxy voting, and tampering with the ballot boxes, a special feature of the rigging was the use of overseas voting. Guyanese residents overseas were allowed to participate in the elections, irrespective of the time they had lived abroad. Altogether, over 70,000 overseas voters were added to the voter register by this electoral device. The opinion Research Centre, a reputable English firm, estimated that, of the 44,295 overseas voters registered in Great Britain, only 15 percent of the encries on the register were valid. ${ }^{74}$ The director of the firm, Humphrey Taylor, summing up his company's findings in an interview, concluded:

Obviously I don't know what happened in Guyana, but as far as Britain is concerned, the compilation of the register was a totally dishonest and corrupt operation. And, as we have clearly established, the great majority of the people listed, do not exist. This I would think is unprecedented for a Commonwealth country, as far as I know; and it's you know, a pretty awful and disgraceful episode. ${ }^{75}$

The scale of the fraud was substantiated in two documentaries by Britain's Granada Television Company, which also found similar abuses in the United States. Within

${ }^{74}$ Latin American Bureau. 1984. Guyana: Fraudulent Revolution. London: Latin American Bureau, p. 49.

${ }^{75}$ Tennassee, P. 1982. Guyana: A Nation in Ruins. The puerto Rican Model Failed. Toronto: Guyanese Research \& Representation Services, pp. 26-27. 
Guyana, names of infants, the deceased, and those who never existed were to be found on the electoral rolls. On the other hand, names of thousands of Indian voters were omitted from the rolls. This stratagem produced some interesting results in Guyana. Between the 1964 and 1968 elections, the number of registered voters increased by a whopping 21 percent, whereas in the previous election period (1953-1964) the increase was only 18 percent, despite a much longer lead time. The distribution of the increases is particularly revealing. In six Indian-dominated areas on the corentyne, the average increase was 10 percent, while in the PNC strongholds of Linden, Mazaruni-Potaro, and Abary the increases were 105 percent, 55 percent, and 49 percent, respectively. ${ }^{76}$

The policy to people the machinery of the state with supporters of the party had paid off handsomely. It was quite an endeavor to perpetuate such a large-scale fraud, and this obviously required the cooperation of the bureaucracy. With power firmly in its grasp, the PNC embarked on a program to lure top-level politicians from the PPP and the UF into its fold, and to gain the support of certain sections of the business and religious communities. In these efforts, the party was quite successful. A number of politicians were recruited from the opposition and were given prominent positions in the government. Certain

\footnotetext{
${ }^{76}$ Ibid. , p. 25.
} 
members of the business community openly began to express their allegiarce to the PNC, and were rewarded with government contracts and access to licenses and other government privileges. Business leaders who refused advances by the government were effectively squeezed. $n$ Many found life unbearable and left the country. ${ }^{78}$ Powerful figures in Indian cultural and religious organizations such as the Maha Sabha, the United Sad'r Islamic Anjuman, and the Gandhi Youth organization were co-opted, and as a result transferred their organizations' support from the PPP to the PNC. ${ }^{79}$ Hintzen adds:

Thus, clientelism served the interests of the PNC regime by acting effectively to demobilize the political opposition and to co-opt the leaders of strategic mass-based organizations. With the co-optation of these leaders, their organizations were no longer available to be used for mounting challenges to regime power. ${ }^{80}$

On February 23, 1970, Guyana was declared a

nDanns, G. n.d. "The New Elites in a silent Revolution." Unpublished paper (University of Guyana), p.21. According to Danns: To survive private sector elites are constrained to bribe the state and public sector elites and to pay off political elites or else give big donations to the ruling party. Unwillingness to give bribes, gifts and donations will more than likely result in the loss of business in one way or another.

${ }^{78}$ Ibid.

${ }^{79}$ Hintzen, P. 1989. The Costs of Regime Survival: Racial Mobilization, Elite Domination and control of the state in Guyana and Trinidad. New York: Cambridge University Press, pp. 70-71. Hintzen claims are supported by Danns (n.d. The New Elites etc., p. 24).

$$
{ }^{80} \text { Ibid., p. } 71 \text {. }
$$


Cooperative Republic. Cooperatives were perceived by the government "as an alternative to Jagan's communism and D'Aguiar's capitalism."81 And, since they existed not only in the East but in the capitalist West, the government surmised that its new direction was unlikely to provoke international capital and members of the comprador bourgeois class in the country. The government could also argue that the cooperative ethic had a long historic tradition in Guyana. Elements of cooperativism are an integral part of Amerindian society. In the post-emancipation era, freed slaves had established cooperative villages, and Indian indentured laborers had made the transition to rice farming through cooperative endeavors. ${ }^{82}$ Burnham elucidated his conception of cooperativism in the following way:

The cooperative is the means through which the small man can become a real man, the means through which the small man can participate fully in the economic life of the nation, and the means through which the small man can play a predominant part in the workings of the economy. ${ }^{83}$

Burnham's concern for the "small man" was ostensibly an effort to appease the left wing of the party by reaching out to lumpen and lower-class Africans in the urban areas who had not benefitted from the existing economic strategy.

${ }^{81}$ Spinner 1984 , op. cit., p. 136.

${ }^{82}$ Lutchman 1974, op. cit., p. 244.

${ }^{83}$ In Hope, K. 1985. Guyana: Politics and Development in an Emergent Socialist state. Oakville, Ontario: Mosaic, pp. 8384 . 
Thus, cooperatives were expected to provide this class of workers with the impetus to tap the agricultural wealth of the country.

Cooperative socialism reinforced the PNC's hold on the state. Having long destroyed the old white ruling group, the PNC sought to utilize the state in order to maintain African control of Guyana. Cooperative socialism in Guyana was a triumph of politics, for it widened the country's political elite grouping by increasing the role of the state in the society. As the political and bureaucratic elites thrived, ethnic cleavages were reinforced. The PNC used its control to fill positions in the nationalized industries and in the government mainly with its African supporters. One observer in the 1980s noted:

....it would seem that Afro-Guyanese comprise more than sixty percent of the total number of civil servants and occupy more than eighty percent of the senior positions. ${ }^{84}$

Racial divisions and the small number of people in the country have prevented political mobilization on the basis of unified class interests. For example, despite similar socioeconomic interests, the African urban lower class and the Indian rural lower class have never constituted a political alliance in the post-independence era.

As mandated by the constitution, elections were held in 1973. Once again the PNC was victorious, but this time

$$
{ }^{84} \text { Hope 1985, op. cit., p. } 35 .
$$


the party claimed 37 of the 53 seats in parliament, or a whopping 70 percent of the votes cast. The independence constitution of Guyana closely resembled the typical Westminster-style commonwealth constitution. Constitutional changes and provisions in many cases could be altered only by a two-thirds majority in parliament. The PNC spent the months preceding the elections informing the public that it was assured of a two-thirds majority. Prior to polling day, the government announced substantial pay increases to civilservice employees and those in the military and paramilitary groups. Confident of victory, the government permitted a radio broadcast of the elections and even allowed an impartial count of the votes in areas of Georgetown which were considered PNC territory. The initial results,

- however, were far from what the party had expected. A low turnout at the polls in Georgetown had resulted in limited support for the party. Embarrassed by the turn of events, the government pulled the election broadcast off the air; and the army, which had become increasingly politicized, was ordered to seize all ballot boxes. The ballot boxes were taken to army headquarters, where they were kept for 24 hours, and where it is widely believed they were tampered with to produce the desired results. ${ }^{85}$

In an effort to shore up its dwindling support among urban Africans, the PNC immediately took steps to ensure its

\footnotetext{
${ }^{85}$ Sunday Graphic, July 22, 1973.
} 
survival. In line with this strategy, Burnham in December 1974, at a Special Congress of the PNC at Sophia in Georgetown, announced the doctrine of the paramountcy of the party. Commonly known as the Declaration of Sophia, the doctrine proposed that henceforth all institutions of the state, including the government, would be considered arms of the PNC and beholden to its dictates. According to Burnham: ..the emphasis should be on mobilising the nation in every sphere and not merely for periodic elections and in support of specific actions and programmes. It was also decided that the party should assume unapologetically its paramountcy over the government which is merely one of its executive arms.

The comrades demanded that the country be given practical and theoretical leadership at all levelspolitical, economic, social and cultural - by the PNC which had become the major national institution. ${ }^{86}$

The Declaration was followed by a period of nationalization of various industries, which met with strong approval by the African bureaucratic middle class who were reaping the benefits of higher salaries, more jobs, and a greater role in running the country. Aided by favorable international prices for the country's major commodities, the PNC was in a position to deliver the spoils to its supporters in the early 1970s. State expansion continued unabated.

The militarization of the society which followed the Paramountcy Doctrine provided an entree for lower-class Africans to obtain employment in the newly created National

\footnotetext{
${ }^{86}$ Burnham 1974, op. cit., p. 11.
} 
Service, the People's Militia, and the growing military and police forces. African youths from the urban areas were despatched into the interior to work on land settlement schemes; but because they had little knowledge of farming practices, most of the schemes quickly fell into disuse. By 1976, it was estimated that 1 in 35 of the population were members of the military or paramilitary forces; and of this number, 90 percent were Africans. ${ }^{87}$ For the non-African community, these were fearful times. In addition to the level of militarization in the society, a number of violent cults, including the People's Temple and the House of Israel, were permitted to operate in Guyana in return for. their allegiance to the PNC. Indians were particularly perturbed by the activities of the House of Israel, whose African-American leader David Hill (alias "Rabbi Washington"), was a fugitive from the FBI. Hill, who claimed christianity to be a white religion and practiced a form of African-Judaism, preached of an impending Guyana apocalypse in which Indians would be destroyed. Unlike the People's Temple, the House of Israel drew its support from African-Guyanese, primarily those who were unemployed. Burnham often used the group to disturb rallies and demonstrations by his political opponents, to break strikes, and to demonstrate in favor of the government.

The People's Temple operated much differently than the

${ }^{87}$ Latin American Bureau 1984, op. cit., pp. 54-56. 
House of Israel. The cult on the whole stood apart from Guyanese society. Most Guyanese simply did not know of its existence. The government, however, found it useful for the simple fact that its members were American citizens who had agreed to settle an area which was in dispute with Venezuela. The government held that in the event of an invasion by Venezuela, the United states would move to support its citizens and in turn this would benefit Guyana. Elections were due to be held in 1978, but the PNC introduced a referendum bill in April 1978, to legitimize the paramountcy doctrine, which was contrary to the provisions of the constitution. The party argued that the intent of the bill was to end the provision in the constitution which allowed changes of the constitution only through a referendum, and to transfer the responsibility to a two-thirds majority in Parliament. However, the PNC already had a two-thirds majority in Parliament and could enact wide-ranging legislation; and since the bill did not state any specific amendments of the constitution, the opposition concluded that the real intent of the referendum was to extend the life of Parliament by side-stepping the constitutionally mandated elections.

To stifle some of the criticism of the necessity of the referendum bill, the PNC later suggested that if it were to win the referendum it would turn Parliament into a constituent assembly in order to completely revamp the 
existing constitution. The move failed to suppress widespread opposition to the bill from the established churches and civil and professional groups. Lawyers opposed to the bill claimed:

1. It strikes at the root of democracy and is an infraction of the existing constitution not to hold elections now under that constitution. It would be unconstitutional.

2. The holding of the Referendum in the dying hours of the life of the present Parliament is a cloak to conceal the real intent which is the postponement of elections.

3. Even if a majority or a bare majority approved of the Bill, this does not entitle the existing government's two-thirds majority to proceed to amend the constitution after its life will have expired. It will be morally and legally wrong to do so.

4. If since 1974 the Government or the Governing Party had embarked on drawing up a new constitution in respect of which guide lines approved by their General Council on 27 th May, 1978 were first published on 31st May, 1978, it will conceivably take the country (only now invited to submit drafts) a long time to work out an agreeable constitution.

5. Such elections will determine whether the Governing party still enjoys a two-thirds majority support of the electorate. The duty properly belongs to the newly elected Parliamentarians to draw up a new constitution. 88

Just about every major group or organization called for a boycott of the referendum. Even the African middle class, who had traditionally supported the party, were opposed to the proposed changes. The ensuing boycott,

${ }^{88}$ Supplementary memorandum by the 108 (of 135) lawyers opposed to the Constitution (Amendment Bill, 1978) - In answer to certain points canvassed in support of the aforesaid Bill and in defence of the attack made on lawyers. Pamphlet. June, 1978 . 
according to the government, was an abject failure. It was announced that 71.45 percent of the electorate had turned out and 97.7 percent had voted in favor of the bill. Most opposition groups which had independently monitored the elections reported the actual turnout at 14 percent, whilst the PPP estimate was as low as 12 percent. ${ }^{89}$

In the wake of the referendum, the government (as expected) decided to extend the life of Parliament for 27 months, on the basis that Parliament needed enough time to complete the proposed constitutional changes. The new constitution was finally promulgated in 1980. Acknowledging its faltering support among urban Africans, the PNC took steps to ensure its supremacy over the society without dependence on a popular base. As the country's first executive president, Burnham was given virtual imperial powers by combining the powers of the president and the prime minister.$^{90}$ Besides orchestrating the election process, the constitution made it almost impossible to remove the executive president from office without his consent; even in the event of criminal charges or misconduct, the president was virtually immune:

..the holder of the office of President shall not be personally answerable to any court for the performance of the functions of his office or for any act done in the performance of those functions and no proceedings, whether criminal or civil,

\footnotetext{
${ }^{89}$ Mirror, October $14,1979$.

${ }^{90}$ The Guardian (England), June 16, 1980.
} 
shall be instituted against him in his personal capacity in respect thereof either during his term or thereafter. ${ }^{91}$

In addition to the dictatorial powers accorded Burnham, the 53 elected members of the National Assembly were augmented by 12 additional members, 10 of whom were from the newly created regions.

Elections were held in December 1980, and once again the PNC awarded itself a resounding victory. An observer team led by Lord Avebury of Britain could only conclude:

We came to Guyana aware of the. serious doubts expressed about the conduct of previous elections there, but determined to judge these elections on their own merit and hoping that we should be able to say that the result was fair.

We deeply regret that, on the contrary, we were obliged to conclude, on the basis of abundant and clear evidence, that the election was rigged massively and flagrantly. Fortunately, however, the scale of the fraud made it impossible to conceal either from the Guyanese public or the outside world. Far from legitimizing President Burnham's assumption of his office, the events we witnessed confirm all the fears of Guyanese and foreign observers about the state of democracy in that country. ${ }^{92}$

The months preceding the elections were marked by strikes and demonstrations. Popular discontentment was at an all-time high. Indian sugar workers and African bauxite workers, the two major groups of the industrial working class, were simultaneously opposing the government for the

\footnotetext{
${ }^{91}$ Constitution of the Cooperative Republic of Guyana, 1980, Article 182 (2), pp. 93-94.

${ }^{92}$ The Report of the International Team of observers at the Elections in Guyana. 1980. Something to Remember. In Latin American Bureau 1984, op. cit., p. 83 .
} 
first time. The fact that the government had lost the support of the bauxite industry was validation of its unpopularity.

In addition to strikes by the country's labor unions, the government for the first time in many years was challenged by a multiracial party, the Working People's Alliance (WPA) . Formally constituted as a political party in 1979, the WPA was a Marxist-oriented organization led by a group of intellectuals from the University of Guyana and other progressive professionals. The party's multiracial character and its independent Marxism quickly drew broad support from the Guyanese masses (as was evidenced by the party's well attended rallies), who were dissatisfied with the perceived racial orientations of the established parties.

Although professing a collective leadership, Dr. Walter Rodney, a world-renowned scholar and a powerful and eloquent orator, was the de facto leader of the WPA. Rodney's wit and activist background energized the WPA. In rapid fashion, the party's rallies attracted thousands of Guyanese from all points of the ideological spectrum. Fed up with the economic and political deterioration of the country, many saw Rodney as the only person capable of effectively challenging Burnham. BY June 1980, the PNC was on the run. The ground swell of opposition was so strong that the general feeling in the country was that the PNC's 
days in office were numbered. There were widespread demonstrations in all of the major populated areas. Its hold on power threatened, the PNC responded with a campaign of violence, which resulted in the assassination of Rodney on Friday, June 13, 1980. The loss of Rodney was a severe blow to the WPA, and the party has continued to lose ground since this tragic event.

Having declared itself the victor in the 1980 elections, the PNC and Burnham continued to intimidate its opponents. Buttressed by military and paramilitary groups, with the press under its control and Parliament little more than a rubber stamp, the PNC managed to weather the unrest unleashed by the Guyanese masses. In August 1985, however, the death of Burnham whilst undergoing what was thought to be a routine throat operation, presented the country with fresh possibilities. Burnham's successor, Desmond Hoyte, initiated a number of steps to reduce the politics of confrontation, and there was some belief that the forthcoming elections in December 1985 would be the first free and fair elections in the independent nation's history. The result of the 1985 elections was a grim reminder that little had changed with the passing of the torch from Burnham to Hoyte. Many had forgotten that Hoyte had been in the government since 1968, and had served in just about every cabinet position. Speaking about the PPP at the Annual Congress of the PNC in 1973, Hoyte had openly boasted 
that "they have been removed from office by the Guyanese people - never to return!"93 Being part and parcel of the dictatorial PNC regime, Hoyte had no intentions of relinquishing power. The 1985 elections were said to be the most flagrantly rigged elections in the country's history. ${ }^{94}$ Criticism of the elections was widespread. The turnout in the urban areas, the party's traditional stronghold, was low, and this poor turn out led to a three-day delay in the counting of the votes. When the results were announced, the PNC had miraculously secured 42 seats, the PPP eight, the UF two, and the WPA one.

After the elections, Hoyte became more conciliatory to the opposition. There was some talk of power sharing. The economy has become more open and Hoyte has sought to repair relations with the United states. The mass media, which was once muzzled, has been augmented by the introduction of an independent newspaper. Political and daily life is now less claustrophobic, and the element of fear which was so pervasive has been somewhat dispelled. However, the party refuses to let the masses control the destiny of the country. Elections should have been held in 1990, but as of June 1992, no firm date has been set. It seems that the

${ }^{93}$ Hoyte, D. 1973. The Great Advance in Infrastructure Development Under the PNC Government. Address by Desmond Hoyte, Minister of Works and Communications, at the 16th Annual Delegates Congress of the PNC, p. 15.

${ }^{94}$ Catholic standard, December 15, 1985. 
newer liberal policy of the government does not extend to the political system.

\section{SUMMARY}

Guyana attained independence and full dominion status on May 26, 1966. During the pre-independence era, the distinctive form of colonial organization was a centralized politico-economic system of plantation exploitation, with economic structures and institutions fashioned towards metropolitan countries. With the advent of independence, it was felt that the old imperial influences and economic orientation would be rearranged. Independence would ensure freedom and the capacity of the national socioeconomic system to operate with wider internal goals. To date, this has not been borne out. The achievement of independence from Great Britain has resulted in minimal change in the country's linkages. Guyana's economy continues to be tied to the global economic. order in virtually the same manner as it was in the early twentieth century. The country remains an exporter of raw materials and an importer of manufactured and finished goods.

The quixotic attempt at "cooperative socialism" in the 1970s was an unmitigated disaster. As the economy nosedived, the government extended a wizened hand for assistance from the IMF-World Bank Group. The stabilization programs imposed by the Group were antithetical to the adoption of 
socialist policies, and it is questionable just how serious the government was in its desire to establish "cooperative socialism" in Guyana. The country was unlikely to achieve socialism if it was to be built on the privatization of the public sector and deregulation of the economy to market forces, which the IMF-World Bank Group advocated. In effect, the IMF-World Bank Group measures have reinforced the country's linkages to the core and dependence on its traditional exports of sugar, bauxite, and rice-factors which were part of the cause of instability in the first place. Thus, in 1989, the three commodities still accounted for 70 percent of the country's export earnings, whilst Britain, the United States, and Canada comprised 60 percent of the export market. ${ }^{95}$ Furthermore, the Group's policies have paved the way for the return of transnational enterprises which previously dominated Guyana's economy, including those such as Bookers and Reynolds.

The struggling economy relegated urban planning, and physical planning in general, to the background. With so much of the capital expenditure budget tied to financial transfers, the urban and rural areas were both to some extent neglected. However, in the early years of the postindependence period it was blatantly obvious that development was being targeted to urban areas where the

\footnotetext{
${ }^{95}$ World Economic Data, 1991. Santa Barbara, California: ABC-CLIO, pp. 82-83.
} 
government could claim its greatest support. The argument that the government was neglectful of its rural population was bolstered by an examination of urban/rural differentials concerning the provision of infrastructure and access to public services. And, while the urban/rural divide was not created by the post-independence regime, the data presented indicated that inadequate steps were taken to rectify the inequities.

One hopeful measure in reducing spatial inequalities was the introduction of a regional system of administration; but after 19 years and several revisions, the regional framework has yet to fulfill its potential promise. Although it is embodied in the constitution, regional policy has lacked direction. Decentralization and devolution have proven to be elusive. Regional governments have become merely centers of administration, maintaining and providing services within their boundaries. There is no evidence that locals are more involved in the planning process. Indeed, in regions where plans exist, access to planning information is often denied. Bottom-up planning in Guyana has become a technocratic exercise, in which those who are most affected by the plans are excluded from the process.

Regional self-reliance absolves the central government of its responsibility to provide resources to certain regions, whilst it allows others to be practically ignored. Thus, since 1966, the uneven settlement structure and the 
country's land use have remained virtually unaltered. Certainly, there is no evidence that population flows into the interior regions have increased. Even the muchballyhooed settlement schemes, which were thought to be essential for "bursting into the interior", have all but been abandoned.

Development, what little there is, takes place on an ad hoc basis, in which just about anything goes. Georgetown has not escaped the tough times. The capital's infrastructure has almost collapsed. The "Garden city" of the Caribbean has become a festering wound. Signs of neglect are pervasive. Refuse is dumped indiscriminately, clogging the city's drains and polluting the once-beautiful canals. Nevertheless, Georgetown remains at the apex of the settlement hierarchy, and it is still the only significant population center in the entire country. 
CHAPTER VI

CONCLUSION

The preceding study has been concerned with the process of urbanization and urban growth in Guyana during a significant portion of the nation's history. In an effort to facilitate understanding of the Guyanese space economy, this study employed a theoretical framework based on the international political economy of the dependency/worldsystem perspective. This perspective, associated with the works of Frank (1966, 1967, 1978a, 1978b, 1980), Emmanuel (1972), Rodney (1972), Amin (1974), and Wallerstein (1974, $1976,1977,1979,1980,1984)$, among others, and linked to urban development by Castells (1977), posits the view that dependent urbanization arises as a result of capitalist penetration and expansion.

There is no formal theoretical model of dependency/world-system theory. However, the typical dependency/world-system position sees the peripheral economy being shaped through its Iinkage with the capitalist core economies. This linkage formed through systemic financial, technical, and cultural penetration has produced a number of 
specific characteristics in dependent nations. The dependent economy, according to the perspective, is marked by an overarching reliance on foreign trade with a limited number of trading partners, and a concentration on a small number of products for export.

The narrow, outward-looking economic orientation of the dependent economy in turn produces uneven development, whereby those sectors of the economy which are directly associated with international capital appear to be more dynamic in their levels of economic activity. It also results in the disarticulation of the economy, with few linkages between the various sectors; for example, goods produced for export are not integrated with those catering to the domestic economy. And, finally, there is a high level of sectoral heterogeneity which results in differing returns from labor|across the industrial structure, (Duvall, et. al., 1981:316-317; Sylvan, et. al., 1983).

Although dependency/world-system theory is chiefly concerned with the economic structure of dependent countries, distortions in the political and social structure are also anticipated. Foreign capitalist penetration and dependence is expected to give rise to coercive authoritarian regimes which are considered necessary to mediate class conflicts and to prevent the ascendancy of the working class.

This brief outline is only an explication of those 
parts of the dependency/world-system perspective that I believe to be most useful in understanding urbanization in peripheral economies. It is intended to serve as a general guideline to direct our attention to important matters in the history of urbanization in Guyana.

The preceding study acknowledges the importance of the international political economy in determining the nature and consequences of urbanization in Guyana, and for the most part it has used dependency/world-system theory to explain events in the country's urban history.

In surveying the components shaping urbanization, the study discerns outcomes which essentially confirms the expectations of dependency/world-system theory. Following its incorporation into the modern world system in the sixteenth century, Guyana has reproduced many of the patterns of development that are expected of a dependent peripheral economy. The dependency/ world-system theory framework of analysis is especially strong in uncovering how global linkages between Guyana and the core have resulted in internal economic distortions. The study has noted the existence of the following:

1. Trade partner concentration and a reliance on foreign markets. Most of the country's trade is heavily dependent on the United States, the United Kingdom, and the Caricom countries. Market concentration is highlighted by the fact that the United Kingdom is the chief recipient of Guyana's 
sugar, the United States and Canada the chief recipients of Guyana's bauxite, and the Caricom the chief recipient of Guyana's rice. The country's imported goods also originate overwhelmingly from the above four major trading partners. 2. Concentration of commodities exported: Three commodities in the agricultural and extractive sectors dominate the export market. In 1989, exports of sugar, rice, and bauxite still accounted for 70 percent of total export earnings.

3. Trade vulnerability: Guyana's dependent economy and its incornoration into the world system has meant that the narrow economy is subject to external events, particularly conditions at the center. Unstable markets, price fluctuations, unequal terms of trade, and metropolitan economic policies dominate events in Guyana.

As a result of the above factors, Guyana, in line with the expectations of dependency/world-systems theory, exhibits a number of major structural distortions of its economy. These include:

1. Uneven development across sectors: Sugar, rice, and bauxite, despite the economic difficulties confronting these industries, must still be considered the most "dynamic" sectors of the economy.

2. Disarticulation: The intermediate links thought necessary to invigorate the dynamism of the industrial structure are still lacking. Linkages between the various 
sectors of the economy have not changed in spite of (or perhaps because of) the adoption of capital-intensive methods of production in the sugar and bauxite industries. 3. Heterogeneity of the return to productive factors across sectors: With a limited number of dynamic sectors and a dependent economy, the returns of labor across economic sectors remain uneven.

In stressing the importance of global linkages, the dependency/world-system perspective is particularly adept at pinpointing geopolitical rivalries anong competing core nations and their impact on Guyanese urbanization throughout the study's delineated eras of Guyanese history. our historical examination clearly demonstrates that urbanization in Guyana was the product of colonial economic and class structures. That is, settlement configuration in Guyana since the European incursion was based upon Holland's, France's, and particularly Great Britain's geographical expansion, and upon the capitalist mode of production on a world scale.

Guyana was organized for the export of primary products, which resulted in the transfer of surplus value to the metropolitan economies. Spatial organization in Guyana commenced with the needs of mercantile Holland. The Dutch introduced the plantation system into Guyana, from which they were able to extract an agricultural surplus. However, they were not interested in urban development. Urban 
development under the Dutch was wholly absent; and since each plantation was directly linked to the core, there existed little need for the integration of the space economy at a national level.

The French were far more willing to build up the urban hierarchy; but since they were not up to the task, it was left to the British to fashion the country's urban centers. It is important to note that British domination did not bring significant changes to Guyana's internal industrial structure or social relations. The plantation remained the foremost medium for capital accumulation and value transfer, and Guyana steadfastly continued to direct its surplus to the core. However, in time, the intensification of capitalist forces, organized around the production and commercialization of sugar, led to the formation of an immature urban network. The foundation and growth of Georgetown is thus explicated by the processes of penetration, capital accumulation, and value extraction and transfer.

Spatial organization under British colonialism revolved around the need to achieve an efficient and reliable exploitation of primary products at minimal cost. Hence, planning, infrastructure allocations, and related investments were geographically centered on Georgetown - a single location not only capable of port, commercial, administrative, and political functions, but also capable of 
functioning as an economic link between the core economies and the sources of primary production, the plantations.

Core power hegemony under the British, therefore, led to the stimulation and growth of the port town of Georgetown and the secondary port of New Amsterdam. Georgetown, the capital, in particular was used not only to evacuate expeditiously economic surplus, but also to provide a market for the manufactured goods produced in industrial Britain. The horizontal spread of the colonial port city as a result was facilitated through the introduction of railways, roads, trolley systems, and other infrastructures.

Thus far, the evidence tendered appears to be highly supportive of the theory, and is congruent with the theoretical predictions relating to the effects of world capitalist penetration. Certainly, the strength of dependency/world-system theory lies in its ability to show how global linkages shape internal development in the dependent state. Confirmation of a number of dependency/world-system propositions, however, does not mean that the approach should be embraced unequivocally. What it does suggest is that the approach should be taken seriously in any attempt to forge an understanding of urbanization in peripheral capitalist states.

Unlike Galtung's (1971) center-periphery model, which focuses its attention on interactions among governments, the dependency/world-system framework, in addition, concentrates 
on the global interactions of nonstate actors, such as TNCs, banks, and the IMF. These sources of external capital have continued to perpetuate uneven development. Benefits from foreign investment and aid redound to the "modern" sector and to the few elite groups in the society which benefit from the process. This is true even in cases where the primary beneficiaries of aid appear to be those with the most urgent needs.

By situating Guyanese urbanization in the context of changes in the world system, this study has moved beyond many previous investigations of cities in the developing world, which have described urban processes within a national setting and have steadfastly omitted the effects of global linkages. Unfortunately, academics who have embraced the dependency/world-system perspective have been so enamored with dependency relations that they have conversely failed to consider internal structures.

Whilst the dependency/world-system framework allows one to clearly demonstrate how surplus value was extracted from Guyana via the circulation of agricultural and mineral commodities, it failed to adequately address the manner in which labor was utilized and reproduced.

By concentrating on the politicoeconomic structure at the global level, dependency/world-system theory seems to have presented us with a reductionist argument, since it failed to consider the importance of local forces. The 
perspective does not adequately account for local variations in the political and social structure of the peripheral economy. It consistently appears to underestimate the role of the local state, as well as the power of local elites, classes, ethnic, political, and interest groups in determining urbanization outcomes.

It is obvious that investigations about development and urbanization in the Third World must journey beyond the dependency/world-system perspective. My modest attempt in this direction entails a recognition of internal politicosocial variables. At the level of the national political economy, the local state does appear to have some degree of impact on urbanization and settlement patterns. Cognizant of the previously outlined weaknesses of dependency/world-system theory, the study endeavors to consider not only the domestic class structure, but also the distortions engendered by ethnic conflict in Guyana. It is imperative to understand that penetration of capitalism into the country was not a pain-free process. The inherent contradictions between labor and capital did take place, but for the most part, the class struggle has been overshadowed by long-standing ethnic conflicts.

Whilst one might argue that dependency/world-system theory does at least consider class relations at the global level, ethnicity is thought to be irrelevant in matters relating to development. Rather, it is simply believed to 
be a reaction to world capitalist penetration.

Urbanization in Guyana is contingent not only upon the class struggle, but also ethnic/racial conflict. Throughout the study, the historical evidence has supported the notion that race has been a dominant factor in the internal political economy. Racial considerations have been most important in determining the execution of legislation, the allocation of economic surplus, planning, and development policies which have impacted urbanization. The local state, although it was always in the final analysis, beholden to the supreme authority of the colonial powers prior to Guyana's independence, has always reflected the political will of the dominant ethnic group. This in turn has led to policies which seek to benefit particular group members. Factionalism is deeply embedded in the society. For the white planter class and the East Indians, control of the state has meant a preoccupation with rural areas, whereas for Africans the emphasis has been an urban one.

Therefore, to understand the role of the state in Guyana, and how government policies, infrastructural allocations, and planning have affected urbanization and settlement patterns in the country, this investigation has analyzed not only how ethnicity was impacted by capitalism, but also how it interacted with this particular mode of production in the domestic space economy. Its effects on internal causation are traced by addressing decisions 
related to infrastructural allocations and planning.

The conclusion that the Guyanese social formation was dependent on linkages to the core, and the resulting complex of urban problems which this provoked, is at odds with the more optimistic predictions of modernization theorists such as Rostow (1962), Reissman (1964), Sjoberg (1965), Berliner (1977), and Browett (1980). The expectation that urbanization in developing countries such as Guyana would progress along a linear continuum already travelled by Western Europe and North America has not materialized. Urbanization in Guyana has proceeded in the absence of economic growth and industrialization.

Guyana today appears to conform more closely to the postulates of dependent urbanization. Among the observed contemporary characteristics of the urban structure are urban primacy, unemployment and underemployment, a burgeoning informal sector, intra-urban inequality, shanty towns and squatter settlements, and retardation in rural areas. These dependent urbanization features have also been accompanied by a number of conditions that appear to be common to all countries which have experienced dependent development following their incorporation into the modern world system. Within the economic structure, the research has noted an overwhelming raw-material export orientation with product elaboration in the core, low rates of GNP and per capita incomes, a stunted manufacturing sector, a lack 
of diversification, low-productivity and low-wage labor, excessive dependence, a deepening divergence between what is consumed and what is produced, and the absence of an internal dynamic and coherence. Within the political and social structure, the study has noted perceived racial and ethnic divisions, a high degree of social segmentation, residential separation along racial lines, profound inequalities, instability, bureaucratism, and authoritarian tendencies.

Whilst there appears to be nothing singular in Guyana's dependent urbanization experience in relation to other developing countries which have been integrated into the world capitalist system, there is one noticeable difference. Rural-urban migration has not occurred on the scale so much in evidence elsewhere in the developing world. Save for a brief spurt in the post-World war II period, the rate of rural-urban migration in the twentieth century has been decidedly slow, and at the present time it has almost ground to a halt. How can dependency/world-system theory explain this anomaly?

One possible answer is that Guyana has successfully reduced its dependent position in the world capitalist system. But, as we have already noted in chapter $V$, the country's industrial structure and its global economic linkages have remained largely unchanged in the postindependence era. The major change, however, has been the 
deterioration of the economy, which has led to the crerall neglect of the space economy. Whereas in the past a significant proportion of rural residents moved to the more vibrant capital city of Georgetown, they now move to urban areas in the core or to urban places where dependent capitalism is in ascendancy. Through emigration, large numbers of rural inhabitants are voting with their feet by moving directly overseas. Global cities such as Miami, New York, and Toronto have become the prime attractors of Guyana's rural and urban populations.

What should be learned from Guyana's attempt to alter spatial patterns through self-reliance and cooperative socialism? The dependency/world-system framework indicates that the failure of the strategy can be explained in relation to structural changes in the global economy. Specifically, the strategy's lack of success is attributed to the unequal nature of the terms of trade - rising prices for imports of energy, manufactured goods, food, and capital; falling prices for exports of agricultural and mineral products. The theory also suggests that Guyanese cooperative socialism merely sought a nationalist accommodation in the world capitalist order. Dependency relations continued in much the same manner. The same dynamic of producing what is not consumed, and consuming what is not produced, prevailed. Finally, the arrival of the IMF and World Bank on the scene, armed with their open- 
door and export-led policy prescriptions, firmly sealed the fate of Guyanese self-reliance.

Whilst the above explanations are correct, they are at the same time inadequate. Failure of self-reliance cannot be attributed solely to external reasons. My analysis of the Guyanese development complex clearly points out that endogenous forces also played an important part in the demise of the self-reliant strategy. Ethnic conflict, factionalism, clientelism, mismanagement, repression, the lack of skilled personnel, and so on, interacted with exogenous forces to ensure failure. Finally, this study of the Guyana experience demonstrates that dependency/world-system theory can be a powerful heuristic tool in organizing, understanding, and explaining the nature of the urbanization process in a peripheral capitalist state. The research further suggests that when the theory is supplemented with a realist perspective that places a premium on internal dynamics, the dialectical relationship between external and internal forces will ensure a more complete analysis of urbanization in peripheral social formations. 


\title{
SELECTED BIBLIOGRAPHY
}

\author{
BOOKS AND ARTICLES
}

Abbott, C. and S. Adler. 1989. "Historical Analysis as a Planning Tool. Journal of the American Planning Association 55(4):467-473.

Abu-Lughod, J. and R. Hay (eds.). 1977. Third World Urbanization. Chicago: Maaroufa Press.

Adamson, A. 1972. Sugar Without Slaves: The Political Economy of British Guiana. New Haven: Yale University Press.

Almond, G. 1987. "The Development of Political Development." In $M$. Weiner and $S$. Huntington (eds.), Understanding Political Development. Boston: Little, Brown.

Amin, S. 1976. Unequal Development: An Essay on the Social Formations of Peripheral Capitalism. New York: Monthly Press Review.

--- 1980. Class and Nation, Historically and in the Current Crisis. New York: Monthly Press Review.

--- 1990. Delinking. Towards a Polycentric World. London: Zed Books.

Armstrong, W. and T. McGee. 1985. Theatres of Accumulation: Studies of Asian and Latin American Urbanization. New York: Methuen.

Augier, F. and S. Gordon. 1962. Sources of West Indian History. Bristol: Longman.

Bacchus, M. 1980. Education for Development or Underdevelopment?: Guyana's Educational System and it's Implications for the Third World. Waterloo, ont.: Wilfrid Laurier University Press. 
Bach, R. 1980. "On the Holism of a World-Systems Perspective." In T. Hopkins and I. Wallerstein (eds.), Processes of the World-system. Beverly Hills, Calif.: Sage.

Banuazizi, A. 1987. "Social-Psychological Approach to Political Development." In M. Weiner and S. Huntington (eds.), Understanding Political Development. Boston: Little, Brown.

Barker, A. 1968. Development Planning and Plan Implementation in Guyana. Georgetown, Guyana.

Beckford, G. 1972. Persistent Poverty: Underdevelopment in Plantation Economies of the Third World. London: Oxford University Press.

--- 1975. Caribbean Economy: Dependence and Backwardness. Kingston, Jamaica: New Herald.

--- 1989. "Plantation Capitalism, Underdevelopment, and Transformation: With Special Reference to the Caribbean. In M. Martin and T. Kandal (eds.), studies of Development and Change in the Modern World. New York: Oxford University Press.

Bergesen, A. 1980. Studies of the Modern World-System. New York: Academic Press.

Berlinger, J. 1977. "Internal Migration: A Comparative Disciplinary View." In A. Brown and E. Newberger (eds.), Internal Migration: A Comparative Perspective. New York: Academic.

Bolingbroke, H. 1941. A Voyage to Demerary, 1799-1806. Edited by V. Roth. Georgetown. Daily Chronicle.

Bonilla, F. and Girling, R. 1973. Structures of Dependency. Stanford: Stanford University Press.

Brenner, R. 1977. "The origins of Capitalist Development: A Critique of neo-Smithian Marxism." New Left Review $104: 25-92$.

Bronkhurst, H. 1890. A Descriptive and Historical Geography of British Guiana and West India Islands. London.

Browett, J.G. 1980. "Development the Diffusionist Paradigm and Geography." Progress in Human Geography $4(1): 57-79$.

Burnham, F. 1970. A Destiny to Mould. London: Longman. 
Bush, B. 1990. Slave Women in Caribbean Society 1650-1838. Bloomington and Indianapolis: Indiana University Press.

Caporaso, J. 1979. "Dependence, Dependency, and Power in the Global System: A Structural and Behavioral Analysis." International organization $32(1): 13-43$.

Cardoso, F.H. 1972. "Dependency and Development in Latin America." New Left Review 74:83-95.

--- 1973. "Associated - Dependent Development: Theoretical and Practical Implications. In A. Stepan (ed.). Authoritarian Brazil: Origins, Policies, and Future. New Haven: Yale University Press.

Cardoso, F. and E. Faletto. 1979. Dependency and Development in Latin America. Berkeley: University of California Press.

Carnegie, C. (ed.). 1987. Afro-Caribbean Villages in Historical Perspective. Kingston: African-Caribbean Institute of Jamaica.

Castells, M. 1976. "Urban Sociology and Urban Politics: From a Critique to new Trends of Research." In J. Walton and L. H. Masotti (eds.), The City in Comparative Perspective: Cross-National Research and New Directions in Theory. New York: Halstead Press.

--- 1977. The Urban Question: A Marxist Approach. Cambridge, Mass.: MIT Press.

Chaichian, M. 1988. "The Effects of World Capitalist Economy on Urbanization in Egypt, 1800-1970." International Journal of Middle Eastern Studies 20:2343 .

Chase-Dunn, C. 1984. "Urbanization in the World-System; New Directions for Research." In M.P. Smith (ed.), Cities in Transformation. Beverly Hills: Sage.

Chirot, D. 1977. Social change in the Twentieth Century. New York: Harcourt Brace Jovanovitch.

Clarke, C.G. 1974. "Urbanization in the Caribbean." Geography $59(264): 223-32$.

Clementi, Sir Cecil. 1937. A Constitutional History of British Guiana. London. Macmillan.

Collymore, C. 1984. Bitter sugar and the Working People. 
Cohen, R.B. 1981. "The New International Division of Labor, Multinational Corporations and Urban Hierarchy." In Michael Dear and Allen Scott (eds.), Urbanization and Urban Planning in Capitalist Society. New York: Methuen.

Cooke, P. 1983. Theories of Planning and Spatial Development. London: Hutchinson.

Corbridge, S. 1986. Capitalist World Development: A Critique of Radical Development Geography. New York: Rowan and Littlefield.

Cornelius, W.A. 1975. "Introduction." In W.A. Cornelius and F.M. Trueblood (eds.), Urbanization and Inequality: The Political Economy of Urban and Rural Development in Latin America. Beverly Hills, Calif.: Sage.

Cross, M. 1979. Urbanization and Urban Growth in the Caribbean: An Essay on Social Change in Dependent Societies. Cambridge: Cambridge University Press.

Dalton, H. 1855. The History of British Guiana. London: Longman, Brown, Green \& Longman.

Daly, V. 1975. A Short History of the Guyanese People. London: Macmillan.

Danns, G. and L. Matthews. 1989. "Perspectives on the Development and Underdevelopment of Communities in Guyana: a Sociohistorical Analysis." In M. Martin and T. Kandal (eds.), studies of Development and Change in the Modern World. New York: Oxford University Press.

Davis, D. 1888. "The Records of British Guiana." Timheri 2.

Davis, D. 1987. "Religion and Development: Weber and East Asia Experience." In $M$. Weiner and $S$. Huntington (eds.), Understanding Political Development. Boston: Iittle, Brown.

De Caires, D. 1988. "Guyana After Burnham: A New Era? or is President Hoyte Trapped in the Skin of the old PNC?" Caribbean Affairs 1(1): 183-198.

Despres, L. 1967. Cultural Pluralism and Nationalist Politics in British Guiana. Chicago: Rand McNa:ly.

Dos Santos, T. 1970. "The Structure of Dependence." American Economic Review 60:235-246. 
Downer, A. 1982. "Settlements on the White Sands." In M. Thomas (ed.), The Caribbean Peoples and their Environment. London: CHEC.

Drakakis-Smith, D. 1981. Urbanisation, Housing, and the Development Process. London: Croom Helm.

---. 1986. (ed.), Urbanisation In The Developing World. London: Croom Helm.

Duvall, R. et. al. 1981. "A Formal Model of 'Dependencia Theory': Structure and Measurement." In R. Merritt and B. Russett (eds.), From National Development to Global Community. London: George Allen \& Unwin.

Economist Intelligence Unit. 1988. Country Profile. Guyana, . Barbados, windward \& Leeward Islands. London:EIU.

Ehrensaft, P. 1976. "Polarized Accumulation and the Theory of Economic Dependence: The Implications of South African Semi-Industrial Capitalism." In P. Gutkind and I. Wallerstein (eds.), The Political Economy of Contemporary Africa. Beverly Hills, Calif.: Sage.

Emmanuel, A. 1972. Unequal Exchange: A study of the Imperialism of Trade. New York: Monthly Review Press.

Evans, P. 1977. "Multinationals, state-owned Corporations, and the Transformation of Imperialism: A Brazilian Case Study." Economic Development and Cultural Change $26: 43-64$.

--. 1979a. "Beyond Center and Periphery: A Comment on the World System Approach to the Study of Development." Sociological Inquiry $49(4): 15-20$.

---. 1979b. Dependent Development: The Alliance of Multinational, state, and Local Capital in Brazil. Princeton: Princeton University Press.

Fainstein, N. and S. Fainstein. (eds.). 1982. Urban Policy Under Capitalism. Beverly Hills: Sage.

Farley, R. 1954. "The Rise of the Peasantry in British Guiana." Social and Econcmic studies 2 (1).

Forbes, D.K. 1984. The Geography of Underdevelopment: A Critical Survey. Baltimore: Johns Hopkins University Press. 
Foster-Carter, A. 1976. "From Rostow to Gunder Frank: Conflicting Paradigms in the Analysis of Underdevelopment." World Development 4(3):167-80.

Frank, A.G. 1966. "The Development of Underdevelopment." Monthly Review (September).

---1967. Capitalism and Underdevelopment in Latin America. New York: Monthly Review Press.

--- 1969. Latin America: Underdevelopment or Revolution. New York: Monthly Review Press.

--- 1972. Lumpenbourgeoisie, Lumpendevelopment: Dependence, class, and Politics in Latin America. New York: Monthly Review Press.

--- 1978a. Dependent Accumulation and Underdevelopment. New York: Monthly Review Press.

--- 1978b. World Accumulation, 1492-1789. New York: Monthly Review Press.

--- 1980: The Contemporary World Crisis. New. York: Monthly Review Press.

Friedmann, J. and G. Wolff. 1982. "World City Formation: An Agenda for Research and Action." International Journal of Urbain and Regional Research $6: 309-44$.

Friedmann, J. and R. Wulff. 1976. The Urban Transition. London: Butler and Tanner Ltd.

Galtung, J. 1971. "A Structural Theory of Imperialism." Journal of Peace Research $8(2)$.

Gilbert, A. 1980. "Planning for Urban Primacy and Large Cities in Latin America: A Critique of the Literature." Comparative Urban Research 8:105-16.

Gilbert, A. and J. Gugler. 1984. Cities, Poverty, and Development. Oxford: Oxford University Press.

Girvaın, N. 1972. Foreign Capital and Economic Underdevelopment in Jamaica. Kingston: University of the West Indies.

--- 1973. "Dependence and Underdevelopment in the New World and old." Social and Economic Studies $22(1)$.

Goslinga, C. 1985. The Dutch in the Caribbean and in the Guianas, 1680-1791. Dover, New Hampshire: Van Gorcum. 
Greene, J. 1976. "The Politics of Economic Planning in Guyana." Social and Economic Studies 23(2).

Grey, Earl. 1853. The Colonial Policy of Lord John Russell's Administration. London.

Gugler, J. and W. Flanagan. 1977. "On the Political Economy of Urbanization in the Third World: The Case of West Africa." International Journal of Urban and Regional Research 1:272-292.

Hagen, E.E. 1962. On the Theory of Social Change. Homewood, Ill.: Dorsey.

Hanley, E. 1975. "Rice, Politics and Development in Guyana" in oxaal, I. et. al. (eds.) Beyond the Sociology of Development. London: Routledge and Kegan Paul.

Hardoy, J. (ed.) . 1975. Urbanization in Latin America. New York: Anchor.

Harris, C. and J. Villiers. 1911. Storm van's Gravesande: The Rise of British Guiana. London: Hakluyt Society.

Harvey, D. 1973. Social Justice and the City. Baltimore: Johns Hopkins University.

---. 1978. "The Urban Process Under Capitalism: A Framework For Analysis." International Journal of Urban and Regional Research 2(1):101-131.

--- 1982. The Limits to Capital. Chicago: University of Chicago Press.

Hermassi, E. 1978. "Changing Patterns in Research on the Third World." Annual Review of Sociology 4:239-257.

Hintzen, P. 1989. The Costs of Regime Survival: Racial Mobilization, Elite Domination and Control of the State in Guyana and Trinidad. New York: Cambridge University Press.

Hope, K. 1985. Guyana: Politics and Development in an Emergent Socialist State. Oakville, Ontario: Mosaic.

Hopkins, T.K. and I. Wallerstein (eds.). 1980. Processes of the World System, Vol. 3. Political Economy of the World System Annuals. London: Sage.

Im Thurn, E. 1883. "Essequibo, Berbice and Demerara under the Dutch." Timheri II:33:80. 
Inkeles, A. and D. Smith. 1974. Becoming Modern. Cambridge, Mass.: Harvard University Press.

Jagan, C. 1966. The West on Trial: My Fight for Guyana's Freedom. New York: International Publishers.

Jefferson, 0. 1972. The Post-War Economic Development of Jamaica. Mona, Jamaica: University of the West Indies.

Jeffrey, H. and C. Baber. 1986. Guyana: Politics, Economics and Society: Beyond the Burnham Era. Boulder, Colo.: L. Rienner.

Jenkins, E. 1871. The Coolie, his Rights and Wrongs. London.

Jones, R. (ed.) . 1975. Essays on World Urbanization. London: George Philip and Son.

King, K. 1968. Land and People of Guyana. Oxford: University of oxford.

Kirke, H. 1898. Twenty-Five Years in British Guiana. London: S. Low, Marston \& Co.

Laclau, E. 1971. "Feudalism and Capitalism in Latin America." New Left Review 67:19-38.

Lakhan, V., D. Rawana and A. Lall. 1987. "Resource Allocation in Agriculture: The Guyana Experience." Canadian Journal. of Development Studies. 235:248.

"Landowner." 1853. British Guiana; Demerara After Fifteen Years of Freedom. London: T. Bosworth.

Latin American Bureau. 1984. Guyana: Fraudulent Revolution. London: Latin American Bureau.

Light, I. 1983. Cities in World Perspective. New York: Macmillan.

Lipton, M. 1977. Why Poor People stay Poor: A Study of Urban Bias in World Development. Cambridge: Harvard University Press.

Lojkine, J. 1976. "Contribution to a Marxist Theory of Capitalist Urbanization." In C. G. Pickvance (ed.), Urban Sociology: Critical Essays. New York: st. Martin's. 
Lubeck, P. and J. Walton. 1979. "Urban Class Conflict in Africa and Latin America: Comparative Analysis From a World systems Perspective." International Journal of Urban and Regional Research 4 (1):3-28.

Lutchman, H. 1974. From Colonialism to Co-operative Republic: Aspects of Political Development in Guyana. Rio Piedras, Puerto Rico: University of Puerto Rico.

Mabogunje, A.L. 1981. The Development Process: A Spatial Perspective. London: Hutchinson.

Mandle, J. 1973. The Plantation Economy: Population and Economic Change in Guyana, 1838-1960. Philedelphia: Temple University Press.

Mandel, E. 1975. Late Capitalism. New York: Humanities.

Martin, M. and T. Kandal (eds.). 1989. Studies of Development and Change in the Modern World. New York: oxford University Press.

Mcclelland, D.G. 1967. The Achieving Society. New York: Free Press.

McDonald, V. (ed.). 1980. Caribbean Issues of Emergence: Socio-economic and Political Perspectives. Washington, D.C.: University Press of America.

McGee, T.G. 1969. The Southeast Asian City. New York: Praeger.

---. 1971. "Catalysts or Cancers? The Role of Cities in Asian Society." In L. Jacobson and V. Prakash (ed.), Urbanization and National Development. Beverly Hills, Calif.: Sage.

--. 1973. Hawkers in Hong Kong: A Study of Policy and planning in a Third World City. Hong Kong: University of Hong Kong, Centre of Asian studies.

---. 1977. "Rural-Urban Mobility of South and Southeast Asia. Different Formulations... Different Answers." In J. Abu-Lughod and R. Hay, Jr. (eds.), Third World Urbanization. Chicago: Maaroufa Press.

Mehmet, 0. 1978. Economic Planning and Social Justice in Developing Countries. New York: St. Martin's Press.

Meillassoux, C. 1972. "From Reproduction to Production." Economy and Society 1:93-105. 
R. Merritt and B. Russett (eds.). 1981. From National Development to Global Community. London: George Allen \& Unwin.

Milliroux, M. 1843. Demerara, Transition From Slavery to Liberty. Tr. McFarlane. London.

Mingione, E. 1981. Social Conflict and the City. Oxford: Basil Blackwell.

Nath, D. 1970. A History of Indians in British Guiana. London: The Author.

--- 1975. A History of Guyana (Vols. I-III). London: The Author.

Nemeth, R. and D. Smith. 1985. "The Political Economy of Contrasting Urban Hierarchies in South Korea and the Philippines." 183-206 in M. Timberlake (ed.), Urbanization in the World Economy. New York: Academic Press.

Netscher, P. 1888. History of the Colonies, Essequibo, Demerara and Berbice. Tr. W.E. Roth (1929). Georgetown: Daily Chronicle.

Odle, M. 1976. The Evolution of Public Expenditure. The Case. of a Structurally Dependent Economy. Kingston: University of West Indies.

Palloix, C. 1975. "The Internationalisation of Capital and the circuit of Social Capital." In H. Radice (ed.), International Firms and Modern Imperialism. Harmondsworth: Penguin.

Palma, G. 1981. "Dependency: A Formal Theory of Underdevelopment or a Methodology for the Analysis of Concrete Situations of Underdevelopment?" In P. Streeten and R. Jolly (eds.), Recent Issues in World Development. Oxford: Pergamon Press.

Payne, G. 1982. "Analysis of a settlement - The Guyanese Situation - Melanie Damishana." In M. Thomas (ed.), The Caribbean Peoples and their Environment. London: CHEC.

Peek, P.: and G. Standing (eds.) : 1982. State Policies and Migration. Studies in Lat in America and the Caribbean. London: Croom Helm. 
Petras, J. and K. Trachte. 1979. "Liberal, Structural and Radical Approaches to Political Economy: An Assessment and an Alternative." Contemporary Crises 3:109-47.

Pickvance, C.G. 1978. "Competing Paradigms in Urban Sociology: Some Epistemological Issues." Comparative Urban Research $5(2,3): 20-27$.

---. 1983. "What is New About t the New Urban Sociology." Comparative Urban Research $9(2): 19-23$.

Pinckard, G. 1942. Letters From Guiana. Extracted from Notes on the West Indies and the Coast of Guiana. Edited by v. Roth. Georgetown: Daily Chronicle.

Portes, A. 1976. "The Economy lof Ecology of Urban Poverty." In A. Portes and J. Walton (eds.), Labor, Class, and the International system. New York: Academic Press.

---. 1979. "The Informal Sector and the World Economy: Notes on the structure of Subsidised Labour." IDS Bulletin 9:35-40.

--- 1985. "The Urban Informal Sector and the World Economy: Notes on the Structure of Subsidized Labor." In M. Timberlake (ed.), Urbanization in the World Economy. New York: Academic Press.

Portes, A. and J. Walton. 1976. Urban Latin America: The Political Condition from Above and Below. Austin: University of Texas.

-- 1981. Labor, Class and the International System. New York: Academic Press.

Potter, L. 1987. "Guyana: Cooperative Socialism, Planning and Reality. In D. Forbels and N. Thrift (eds.), The Socialist Third World. Urban Development and Territorial Planning. New York: Basil Blackwell.

Procter, I. 1982. "Some Political Economies of Urbanization and Suggestions for a Research Framework." International Journal of Urban and Regional Research 6(11):83-97.

Quijano, A. 1975. "The Urbanization of Latin American Society." In J. Hardoy (ed.), Urbanization in Latin America. New York: Anchor.

Ragatz, L. 1928. The Fall of the Planter Class in the British Caribbean, 1763-1833. London: Oxford University Press. 
Raleigh, Sir Walter. 1966. "Discoverie of Guyana." In New World (Guyana Independence Issue). Georgetown: New World Group Associates.

Reissman, L. 1964. Urban Process: Cities in Industrial Societies. Glencoe, I1l.: The Free Press.

Rey, P.-P. 1975. "The Lineage Mode of Production." Critique of Anthropology 3:27-79.

Rimmer, P.J and D.K. Forbes. 1982. "Underdevelopment Theory: A Geographical Review." Australian Geographer $15(4): 197-211$.

Roberts, B. 1978. Cities of Peasants. Beverly Hills, Calif.: Sage Publications.

Rodney, w. 1981. A History of the Guyanese Working People, 1881-1905. Baltimore: John Hopkins University Press.

Rodway, J. 1891-94. History of British Guiana, From the Year 1668 to the Present Time. ( 3 Vols.). Georgetown: J. Thomson.

---. 1912. Guiana: British, Dutch and French. London: T. Fisher, Unwin.

---. 1920. The Story of Georgetown. Georgetown: Argosy.

Rodway, J. and J. Stark. 1895. Stark's Guide-Book and History of British Guiana. Boston: Stark Publisher.

Rodway, J. and T. Watt. 1888. Chronological History of the Discovery and Settlement of Guiana, 1493-1796. Georgetown: Royal Gazette.

Rostow, W.W. 1962. The Stages of Economic Growth: A NonCommunist Manifesto. Massachusetts: Cambridge University Press.

Ruhoman, P. 1947. Centenary History of the East Indians in British Guiana, 1838-1938. Georgetown: Daily Chronicle.

Safa, H.I. 1982. "Introduction." In H.I. Safa (ed.), Towards a Political Economy of Urbanization in Third World Countries. New Delhi: Oxford University Press.

---. 1986. "Urbanization, the Informal Economy and state Policy in Latin America: A Dependency Perspective." Urban Anthropology $15(1-2): 135-63$. 
Salau, A. 1978. "The Political Economy of cities in Tropical Africa." Civilisations 28:281-290.

Sancho, T. 1966. Highlights of Guyanese History. Georgetown.

Santos, M. 1979. The Shared Space. London: Methuen.

Sayer, A. 1984. Method in Social Science: A Realist Approach. London: Hutchinson.

Schlesinger, A. 1965. A Thousand Days: John F. Kennedy in the White House. Boston: Houghton Mifflin.

Schomburgk, Richard. 1847. Travels in British Guiana 18401844. Tr. W. Roth. 1922. Georgetown: Daily Chronicle.

Schomburgk, Robert. 1840. A Description of British Guiana, Geographical and Statistical: Exhibiting its Resources and Capabilities, Together with the Present and Future Condition and Prospects of the colony. London: Simkin, Marshall. Reprinted, London: Frank Cass, 1970.

Schumpeter, J.A. 1934. The Theory of Economic Development. Cambridge, Mass.: Harvard University Press.

Scoble, J. 1840. Hill Coolies in British Guiana and Mauritius. London.

Seddon, D. (ed.) 1978. Relations of Production: Marxist Approaches to Economic Anthropology. London: Frank Cass.

Shahabuddeen, M. 1978. Constitutional Development in Guyana, 1621-1978. Georgetown: The Author.

---. 1983. From Plantocracy to Nationalisation: A Profile of Sugar in Guyana. Georgetown: University of Guyana.

Shivji, I. 1975. "Peasants and Class Alliances" Review of African Political Economy 3:10-20.

Simms, P. 1966. Trouble in Guyana: An Account of People, Personalities and Politics as they are in British Guiana. London: George Allen and Unwin.

Singh, C. 1988. Guyana: Politics in a Plantation Society. New York: Praeger.

Skocpol, T. 1977. "Wallerstein's World Capitalist System: A Theoretical and Historical Critique." American Journal of Sociology $82: 1075-1090$. 
Slater, D. 1974. "Contribution to a Critique of Development Geography.: Canadian Journal of African Studies $8(2): 325-354$.

--- 1978. "Towards a Political Economy of Urbanization in Peripheral Capitalist Societies." International Journal of Urban and Regional Research 2(1):26-52.

--- 1986. "Capitalism and Urbanisation at the Periphery: Problems of Interpretation and Analysis with Reference to Latin America." In D. Drakakis-Smith (ed.), Urbanisation in the Developing World. London: Croom Helm.

Smailes, A.E. 1975. "The Definition and Measurement of Urbanization." In R. Jones (ed.), Essays on World Urbanization. London: George Philip and Son.

Smith, C. 1985. "Class Relations and Urbanization in Guatemala: Toward an Alternative Theory of Urban Primacy." In M. Timberlake (ed.), Urbanization in the World Economy. New York: Academic Press.

Smith, D. 1985. "International Dependence and Urbanization in East Asia: Implications for Planning." Population Research and Policy Review 4:203-233.

Smith, D. and R. Nemeth. 1986. "Urban Development in Southeast Asia: A Historical-structural Analysis." 121-139 in D. Drakakis-Smith (ed.), Urbanisation in the Developing World. London: Croom Helm.

Smith, R. 1962. British Guiana. London: Oxford University Press.

So, A. 1986. "The Economic Success of Hong Kong: Insights from a World-System Perspective." Sociological Perspectives 29:241-258.

Soja, E. 1976. Spatial Inequality in Africa. Los Angeles: University of California.

Spinner, T. 1984. A Political and Social History of Guyana, 1945-1983. Boulder, Colo.: Westview.

St. Clair, T. 1947. A Soldier's Sojourn in British Guiana, 1806-1808. Edited by V. Roth. Georgetown: Daily Chronicle. 
Standing, G. 1979. "Socialism and Basic Needs in Guyana. In G. Standing and R. Szal, Poverty and Basic Needs: Evidence from Guyana and the Philippines. Geneva: ILO, World Development Programme.

Sukdeo, I. 1982. The Emergence of a Multiracial Society: The Sociology of Multiracism with Reference to Guyana. New York: Exposition Press.

Suret-Canale, J. 1971. French Colonialism in Tropical Africa, 1900-1945. London: Addison-Wesley.

Sylvan, D. et. al. 1983. "The Peripheral Economies. Penetration and Economic Distortion, 1970-1975." In W. Thompson (ed.), Contending Approaches to World System Analysis. Beverly Hills: Sage.

Taylor, J. 1979. From Modernization to Modes of Production. London: Macmillan.

Tennassee, P. 1982. Guyana: A Nation in Ruins. The puerto Rican Model Failed. Toronto: Guyanese Research \& Representation Services.

Terray, E. 1972. Marxism and "Primitive" Societies. New York: Monthly Review Press.

Thomas, C. 1982. "Guyana: The IMF-World Bank Group and the General Crisis." Social and Economic Studies. $31(4): 16-70$.

--- 1984. The Rise of the Authoritarian State in Peripheral Societies. New York: Monthly Review Press.

Thomas, M. (ed.). 1982. The Caribbean Peoples and their Environment. London: CHEC.

Thompson, A. 1987. Colonialism and Underdevelopment in Guyana. Bridgetown: Carib Research.

Thompson, W. (ed.). 1983. Contending Approaches to World System Analysis. Beverly Hills: Sage.

Tilly, C. 1984. Big structures, Large Processes, Huge Comparisons. New York: Russell Sage Publication.

Timberlake, M. (ed). 1985. Urbanization in the World-Economy. New York: Academic Press.

Todaro, M.P. 1985. Economic Development in the Third World. 3rd ed. New York: Longman. 
Valenzuela, J.S. and A. Valenzuela: 1978. "Modernization and Dependency." Comparative Politics 10:535-557.

Van Berkel, A. 1941. Adrian van Berkel's Travels in South America Between the Berbice and Essequibo Rivers and in Surinam, 1670-1689. Georgetown: Daily Chronicle.

Vapnarsky, C. 1975. "The Argentine System of Cities: Primacy and Rank-Size Rule." In J. Hardoy (ed.), Urbanization in Latin America. New York: Anchor.

Veness, W. 1867. El Dorado: or British Guiana as a Field for Colonisation.

Wallerstein, I. 1974. The Modern World-System I: Capitalist Agriculture and the origins of the European World-Economy in the sixteenth Century. New York: Academic Press.

--- 1976. "Semi-Peripheral Countries and the Contemporary World Crisis." Theory and Society 3:461-484.

--- 1977. "Rural Economy in Modern World Society." Studies in Comparative International Development 12:29-40.

---. 1979a. The Capitalist World-Economy. New York: Cambridge University Press.

---. 1980. The Modern World-System II: Mercantilism and the Consolidation of the European World-Economy, 1600-1750. New York: Academic Press.

--- 1984. The Politics of the World Economy. Cambridge: Cambridge University Press.

Wallerstein, I. and T. Hopkins. 1977. "Patterns of Development of the Modern World-System." Review $1: 111-145$.

Walters, P. 1985. "System of Cities and Urban Primacy: Problems of Definition and Measurement." In $M$. T'imberlake (ed.), Urbanization in the World Economy. New York: Anchor.

Walton, J. 1976. "Elites and the Politics of Development: A Comparative study of Four Cities." In A. Portes and J. Walton (eds.), Urban Latin America: The Political Condition from Above and Below. Austin: University of Texas. 
---. 1977. "Accumulation and Comparative Urban Systems: Theory and Some Tentative Contrasts of Latin America and Africa." Comparative Urban Research 5(1):5-18.

--. 1982. "The International Economy and Peripheral Urbanization." In N. Fainstein and S. Fainstein (eds.), Urban Policy Under Capitalism. Beverly Hills: Sage.

Weaver, J. and $K$. Jameson. 1981. Economic Development: Competing Paradigms. Washington, D.C.: University Press of America.

Webber, A. 1931. A Centenary History and Handbook of British Guiana. Georgetown: Argosy.

Williams, E. 1970. From Columbus to Castro: The History of the Caribbean, 1492-1969. London: Deutsch.

Williams, J. 1950. "The Development of the Cane Sugar Industry in British Guiana." Timheri 29.

Wolpe, H. 1980. "Introduction." In H. Wolpe (ed.), The Articuiation of Modes of Production, 1-43. London: Routledge and Kegan Paul.

Wong, S. 1988. "The Applicability of Asian Family Values to Other Sociocultural Settings." In P. Berger and $\mathrm{H}$. Hsiao (eds.), In Search of an East Asian Development Model. New Brunswick, NJ: Transaction.

Young, A. 1958. The Approaches to Local Self-Government in British Guiana. London: Longmans Green.

Zimbalist, A. 1980. "A Synthesis of Dependency and Class Analysis." Monthly Review 27-31.

DOCUMENTS AND REPORTS

Burnham, F. 1976. Address to the PNC. Georgetown: Ministry of Information.

Caricom. 1985. 1980-1981 Population Census of the Commonwealth Caribbean - Guyana (Vols. 1-3). Statistical Institute of Jamaica.

Central Transport Planning Unit. 1975. Transport Plan for Guyana.

CHPA. 1982. Georgetown Planning Area Development Plan Vols. 1-4. 
Danns, G. n.d. The Underground Economy and the state in Guyana - A Synopsis.

--- n.d. The New Elites in a silent Revolution.

Dick, C. 1984. Housing the Nation over Two Decades.

Extracts From Dutch Archives Made by the United States Commission on Boundary Between Venezuela and British Guiana. 1897. Washington, D.C.: United States Government Printing Office.

Francis, 0. 1966. Report on Survey of Manpower Requirements in the Labour Force, British Guiana. Georgetown: Government of Guyana.

Great Britain. Central office of Information. 1966. Guyana. London: H.M.S.O.

Great Britain. Colonial office.1949. Report of a Commission of Inquiry Into the Sugar Industry of British Guyana. London: H.M.S.O.

--- 1951. Annual Report on British Guiana. London: H.M.S.O.

--- 1960. Annual Report on British Guiana. London: H.M.S.O.

Guyana (British Guiana). 1862. Results of the Decennial Census of the Population, 7 April, 1861. Demerara: Royal Gazette Printery.

--- 1872. Results of the Decennial Census of the Population, 3 April, 1871. Demerara: The Creole Printery.

--- 1882. Results of the Decennial Census of the Population, 3 April, 1881. Demerara: Argosy office.

--- 1892. Report of the Results of the Population 1891. Georgetown.

--- 1912. Report on the Results of the Population, 1911. Georgetown: Argosy Company.

--- 1922. Report on the Results of the Population, 1921. Georgetown: Argosy Company.

--- 1932. Report on the Results of the Census of Population, 1931. Georgetown: Argosy Company. 
--- 1947. Ten Year Development Plan 1947-1956. Georgetown: Legislative Council.

--- 1949. Census of Population of the Colony of British Guiana, 1946. Kingston.

-- 1953. The constitution suspension ordered on oct. 8 , 1953. Bureau of Public Information.

--- 1954. Building Confidence. The Story of British Guiana in 1954. Government Information Services.

---. 1956. Development Programme 1956-1960. Georgetown: Legislative Council.

--. 1959. Development Programme 1960-1964. Georgetown: Legislative Council.

-- Population Census, 1960. Port of Spain: Central statistical office.

--- 1964. Annual Report Relating to External Trade. Georgetown: Government Printery.

---. 1966. Development Programme 1966-1972. Georgetown: Government Printery.

--- Guyana Population Census 1970.

--- 1973. Draft Second Development Plan 1972-1976. Georgetown: Ministry of Economic Development.

--- 1973. Guyana National Service State Paper.

--- 1974. A Decade of Progress. Georgetown.

--- 1976. Guyana Handbook.

-- 1980. Constitution of the Cooperative Republic of Guyana.

Guyana Heritage Society. 1986. A Guided Tour of Historic Georgetown. Georgetown.

Gyanchand. 1964. Annexure to the Report of the Three Year Plan 1964-65-66 for British Guiana, Volume of Basic statistics. 
Hoyte, D. 1980. Speech by Comrade Desmond Hoyte Minister of Economic Development and Cooperatives During Debate on the "Local Democratic organs Bill" in the National Assembly on Auqust 18,1980 . Georgetown: Ministry of Information.

IBRD. 1970. Current Economic Position and Prospects of Guyana. Vol. I. Main Report. Central America and Caribbean Department.

Jameson, K. and F. Bonello. 1978. A Macroeconomic Assessment of the Economy of Guyana.

King, K. 1973. A Great Future Together. Georgetown: Ministry of Information.

New World (Guyana Independence Issue). 1966. Georgetown: New World Group Associates.

PAHO. 1976. The National Food and Nutrition Survey of Guyana. Washington, D.C.

Report of the select Committee of the House of Commons on the commercial state of the West India Colonies. 1842 .

Report to His Excellency Henry Barkly. The Report of the Commissioners Appointed to Inquire Into and Report Upon the condition and Prospects of the colony of British Guiana. 1850.

Report on the Condition of the Colony of Bxitish Guiana During the Great European War, and on the Chief Local Problems Awaiting Solution. 1919. Georgetown: Argosy.

Report of the Economic Investigation Committee. 1930. Georgetown: Argosy.

Report of the Committee on Local Government Administration. 1931. Georgetown: Argosy.

Report of the Committee Appointed to Enquire Into the Sinking of Wells Under the Pure Water Supply Scheme. 1931. Georgetown: Argosy.

Report of the West India Royal Commission 1938-39. 1945. London: H.M.S.O.

Report of Constitutional Commission 1950-51. 1951. London: H.M.S.O. 
Supplementary Memorandum by the 108 (of 135) Lawyers opposed to the constitution (Amendment Bill, 1978) - In Answer to Certain Points Canvassed in support of the Aforesaid Bill and in Defence of the Attack Made on Lawyers. 1978 .

UNDP. 1972 . Background Paper. Country Programming 1972-1976. Georgetown: Cooperative Republic of Guyana.

World Economic Data. 1991. Santa Barbara, CA.: ABC-CLIO.

NEWSPAPERS

Barbados

Caribbean contact

England

The Guardian

The Sunday Times

Guyana

Berbice Gazette

Catholic Standard

Guyana chronicle

Official Gazette

Royal Gazette

Stabroek News

Sunday Graphic

The Mirror 
APPENDIX A

MAJOR GOALS/OBJECTIVES OF THE 1966-1972 DEVELOPMENT PROGRAM 
MAJOR GOALS/OBJECTIVES OF THE 1966-1972 DEVELOPMENT PROGRAM

1. To provide as many jobs as soon as possible.

2. To increase the productivity of labor through training.

3. To give each farmer sufficient land to maintain himself and his family and to assist him with improved credit and marketing facilities, information, and training.

4. To complete existing land development schemes, to start new ones, and to execute the first stages of the Mahaica/Mahaicony/Abary and Canje drainage and irrigation schemes.

5. To assist fishermen with building new trawlers and with improving their methods.

6. To develop new crops and industries so as to reduce dependence on sugar, rice, and bauxite and wherever possible to substitute local goods and foodstuffs for imports.

7. To carry out a thorough investigation and stocktaking of the resources by means of aerial mapping, hydroelectric power surveys, geological surveys, and surveys of water resources.

8. To ensure that the best possible use was made of the forests and that new forest industries were developed.

9. To ensure the rapid development of the mineral resources.

10. To assist with the rapid development of new industries by providing tax concessions, advice credit, training, etc.

11. To provide electricity for the villages and to increase urban electricity supplies so as to meet the needs of expanding industry.

12. To improve coastal roads, to build new roads into the interior, and to give access to land development schemes.

13. To cut the Berbice bar and channel so as to hasten economic development in that area.

14. To build a modern airport at Atkinson and to improve aviation facilities in the interior.

15. To provide complete telephone coverage of the 
country .

16. To provide equal educational opportunities for all regardless of race, religion, or social class.

17. To provide 30,000 places in all-age schools and 10,000 places in secondary schools and to train 300 teachers annually.

18. To start construction of buildings for the University of Guyana and to establish Technical Institutes in Essequibo and Berbice.

19. To organize, expand, and modernize the health services on a three-tier basis so as to provide a country-wide network of health centers and district hospitals and a new referral hospital in Georgetown.

20. To improve existing pure water supplies and to provide new supplies including supplies in the interior.

21. To assist in the provision of houses by helping with the development of land, the guarantee of loans, and self-help schemes.

22. To foster the self-help and co-op movements as main instruments of social and economic development.

23. To provide local government for the entire population.

24. To integrate Amerindians into the Guyanese community through a comprehensive program of social and economic development including the provision of schools, health facilities, training, community development schemes, and improvement of interior communications.

25. To maintain law and order and the security of the country through the expansion and training of the police force and the establishment of an adequate defense force.'

'Barker 1968, op. cit., pp. 12-14. 
APPENDIX B

MAJOR GOALS/OBJECTIVES OF THE 1980 GEORGETOWN PLAN 


\section{MAJOR GOALS/OBJECTIVES OF THE 1980 GEORGETOWN PLAN}

1. To indicate and facilitate measures needed to raise the economic performance of the city and standard of living of the people, especially the low and very low-income groups by the location and allocation of land for viable economic activities and increasing job opportunities.

2. To improve the quality of life provided by a suitable physical and social environment in which all people will have equitable opportunity to live, work, and enjoy recreation with the utmost safety, economy, convenience, and harmony.

3. To reserve or provide for all land needs, with the necessary infrastructure and facilities.

4. To ensure that built up acres within GPA are made compact and well structured so that transportation, public utilities and costs of journeys to work are minimized, and the performance of various urban activities are optimized.

5. To provide adequate housing, serviced with the necessary infrastructural services and facilities.

6. To provide for economical, efficient, and safe movement of vehicles and pedestrians by integration of the land uses with the transportation system, especially taking into account the needs of the low-income population and increasing fuel costs.

7. To provide employment areas with industries, offices, etc., so that they are accessible to worker housing; in energy efficient locations, environmentaliy suitable for development. These should be cost effective with infrastructure and compatible with surrounding areas.

8. To develop a thriving and attractive central area which caters for the needs of the catchment population with a system of neighborhood centers and markets economically viable and designed to serve the day-to-day needs of the population. Such neighborhood centers should be accessible to the people and located in areas where environmental quality and land-uses are not 
adversely affected.

9. To provide a system of community facilities, designed and located so as to balance convenience to users, social equity, cost efficiency, environmental quality, amenity and compatibility with surrounding land uses.

10. To ensure that adequate, economical and environmentally acceptable system of water supply, sewerage, Arainage, garbage collection and disposal, electricity, and telecommunication services are provided and located for the growing needs of the GPA at the appropriate time and according to appropriate standards.

11. To ensure that energy consumption is minimized by the judicious location of activities and adoption of appropriate energy saving measures including adoption of cost-effective public and personal transportation and public utility systems.

12. To provide a healthy environment through the adoption of suitable environmental control and protection measures, including legal measures and by the judicious disposition of land-uses and buildings.

13. To enhance the aesthetic values of the GPA by judicious urban design and by preserving the historical sites, monuments and buildings of architectural value.

14. To facilitate the development of a coordinated and unified administrative system which is provided with sufficient technical personnel, legal, and financial support to enable more plan preparation and development control and to implement development activities within GPA.'

'CHPA. 1982. Georgetown Planning Area Development Plan Vol. 4 , pp. 15-26. 